\title{
PRACE POLONISTYCZNE
}

\section{Akulturacja i jej literackie oblicza}

SERIA LXXII 

ŁÓDZKIE TOWARZYSTWO NAUKOWE

\section{PRACE POLONISTYCZNE}

AKULTURACJA I JEJ LITERACKIE OBLICZA

SERIA LXXII (2017)

ŁÓDŹ 2017

E 


\author{
REDAKCJA NAUKOWA WYDAWNICTW \\ ŁÓDZKIEGO TOWARZYSTWA NAUKOWEGO \\ Krystyna Czyżewska, Edward Karasiński, \\ Wanda M. Krajewska (redaktor naczelny), Henryk Piekarski, Jan Szymczak \\ 90-505 Łódź, ul. M. Skłodowskiej-Curie 11 \\ tel.: (42) 6655459 , faks: (42) 6655464 \\ sprzedaż wydawnictw tel.: (42) 6655448 http://sklep.ltn.lodz.pl \\ e-mail: biuro@ltn.lodz.pl http://www.ltn.lodz.pl
}

\title{
PRACE POLONISTYCZNE
}

\section{RADA NAUKOWA:}

Tomasz Bocheński (Uniwersytet Łódzki), Jacek Brzozowski (Uniwersytet Łódzki), Roman Dąbrowski (Uniwersytet Jagielloński), Danuta Künstler-Langner (Uniwersytet Mikołaja Kopernika), Krystyna Maksimowicz (Uniwersytet Gdański), Pierre Michel (Uniwersytet Angers, Francja), Anne-Marie Monluçon (Uniwersytet Grenoble-Alpes, Francja), Artur Timofiejew (Uniwersytet Marii Curie-Skłodowskiej), Dorota Walczak-Delanois (Uniwersytet w Brukseli, Belgia), Charles Zaremba (Uniwersytet Aix-Marseille, Aix-en-Provence, Francja)

KOLEGIUM REDAKCYJNE:

Redaktor naczelny: Marzena Karwowska, Zastępca redaktora naczelnego: Wiesław Pusz, Sekretarz Redakcji: Marta Szymor-Rólczak, Redaktorzy tematyczni: Tadeusz Błażejewski, Lidia Ignaczak, Marzena Karwowska, Wiesław Pusz, Maria Wichowa, Redaktorzy językowi: Kevin King (redaktor językowy, native speaker), Joanna Raźny, Marta Szymor-Rólczak, Katia Vandenborre (native speaker, Uniwersytet w Brukseli)

REDAKTOR NAUKOWY TOMU: Marzena Karwowska

REDAKTORZY JĘZYKOWI TOMU: Marta Szymor-Rólczak, Lidia Ignaczak, Marzena Karwowska, Kevin King (native speaker)

Czasopismo recenzowane w trybie double-blind review process. Szczegółowe informacje na temat procesu recenzowania oraz lista recenzentów współpracujących z czasopismem znajdują się na stronie internetowej „Prac Polonistycznych”.

OPRACOWANIE REDAKCYJNE I TECHNICZNE TOMU: Marta Szymor-Rólczak

Wydanie I

Copyright by Łódzkie Towarzystwo Naukowe, Łódź 2017

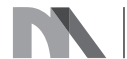

Ministerstwo Nauki

i Szkolnictwa Wyższego

Prace Polonistyczne - zadanie finansowane w ramach umowy 597/P-DUN/2017 ze środków Ministra Nauki i Szkolnictwa Wyższego przyznanych na działalność upowszechniającą naukę

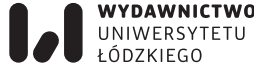

Wydano z pomocą finansową Dziekana Wydziału Filologicznego Uniwersytetu Łódzkiego oraz Zakładu Literatury Polskiej XX i XXI wieku Uniwersytetu Łódzkiego

Czasopismo jest indeksowane w bazie CEJSH, CEEOL, EBSCOhost, Index Copernicus, ERIH PLUS oraz znajduje się na ministerialnej liście punktowanych czasopism naukowych. Artykuły czasopisma w elektronicznej wersji są dostępne w bazach CEJSH, CEEOL, EBSCOhost, Index Copernicus, oraz na portalach ePNP.pl i IBUK

Przygotowanie czasopisma do digitalizacji: „PERFECT” Marek Szychowski, tel. (42) 2158346

ISSN: 0079-4791; e-ISSN: 2450-9353

DOI: $10.26485 / \mathrm{PP}$; DOI: $10.26485 / \mathrm{PP} / 2017 / 72$ 


\section{Spis treści}

OD REDAKCJI

9

\section{ROZPRAWY}

Marzena Karwowska

OBRAZY AKULTURACJI W „TAROCIE PARYSKIM”

Magdalena Lubelska-Renouf

AKULTURACJA? CZY INNY WEKTOR WSPÓŁCZESNOŚCI? KILKA SŁÓW

O REFLEKSJI CZESŁAWA MIŁOSZA

Stanistaw Jasionowicz

BYĆ OBCYM U SIEBIE? MARCIN ŚWIETLICKI I BARBARA GRUSZKA-ZYCH

WOBEC ZNAKÓW PRZYNALEŻNOŚCI

Dorota Samborska-Kukuć

ONIRYCZNA ANTYCYPACJA KORNELA FILIPOWICZA 59

Matgorzata Domagalska

ZBRODNIA W WIELOETNICZNYM LWOWIE. ŻYDZI W KRYMINAŁACH

MARKA KRAJEWSKIEGO

Maria Gotębiewska

PIERWIASTEK PAŁUBICZNY, KONSTRUKCJA I AKULTURACJA W „PAŁUBIE” KAROLA IRZYKOWSKIEGO

Marta Szymor-Rólczak

KONTEKSTY INKULTURACYJNE W „RĘKODZIELE FABRYKI SUKIENNEJ...”

WACŁAWA SIERAKOWSKIEGO

Laurent Béghin

«ALLER À LA POLOGNE, C'ÉTAIT ALLER À LA LUMIÈRE ». CLAUDE BACKVIS

ET LA MÉDIATION DE LA CULTURE POLONAISE EN BELGIQUE

FRANCOPHONE (1930-1960)

\section{PORÓWNANIA I KONTEKSTY. Z ZAGADNIEŃ KOMPARATYSTYKI}

Monika Bednarczuk

ŻYCIE I PISANIE (DLA) WSPÓLNOTY: KÄTHE SCHIRMACHER I STEFANIA

LAUDYN-CHRZANOWSKA MIĘDZY FEMINIZMEM A NACJONALIZMEM

Lidia Ignaczak

OD LES GOGUETTES DO KABARETÓW, CZYLI O ZALEŻNOŚCIACH

MIĘDZY POLSKA I FRANCUSKĄ PIOSENKĄ KABARETOWA

Z PRZEŁOMU XIX / XX WIEKU 
Cécile Bocianowski

MISE EN CORPS DES « GUEULES » DE « FERDYDURKE » : LE BALLET

GROTESQUE D'ANNA HOP À LA LUMIĖRE DE L'CEUVRE DE GOMBROWICZ ... 183

NA MARGINESACH LEKTUR

Piotr Bitos

TADEUSZ BOY-ZELENSKI : UNE CRITIQUE LITTÉRAIRE ENGAGÉE DANS

L'EXPLORATION DE LA VIE ET DE L'AUTONOMIE DE L'ART

NOTKI O AUTORACH 


\section{Content}

\section{ARTICLES}

Marzena Karwowska

IMAGES OF ACCULTURATION IN "THE PARISIAN TAROT"

Magdalena Lubelska-Renouf ACCULTURATION? OR ANOTHER VECTOR OF MODERNITY? REFLECTIONS

ON THE THOUGHTS OF CZESŁAW MIŁOSZ

Stanistaw Jasionowicz

NATIVE STRANGERS? MARCIN ŚWIETLICKI AND BARBARA GRUSZKA-ZYCH

FACING SIGNS OF BELONGING

Dorota Samborska-Kukuć

THE ONEIRIC ANTICIPATION OF KORNEL FILIPOWICZ

Matgorzata Domagalska

CRIME IN MULTIETHNIC LVOW. JEWS IN MAREK KRAJEWSKI'S

CRIME STORIES

Maria Gotębiewska

PAŁUBIC ELEMENT, CONSTRUCTION AND ACCULTURATION IN "PAŁUBA"

BY KAROL IRZYKOWSKI

Marta Szymor-Rólczak

INCULTURATORY CONTEXTS IN "REKODZIEŁO FABRYKI SUKIENNEY..."

BY WACŁAW SIERAKOWSKI

Laurent Béghin

"TO GO TO POLAND WAS TO GO TO THE LIGHT". CLAUDE BACKVIS

AND THE MEDIATION OF POLISH CULTURE IN FRENCH-SPEAKING BELGIUM (1930-1960)

COMPARISONS AND CONTEXTS. COMPARATIVE LITERATURE STUDIES

Monika Bednarczuk

THE SELF, COMMUNITY, AND WRITING: KÄTHE SCHIRMACHER

AND STEFANIA LAUDYN-CHRZANOWSKA BETWEEN FEMINISM

AND NATIONALISM

Lidia Ignaczak

FROM THE LES GOGUETTES TO CABARETS - ABOUT THE RELATIONSHIP BETWEEN A FRENCH AND POLISH CABARET SONG

IN THE YEARS 1881-1911 
Cécile Bocianowski

THE GROTESQUE BALLET OF ANNA HOP IN LIGHT OF GOMBROWICZ'S

WORKS

ON THE MARGINS OF READING

Piotr Bitos

TADEUSZ BOY-ŻELEŃSKI: A LITERARY CRITICISM COMMITTED

TO THE EXPLORATION OF LIFE AND THE AUTONOMY OF ART

THE AUTHORS' BIOGRAPHIES 


\section{OD REDAKCJI}

Siedemdziesiąty drugi rocznik „Prac Polonistycznych” jest realizacją międzynarodowego projektu naukowego poświęconego zagadnieniom akulturacyjnym.

Za punkt wyjścia rozważań przyjęte zostało antropologiczne rozumienie zjawiska akulturacji, analizowane dotąd w dyskursie humanistycznym na poziomie grupowym. W artykułach opublikowanych na łamach „Prac Polonistycznych" podjęta została przez badaczy próba przeniesienia tych analiz na poziom twórczego doświadczenia jednostkowego, skonkretyzowanego w tekstach literackich. Pragnęliśmy prześledzić artystyczne ujęcia fenomenu akulturacji, takie jak: strategie akulturacji na poziomie relacji międzyludzkich; migracja międzykulturowa, problem tożsamości u osób z doświadczeniem migracyjnym; dyfuzja kulturowa; hybrydyzacja i homogenizacja kultur.

Celem projektu był przegląd aktualnego stanu badań w obrębie tak aktualnej dziś tematyki akulturacyjnej oraz namysł nad kwestią funkcjonowania człowieka w systemie znaków kulturowych, które podlegają konwergencji. Pragnęliśmy zachęcić do dyskusji z diagnozą antropologiczną Maxa Schelera, według którego żyjemy w czasach zdominowanych (przy całej różnorodności i odrębności kultur) przez proces „zacierania się przeciwieństw”. Istotnym wydawało się również poszukiwanie odpowiedzi na pytanie, czy proces ten, nazwany przez Schelera zjawiskiem "łagodzenia napięć”, jest istotnie „nieuniknionym przeznaczeniem ludzkości” w dobie kulturowej globalizacji. 



\section{ROZPRAWY}



Prace Polonistyczne, seria LXXII, 2017

ISSN: 0079-4791; e-ISSN: 2450-9353

DOI: $10.26485 / \mathrm{PP} / 2017 / 72 / 1$

Marzena Karwowska

\section{OBRAZY AKULTURACJI W „TAROCIE PARYSKIM”}

\section{SŁOWA KLUCZOWE}

Manuela Gretkowska; Tarot paryski; akulturacja

Współczesny stan badań poświęconych akulturacji wskazuje, że jest to zagadnienie budzące $\mathrm{w}$ ostatnich latach coraz większe zainteresowanie naukowców (Rudmin 2003: 3-37, Berry 2006: 27-43, Berry 2003: 17-37, Kim, Abreu 2001: 394-424, Malewska-Peyre 2001). W latach trzydziestych dwudziestego wieku, za sprawą antropologów (Roberta Redfielda, Ralpha Lintona i Melville’a Herskovitsa) krystalizuje się i zostaje wprowadzone do dyskursu humanistycznego rozumienie fenomenu akulturacji ${ }^{1}$, definiowanej jako zespół zjawisk, które pojawiają się wówczas, gdy grupy jednostek z rożnych kultur wchodzą ze sobą w ciągły i bezpośredni kontakt, co powoduje późniejsze zmiany w oryginalnych wzorcach zachowań tych grup (Berry 2003: 17-37, Kim, Abreu 2001: 394-424). W latach późniejszych J.W. Berry, rozwijając badania nad akulturacją, opracował jej teoretyczny model, w którym wyróżnił strategie, jakie mogą przyjąć przedstawiciele kultury przyjmującej (zwanej też kulturą dominującą lub kulturą mainstream) oraz ludność napływowa. Wśród możliwych strategii akul-

Marzena Karwowska — dr hab., Zakład Literatury Polskiej XX i XXI wieku, Instytut Filologii Polskiej i Logopedii, Wydział Filologiczny, Uniwersytet Łódzki, ul. Pomorska 171/173, 90-236 Łódź; e-mail: marzenakarwowska@poczta.onet.pl

1 Termin akulturacja pojawił się w języku angielskim już w wieku XIX (Sam 2006: 11-27). 
turacyjnych gospodarzy wyróżnił: multikulturalizm ${ }^{2}$, dekulturację̧, melting pot $^{4}$ lub pressure cooker ${ }^{5}$, segregację․ Migranci, zdaniem Berry'ego, mogą przyjąć jedną z czterech strategii: separację , integrację $^{8}$, asymilację ${ }^{9}$ marginalizację ${ }^{10}$ (Berry 2003, 2006). Jako najkorzystniejsza strategia akulturacji wskazana została integracja, zmierzająca do powstania tożsamości dwukulturowej (Berry 2006). Idea tożsamości kulturowej w Europie Zachodniej stała się przedmiotem zainteresowania Johanna Gottfrieda Herdera już w wieku XVIII, według którego każda kultura ma charakter homogeniczny i narodowy. Żadne próby indywidualne czy też zbiorowe o charakterze akulturacyjnym nie są w stanie tego monolitu kultury naruszyć (Herder 1966), zaś wszelkie przejawy kontaktu międzykulturowego nazywa Herder zaledwie „zderzaniem się kultur” (Herder 1967: 45) ${ }^{11}$. Polemikę z tą paradygmatyczną dla wieku XIX i XX wizją kultury podjął Wolfgang Welsch, który zaproponował własną koncepcję transkulturowości w epoce globalizacji. Zdaniem Welscha kultury tradycyjne nie mają charakteru monolitycznego, przeciwnie, posiadają znamiona kultur mieszanych, a w perspektywie diachronicznej wszelkie ruchy artystyczne w Europie, uwikłane w sieć wzajemnych oddziaływań i zależności, zawsze w istocie swej były transkulturowe. Herderowska teoria kultury jest według Welscha już nieaktualna, nie objaśnia bowiem zjawisk nam współczesnych — w epoce globalizacji „transkulturowość istnieje nie tylko na makropoziomie całych społeczności, ale sięga mikropoziomu tożsamości indywidualnej" (Welsch 2004: 34). Badacz stawia fundamentalne dla zjawiska akulturacji pytanie: jakie elementy kulturowe odpowiadają za uformowanie tożsamości kulturowej jednostki? Uwarunkowania takie odnajduje w zjawisku konwergencji kultur $^{12}$, które nazywa „transkulturowym wymieszaniem” (Welsch 2004: 43).

${ }^{2}$ Próba włączenia ludności napływowej w krąg kultury dominującej, z jednoczesnym umożliwieniem zachowania jej własnej tożsamości.

${ }^{3}$ Strategia utrudniająca asymilację migrantów z nową kulturą oraz uniemożliwiająca zachowanie ich własnej tożsamości.

${ }^{4}$ Melting pot ('kociołek') — przedstawiciele kultury dominującej stwarzają migrantom warunki dogodne do asymilacji.

${ }_{5}$ Pressure cooker ('szybkowar') — przedstawiciele kultury mainstream oczekują od migrantów szybkiej asymilacji i porzucenia kultury pochodzenia.

${ }^{6}$ Uniemożliwienie wejścia migrantom w obręb kultury gospodarzy przy jednoczesnym przyzwoleniu na kultywowanie własnych tradycji.

7 Zachowanie własnej tożsamości przy całkowitym odrzuceniu kultury mainstream.

${ }^{8}$ Zachowanie własnej kultury przy jednoczesnym przejmowaniu elementów kultury gospodarzy.

9 Porzucenie własnej kultury i utożsamienie się z kulturą mainstream.

${ }^{10}$ Brak poczucia przynależności zarówno do kultury rodzimej, jak i nowej kultury.

${ }^{11}$ Cyt. za: Estetyka transkulturowa 2004: 33.

12 Welsch przywołuje na poparcie swojej tezy słowa Amy Gutmann: „Ludzkie tożsamości, a dotyczy to nie tylko zachodnich intelektualistów czy elit, zostały ukształtowane przez więcej niż jedną kulturę. Nie tylko społeczności, ale i ludzie są wielokulturowi” (Gutmann 1993: 183). 
Zjawisko to jest konsekwencją faktu, że style artystyczne, modele filozoficzne, estetyczne i kulturowe koegzystowały przez wieki historii: „ludzie przyzwyczajeni do korzystania z kilku modeli, nie boją się różnorodności, nie muszą przyswajać obcej mentalności, by zaakceptować współczesny pluralizm" (Welsch 2004: 43). Jednostkowa tożsamość transkulturowa jest przejawem naszej „obecności w świecie" (Welsch 2004: 38). Zanurzenie człowieka w tyglu wielokulturowym posiada walor epistemiczny. Heterogeniczne teksty kultury w epoce globalizacji niosą na poziomie doświadczenia podmiotowego obietnicę poznania, której człowiek współczesny nie możemy zignorować:

Zwabieni w ten sposób zbliżamy się do nich, obserwujemy je uważniej, badamy intensywniej. Znaczy to, że uznajemy je — niezależnie od dystansu czasu i przestrze$\mathrm{ni}$ - za aktualne wyzwania zawierające potencjał uczynienia nas bardziej czułymi, otwartymi na sprawy dotąd niezauważane, bardziej świadomymi, bardziej ludzkimi. Nie zamykamy ich więc w ramach historii, a raczej czujemy lub oczekujemy, że sami zostaniemy z ich pomocą uwolnieni od ograniczeń, uzyskując szerszy, bogatszy obraz świata, samych siebie. (Welsch 2004: 38)

Koncepcja podmiotowej tożsamości transkulturowej Wolfgang Welscha stanowi ważny zwrot $\mathrm{w}$ badaniach nad zjawiskiem akulturacji, które jako przedmiot zainteresowania psychologów, antropologów, socjologów, filozofów kultury analizowane bywa zazwyczaj na poziomie grupowym i otwiera drogę do przeniesienie tych badań na poziom twórczego doświadczenia jednostkowego, skonkretyzowanego w tekstach literackich.

Celem artykułu będzie zatem próba przyjrzenia się obrazowi akulturacji utrwalonemu w Tarocie paryskim Manueli Gretkowskiej ${ }^{13}$, a przedmiot zainteresowania stanowić będą artystyczne strategie wyrażenia omawianego fenomenu.

Gretkowska nazywana bywa skandalistką (Hurnik 2016: 135-151), prowokatorką (Krassowski 1996: 12), gorszycielką ${ }^{14}$, a jej proza pojawia się w kontekście takich zjawisk jak pornografia, literacka szmira (Lengren 1995: 112-114, Wiedemann 1993: 93-95, Jarosińska 1993: 49-50) ${ }^{15}$, tandeta, kicz

13 Tarot paryski został wydany po raz pierwszy w roku 1993 przez krakowską Oficynę Literacką. Wszystkie cytaty w artykule pochodzą z wydania Gretkowska 1999.

${ }^{14}$ Zdaniem Piotra Śliwińskiego w Polsce dominuje ciągle model kobiecości ugruntowany przez socrealizm: kobiety powściągliwej, nie oczekującej wiele od życia, natomiast Gretkowska „wchodzi w nie obsadzoną rolę prowokatorki, gorszycielki, kobiety ekscentrycznej i wolnej. Rolę feministyczno-ironiczną. Od dziesięcioleci nikt właściwie tej roli nie usiłował grać." (Czapliński, Śliwiński 1999: 216).

${ }^{15}$ D. Nowacki nazywa pisarstwo Gretkowskiej „lombardem kiczu” (Nowacki 1994: 60), sama Gretkowska nazywa często swoje powieści harlequinami dla intelektualistów. 
(Miszczak 2001: 145-189; 1998: 135-153) ${ }^{16}$, ale też podmiotowa nietożsamość (Czapliński 1995), desakralizacja narodowych mitów (Czyżak 2003: 253). Pisarka, wywodząca się z kręgu „bruLionu” (Klejnocki, Sosnowski 1996; Dunin Wąsowicz, Varga 1995) ${ }^{17}$ w roku 1988 wyjeżdża do Francji, gdzie studiuje antropologię w École des hautes études en sciences sociales. W roku 1991 wydaje, rekomendowaną przez Czesława Miłosza, swoją pierwszą powieść My zdies' emigranty (1991), rodzaj quasi-traktatu antropologicznego, w który winkrustowany został zapis doświadczeń emigracyjnych pokolenia Polaków urodzonych w latach sześćdziesiątych. Do wątków tych powraca Gretkowska i rozwija je już w formie artystycznej w powieści Tarot paryski z roku 1993.

Problematyka akulturacyjna w strukturze powieści przypomina solenoid, autorka powraca do niej wielokrotnie na różnych poziomach organizacji tekstu. Pierwszym z takich poziomów jest multikulturowość bohaterów. Gretkowska zaludnia swoją powieść reprezentantami rożnych narodowości, których umieszcza w zamkniętej przestrzeni paryskiej kamienicy. Dla Charlotty, Polki z pochodzenia, jej męża Xaviera — „Francuza z Francuzów” (Gretkowska 1999: 50) oraz ich lokatorów: filozofa z Polski - Michała i szwajcarskiego stypendysty Thomasa owo zamknięte orbis interior, symbolizujące w sposób aż nazbyt oczywisty cały wielokulturowy Paryż, ma charakter ambiwalentny, raz jest przestrzenią izolacji, innym razem pretekstem do tego, aby „być razem” (Gretkowska 1999: 68).

Akcję swojej powieści umieszcza Gretkowska na Montmartre, w dzielnicy stanowiącej stolicę wielonarodowej cyganerii. Konstruując chronotop Gretkowska dzieli przestrzeń na szereg obszarów ograniczonych ścianami i zamkniętych drzwiami, oprócz mieszkania-pracowni Xaviera na Montmartre są to paryskie kawiarnie. Jedną z nich jest słowiańska restauracyjka na rue Pavée, do której Charlotta zwabia często swoją francuską przyjaciółkę Gabrielę. Zamiast opisywać sytuację psychologiczną polskiego emigranta w Paryżu Gretkowska przewrotnie gra konwencją swój-obcy i wprowadza chwyt à rebours stawiając prowokacyjnie „Francuzkę z Francuza” w sytuacji etrangera:

Uwielbiam Cię w tej knajpie, bo nie rozumiesz ani słowa. Możesz zamówić herbatę i jesteś bezradna, słysząc, jak kelnerka rozmawia po polsku, rosyjsku. Chcę żebyś chociaż tutaj była mniej u siebie. (Gretkowska 1999: 34)

W restauracji na rue Pavée transfer kulturowy nie zachodzi: dla Gabrieli Polacy spotykający się w kawiarni są niezrozumiali („Siedzicie w zatęchłej piwnicy, mówicie szeleszczącymi narzeczami" - Gretkowska 1999: 35). Przeciwnie, bohaterki

${ }^{16}$ Anna Mizerka interpretuje kicz w pisarstwie Gretkowskiej jako zabieg demitologizacyjny, szczególnie w odniesieniu do mitu kobieta-matka-Polka (Mizerka: 2006).

${ }^{17}$ Nazwa pisma bywa zapisywana trojako: „bruLion”, „brulion” lub „bRULION”. 
antagonizując kultury, których są reprezentantkami, podejmują kwestie tożsamościowe: według Charlotty Słowianie są dla innych nacji „nieprzetłumaczalni”, Gabriela kończy utarczkę słowną prośbą: „Pomówmy o Francuzach” (Gretkowska 1999: 35).

Druga z kawiarni, Le Mazet na Bulwarze Saint Germain, do której Gretkowska chętnie przenosi akcję swojej powieści, jest na zasadzie kontrastu przestrzenią w pełni multikulturową. W jej obrazowaniu pojawia się typowa dla powieści Gretkowskiej ambiwalencja waloryzacji. Widoczna jest ona we współwystępowaniu semantyki wspólnotowej (wśród galerii postaci koegzystujących w przyjacielskiej atmosferze w Le Mazet znajdziemy Bryana — amerykańskiego bluesmana, mnicha tybetańskiego w towarzystwie asystenta, Francuza „w powiewnej pomarańczowej szacie" (Gretkowska 1999: 102), chłopaka o południowej urodzie mówiącego po hiszpańsku) i obrazów rozpadu, schyłku tej wspólnoty (Thomas powołując się na etymologię arabską i hebrajską („mot, mat”) tłumaczy słowo Mazet jako „martwy” (Gretkowska 1999: 162).

Należałoby zadać sobie pytanie, jaką funkcję w utworze Gretkowskiej pełni konstrukcja przestrzeni jako obszaru zamknięcia, czy jest to symbol izolacji i samotności bohaterów, czy też przeciwnie synonim społecznej autarkii, samowystarczalności multikulturowej społeczności żyjącej w mieszkaniu Charlotty na Montmartre, i doskonale zorganizowanej, z własną ekonomią, językiem, organizacją dnia - Roland Barthes tego typu strukturę przestrzeni zamkniętej utożsamia ze szczęściem (Barthes 1996: 21).

Gretkowska nie daje tu jednoznacznych odpowiedzi, raczej nieustannie prowokuje, uchylając się od prostych diagnoz.

I tak, dla przeciwwagi, jednoznacznie pozytywnie waloryzuje multikulturowość Paryża w sekwencji scen obrazujących symbiozę kultur za pomocą symboli jednoczących, jakimi są paryski „zaułek-piramida” czy „koszerne beaujolais”: „przed Beaubourgiem, jak co dzień, Indianie w ponczach i melonikach śpiewają o kondorach. [...] Wspinając się po śliskim bruku, mijam siedzących w kucki Indian i stroma ulica staje się w rytm ich muzyki ścianą meksykańskiej piramidy" (Gretkowska 1999: 30). W mijanym bistro Charlotta wypija kieliszek beaujolais w towarzystwie przypadkowo poznanego lubawicza — członka ortodoksyjnej sekty żydowskiej. Podobny wymiar symboliczny ma postać „Monsieur Wonga” (Gretkowska 1999: 69), trwale wpisanego w pejzaż Paryża właściciela chińskiej restauracji w XIII dzielnicy, który wśród dymu kadzideł palących się przed figurką Buddy karmi swoich europejskich gości soją, przezroczystym makaronem i azjatyckimi konserwami z mięsa łabędzi czy też opis wystawy sklepowej oglądanej przez Charlottę w galerii handlowej: „Kilkanaście lalek i misiów przebranych w karnawałowe stroje weneckie tańczyło do muzyki Vivaldiego. - W tamtym 
roku były stroje mauretańskie — przypomniałam sobie świąteczne dekoracje Lafayette" (Gretkowska 1999: 132).

Ta coincidentia oppositorum bliska jest diagnozom kultury zaproponowanym przez André Malraux. Malraux, antropolog znany bardziej jako pisarz i minister kultury w rządzie de Gaulle'a, w książce L'Intemporel. La metamorphose des Dieux (Malraux 1976) zajmuje się kwestią intensywnego przenikania do kultury symbolicznej Europy fenomenów kultur, które nazywa egzotycznymi (azjatyckiej i afrykańskiej), określając ten proces mianem rewolucji kopernikańskiej. Taka transmisja kultur prowadzi do powstania ponadczasowego zjawiska estetycznego, rozpoczynającego światowy dialog kultur „poza historią”. Ten nieuchronny nowy fenomen, nazwany przez Malraux Sztuką Świata, zmieni jego zdaniem istotę kultury europejskiej. Dla Europejczyka oznacza to „zdjęcie katarakty z oczu” (Malraux 1985: 256), to jest przyjęcie nowej transkulturowej postawy estetycznej, opartej na metamorfozie widzenia: „Nasze widzenie poprzedza pilotujace spojrzenie, które proponuje sens, jaki mamy mu nadać" (Malraux 1985: 245) oraz na otwarciu się na zjawiska funkcjonujące poza momentem historycznym i paradygmatem geograficznym: „Metamorfoza, której ulega nasze obcowanie ze sztuką, jest jedyną formą życia dzieła sztuki w czasie” (Malraux 1985: 339).

W Tarocie paryskim Gretkowskiej owa wielokulturowość bywa jednak równie często waloryzowana negatywnie i utożsamiana z procesem degradacji kultury wysokiej starego kontynentu: „Żyjąc w Paryżu, można podróżować po rożnych światach, greckim, chińskim, włoskim, wystarczy przejść z jednej ulicy czy knajpy do drugiej. Egzotyczne światy, pstrokate, tandetne" (Gretkowska 1999: 134). Waloryzacja negatywna multikulturowości pojawia się też w konstrukcji głównej postaci powieściowej, wyobcowanie Charlotty i jej problemy z tożsamością zostały zaprezentowane za pomocą symboliki wina, które tutaj jawi się jako kod kulturowy czytelny tylko dla „Francuzów z Francuzów”:

— Thomas, do camemberta podaje się bordeaux, do każdego sera pasuje inne wino przekonywał Xavier. [...] — Charlotta do camemberta pije canelli. — Charlotta nie może być żadnym argumentem. Ona jest pół Polką, pół Francuzką, wszystko w niej jest pomieszane. (Gretkowska 1999: 134)

Brak umiejętności deszyfracji kodów kulturowych powoduje, że Charlotta jest postrzegana jako obca nawet przez konsjerżkę, Portugalkę:

- Bonsoir madame Azzolina, ładnie pachnie Pani sprzątanie.

- Bonsoir, bonsoir madame. Świąteczne sprzątanie.

- Do świąt jeszcze miesiąc.

— Jakby pani nie w Paryżu rodzona. Wystawiają choinki w Lafayette koło Opery, znaczy się czas sprzątać na Boże Narodzenie. (Gretkowska 1999: 89) 
Ważnym forum wypowiedzi na tematy akulturacyjne w Tarocie paryskim jest warstwa dialogowa powieści. Bohaterowie w swoich dyskusjach, pomimo różnic narodowościowych, wykorzystują intelektualne kody spójności kulturowej. Gretkowska proponuje na tym poziomie wędrówkę w czasie przez historię i teksty kultury, czytelne dla wszystkich multikulturowych bohaterów: od Orygenesa, Tertuliana, Kanta, Kartezjusza, Schopenhauera, Husserla, Dostojewskiego, Derridę, aż po egipskiego Horusa, kabałę i symbolikę Tarota. Jednocześnie jednak autorka wprowadza do narracji ironiczny dystans wobec akademickiej sofistyki bohaterów, widoczny w opisie ich pseudointelektualnych dyskusji. Manipulacja symboliką Tarota czy symboliką filmu Lyncha w celu uzasadnienia dowolnie postawionej tezy, to kolejne odsłony artystycznej prowokacji. Ma ona prowadzić do dekonstrukcji kodów spójności kulturowej, które, wydawałoby się, jest zdolny rozszyfrować człowiek pojmowany jako res cogitans, bez względu na przynależność narodową. Nawiązaniem aż nazbyt czytelnym do kartezjańskiej koncepcji antropologicznej, apoteozującej potęgę intelektu jako struktury transcendującej ograniczenia historyczno-geograficzne, jest przyniesiona z wykopalisk archeologicznych czaszka przechowywana w mieszkaniu Charlotty w lodówce zamiast jedzenia. Owa parodystyczna dekonstrukcja człowieka kartezjańskiego stanowi postmodernistyczną grę z tradycją. Za pomocą strategii ponowoczesnych Gretkowska rozbija spójność kodów kulturowych, dokonując ich desakralizacji (buty świętego w instalacji rzeźbiarskiej Xaviera śmierdzą, wino mszalne staje się tanim winem w kawiarni Le Mazet), inkrustuje w tkaninę europejskiej kultury wysokiej (akademickie rozmowy filozoficzne bohaterów, interpretacja przesłania obrazu Rembrandta Żdowska narzeczona, stypendium Fundacji Kultury) kicz, pornografię, pedofilię. Gretkowska nieustannie prowadzi z tekstami kultury intertekstualny dialog, scena defloracji dziesięcioletniej kuzynki przez Xaviera, wywołuje na dalszych kartach powieści asocjację z prozą Dostojewskiego i postacią Stawrogina oraz z aktami Modiglianiego, pijany Sasza peroruje na temat „antyhistorycznej kobiecości”, uwiecznionej na obrazie Rembrandta, tonąc spojrzeniem w silikonowym biuście Gabrieli („zostaną pięknie jędrne do końca życia pozagrobowego” — Gretkowska 1999: 92), czaszka przyniesiona przez Thomasa z wykopalisk archeologicznych kompromituje kulturową symbolikę dramatu szekspirowskiego:

Zastanawiamy się, gdzie ją położyć.

— Może na stole, obok świecy — zaproponował Szwajcar.

— Mein Gott, co za kicz — westchnął Xavier. (Gretkowska 1999: 72)

Gretkowska chętnie wykorzystuje w prezentacji poziomów akulturacji stereotypy narodowościowe: Charlotta co prawda nie zachowała polskiego imienia, ponieważ przeszła ryt inicjacyjny wejścia w obcą kulturę zapośredniczony 
przez małżeństwo z Xavierem ${ }^{18}$, ale pozostała ciągle dziewczyną ze słowiańskim, złotym warkoczem. Wielokulturowi mieszkańcy pracowni na Montmartre jedzą włoskie spaghetti, polski schabowy i rosół, francuskie foie gras, bagietkę i camembert popijając francuskim bordeaux lub włoskim canelli, a tym co ich jednoczy jest wspólny niedostatek, międzynarodowy język biedy, najdosadniej wyrażony w obrazie wspólnego poszukiwania na śmietnikach XVI dzielnicy sprzętów do mieszkania Charlotty. Ironia („Coraz rzadziej będziemy jedli — powiedziałam, tasując karty. To nie wróżba, po prostu kończy się forsa” — Gretkowska 1999: 61) i dystans to kolejna prowokacyjno-gorzka odsłona transferu kulturowego.

W Tarocie paryskim Gretkowska przekracza granice, podejmuje grę ze stereotypami, łamie tabu, desakralizuje mity. Desakralizuje romantyczny mit miłości małżeńskiej (zamiast niej proponuje czytelnikowi sceny seksu małżeńskiego $\mathrm{w}$ bramie ${ }^{19}$ czy polemikę z prokreacyjnym charakterem związku małżeńskiego para gejów z Londynu wręcza francuskim przyjaciołom kolczyki wykonane z martwych płodów), mit dziewictwa zastępuje incestem i pedofilią (dziesięcioletnia Odille przeżywa swoją inicjację seksualną z pijanym kuzynem).

Bohaterowie powieści Gretkowskiej na sposób Schelerowskii ${ }^{20}$ zacierają w swoim życiu granice między świętością i profanicznością — mit świętego Mikołaja zostaje wyparty przez hazard — homo religiosus ustępuje miejsca homo ludens:

Wuj przegrywa u Xaviera corocznie pięćset franków. Dawniej dawał swojemu ulubionemu bratankowi na Boże Narodzenie parę setek za pośrednictwem świętego Mikołaja. [...] Kiedy Xavier skończył szesnaście lat, świętego Mikołaja zastąpiła ruletka. (Gretkowska 1999: 122)

Xavier, dawny ministrant z Notre Dame, podczas przygotowanej przez Charlottę polskiej kolacji wigilijnej z udziałem stypendystki z Korei Południowej, kpiarsko desakralizuje zakorzenioną w tradycji symbolikę chrześcijańską:

Zjedliśmy dwanaście dań. Czang była bardzo wzruszona, jej pierwsze święta poza domem. Niemal z nabożeństwem nakładała sobie na talerz kawałki karpia, pierogi. Wstaliśmy od stołu po północy, Czang podziękowała za zaproszenie, ukłoniła się kilka razy. Zaczerwieniona z emocji [...] odważyła się cieniutkim głosem poprosić nas o jedno ździebełko siana spod obrusu — zawiezie je swojej rodzinie w Seulu. Oprawią

${ }^{18} \mathrm{~W}$ misteriach inicjacyjnych adept umierał symbolicznie, aby otrzymać nowe życie (co wiązało się często ze zmianą imienia) i zostać przyjętym przez wspólnotę (szerzej na ten temat, por. Vierne 2000).

19 „Na rue des Martyres nikogo nie zdziwi, że klęczę zasłonięta twoim rozpiętym płaszczem. Nocni przechodnie pomyślą z politowaniem, że nie stać nas na hotel. Karmię się tobą mój wielosmakowy kochanku. Masz dzisiaj smak czosnku i antybiotyków" - Gretkowska 1999: 70).

${ }^{20}$ Zdaniem Maxa Schelera żyjemy w epoce „zacierania się przeciwieństw” (Scheler 1987: 191-237). 
źdźbło w ramki za szkłem, siano ze żłobka Jezusa. Gabriela, chichocząc zasłoniła się puderniczką, niby poprawiała makijaż, Xavier wyskoczył z łóżka, capnął garść siana i wcisnął jej do ręki — Czang, bierz, dla całej parafii. (Gretkowska 1999: 125)

W podobnej funkcji demitologizacji i dekonstrukcji kulturowych symboli wprowadziła do swojej powieści Gretkowska postać kloszarda z metra paryskiego w roli współczesnej personifikacji Ducha Świąt: „Kloszard poobwieszany bombkami, z wyrysowaną gwiazdą na czole, owinięty złotym łańcuchem po czekoladkach zastępuje drogę w wąskich przejściach, prosząc o datki dla bożonarodzeniowej choinki" (Gretkowska 1999: 126).

W opisie sceny rozmowy Charlotty i Michała w kawiarni Gretkowska symultanicznie prowadzi dwa plany prezentacji: pierwszy z nich przedstawia dialog bohaterów na temat kontemplacji zakonników w klasztorze Cordes-sur-ciel, świętości modlitwy, scenę łamania chleba i zanurzania go w winie, drugi plan prezentacji buduje podstarzała Juliette Greco, kelnerka rozlewająca za kontuarem tanie beaujolais, wyślizgany drewniany stół oblepiony brudnymi filiżankami i talerzami pełnymi petów, sparaliżowany kloszard podnoszący w zębach szklankę i wysysający z niej resztki wina, „skrzypnięcie drzwi kibla popychanych przeciagiem, dyskretna odsłona popstrzonego klozetu, moment kontemplacji” (Gretkowska 1999: 137).

W konstrukcji epizodycznej postaci powieściowej, Michela, Gretkowska desakralizuje symbolikę lucyferyczną. Postmodernistyczna transformacja tego współczesnego wcielenia lucyferyzmu przybiera formę groteski, jedynymi przejawami infernalnych mocy Michela są pomalowane czarnym lakierem paznokcie i kolczyki wykonane z ludzkich płodów zanurzonych w żywicy. Gretkowska ośmiesza wszystkie lucyferyczne gesty i atrybuty swojego powieściowego bohatera, które stają się na kartach Tarota paryskiego zaledwie rekwizytami w kiczowatej teatralizacji życia — ciężar kolczyków deformuje uszy Michela, czarne paznokcie i srebrne pierścienie na palcach stanowią elementy popkulturowej stylizacji deathmetalowej.

Jaki zatem obraz akulturacji wyłania się ostatecznie z ponowoczesnego chaosu obrazów składających się na powieść Gretkowskiej?

Paryż pojmowany metonimicznie jest wielką metaforą strategii akulturacyjnej, która bliska jest multikulturalizmowi, przybysze jednak, pomimo okoliczności sprzyjających — zdawałoby się — asymilacji („Paryż jest pretekstem, żebyśmy byli razem” — Gretkowska 1999: 68), wpisują się swoimi postawami w schemat marginalizacji, wiodąc raczej życie „skazanych na Paryż”, (Gretkowska 1999: 126). Bohaterowie powieści Gretkowskiej poszukując własnej tożsamości kulturowej, doświadczają uczucia egzystencjalnej obcości, heideggerowskiego 
Geworfenheit. Thomas, szwajcarski doktorant o „wygasłych oczach”, jest w istocie „niedostępny”: „Niby jest z nami w każdy wieczór, opowiada zabawne historyjki, włóczy się z Michałem po muzeach i bibliotekach, zajmuje Xaviera obsesją mówienia o niczym, a tak naprawdę wcale z nami nie jest. Siedzi przy stole, jakby siedział w poczekalni dworcowej" (Gretkowska 1999: 91). Polski emigrant, Michał, swoją próbę asymilacji wieńczy samobójstwem w paryskim mieszkaniu Xaviera:

Posłuchaj — powie przed śmiercią Charlotcie — „Śmierć”, „śmierci”, najbliższe tym słowom jest „śmierdzi”, jeszcze nie zdążysz umrzeć, a już śmierdzisz. We francuskim jest poetyckie, dźwięczne la mort, brzmi niemal jak l'amour. Nie chcę umierać w języku polskim, moja ostatnia wola, je ne voudrais pas mourir dans la langue polonaise. (Gretkowska 1999: 136)

Ta ambiwalencja postaw widoczna na styku akulturacji i poszukiwania tożsamości indywidualnej oraz grupowej, narodowościowej bliska jest figurze mitycznej Persefony, która od momentu skosztowania owocu granatu wszędzie jest u siebie i jednocześnie nigdzie nie jest u siebie, jak Charlotta, pół Francuzka ze słowiańskim złotym warkoczem, niestosownie pijąca do camemberta słodkie canelli. Dlatego też Charlotta, zawieszona między próbą integracji i marginalizacją kulturową, w chwili rozpaczy komunikuje mężowi swój ból w języku przodków. Reakcja Xaviera tę marginalizację tylko pogłębia: „Prosisz, żebym się uspokoiła i mówiła po francusku, bo nic nie rozumiesz" (Gretkowska 1999: 70).

\section{BIBLIOGRAFIA}

Barthes Roland. 1996. Sades, Fourier, Loyola. Przeł. Renata Lis. Warszawa: KR.

Berry John W. 2006. Contexts of Acculturation. W: The Cambridge Handbook of Acculturation Psychology. Red. J.W. Berry, David L. Sam. Cambridge: Cambridge University Press. S. 27-43.

Berry John W. 2003. Conceptual Approches to Acculturation. W: Acculturation. Advances in Theory, Measurement and Applied Research. Red. Kevin M. Chun, Pamela B. Organista, Marin Washington: American Psychological Associacion. S. 17-37.

Czapliński Przemysław. Sztuka prozatorska Manueli Gretkowskiej. „Kresy” 1995, nr 8.

Czapliński Przemysław, Śliwiński Piotr. 1999. Kontrapunkt. Rozmowy o książkach. Poznań: Obserwator. S. 216.

Czyżak Agnieszka. „Polka” w szponach natury. „Poznańskie Studia Polonistyczne” 2003, nr 10. S. 253.

Dunin Wąsowicz Paweł, Varga Krzysztof. 1995. Parnas-Bis. Stownik literatury polskiej urodzonej po 1960 roku, Warszawa: Lampa i Iskra Boża. 
Herder Johann Gottfried. 1966. Outlines of a philosophy of the History of Man. New York: Bergman Publishers.

Herder Johann Gottfried. 1967. Auch eine Philosophie der Geschichte zur Bildung der Menschheit, Frankfurt/Main: Suhrkamp.

Gretkowska Manuela. 1999. Tarot paryski. Wyd. III, poprawione. Warszawa: W.A.B.

Gutmann Amy.1993. The Challenge of Multiculturalism in Political Ethics „Philosophy \&Public Affairs", 22, nr 3 (1993). S. 171-206.

Hurnik Janusz. 2016. Manuela Gretkowska: skandalistka czy mieszczka? W: Antropologia kultury mieszczańskiej. Red. Joanna Ławnikowska-Koper i Lucyna Rożek. Częstochowa: Akademia im. Jana Długosza. S. 135-151.

Jarosińska Izabela. Gdzie jest ten emigracyjny skowyt. Recenzja Tarota paryskiego. „Nowe Książki” 1993, nr 12. S. 49-50.

Kim B.S., Abreu J.M. 2001. Acculturation Measurement. Theory, Current Instruments, and Future Directions. W: Handbook of Multicultural Counseling. Red. J.G. Ponterotto, J.M. Casas, L.A. Suzuki, C.M. Alexander. London: SAGE Publications. S. 394-424.

Klejnocki Jarosław, Sosnowski Jerzy. 1996. Chwilowe zawieszenie broni. O twórczości tzw. pokolenia „bruLionu” (1986-1996), Warszawa: Sic!

Krassowski Maciej. Gretkowska jako prowokacja. „Wiadomości Kulturalne” 1996, nr 26. S. 12 .

Lengren Magda. Proza w btazeńskiej czapce. „Twórczość” 1995, nr 1. S. 112-114.

Malewska-Peyre Hanna. 2001. Swojskość i obcość. O akulturacji imigrantów w Polsce. Warszawa: Wydawnictwo Instytutu Psychologii PAN.

Malraux André. 1976. L'Intemporel. La metamorphose des Dieux. T. 3. Paris: Edition Gallimard.

Malraux André. 2000. Ponadczasowe. Przemiany bogów. Przeł. Jerzy Lisowski. T. 3. Warszawa: Krajowa Agencja Wydawnicza.

Miszczak Magdalena. Kicz i parodia w prozie Manueli Gretkowskiej. Czym jest; Jak jest; Po co jest. „Acta Universitatis Lodziensis. Folia Litteraria Polonica”, 2001, z. 2. S. 145-189.

Miszczak Magdalena. Manueli Gretkowskiej zabawy (z) kiczem. „Teksty Drugie” 1998, nr 6. S. 135-153.

Mizerka Anna. O publicznym wizerunku Manueli Gretkowskiej i estetyce kampu. „Podteksty” 2006, nr 1(3).

Nowacki Dariusz. Jeden Paryż i dwie techtaczki. „FA-art” 1994, nr 4. S. 60.

Floyd W. 2003. Critical History of the Aculturation Psychology of Assimilation, Separation, Integration, and Marginalization, „Review of General Psychology” 2003, nr 7(1). S. 3-37.

Sam David L. 2006. Acculturation: conceptual background and core components. W: The Cambridge Handbook of Acculturation Psychology. Red. John W. Berry, David L. Sam. Cambridge: Cambridge University Press. S. 11-27. 
Scheler Max. 1987. Pisma z antropologii filozoficznej $i$ teorii wiedzy. Przeł. Stanisław Czerniak i Adam Węgrzecki. Warszawa: Wydawnictwo Naukowe PWN.

Welsch Wolfgang. 2004. Tożsamość w epoce globalizacji - perspektywa transkulturowa. Przeł. z j. ang. Krystyna Wilkoszewska. W: Estetyka transkulturowa. Red. Krystyna Wilkoszewska, Kraków: Universitas. S. 31-43.

Wiedermann Adam. Tarot jest światem, a świat wariatem. „Czas Kultury”, 1993, nr 4. S. 93-95.

Wilkoszewska Krystyna, red. 2004. Estetyka transkulturowa. Kraków: Universitas.

Vierne Simone. 2000. Rite, roman, initiation, Grenoble: Presses Universitaires de Grenoble.

\title{
Marzena Karwowska
}

\section{IMAGES OF ACCULTURATION IN "THE PARISIAN TAROT"}

\author{
(summary)
}

The current state of research on acculturation indicates that this issue has gained a growing interest in recent years among researchers such as Rudmin, Berry, Kim, Abreu, Malewska-Peyre. In the 1930's, thanks to anthropologists such as Redfield, Linton and Herskovits, an understanding of the phenomenon of acculturation crystalized in the humanistic discourse. Already in the eighteenth century the idea of cultural identity in Western Europe interested Johann Gottfried Herder, who believed that every culture is homogeneous and national. A polemic with this vision of culture, which was paradigmatic for the nineteenth and twentieth century, was expounded by Wolfgang Welsch, who proposed his own concept of transculturality in the era of globalization. Wolfgang Welsch's concept of transcultural identity is an important turning point in the study of the phenomenon of acculturation, which, as a matter of interest to psychologists, anthropologists, sociologists and philosophers of culture, is usually analyzed at the group level and opens the way to transfer these studies to the level of creative individual experience, specified in literary texts.

The aim of the article is therefore an attempt to look at the image of acculturation fixed in the Parisian Tarot by Manuela Gretkowska, and the subject of interest are the artistic strategies for expressing this phenomenon.

\section{KEYWORS}

Manuela Gretkowska; Tarot paryski; acculturation 
Prace Polonistyczne, seria LXXII, 2017

ISSN: 0079-4791; e-ISSN: 2450-9353

DOI: $10.26485 / \mathrm{PP} / 2017 / 72 / 2$

Magdalena Lubelska-Renouf

\section{AKULTURACJA? CZY INNY WEKTOR WSPÓŁCZESNOŚCI? KILKA SŁÓW O REFLEKSJI CZESŁAWA MIŁOSZA}

\section{SŁOWA KLUCZOWE}

Miłosz Czesław; Cheng Françoi; Scheler Max; Cézanne; akulturacja; malarstwo chińskie; polska poezja; haiku

Załóżmy, że każda epoka ma własny Weltanschauung.

Załóżmy, że ten dzisiejszy wchłonął prawie wszystkie różnice kulturowe w strefie tak zwanego okcyndentalizmu i stał się kulturą dominującą niezależnie od historii i geografii. Że pozorny katolicyzm rdzennego Polaka prawie niczym nie różni się od pozornego islamizmu francuskiego Tunezyjczyka, a pozorny ateizm berkelejskiego intelektualisty od pozornego neopogaństwa internetowego nastolatka. Jednym słowem, że Max Scheler miał rację, mówiąc o „zacieraniu się przeciwieństw" (Scheler 1993: 67).

Załóżmy, że niektóre wybitne jednostki, bo już nie kultury, próbują popłynąć pod główny kulturalny prąd rzeki Weltanschauung. Czy jedyne, co je czeka to mielizna? Czyli, jak niedawno mówiono w nieco innym żargonie innego paradygmatu, śmietnik historii?

Inaczej mówiąc, załóżmy, że Max Scheler nie miał racji i że te potencjalne zbuntowane jednostki mają inny wybór niż ten między proponowanym albo: albo. Albo akulturacja (uzgodnienie własnych skłonności intelektualnych z kulturą dominująca) — albo mielizna, mierność i nicość.

Magdalena Lubelska-Renouf — dr, Professeur agrégé (PRAG), UFR de polonais, Sorbonne Paris 4, Centre universitaire Malesherbes, 108 bd Malesherbes, 75017 PARIS, FRANCE; e-mail: magdarenouf@gmail.com 
Załóżmy na koniec, że wiemy, czym jest dominujący współczesny Weltanschauung.

Ci, którzy weń wierzą, zgadzają się co do faktu, że każda epoka ma własne oryginalne doświadczenie, własny fundamentalny problem, który próbuje po swojemu rozwiązać i który ją definiuje i odróżnia.

Gorzej jest ze znalezieniem wspólnego mianownika.

Nie mając zamiaru przekształcić naszego artykułu w naukową, lub pseudo, inwentaryzację, powiedzmy sobie, że powszechnie stosowany dzisiaj termin najlepiej określa badane zjawisko. Będziemy więc z jednej strony, mówić o globalizacji; z drugiej strony, tej Czesława Miłosza, znajdziemy inną propozycję. Bo właśnie ten poeta będzie w naszym ujęciu jednostką, która próbowała płynąć pod prąd kultury, wybierając, czy stwarzając, inne wektory współczesności.

Miłosz nazwał naszą epokę neomanicheizmem i, po żmudnym odtworzeniu jego intencji, możemy dorzucić co najmniej dwa epitety do tego określenia: nihilistyczny i niemetafizyczny — oba ukryte w „neo” (Miłosz 1995: 21).

Zastąpmy metaforę naszej pierwszej roboczej hipotezy, płynięcia pod prąd, konkretnym stwierdzeniem: poezja Miłosza starała się umetafizycznić i odnicestwić nasz współczesny, dominujący, globalny nie-zawsze-świadomy, kulturalny-lub-nie, pan-neomanicheizm. Co nie oznacza, że powróciła do manicheizmu klasycznego - bo taki nigdy chyba nie istniał.

Jeżeli Miłoszowi udała się ta sztuka, a jest to nasza druga robocza hipoteza, to to poetyckie zwycięstwo byłoby naszą trzecią hipotezą, a mianowicie, że można wytyczyć inne wektory akulturacji, inne od tych, które znajdujemy u Maxa Schelera.

W pewnym sensie przynajmniej, ale $\mathrm{w}$ sensie natychmiast rozpoznawalnym jako sens ${ }^{1}$ — znaczenie i kierunek — Max Scheler miał rację. To, co on odgadywał jako nadchodzącą nowość, mówiąc o akulturacji i zacieraniu się przeciwieństw, jest naszą banalną codziennością. „Globalizacja” najbardziej rozpowszechniona dziś nazwa akulturacji, która dotarła wreszcie do kresu swoich możliwości, stając się jednym, wspólnym zbiorem czy zbiornikiem planetarnej kultury, jest na ustach wszystkich. To slogan, hasło, otwierające drzwi teraźniejszości i przyszłości:

Wszyscy [...] uważają „globalizację” za nieunikniony los świata, a także za nieodwracalny proces, kóry dotyczy każdego z nas w takim samym stopniu i w ten sam sposób (Bauman 2000: 5).

1 Sens: (XIe siècle): z łaciny (1) sensus (zmysł i znaczenie); (XIIe siècle) (2): z języków germańskich (kierunek, droga). 
Żadnej więc już dyskusji na temat spełnionej przepowiedni: jeżeli wszystkie nasze doświadczenia zyskują dzięki niej przejrzyste wyjaśnienie, jeżeli „Jesteśmy "globalizowani» a bycie "globalizowanym» znaczy to samo dla wszystkich, których ten proces dotyka" (Bauman 2000: 5), to w zasadzie możemy stwierdzić, że ten stan kultury stał się naszym nowym — naturalnym — środowiskiem i jedyne, co można w tej sytuacji zrobić, to dostosować się.

Akulturacja okazałaby się na koniec — naturalizacją. Ale właśnie w tym momencie ukazują się furtki zaznaczające możliwość wyjścia i pojawiają się głosy sprzeciwu tych, którzy próbują je otworzyć.

Jeden z nich należał do Czesława Miłosza.

Miłosz często porównywał swoją sytuację do kogoś, kto został zamknięty w ciemnym pokoju i ręką, na oślep, dotyka ścian, próbując odnaleźć ukryte drzwi (Miłosz 1997: 131).

Spróbujmy odtworzyć tok tych poszukiwań, zaczynając od ewidencji: poeta był $\mathrm{w}$ pełni świadomy analizowanego zjawiska, więcej, sytuacja globalizacji, rozpoznana jako intelektualnie jałowa i egzystencjalnie nie do zniesienia, była ważnym, może podstawowym, elementem jego dzieła, przesłanką i punktem wyjścia:

I oto ludzkość — jedna, zjednoczona kulturą filmu, telewizji, kaset, globalna wioska, w której na kontynentach i wyspach miliony białych, żółtych, brunatnych widzą to samo i zachowują się tak samo. [...] Jedna i niepodzielna cywilizacja nie jest nieszkodliwa. Jej inne imię jest bezosobowe, zbrutalizowane. Szlachetni filozofowie i teologowie ubolewający nad redukcją istoty ludzkiej do statusu zwierzęcia (żebyż to!) podobni są do ekologów bezsilnie przyglądających się, jak maszyny zwalają las dziewiczy w dorzeczu Amazonki. Gdyż dobre intencje niewiele mogą tam, gdzie ich przeciwnikiem nie jest żadna ideologia, żaden program, ale samorozmnażające się Nic. (Miłosz 1997: 22)

Miłosz jednak rzadko używa dominujących terminów, takich właśnie jak "globalizacja” czy „uniformizacja”, chociaż to on spolonizował amerykańskie pojęcia, leżące u podstaw tych zjawisk, wprowadzając do polszczyzny słowa, które zrobiły w niej zawrotną karierę - masowe środki przekazu i kultura masowa.

Fakt, że w swojej refleksji Miłosz unika pewnej terminologii jest faktem znaczącym: przemilczanie jednych i szukanie innych określeń świadczy już o próbie zmiany kierunku, próbie poszukiwania wyjścia z sytuacji, zdawałoby się, bez wyjścia. Miłosz używa więc innych nazw i najczęściej występujące, to przywołany już wcześniej „neomanicheizm” oraz „czarnowidztwo”. Czyli, w samym akcie nazywania fenomenu, podejmuje próbę jego waloryzacji (lub raczej dewaloryzacji) i zróżnicowania. Globalizacja, uniformizacja — te terminy są jak 
naturalne bloki granitu — jednolite, nieprzezroczyste i twarde; neomanicheizm natomiast jest już pewnym przekrojem, rzutem oka w głąb zjawiska — pozwala dojrzeć geologiczne warstwy, które je konstytuują, zrozumieć przyczyny i skutki.

Nadanie nowej nazwy, zrozumienie i przewartościowanie istniejących wektorów to pierwsze etapy zmiany sensu, sensu pojętego jako znaczenie i kierunek.

Zweryfikujmy tę terminologię: czarnowidztwo i neomanicheizm mają wspólny metaforyczny rdzeń: czerń. Manicheizm, w swojej esencji czarno-biały, $\mathrm{w}$ opisie materii przeciwstawionej niematerialnemu światłu (czyli transcendencji), jest całkowicie czarny: „świat w złu leży” (Jn 15, 18-19). Odczytując intencje Miłosza możemy więc uznać te terminy za mniej więcej jednoznaczne; odtąd będziemy mówić tylko o neomanicheizmie.

Czym jest dla nas manicheizm i dlaczego stał się, według Miłosza, wyznacznikiem naszej uniformizującej globalizacji?

Klasyczna definicja manicheizmu: „świat w złu leży” jest wciąż aktualna, ale nie potrzebujemy już dzisiaj dodatkowej wiedzy o tronach, potęgach, eonach, wpływach zoroastryzmu a nawet o trzonie manicheizmu, czyli o dualizmie. W neomanicheizmie dualizm, zasadnicze przeciwstawienie dobra i zła, światła i ciemności, ducha i materii, został nie tyle wyeliminowany, co przestawiony na inny tor. Powiedzmy, że z toru transcendencji został przestawiony na tor immanencji. Powiedzieliśmy wcześniej, że w przedrostku „neo” Miłosz zawarł dwie treści: nihilizm i negację metafizyki — możemy zradykalizować tę wizję i mówić po prostu o odrzuceniu transcendencji. Po której zostało Nic:

Prorok, jak sam to nazywał, nihilizmu europejskiego, Fryderyk Nietzsche, z dumą powiadał: „My nihiliści” i określał, co będzie „najskrajniejszą formą nihilizmu”. Będzie to „pogląd, zgodnie z którym wszelka wiara, wszelkie przekonanie, że coś jest zgodne z prawdą, będą z konieczności fałszywe dlatego po prostu, że nie ma prawdziwego świata. (Miłosz 1997: 42)

Dziwaczne koleje historii przekształciły arystokratyczny nihilizm Nietzschego najpierw w populistyczny nazizm, którego skutki, dobrze znane, doprowadziły $\mathrm{z}$ kolei do powstania równie populistycznej wersji neomanicheizmu:

Nie byłby chyba zadowolony, do czego w ciągu stu lat służyło jego dzieło. A bezgraniczna odwaga obrazoburcy, którą tak się szczycił? Cóż po niej dzisiaj, kiedy trzeba odwagi, żeby twierdzić coś przeciwnego? (Miłosz 1997: 43)

Mamy tutaj, według Miłosza, jedno z najbardziej obłędnych kół zatoczonych przez naszą kulturę i historię: transcendencja (i jej pochodne: prawda, Bóg, natura człowieka) zostaje odrzucona w imię nihilizmu, który przynosi wolność, to odrzucenie doprowadza do ludobójstwa, ludobójstwo prowokuje traumę, która 
z kolei prowadzi do oskarżenia transcendencji a następnie z powrotem do nihilizmu pojętego jako zabezpieczenie i przed transcendencją, i przed wolnością².

Definicja neomanicheizmu brzmiałaby więc mniej więcej tak: „system niereligijny, dominujący w świecie począwszy od XX wieku. Był reakcją na wydarzenia historyczne, które zostały odczytane jako katastrofa, po której nastąpiła śmierć Boga. Może zostać ujęty w stwierdzeniu: «świat w złu leży i nie ma prawdziwego świata»".

W naszej pół-żartobliwej parafrazie Wikipedii, która jednak dość wiernie odtwarza koncepcję Miłosza, odnajdujemy pewien specyficzny rys myślenia o kulturze: kiedy stwierdzamy, że „neomanicheizm był reakcją na”, to definiujemy fenomen kultury jako fenomen organiczny. I wtedy, kiedy w mówieniu o kulturze stosujemy metaforę choroby, możemy ją wzbogadzić o nowy element: leczenia.

Wystarczy dość pobieżny rzut oka na współczesne opisy kultury, żeby zauważyć pewną stałą: jest nią właśnie specyficzna metaforyka choroby. Zdanie „chorobą naszych czasów jest...” (Sosnowski 2015: 244)33 pojawia się regularnie w esejach nauk humanistycznych. Tradycja ta ma długi rodowód: kiedy obserwujemy, jak niektóre znaki (wartości, dzieła, symbole, obyczaje) zostają przez daną kulturę przyswojone, inne zaś z niej wyeliminowane, trudno nie skojarzyć tego zjawiska z systemem immunologicznym działającym wewnątrz organizmu.

Jest to szczególnie widoczne w terminie ukutym przez Miłosza, gdzie przedrostek „neo” wyznacza elementy odrzucone i sugeruje alergię, a człon — „manicheizm" - zawiera substancje pożądane i przepuszczane przez organizm. Alergia, ten skuteczny mechanizm obronny byłaby w naszej metaforze, wynikiem urazu — reakcją na kataklizmy XX wieku.

Pamiętamy, że zawarte $\mathrm{w}$ „neo” elementy: nihilizm (nihil = nic) i negacja metafizyki (czyli tego, co „jest” poza fizyka), sprowadziliśmy do wspólnego mianownika - odrzucenia transcendencji. Lub mówiąc prościej — religii:

Cywilizacja, w której tkwię, zaprzecza religii [...]. Każdy mój dzień z jego mnóstwem postrzeżeń ćwiczy mnie w antyreligii i nie mogę przypisać żadnym zrozumiałym dla mnie intencjom olbrzymich neonowych napisów głoszących: „Jezus ratuje od grzechu". (Miłosz 1995: 73)

Według diagnozy, którą postawiono kulturze w dwudziestym wieku, transcendencja byłaby tą substancją, która doprowadziła kulturalny organizm do katastrofy i przed którą broni się on dzisiaj za pomocą alergii. Główne, alergo-

2 Ten sam typ błędnego koła opisany został, profetycznie, przez Dostojewskiego w Braciach Karamazow jako „sziglajewszyzna”.

3 Przytaczam tu uwagi Jerzego Sosnowskiego na ten temat, bo w porządku chronologicznym są one najnowsze. 
genne, „składniki” transcendencji w wersji Miłosza to przede wszystkim pojęcie prawdy, typu metafizycznego, czyli prawdy o człowieku, Bogu i świecie, wspólnie konstytuujące tak zwaną rzeczywistość. Jej charakterystyką jest ruch w osi pionowej — podział na górę i dół; jej elementy pochodne to autorytet i hierarchia.

Te właśnie substancje, rozpoznane „wczoraj” jako ludobójcze, a „dzisiaj” jako alergogenne, zostały starannie wyeliminowane z naszej globalnej, chudej diety:

Są tacy, którzy wolą Nic niż religię z jej politycznym złem. Bo doświadczenie wykazuje, że człowiek owija się w podniosłość, czystość i szlachetność wysokiej sfery ducha, żeby udawać, że nie wie, co robią jego ręce. Tylko gdyby katolicyzm był wolny od takiej podwójności, miałby prawo wytknąć prawosławiu zbrodnie Karadżicza. (Miłosz 1997: 41)

Zauważmy, że eliminacja („wybór Nic”) jest tylko jednym ze sposobów neutralizacji szkodliwych dla organizmu substancji. Miłosz wspomina o innej możliwości, o neutralizacji przez deformację: Religia może zostać zdeformowana i wyeliminowana przez „rozmiękczenie” i wtedy rezultatem jest tak zwana „papka New Age", w której miesza się buddyzm w plastikowym opakowaniu, chrześcijaństwo i inne elementy pseudo religijne (Miłosz 1995: 251); albo, na odwrót przez „stwardnienie” — czyli wszelkiego rodzaju religijne integryzmy.

A jednak, Miłosz, dobrze wiedząc, że cieniem religii (Prawdy, Boga i świata) jest polityczne zło, w całym swoim dziele przeprowadza kontestację tego rozpoznania, udowadniając szkodliwość nihilizmu, który zlikwidował transcendencję. Szkodliwość ta według Miłosza może być subiektywna:

Rechoczącym cynikom, wbijającym ludziom w głowy, że nie ma dobra ni zła, że życie jest kłębowiskiem gryzących się szczurów, nie można powiedzieć: „skazujecie siebie na męki wieczne", bo śmieją się z wiary w życie po śmierci. Można jednak powiedzieć: „skazujecie siebie na wygraną, i to będzie dla was dostateczną karą”. (Miłosz 1997: 43)

Szkodliwość ta może prowadzić również do obiektywnego zagrożenia:

Czy Nic, święta dziura w umysłach zachodniej Europy, nie będzie pokusą dla islamskiego fundamentalizmu, który w imię Boga występuje już nie przeciwko niewiernym, ale ludziom pozbawionym jakiejkolwiek wiary? (Miłosz 1997: 44)

Miłosz otwarcie (i do końca) broni odrzuconych pojęć: prawdy, metafizyki (teologii) oraz absolutnego punktu odniesienia (Boga):

Dlaczego teologia? Bo pierwsze ma być pierwsze.

A tym jest pojęcie prawdy. I właśnie poezja swoim zachowaniem przerażonego ptaka tłukącego się o przezroczystą szybę, poświadcza, 
że nie umiemy żyć w fantasmagorii.

Oby do naszej mowy wróciła rzeczywistość.

To znaczy sens, niemożliwy bez absolutnego punktu odniesienia.

(Miłosz 2002: 63)

Być może podłożem tych poszukiwań innej rzeczywistości i innego rozpoznania choroby kultury, bardziej niż zagrożenie subiektywnym cynizmem i obiektywnym terroryzmem, jest jego własna alergia na nihilizm, do której często się przyznaje:

W starości, znalazłszy się w tropikalnym kraju, już wiedziałem, że zawsze szukałem lekarstwa na tę ohydę, która tym trwa, że nic nie znaczy. Nadać sens, jakikolwiek, byle nie ta krowia, doskonale obojętna rzeczywistość, bez celów, dążeń, afirmacji, negacji, niby ucieleśniona nicość. Religie! Ideologie! Pragnienia! Nienawiści! Przybywajcie, żeby zakryć waszą wzorzystą tkaniną to ślepe, które nawet nie ma nazwy. (Miłosz 1997: 67)

Nie wnikając w intencje, zadowólmy się opisem strategii.

Podkreślmy raz jeszcze: Miłosz, bardzo dobrze wiedząc, że cieniem transcendencji (prawdy, Boga i świata) jest polityczne zło, nie zgadza się z wnioskami nihilizmu i próbuje, w całym swoim dziele, postawić inną diagnozę. Wytyczyć nowe wektory sensu.

Sprawa jest skomplikowana, gdyż tych wektorów czy linii ścieżek, które prowadzą poza obszar neomanicheizmu, jest w dziele Miłosza wiele. W ramach tego artykułu możemy wykroić jedynie bardzo wąski skrawek refleksji, starając się wybrać fragment, który wydaje się nam najbogatszy, z nadzieją, że krzyżują się w nim wszystkie pozostałe linie.

Substancją szkodliwą czy wręcz zabójczą w diagnozie Miłosza jest kartezjański dualizm i Miłosz podejmuje systematyczną krytykę tego nurtu, który napotkał w naszej zachodniej kulturze warunki wybitnie sprzyjające, rozwijając się w patologiczny sposób i doprowadzając do zwyrodnienia transcendencji ${ }^{4}$. To on byłby główną, chociaż nie jedyną, przyczyną podwójnej katastrofy.

Pierwsza katastrofa została już opisana jako totalitarna i ludobójcza próba narzucenia całemu światu religijnych (czy pochodnych od religii) koncepcji prawdy, człowieka, świata i Boga. W jej opisie poeta zasadniczo zgadza się ze

4 Nietzsche odrzucałby więc tę właśnie zwyrodniałą formę transcendencji, co w pewnym sensie, w oczach Miłosza, jest usprawiedliwione. 
zwolennikami neomanicheizmu, lecz przyczyn tego stanu rzeczy szuka głębiej niż oni. Dla neomanichejczyków główna przyczyna katastrofy to jak najszerzej pojęta transcendencja. Według Miłosza jest to ujęcie zbyt płytkie, nie sięgające dostatecznie w głąb geologicznych warstw naszej historii. Bowiem religijne koncepcje prawdy, człowieka, świata i Boga uległy dość wcześnie poważnym schorzeniom, z których najpoważniejszym jest właśnie koncepcja kartezjańskiego dualizmu, czyli, ujmując to jak najszerzej, podział na ciało i ducha, materię i duchowość i, przede wszystkim, na podmiot i przedmiot. Drugą zaś katastrofą byłaby w wizji Miłosza sama błędna diagnoza i jej pochodna tzn. neomanicheizm. A także niewłaściwe lekarstwa aplikowane pacjentowi rzekomo choremu na transcendencję — subiektywizacja (Freud, Lacan i większość współczesnej literatury, która podważa rzeczywistość świata, przesuwając akcent na subiektywną percepcję, twierdząc, „że niby oprócz tych percepcji nic nie ma” — Miłosz 1995: 246), a także wymienione już: nihilizm, cynizm, negacja transcendencji, synkretyczna papka New Age - lekarstwa, które mogą doprowadzić do zejścia samego pacjenta.

Jedną z ciekawszych propozycji „medycznych” Miłosza, który chciałby wyleczyć transcendencję z kartezjańskiego dualizmu (podziału na podmiot i przedmiot) jest rodzaj poetyckiego ekumenizmu. Po uważnym przeglądzie wątków, których ślady możemy odnaleźć prawie w każdym eseju i w wielu wierszach

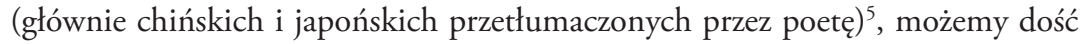
łatwo streścić tok jego rozumowania.

Zacznijmy od podstawowego przekonania poety, według którego powrót do poprzednich faz kultury jest niemożliwy; kiedy mówi o przyśpieszeniu historii, odkryciach naukowych, o globalizacji, zawsze pojawia się myśl o tej niemożliwości i zdanie „Nie oczekiwać, że wyobraźnia, kiedy raz zaczęła krążyć po swoich nowych orbitach, zdolna będzie się zatrzymać. $Z$ tego, co jest słabością, zrobić napęd siły — oto sposób” (Miłosz 1995: 25) można uznać za streszczenie wybranej strategii.

Skoro więc jesteśmy w fazie globalizacji — w planetarnej wiosce - z tego faktu należy zrobić napęd siły; wytworzyć inne układy globalizacji, inne niż uniformizacja w postaci miękkiej (papka New Age, subiektywizacja) czy twardej (neomanicheizm):

Co robił Staff, co robili inni tłumacze poezji chińskiej i japońskiej w dwudziestym wieku? Nic innego, jak dokonywali nieuniknionego połączenia Wschodu i Zachodu, nieuniknionego, bo dom nasz, planeta Ziemia, już przestaje być, na złe czy na dobre, podzielony na odgrodzone pola i zamknięte pokoje. Innym aspektem tego ruchu jest obecność religii wschodnich w Ameryce i w krajach Europy oraz ekumeniczne poszukiwania teologów chrześcijańskich [...] (Miłosz 1997: 383)

5 Patrz Przektady poetyckie: Poeci chińscy, s. 191-219 i Zen codzienny, s. 375-439. 
Należy odnaleźć czy raczej wypracować taki układ akulturacji, w którym oddzielne systemy (tutaj bardzo szerokie: Wschód/Zachód) nie będą się wzajemnie osłabiać, lecz wzmacniać. Miłosz wybiera ten fragment styku, na którym główna słabość Zachodu, czyli, według niego, kartezjański dualizm, może zostać wzmocniony czy uzupełniony przez myśl - poezję, religię (tutaj rozróżnienie prawie zanika) - Wschodu. Miłoszowi nie chodzi, co bardzo mocno podkreśla, o buddyzację chrześcijaństwa, ale o wzmocnienie najsłabszej jego strony, którą odkrywa w subiektywizacji i która doprowadza do osłabienia rzeczywistości. Ruch na osi Zachód/Wschód w refleksji Miłosza nie jest jednokierunkowy, ale dwukierunkowy, to rodzaj podróży — tam i z powrotem:

Przykład poezji Dalekiego Wschodu zachęcił mnie do szukania podobnych zalet, jakie w niej znalazłem i gdzie indziej. Tak jak po zwiedzeniu sal malarstwa odległych krajów wracamy do sal malarstwa rodzimego i widzimy je inaczej, tak poezja Europy i Ameryki ukazała mi pewien szczególny nurt, na który nie zwracałem dotychczas szczególnej uwagi. Zacząłem wybierać wiersze w różnych językach, które podobały mi się przez to, że honorują przedmiot, nie podmiot. (Miłosz 1997: 100)

Tę swoją kulturalną podróż tam i z powrotem, Miłosz streszcza mocno, melancholijnie i zabawnie jednym zdaniem: „Całe życie badał, podpatrywał sekrety wielkich mistrzów malarstwa, po to tylko, żeby namalować strumień koło swojej rodzinnej wioski i dwie gęsi na brzegu”. (Miłosz 1997: 8)

A oto właściwy tok rozumowania o dualizmie, który Miłosz podaje nam w jednym ciągu; jako streszczenie:

Powoływałem się kilka razy na buddyjskiego filozofa ze szkoły Kyoto, Keiji Nishitaniego, który napisał wielkie dzieło Religia i Nicość. Otóż wysuwa on tezę, że filozofia zachodnia zajmowała się stosunkiem podmiotu do przedmiotu w ten sposób, że celem podmiotu było poznać przedmiot, czyli rzeczywistość i opanować ją, podporządkować sobie. [...]. Według Nishitaniego, ten długi proces, ta ewolucja doprowadziła filozofię do samozaprzeczenia, do nihilizmu, gdyż „Ja”, podmiot w swoim zmaganiu, w swojej konfrontacji z przedmiotem doszedł najpierw do zanegowania przedmiotu, na którego miejscu stanęło tylko „Ja” (czyli do skrajnego subiektywizmu); z kolei owo "Ja" i jego rzeczywistość same zostały zanegowane. Najpierw więc nastąpiła utrata podstawy wszelkiej rzeczywistości czyli Boga — więc nastąpiło to, co nazwano „śmiercią Boga” (u Nietzschego), a potem doszło do „śmierci człowieka”. U Nishitaniego, lekarstwem na nihilizm jest — paradoksalnie — buddyzm, ponieważ w buddyzmie nie ma przeciwstawienia podmiot-przedmiot, podstawą, tłem, zarówno dla jednego jak i drugiego jest Pustka, Nicość — Sunjata ${ }^{6}$. Paradoksalnie, w ten sposób podmiot

${ }^{6}$ Pustka czy nicość w buddyzmie, jak Miłosz podkreśla, nie może być rozumiana w sensie nihilistycznym czy ontologicznym — jest to także Pełnia, rodzaj zbiornika energii, która zasila czy wypełnia jednocześnie podmiot i przedmiot (MP, 237). 
i przedmiot umieszczone są w innym stosunku — raczej utożsamienia niż zderzenia. (Miłosz 1995: 237)

Te rzeczy są dzisiaj znane i nie chodzi nam o ich przypominanie. Znany jest również wkład Miłosza w ich popularyzację: tłumaczenia haiku, skomponowanie książki Wypisy z ksiag użytecznych, w której jak stwierdza sam autor, udało mu się wyrazić swoje "instynktowne przywiązanie do świata widzialnego, dotykalnego, sensualnego” (Miłosz 1995: 247), jego własne wiersze „buddyjskie”, w tym najważniejsze: O zbawieniu (Miłosz 2011: 1353) i To jedno (Miłosz 2011: 914) gdzie odnajdujemy tę samą obronę rzeczywistości przed wszystkożernym podmiotem Kartezjusza. Kluczem do interpretacji pierwszego poematu byłaby pierwsza połowa buddyjskiego koanu: „jest poznanie, ale nie ma poznającego”, kluczem do drugiego - druga połowa: ,jest widzenie, ale nie ma widzącego”.

Znane jest również przekonanie Miłosza, że „katolicyzm może dużo zyskać na spotkaniu z buddyzmem" (Miłosz 1995: 241) i jego próby zakreślenia pewnego wspólnego zbioru dla dwóch religii, które, sprzymierzone, mogłyby wytoczyć na wspólnym terenie bitwę o transcendencję i rzeczywistość przeciwko subiektywnej nihilizacji:

Buddyzm wprowadza wymiar kosmiczny i tu spotyka się z katolicyzmem. Wymiar kosmiczny, bo mamy w buddyzmie ten ogromny wymiar czasu i to ustawiczne rodzenie się i umieranie - to jest jakiś wielki, olbrzymi wymiar. Tak samo jest w katolicyzmie: świętych obcowanie i śmierć Chrystusa pojęta nie tylko jako wydarzenie historyczne ale i kosmiczne; to również ten wymiar, nad którym ludzie niedostatecznie myślą. (Miłosz 1995: 251)

Te przekonania Miłosz dzieli z wieloma innymi badaczami współczesności: Tomaszem Mertonem i Józefem Tischnerem, żeby ograniczyć się do nazwisk najbardziej mu bliskich ${ }^{7}$.

Ciekawszą, bo może mniej znaną, sprawą byłaby próba rozwinięcia jego intuicji, które zaczęły się materializować znacznie później, a na które Miłosz, zgodnie z naszą metaforą wektorów rozwoju, jedynie wskazał palcem.

Kiedy Merton, Tischner, Nishitani, mówią o pożytku myśli buddyjskiej dla oczyszczenia i wzbogacenia chrześcijaństwa, myślą głównie w sposób jednokierunkowy: buddyzm jest tutaj ważny dla chrześcijaństwa. Jednak Miłosz sugeruje również coś w rodzaju sprzężenia zwrotnego — ruch dwukierunkowy. Istnieją dzisiaj teksty teologiczne i antropologiczne, które tę intuicję rozwijają ${ }^{8}$ Nie chodzi nam o wykazywanie zależności — wystarczy powiedzieć, że Miłosz,

\footnotetext{
Patrz Józef Tischner, Ksiądz na manowcach i Tomasz Merton, The Asian Journal.

8 Na przykład teksty R. Panikkar'a, T. Halika i inne.
} 
szukając ukrytych w ciemnym pokoju drzwi, natrafił ręką na przynajmniej jedno wyjście z globalnej i nihilizującej uniformizacji.

Rozwinięcie tego tematu przekracza tutaj nasze możliwości. Nie jest to oczywiście temat nieznany, przeciwnie, wielu badaczy pisało o intuicjach Miłosza i jego fascynacji buddyzmem 9 . Nie chodzi nam jednak tutaj o jego pogłębienie, chcielibyśmy raczej wskazać na zupełnie nowe ujęcia tego fenomenu w twórczości, która nie zajmuje się pisarstwem Czesława Miłosza. Wymienimy więc tylko dwa nazwiska współczesnych autorów całkowicie dwu-wyznaniowych, dla których buddyzm i chrześcijaństwo są jednakowo ważne i którzy wytyczają linie przecięć, pozwalające na obopólne wzbogacenie.

Ramon Panikkar, teolog uznany za jednego z ważniejszych we współczesnym świecie, w swoim teologicznym dziele L'expérience de Dieu rozwija temat przezwyciężenia zachodniego dualizmu, zajmując sie głównie tematyką katolickiej Trójcy - pogłębionej przez buddyjskie pojęcia advaity. Zajmuje się również kwestią przezwyciężenia pewnych tendencji w buddyzmie, które radykalizują pojęcie nicości, szukając pomocy w katolickiej koncepcji hipostaz: kto szuka?

Nie-dualistyczna wizja (advaita), w której boskość nie jest indywidualnie oddzielona od reszty rzeczywistości ani nie jest z nią całkowicie tożsama byłaby tutaj pomocna. Upaniszady np. zajmują stanowisko religijne, które nie opiera się ani na dialogu ani na monologu, ale na ponad-racjonalnym doświadczeniu „rzeczywistości”, która nas w pewien sposób „wchłania” w samą siebie. Jest to ta część mądrości, którą Azja może zaoferować zachodniej kulturze, tzn, upraszczając, nie-dualistyczna wizja rzeczywistości. I ta wizja może dopełnić obraz Trójcy. Z kolei relacyjność hipostaz wewnątrz Trójcy może uzupełnić obraz buddyzmu. Bóg nie jest ani Jednym (monizm), ani Innym (dualizm). Bóg jest biegunem rzeczywistości, jej biegunem twórczym; jest milczący, a więc niewyrażalny a jednak mówi w nas; jest transcendentny, ale immanentny w świecie; nieskończony a jednak ograniczony w rzeczach. Biegun jest niczym sam w sobie. Istnieje jedynie jako biegunowość — w relacji. Bóg jest relacją, intymną i wewnętrzną relacją ze wszytkim. (Panikkar 2014: 93)

Autor rozwija tutaj swoją koncepcję kosmotheoantropocentryzmu, która zdaje się dopełniać kosmiczne intuicje Miłosza.

Inny współczesny poeta, malarz i eseista, francuski akademik pochodzenia chińskiego — François Cheng, od lat opisuje swoją koncepcję piękna, w której splatają się chrześcijańskie i buddyjskie wątki — bardzo bliskie wizjom Miłosza.

9 Z najnowszych badań należy wymienić tu tekst Jerzego Jarzębskiego „N'être qu’un pur regard sans nom": Czestaw Mitosz et la souffrance du moi (w: Chauvin Danièle, red. 2013: 16 stron), Michała Masłowskiego Mitosz, Merton et le bouddhisme zen (w: Chauvin Danièle, red. 2013: 20 stron), książkę Agaty Stankowskiej Żeby nie widzieć oczu zapatrzonych w nic. O twórczości Czestawa Mitosza (Poznań 2013). 
Szczególnie rozważania Chenga o malarstwie - chińskim i europejskim wzbudzają u czytelnika Miłosza wrażenie déjà vu. Odnajdujemy tu ten sam ruch dwukierunkowy, podróż tam i z powrotem na terenie malartswa i poezji. Więcej — odnajdujemy tego samego malarza, który służy za łącznik dwóch tradycji - za ogniwo dorzucone w najsłabszym punkcie zachodniego łańcucha malarstwa (Cheng 2011: 47).

Miłosz często pisał o niebezpieczeństwie subiektywizacji także w malarstwie zachodnim, o impresjonizmie, który jest według niego „otwarciem jakiejś tamy subiektywizmu [...], coraz bardziej natrętnego opowiadania malarza o sobie; [...] malarstwo tylko jako to, co ja odczuwam, co ja tworzę, widzę...” (Miłosz 1995: 248). I odczytywał kubizm jako próbę oporu:

Niemniej zagadnienie cech stałych, niejako ukrytych w przedmiocie, było dla wielu niepokojące, na przykład dla kubistów, którzy analizując gitarę, jabłko czy ludzką twarz odkrywali, że składają się one z figur geometrycznych. (Miłosz 1997: 109)

Cézanne pojawia się w tym samym miejscu wywodu u Miłosza i u Chenga.

Cheng, podobnie jak Miłosz, zauważa, że klasyczne malarstwo zachodniej kultury odzwierciedla tę samą dualistyczną filozofię, która znalazła najpełniejszy wyraz w kartezjanizmie: stawia podmiot w pozycji uprzewilejowanej — ponad lub przed przedmiotem. Postać lub twarz znajdują się przeważnie na pierwszym planie — reszta służy za tło.

Miłosz napisał sporo wierszy malarskich i na temat malarstwa - prawie wszystkie wybrane obrazy mają jedną wspólną cechę — postać ludzka wychodzi z pierwszego planu i wtapia się — zmniejszona w tło albo znika zupełnie. Opisywał więc sceny z Corota, Turnera, malarstwa holenderskiego. Malarz, który wciąż powraca w jego poezji — ale w esejach jest wymieniony z nazwiska — to właśnie Cézanne, niekoniecznie jako kubista. Cézanne fascynuje Miłosza, ponieważ góra czy sosna, wciąż od nowa malowana w setkach odmian, wchłonęła - w sensie prawie dosłownym - malarza, który ją malował. Świat węwnętrzny Cézanne’a to góra Sainte-Victoire; a sam Cézanne zniknął, „wessany z siłą absolutną”, zostawiając po sobie hieroglificzny znak — podpis pośpiesznie rzucony w rogu obrazu (Miłosz 2011: 378).

Cézanne fascynuje również Cheng’a, ktory stawia podobne pytania, i, zastanawiając się nad zniknięciem Cézanne’a, pyta: a może jest na odwrót? Może to Cézanne wchłonął w siebie górę i to, co z niej zostało to obraz Cézanne’a - hieroglificzny znak jego życia wewnętrznego? Lub może obie wersje są prawdziwe? (Cheng 2011: 97). 
Refleksje Chenga są równie fascynujące, co mało znane, a ponieważ wydają się nam przedłużeniem refleksji Miłosza — przedłużonym wektorem wskazującym na wyjście z neomanicheizmu, pozwolę je sobie tutaj odtworzyć ${ }^{10}$.

Cézanne wciąż powracał do góry Sainte-Victoire, opowiada Cheng, stając przed nią w postawie przyjmującej i ofiarowującej zarazem. Wiedział, że musi otworzyć w sobie pustą przestrzeń, aby góra mogła w nią wejść, aby ta ogromna rzecz, przekraczająca go nieskończenie, mogła w nim zamieszkać. Czyli to, co nazywamy światem wewnętrznym, musiało najpierw stać się całkowicie puste, opróżnione z każdej rzeczy, którą nazywamy swoją, żeby przyjąć w siebie coś, co wchodzi weń z zewnątrz. W przestrzeń wewnętrzną malarza wchodziła potężna geologiczna siła, która od momentu wytrysku pierwszego ognia, wciąż, warstwa po warstwie, wspinała się nieprzerwanie wzwyż, w nieograniczoną przestrzeń powietrza, na spotkanie światła, odbijanego przez milion skrystalizowanych powierzchni granitowego bloku. $\mathrm{Z}$ powodu tej gry lustrzanych odbić, innych w każdej porze dnia i roku, tej bezustannej metamorfozy góry, Cézanne nie mógł się od niej oderwać i proces przyjmowania/ofiarowywania powtarzał się wciąż od nowa. Cézanne, oślepiony górą, zamienił się w oranta. Dobrze wiedząc jaka jest cena wpatrywania się w światło.

Malarz spalił się w oślepiającej kontemplacji.

Cézanne, ciężko chory, pustoszony przez nieustające migreny, wychodzi jak co dzień na spotkanie z górą Sainte Victoire. Wybucha burza. Cézanne traci przytomność i leży kilka godzin w gwałtownej ulewie. Umiera tego samego dnia. (Cheng 2011: 99)

Co po sobie zostawił? Swój świat wewnętrzny w postaci kilkunastu kwadratów płótna, na którym namalował hieroglif góry? Czy sam ten zewnętrzny pejzaż, który go zafascynowat: ogromny blok granitu?

I co chciał zrobić? - Mógłby spytać w tym momencie Miłosz — pochłonąć górę? Czy zniknąć? - tak, aby góra mogła stanąć na jego miejscu? Ruch jego pędzla był dośrodkowy? Czy odśrodkowy? Próbując odpowiedzieć na to pytanie, Miłosz czyta Nishitaniego, analizuje i tłumaczy poezję chińską i japońską. Pisze buddyjskie wiersze. Szuka wyjścia prowadzącego poza dualizm. I z Chin i Japonii wraca z powrotem do Europy, widząc już co innego w zachodniej kulturze.

Cheng, poeta i malarz, w swoim mieszkaniu tuż koło Louvre zwraca się do własnej, ojczystej kultury — do tradycyjnego malarstwa Chin.

Opowiada swoją pierwszą, sprzed ponad pół wieku, lekcję malarstwa u starego mistrza - przedstawiciela tradycji Song i Yuan (Cheng 1979: 65). Jaka jest

${ }^{10} \mathrm{~W}$ poniższym wywodzie dokonuję kompilacji kilku dzieł François Chenga, które wymieniam w bibliografii. 
autentyczna rzeczywistość człowieka na łonie żywego wszechświata, uchwycona w malarstwie Song i Yuan? Ich wizja, wyjaśnia stary mistrz, jest możliwa tylko wtedy, kiedy dusza człowieka wchodzi w rezonans z duszą uniwersalną, i dopiero ten stan rezonansu (shen-yun) jest najwyższym poziomem sztuki. Dusza uniwersalna nie jest naturą, ona jest poza naturą: to Tao — Droga, w której trwa Pustka pierwszego początku i pierwszy Oddech. Sama natura nie mówi nam niczego w sposób bezpośredni, gdyż to własnie my jesteśmy jej otwartym okiem i bijącym sercem.

$\mathrm{Na}$ chińskich obrazach często widzimy to samo: ogromny pejzaż góry, spadająca kaskada wody, naśladująca ją kaskada sosny, całość jakby wstrząsana nieustannym dreszczem, poruszana niewidocznym rytmem oddechu. W sercu pejzażu - mała postać człowieka - prawie całkowicie zagubionego w ogromie przestrzeni, zanurzonego we mgle Wielkiej Całości - człowieka, który widzi. Jeśli cierpliwie będziemy wpatrywać się w ten obraz, my również ujrzymy lub poczujemy, że postać ludzka znajduje się naprawdę w uprzywilejowanym miejscu widzenia, i że możemy się z nią utożsamić — razem z nią cieszyć się widokiem. Zobaczymy, że właśnie ta postać jest okiem i sercem olbrzymiego ciała. Jest jakby osią, wokół której rozpościera się organiczna przestrzeń, która powoli staje się przestrzenią wewnętrzną — człowieka, który widzi. Człowiek nie jest już osobnym, wykorzenionym bytem, który patrzy na wszechświat z zewnątrz. Jeżeli potrafimy widzieć świat — świat widzi nas. Nasza rzeczywistość, byt, życie, przeznaczenie - jakkolwiek to nazwiemy — jest częścią większej, kosmicznej rzeczywistości. I fakt ten nie tyle nas pomniejsza, co nas powiększa : nasza rzeczywistość zostaje postawiona w perspektywie otwarcia.

I Cheng wymawia słowo przezwyciężające dualizm: advaita.

W swoich rozważaniach na temat niewystarczalności dualistycznej postawy kartezjanizmu, w swoich wierszach, Miłosz szuka tej właśnie otwartej perspektywy, dzięki której wiersz staje się „czystym widzeniem bez nazwy”... Szuka momentu, w którym „ja” podmiotu zanika, wewnętrzna przestrzeń wchodzi $\mathrm{w}$ przestrzeń z zewnątrz i wiersz zamienia się w oko świata.

\section{To jedno}

Dolina i nad nią lasy w barwach jesieni.

Wędrowiec przybywa, mapa go tutaj wiodła,

A może pamięć. Raz, dawno, w słońcu,

Kiedy spadł pierwszy śnieg, jadąc tędy

Doznał radości, mocnej, bez przyczyny,

Radości oczu. Wszystko było rytmem

Przesuwających się drzew, ptaka w locie, 
Pociągu na wiadukcie, świętem ruchu.

Wraca po latach, niczego nie żąda.

Chce jednej tylko, drogocennej rzeczy:

Być samym czystym patrzeniem bez nazwy,

Bez oczekiwań, lęków i nadziei,

Na granicy, gdzie kończy się ja i nie-ja.

\section{BIBLIOGRAFIA}

Bauman Zygmunt. 2000. Globalizacja. Przeł. Ewa Klekot. Warszawa: Państwowy Instytut Wydawniczy.

Chauvin Danièle, red. 2013. Czestaw Mitosz, dialogue des cultures. Paris: Presses Universitaires Paris-Sorbonne.

Cheng François. 1979. Vide et Plein. Le langage pictural chinois. Éditions du Seuil.

Cheng François. 2006. Cinq méditations sur la beauté. Paris: Albin Michel.

Cheng François. 2011. Eil ouvert et cour battant. Paris: Desclée de Brouver.

Cheng François. 2013. Cinq méditations sur la mort. Paris: Albin Michel.

Cheng François. 2016. De l'âme. Paris: Albin Michel.

Merton Thomas. 1973. The Asian Journal of Thomas Merton. New York: New Directions Publishing.

Miłosz Czesław. 1995. Metafizyczna pauza. Kraków: Znak.

Miłosz Czesław. 1997. Piesek przydrożny. Kraków: Znak.

Miłosz Czesław. 1997. Żcie na wyspach. Kraków: Znak.

Miłosz Czesław. 2002. Druga przestrzeń. Kraków: Znak.

Miłosz Czesław. 2005. Przekłady poetyckie. Kraków: Znak.

Miłosz Czesław. 2011. Wiersze wszystkie. Kraków: Znak.

Panikkar Raimon. 2014. L'expérience de Dieu. Paris: Albin Michel.

Stankowska Agata. 2013. „Żeby nie widzieć oczu zapatrzonych w nic”. O twórczości Czestawa Mitosza. Poznań: Wydawnictwo Naukowe Uniwersytetu im. Adama Mickiewicza.

Scheler Max. 1993. Problèmes de sociologie de la connaissance. Paris: PUF.

Sosnowski Jerzy. 2015. Co Bóg zrobit szympansom? Warszawa: Wielka Litera.

Tischner Józef. 1999. Ksiądz na manowcach. Kraków: Znak. 
Magdalena Lubelska-Renouf

\title{
ACCULTURATION? OR ANOTHER VECTOR OF MODERNITY? REFLECTIONS ON THE THOUGHTS OF CZESŁAW MIŁOSZ
}

\author{
(summary)
}

While Max Scheler's acculturation problematic is once more topical, under the better known term "globalisation" (in the sense of westernisation), there are vectors in our culture that appear to run counter to this unifying trend. In our article, we examine one of Czesław Miłosz's poetic intuitions that is today "embodied" in the writings of François Cheng, the Chinese-born French poet and thinker. In his essays on beauty, we analyse the swinging back and forth between poetry, thought and painting; we also examine the meeting of Eastern (Buddhist and Taoist) and Western (Christian) thought; a meeting that Cheng and Miłosz particularly perceived in the pantings of Cézanne and which, while constituting a link between these two traditions, would, according to them, also make up for the greatest western weakness, i.e. Cartesianism.

\section{KEYWORDS}

Miłosz Czesław; Cheng François; Scheler Max; Cézanne; Acculturation; Chinese painting; Polish poetry; haïku 


\section{BYĆ OBCYM U SIEBIE? MARCIN ŚWIETLICKI I BARBARA GRUSZKA-ZYCH WOBEC ZNAKÓW PRZYNALEŻNOŚCI}

\section{SŁOWA KLUCZOWE}

Marcin Świetlicki; Barbara Gruszka-Zych; polska poezja współczesna; poezja francuska; znak; symbol; przynależność; obcość; kultura; akulturacja

Akceptacja tego, co własne wydaje się być podstawowym odruchem uczestników każdej kultury, wyrażającym się w śmiałym korzystaniu ze wspólnotowych narracji, instytucji i symboli. A jednak, podważenie roli i prawomocności znaków rozpoznawczych własnej formacji kulturowej stało się jednym z najważniejszych syndromów nowoczesnego świata zachodniego. Proces ów przebiegał stopniowo, prowadząc w końcu do sugestii, że symbole przynależności służą głównie temu, by narzucać je innym. Co może uczynić obarczony taką świadomością człowiek? Czy rozwiązaniem byłby wybór jakiejś innej kultury, religii, otoczenia społecznego, czy raczej projekt nowego, a-symbolicznego świata, w którym nie trzeba będzie wybierać? A może należałoby jednak próbować odnaleźć się na nowo w porzuconej przez siebie kulturze? Pytania te zostaną zadane w obecności — i przy udziale — dwojga wymienionych w tytule współczesnych polskich poetów. Najpierw jednak kilka uwag, odnoszących się do ideowego i wyobrażeniowego tła problematyki przynależności i obcości.

Stanisław Jasionowicz — dr hab., prof. Uniwersytetu Pedagogicznego w Krakowie, Instytut Neofilologii UP w Krakowie, Pracownia Badań Porównawczych nad Współczesną Kulturą Zachodnią; e-mail: stanislaw.jasionowicz@up.krakow.pl 


\section{Partycypacja, kontestacja, zawłaszczenie}

Podważenie przez europejskich symbolistów - owych prekursorów nowoczesności - tradycyjnych systemów kulturowych konotacji nie oznaczało jeszcze radykalnej kontestacji znaczeń własnej kultury, ale stanowiło próbę odwołania się do wartości symbolu, przekraczającej jego postrzeganie jako „znaku rozpoznawczego" konkretnej formacji kulturowej i uznanie go za niepoddającą się jakiemukolwiek lokalnemu zawłaszczeniu, wieloznaczną epifanię Niepoznawalnego $^{1}$. Warto zauważyć, że podniesienie na nowo przez francuskich i belgijskich artystów końca XIX stulecia symbolu do tak wysokiej rangi nie miało wymiaru jakiejś mistycznej krucjaty, a było po części krytyczną reakcją wobec efektów zawłaszczenia przez burżuazję religijno-kulturowych treści oraz znaczeń, wypracowanych przez społeczeństwo przedrewolucyjne i zredukowania ich do skostniałych, zakłamanych, „,filisterskich” form.

Czynnikiem, sprzyjającym postawie „stanięcia poza” jest sytuacja emigracji i poczucie „bycia wygnanym”. To często wymuszony okolicznościami, a czasem świadomie podjęty los wielu ludzi, pośród nich także artystów, poszukujących nowego języka sztuki poprzez odwołanie się do kategorii „obcości”. Europejscy twórcy artystycznych awangard początku XX wieku byli poniekąd takimi uciekinierami: zarówno z krajów ogarniętych światową wojną, podczas której ważyły się losy starej Europy, jak też ze swych „zatęchłych” burżuazyjnych domów w Paryżu, Brukseli czy Bukareszcie. Początkowo było to jedynie poszukiwanie „enklaw wolności”, pozwalających swobodnie poigrać z symbolami, które stawały się w ich oczach martwymi, fałszywymi znakami. Z czasem zaowocowało to próbami rozciągnięcia własnego stanu świadomości na cały zajmowany przez siebie obszar kulturowy z nadzieją przekucia owej inności w nową, wspólnotową jakość — swoistą międzynarodówkę pogardy wobec dotychczasowych sensów i znaków przynależności.

W swoim, opublikowanym w roku 1913, słynnym poemacie Strefa (Zone) Guillaume Apollinaire — ów kosmopolita o włosko-polskich korzeniach i poliglota o rozległych horyzontach kulturowych — ogłasza Francuzom swoje (a może: ich?) własne zniecierpliwienie „starą Europą”:

$\mathrm{Na}$ koniec starodawny ten świat ci się przejada

[...]

Grecka i rzymska starożytność twojego nie nasyci głodu

Tutaj starzyzną trąci już nawet widok samochodu

Religia się jedna została nowsza nad wszystko

Religia prosta pozostała jak hangar na lotnisku

1 W dalszej konsekwencji doprowadziło to jednak do zaprzeczenia samej „funkcji symbolicznej”. Na temat funkcji symbolicznej, por. np. prace Ernsta Cassirera i Carla-Gustava Junga. 
O chrześcijaństwo ty jedno w Europie zakwitasz świeżo

Najbardziej modernistycznym Europejczykiem jesteś ty Piusie X Papieżu

A ciebie którego dziś rano każde oko śledzi

Wstyd powstrzymuje od pójścia do kościoła i do spowiedzi

(Apollinaire 1975: 37)

Rozgorączkowanemu piewcy nowoczesności samochody zdają się być przestarzałe już w drugim dziesięcioleciu dwudziestego wieku, lecz jednocześnie Chrystus staje się dla niego „pierwszym lotnikiem”, a papież Pius X, przeciwnik aggiornamento - dynamicznym kontrapunktem dla wizji bezalternatywnej, kontestującej tradycję, nowoczesności. Apollinaire, zwany często odnowicielem liryki francuskiej, sugeruje możliwość zachowania przez nowoczesnego poetę więzi pomiędzy „dawnymi a młodszymi laty”, a istotą nowej poezji będzie twórcze czerpanie — „tu i teraz” — ze wszystkich dostępnych jej zasobów. U Apollinaire’a granica pomiędzy tym, co własne a tym, co „cudze” („obce”) staje się więc płynna, lecz chęć tworzenia „nowych symboli” w kolonialnej Francji, znajdującej się u szczytu swojej gospodarczej prosperity, podyktowana jest bardziej przekonaniem o konieczności dotrzymania kroku, przez wyobraźnię poetycką, wyzwaniom cywilizacji technicznej, niż chęcią całkowitej destrukcji dawnego świata.

Inni są bardziej radykalni w swoich poszukiwaniach „nowego”. W pochodzącym z roku 1946 wierszu Jacques'a Préverta, zatytułowanym Walka z aniotem (Le combat avec l'ange) samotny bohater szczególnej walki bokserskiej wykreowany jest na uczłowieczonego Chrystusa-buntownika, z góry skazanego na niesportowy nokaut ze strony wszechmocnej Władzy, reprezentowanej przez tajemniczego przeciwnika, wspieranego przez opresyjnych „nich” — francuskich „strasznych mieszczan”, znienawidzoną przez poetyckie ego poety tłuszczę popleczników katolickiego Boga Ojca:

\section{$[\ldots]$}

Cały ten mecz to szachrajstwo

I ledwie on się pojawi na ringu

W otoku błysków magnezji

Oni na całe gardło zaintonują TE DEUM

I jeszcze zanim wstaniesz z krzesełka w narożniku

Ogłoszą Twoją przegraną biciem we wszystkie dzwony

Rzucą ci prosto w twarz

Gąbkę przeklętą

I zanim zdołasz się jakoś dorwać do jego piórek

Rzucą się hurmem na ciebie

A wówczas on ci zada cios poniżej pasa

I zwalisz się jak długi 
Z ramionami pokracznie rozkrzyżowanymi

W trociny

I już nie będziesz mógł nigdy przespać się z dziewczyną

(Prévert 1978: 311)

Tak jednoznacznie ukazany podział ról, wynikający z chęci dostosowania przez anarchizującego poetę biblijnego motywu do potrzeb aktualnej polemiki społecznej - instrumentalne potraktowanie starotestamentowego motywu walki Jakuba z aniołem oraz chrześcijańskiego obrazu Chrystusowej męki - zaciera pierwotny sens przywoływanych scen. Jakkolwiek epizod z Księgi Rodzaju był od początku historii egzegezy biblijnej przedmiotem kontrowersji i licznych interpretacji wewnątrz formacji kulturowej, w której funkcjonował (i poniekąd funkcjonuje), to uznanie sytuacji Jakuba za analogiczną do sytuacji Chrystusa, „wysłanego na śmierć” przez Ojca i otoczonego nienawistnym tłumem jego popleczników (wyznawców), radykalnie pozbawia konkretne znaki kulturowe ich wewnętrznej logiki, wykorzystując jedynie ich zewnętrzny sztafaż w bieżącym sporze politycznym. Taki stosunek do symboli, funkcjonujących w jego własnej kulturze sprawia wrażenie poruszania się poety po obcym mu już terytorium. Przedmiotem kontestacji są tu oczywiście kody symboliczne chrześcijaństwa, lecz jednocześnie wiersz ten, jak zresztą cała twórczość Préverta, wyraża niechęć do jakichkolwiek mocnych („transcendujących”) znaków i narracji, postrzeganych jako narzędzia „symbolicznej przemocy”: w zamian artysta proponuje wizję znaków „niewinnych”, „neutralnych”, w postaci poetyckich obrazów codzienności oraz podstawowych, niezapośredniczonych ludzkich radości i trosk.

Już z końcem lat 50. dwudziestego wieku Roland Barthes postulował, by uznawać wszelkie systemy symboliczne i ich mityczne rozwinięcia za zawsze podejrzane „języki drugiego stopnia” (por. „langage(s) second(s)”), określając je jako „faszystowskie”, gdyż „zmuszają, by wybierać” (Barthes 2000; por. Barthes 1978). Twórca (poeta) nowoczesny, poszukujący swego miejsca w coraz bardziej obcym mu świecie jest wciąż rozdarty pomiędzy „buntem przeciw” a „buntem ku": już rewolucja francuska 1789 roku głosiła wolność od wszelkich znaków przeszłości, ale tworzyła zarazem nowy porządek, zawłaszczający wiele spośród symboli i narracji ancien régiméu. Kolejne realizacje idei, nakazującej zanegowanie dotychczasowych kodów kultury - marksizm, modernizm, idea światowej rewolucji - zmuszały przecież do dokonywania radykalnych wyborów: zmiany języka, wyparcia się pewnych kulturowych kodów, aby zastąpić je innymi, „właściwymi”.

Postulaty „oczyszczenia świadomości”, czy to za pomocą medytacji transcendentalnej, narkotyków, czy w akcie poetyckim znalazły swoją pełną ekspresję 
dopiero w dwudziestym wieku — w ruchach młodzieżowych lat 60. w Stanach Zjednoczonych, w krajach Europy Zachodniej i Środkowej oraz Ameryce Łacińskiej — ale i wtedy nigdy w całkowitym oderwaniu od historyczno-społeczno-kulturowo-politycznych uwarunkowań rejonu świata, w których się pojawiły. Wybór negacji coraz częściej znaczony jest jednak symbolami wspólnoty, będącymi zestawami signifiants, oderwanych od swoich signifiés. Oto na przykład dzieci kolejnego pokolenia zadowolonych bourgeois - młodzi paryscy buntownicy z maja 1968 roku głoszący, że odtąd „zabrania się zabraniać”, powołują się jednocześnie na czerwoną książeczkę Mao Tse Tunga — zawierającą doktrynę maksymalnego zniewolenia jednostki w oparciu o pseudonaukową ideologię zbawienia mas przez katorżniczą pracę.

W powojennej Polsce poetyka buntu i zaangażowania opierała się na dylematach oportunizmu i sprzeciwu, opowiadania się za „nową”, socjalistyczną, przywiezioną na obcych bagnetach ojczyzną lub kultywowania polskich symboli II Rzeczpospolitej w zupełnie nowym kontekście historycznym. $\mathrm{Z}$ początkiem lat 80. owa dychotomia sprowadzała się często do odpowiedzi na proste pytanie: „jesteś za Solidarnością czy za Partią”? Okres drugiej połowy lat osiemdziesiątych ubiegłego stulecia wraz z początkiem kolejnej dekady to z kolei czas, kiedy także niektórzy spośród młodych poetów spróbowali przezwyciężyć aporie tak rozumianej, dwubiegunowej wizji „bycia tu”. Charakterystycznym głosem przemówiło w tym czasie środowisko krakowskiego „bruLionu”. Ci młodzi Polacy nie wyemigrowali, zdecydowali się studiować historię polskiej kultury i literatury w starym uniwersyteckim mieście zamkniętego za „żelazną kurtyną” kraju Europy Środkowej, lecz jednocześnie chcieli znów wiosną, zamiast Polski, „wiosnę zobaczyć”. Powtarzając, w nowym kontekście, niektóre spośród gestów modernistów początku dwudziestego wieku, antycypowali oni dylematy artystyczne twórców pierwszych dekad następnego stulecia.

\section{Świetlicki, Gruszka-Zych: uniwersalne czy lokalne „znaki istnienia”?}

Dwoje poetów pokolenia lat 60. - Marcin Świetlicki i Barbara Gruszka-Zych to skupieni na kontemplacji własnych wewnętrznych stanów poetyccy egotyści, ale także wrażliwi obserwatorzy otaczającego ich świata. Świetlicki, uznający samego siebie za twórcę „trochę autystycznego" i podkreślający często swoją mizantropię oraz niechęć do świata, jest jednak mocno zaangażowany emocjonalnie w polską rzeczywistość. Gruszka-Zych, „otwarta na świat i ludzi” poetka, dziennikarka, sporo podróżująca reporterka, autorka książek o swoich „bliskich spotkaniach” z Czesławem Miłoszem i Wojciechem Kilarem, to autorka, dla której ważnym 
kontekstem twórczym są odkrywane przez nią i badane z perspektywy intymistycznej, znaki kulturowej tożsamości.

Gruszka-Zych i Świetlicki zetknęli się na krótko u progu swojej literackiej działalności, podczas organizowanych przez tygodnik „Na Przełaj” spotkań Klubu Młodych Autorów, jednak odtąd ich dalsze drogi przebiegają całkowicie odrębnie. Reprezentują dwa różne, choć komentujące się wzajemnie — jeśli nie komplementarne - światy odniesień, skojarzeń i znaczeń, a przede wszystkim, szczególny stosunek do symboli kulturowych, rozpatrywanych na tle znaków własnego istnienia.

Odwołanie się do cierpienia zdaje się być pierwotnym sposobem oznaczania przez oboje poetów parametrów własnego „bycia tu”. W wierszach Świetlickiego zdumienie faktem bycia wyraża się często jako doświadczenie fizycznego, namacalnego lęku. Ten punkt wyjścia, charakterystyczny dla nowoczesnej świadomości, stwarza ramy dla poetyckiego postrzegania świata w kategoriach zagrożenia. U Świetlickiego zdecydowanie dominuje skupienie na własnych przeżyciach egzystencjalnych, a jego podmiot poetycki (być może w imię swej męskiej powściągliwości) prawie nigdy nie odnosi się do fizycznego cierpienia innego człowieka. W twórczości Gruszki-Zych naturalne pytania egzystencjalne nie przybierają tak dramatycznie brzmiących tonów, choć w jej utworach nie brakuje odniesień do traumatycznych wydarzeń, jak choroba, pobyty w szpitalu i śmierć bliskich. Jej relacja ze światem jest warunkowana przez kategorię współczucia i solidarności z innymi w ich lękach i cierpieniach — a owa solidarność zdaje się dotyczyć także podmiotu lirycznego, który oswaja własne cierpienie, obserwując je z bliska ze szczególnym, można by rzec, reporterskim, zainteresowaniem.

\section{Być mężczyzną, być kobieta, mówić „tym” językiem: pierwszy krąg przynależności}

Oboje poeci znacząco często odwołują do doświadczenia własnej tożsamości płciowej oraz wyrażają przywiązanie do własnego języka. To kolejne znaki przynależności, doświadczane przez Świetlickiego i Gruszkę-Zych. Akceptacja własnej płci oraz waga, jaką każde z nich przywiązuje do „innego” w sensie płciowym, wiąże się także z dostrzeganiem kulturowych znaków, wyrażających tę relację.

Świetlicki w naturalny sposób, a czasem nieco demonstracyjnie (gdy pisze na przykład: „Mieszkam z tobą nie w ramach parytetu, kobieto” — Świetlicki 2016: 88) manifestuje swoją męską naturę w relacji z fascynującą go (czy tylko erotycznie?) kobiecością. „Bycie z kobietą” oznacza dla niego „stan naturalny”, a zarazem ideał harmonii, do którego wciąż dąży jego poetycki podmiot: 
W innym wszechświecie spotkałbym

siedmiogłowego woła

ośmiopenisowego tygrysa,

mógłbym się tam z nim związać.

Spokojnie.

Zanika młodzieńczy problem.

No i normalnie znajduję kobietę.

No i normalnie radzę sobie.

Spokojnie.

Moja płciowość

określiła się.

A nad tym wszystkim stoi

Pan Bóg

(Świetlicki 2013: 71, Pan Bóg)

Synonimem, a może raczej symbolem egzystencjalnego i kulturowego zakorzenienia staje się dla Świetlickiego relacja, której punktem odniesienia jest kobieta, jako fascynująca „obca” — znak czy też ślad możliwości Ładu, nadzieja na porządek istnienia.

Także Barbara Gruszka-Zych śmiało i z niekłamaną satysfakcją zagłębia się w meandry uczuć, erotycznych fascynacji, radości i niepokojów swej kobiecości. Zmysłowość, namiętny stosunek do rzeczywistości Gruszki-Zych wyraża się między innymi w pragnieniu harmonii, ukazywanej jako „rozpłynięcie się" w drugim:

ciałem w ciało

jak kamieniem w wodę

nie znajdziesz śladu

że było ich dwoje

(Gruszka-Zych 1997: 101, ***)

Nie oznacza to jednak dążenia do zatarcia, czy też negacji własnej tożsamości: miłość i potrzeba erotycznego spełnienia wyzwalają w poetce siłę, pozwalającą jej śmielej „przejrzeć się” w swoim doświadczeniu kobiecości i umocnić w ten sposób swoją samoidentyfikację:

zacząłeś mówić o kobiecie i mężczyźnie

dotąd nie przyznawaliśmy się do tego

dlatego dziś widzimy się

pierwszy raz

(Gruszka-Zych 1997: 38, ***) 
W przypadku Świetlickiego, jego dążenie do „bycia z kobietą”: „[...] przejdziemy przez siebie / w lepsze, gorące kraje, bo istnieją, skoro / ty zaistniałaś i ja już istnieję ..." (Świetlicki 2011: 148, Pogo), owo marzenie o spełnieniu jako swoistej „przedustawnej harmonii” powiązane jest z potrzebą „przeniknięcia się”, ale też przyjęcia tego, co owa „inność” oferuje - darem tym jest możliwość samoidentyfikacji: „ona mi daje życie / ona mi je robi” (Świetlicki 2013: 57, O). Jednocześnie harmonia ta narażona jest na liczne niebezpieczeństwa, do których należą zrytualizowane praktyki życia rodzinnego:

Dla mamy, żony, mamy żony, taty, taty żony i dzieci, pani dzieci ze szkoły siostry dzieci ze szkoły, golą się i robią w swojej robocie swoją robotę i jadą na długi weekend z mamą, żoną, mamą żony $[\ldots]$

Lecz nagle pęka śrubka, misterna konstrukcja w tej chwili grozi zawaleniem! Ale natychmiast przy pomocy żony, mamy żony i taty, brata żony, pani doktor i kilku przyjaciółek żony, pęknięcia jakoś daje się zasłonić, dalej się można golić, robić, spokój kazirodczy (Świetlicki 2013: 11, Śrubka)

Społeczne role mężczyzny, także widziane na tle nierzadkiej dominacji (a przynajmniej silnej pozycji) kobiet w polskiej rodzinie, zdają się go uwierać: pisząc o „zasłonięciu”, a nie na przykład „zabliźnieniu”, „naprawie”, czy choćby „załataniu” pęknięcia w grożącej zawaleniem rodzinnej konstrukcji poeta daje poza wszystkim wyraz swojemu niepokojowi, związanemu z osłabieniem roli mężczyzny we współczesnej rodzinie (a może w domu, zdominowanym przez kobiety?). Pytając jednocześnie o samą rodzinę jako instytucję społecznego przymusu, uznaje ją za jedną z protez, nieudolnie, jego zdaniem, eufemizujących dramat przemijania i śmierci:

[...] w cukrze jajo robaka, a pościel pokryta grzybem, grzyb zakrył inicjał na pościeli, co to ją mama albo inna kobieta $\mathrm{z}$ rodziny, jakiej rodziny? Jest tylko grzyb, robak (Świetlicki 2011: 117, To mnie umiera) 
Macierzyństwo i ojcostwo pozostawiło oczywiście swe ślady w poetyckim imaginarium obojga poetów, ale u każdego z nich w nieco odmienny sposób.

Gruszka-Zych akceptuje swoje macierzyństwo i obserwuje siebie jako matkę w całym przebiegu historii swojej relacji z dziećmi - począwszy od wiersza, pochodzącego z jej debiutanckiego tomiku: „między wilgocią sutki / a uchylonymi snem ustami / leniwa niteczka śliny / pępowina / którą znów znalazła / matka" (Gruszka-Zych 1994: 26, ${ }^{* * *}$ ) po ten, opublikowany w roku 2015: „chcę się wybrać z synem na spacer / pytam nieśmiało kiedy będzie miał czas / kiedyś to on mnie prosił żebym z nim wyszła" (Gruszka-Zych 2015: 26, *** — synowi Tymoteuszowi). Jej poetyckie obserwacje, odnoszące się do zmieniających się z czasem relacji z własnymi dziećmi są zarazem introspekcją jej stosunku do własnego przemijania.

Świetlicki, w nielicznych wierszach inspirowanych ojcostwem, zdaje się wyrażać zniecierpliwienie koniecznością spełniania rodzinnych rytuałów, a także niepokój, związany z możliwością stania się składnikiem „najmniejszej komórki społecznej” oraz uczestnikiem tak zwanego „procesu wychowawczego". W jego wierszu, zatytułowanym Jowejek można jednak odnaleźć echo egzystencjalnych pytań zadawanych przez poetkę: „Żabka. / Kaczuszka. / Kajecik. / Ślizgawka. // Gojonczka. / Ziułtaczka. / Jowejek. / Jowejek. // A potem bryła ciała wypchnięta w przestworza" (Świetlicki 2011: 423, Jowejek).

\section{Akulturacja czy a-kulturacja? (Drugi krąg pytań o „inność”)}

Poszukiwanie sposobów dostosowania się jednostki do zastanej kultury — oto chyba najkrótsza definicja procesu akulturacji. Tymczasem ważnym składnikiem obecnego stadium zachodniej formacji kulturowej staje się zjawisko, które można określić mianem a-kulturacji — dążenia do uzyskania swoistego „zerowego stopnia” doświadczenia „bycia tu”. Stwierdziliśmy już jednak, że zarówno w skali pojedynczego życia, jak i w skali całych społeczeństw ten utopijny stan nigdy nie trwa zbyt długo, prowadząc stopniowo do ponownego „zagospodarowywania” tak opróżnionej przestrzeni. W roku 2011, we wstępie do pełnego wydania swoich napisanych do tej chwili wierszy, Świetlicki wygłosił następującą deklarację:

Poezję robi się przeciw. Przeciw Instytucji, jakkolwiek by się nie nazywała. Przeciw każdej władzy. Przeciw niesprawiedliwości. Przeciw głupocie. Przeciw złym ludziom. Poezja jest ryzykiem. Poezja jest odwagą. Poezja jest niebezpieczna. Wszystko inne to łatwo przetłumaczalne na wiele języków świata bajdurzenie. I tyle. (Świetlicki 2011: 5, Wstęp) 
Ów wyartykułowany przez pięćdziesięcioletniego poetę, nieco naiwnie brzmiący manifest przypomina $\mathrm{z}$ pozoru anarchistyczny wydźwięk napisanego wiele lat wcześniej wiersza Brejkanie, rozpoczynający się od słów: „Dzisiaj — / dostałem list od Papieża. / [...] / Pisze — / pisze, że we mnie wierzy. // Brejkam wszystkie rule. / Brejkam rule" (Świetlicki 2011: 282, Brejkanie), w którego drugiej części czytamy jednak:

Chwalę imię Pana.

W Babilonie.

Chwalę imię Pana.

Za pieniądze.

Wasze - czyste — niezależne

— pieniądze.

Żona.

Dzieci.

Dom postawić.

W Babilonie.

Żona.

Dzieci.

Wanda.

Mieczysławek.

Halina.

Brejkam wszystkie rule.

W Babilonie.

Wasze - czyste

— niezależne pieniądze -

(Świetlicki 2011: 282-283, Brejkanie)

„Babilon”, „korporacja”, „supermarket” to jednak nie tylko topoi kontrkulturowej świadomości Stanów Zjednoczonych, Niemiec czy Francji, ale odkrywanie „tu”, „u nas”, „za oknem”, niepokojących krajobrazów nowej tożsamości. Częste odwoływanie się przez Świetlickiego do tych, kształtujących współczesne kulturowe sensy miejsc wspólnych ma wydźwięk „antyukładowy”: poeta ośmiesza „skarlenie” ambicji i aspiracji młodych ludzi (pisze z perspektywy mężczyzny), które sprowadzają się do wyobrażeń o „małej stabilizacji” — „żony, dzieci, własnego dachu nad głową”, wymagającej przekierowania wyobraźni na tory „korporacyjne”. Chociaż poeta nie pyta o przyczyny takiego stanu rzeczy, to jednak z niepokojem dostrzega proces degradacji życia społecznego, ograniczającego się do masowej konsumpcji jego standardowych, zunifikowanych produktów.

Także Barbara Gruszka-Zych stosuje poetycką taktykę „oczyszczenia” swojej relacji ze światem. Jej strategia nie jest jednak zbudowana na zasadzie dychoto- 
mii, lecz polega na odszukiwaniu „znaków sensu” w subtelnych sygnałach, jakie wychwytuje ona z otaczającego ją świata rzeczy i zdarzeń, ale przede wszystkim tych, które otrzymuje od innych ludzi. Niechętnie definiuje istotę swojej twórczej praktyki, jednak w wierszu, opublikowanym w latach 90. stwierdza, że poezja jest działalnością „pomagają[cą słyszeć tych którym brakło głosu” (Gruszka-Zych 1997: 23, wiersz). Bunt nie jest jej naturą, choć daleka jest od postawy bierności; jej protest przeciwko „złym praktykom” świata wyraża się w postawie, którą można by określić jako amplifikację głosu małych znaków. Wychodząc od najprostszych, najbardziej „ubogich” symboli, stopniowo rozwija je w aktach poetyckiej hermeneutyki, przełamując ich jednostkowy, efemeryczny wymiar i otwierając je na intersubiektywną nadzieję sensu.

\section{„Jaka ojczyzna”? „Jaka Polska”? — trzeci krąg pytań o obcość i przynależność}

Wiele wierszy Marcina Świetlickiego ma w tytule słowo „Polska”. W typowy dla siebie, przewrotny sposób poeta mówi, że właściwie cała jego twórczość jest polityczna. Jednak ojczyzna to obszar symbolicznych konotacji, który wydaje mu się nad wyraz niebezpieczny, szczególnie z chwilą, gdy zaczyna się definiować poprzez jakiekolwiek, nacechowane emocjonalnie znaki wspólnoty:

Państwo świętuje i świętują państwo,

Obchody i odchody.

Podchody z pochodniami na dnie

(Świetlicki 2013: 22, Polska 5)

Świętują „oni”, cieszący się swoim poczuciem „bycia razem” (ergo: przeciw komuś?), podczas gdy samotne „ja” (jak w przywołanym wcześniej wierszu Jacques'a Préverta) jest tu czynnikiem obcym, narażonym na potencjalną agresję „zaangażowanego” tłumu — zdaje się sugerować poeta, serwując czytelnikowi wizję złowrogich, hitlerowskich marszy i zrównując je w dość pospiesznym poetyckim geście z wszelkimi przejawami wspólnotowej tożsamości.

Świetlicki raz po raz zmaga się w swoich tekstach z obsesją „fałszywych znaków" - jak we wczesnym, pochodzącym z roku 1988 roku wierszu, zatytułowanym Dla Jana Polkowskiego (Świetlicki 2011: 61-62)2. Pozornie lustrzanym odbiciem tego szeroko dyskutowanego utworu jest wiersz Jechać, odnoszący się do powrotu do Polski Adama Zagajewskiego na początku lat 2000 (patrz

2 O dyskusji, jaka toczyła się w latach 90. na temat politycznego zaangażowania poezji polskiej i postawy Marcina Świetlickiego w okresie „przełomu” roku 1989 pisał na przykład Dariusz Pawelec (1999). 
Zagajewski 2003). Wydaje się, że w obu przypadkach chodzi bardziej o niebezpiecznie egzaltowany ton literackich wypowiedzi Polkowskiego i Zagajewskiego, a nie jedynie o tropienie „fałszywych znaków przynależności”. Poeta zdaje się zresztą nie dostrzegać różnicy pomiędzy postawami obu twórców, stawiając jakby znak równości pomiędzy podniosłym tonem poezji pierwszego, a napuszonym samozadowoleniem drugiego z nich.

W twórczości Gruszki-Zych niewiele jest jednoznacznych odwołań do ojczystego kraju czy polemicznych tonów, odnoszących się wprost do polskiej rzeczywistości polityczno-społecznej. Jej „bycie tu” nie wymaga być może dodatkowych uzasadnień, opartych na wyraźnie eksponowanym kodzie kulturowym. A jednak, poetka wyraża ostrożne zaufanie wobec symboli, budując je na gruncie przejawów autentycznego doznania solidarności z innymi ludźmi, niezależnie od tego, czy skłonni są porozumiewać się z nią za pomocą wspólnego systemu znaczeń. Do najważniejszych oznak prawdy doświadczenia należy według niej troska o innych, ale także pytanie o sens „krwi umarlych”. Świadczą o tym jej liczne wiersze „szpitalne” oraz tomik Szara jak wróbel, będący poetyckim zapisem towarzyszenia umierającemu ojcu, a także opublikowany w portalu społecznościowym wiersz, poświęcony górnikom z kopalni Wujek: „kiedy ich mordowali / samoloty latały nad Katowicami / 16 grudnia była zimna noc / jak serca tych co wydali rozkaz / czerwona część flagi / napełniła się krwią jak worek / do transfuzji tylko po co / Polsce krew nieżywych" (Gruszka-Zych 2016: ***). To właśnie na gruncie solidarności w obliczu „mocnych” doświadczeń jednostki buduje się, zdaniem poetki, przestrzeń mocnych, wspólnotowych znaczeń.

Żadne z dwojga poetów nie wyraża potrzeby ucieczki do jakiegoś innego świata, nie pragną oni przynależeć do innej przestrzeni geopoetyckiej, niż ta, która od półwiecza kształtuje ich doświadczenie. Urodzoną i dotąd mieszkającą w Czeladzi, często podróżującą poetkę, „biorą [...] w ramiona coraz węższe uliczki / małego miasta" (Gruszka-Zych 2007: 37, ***); Świetlicki chłonie kolejne „klimaty” zamieszkiwanych przez siebie dzielnic Krakowa, odnajdując się za każdym razem w ścisłych ramach tego, co rozpoznawalne, o czym zaświadcza na przykład jego tomik Delta Dietla ${ }^{3}$. „Miniojczyzny” obojga tworzą bezpieczne środowisko naturalne ich poetyckiej wyobraźni, będąc poniekąd mikrokosmosem (kontestowanej w przypadku Świetlickiego) szerszej perspektywy przynależności.

Eksploatacja wizerunku „bycia obcym u siebie” wciąż narażona jest na próbę rzeczywistości. Niezależnie od indywidualnie warunkowanych doświadczeń, sympatii i idiosynkrazji, oboje wybierają „tu i teraz” swojej egzystencji, by mozol-

3 Poeta zarzeka się, że nie lubi podróży i twierdzi, że za granicą nie napisał ani jednego wiersza oraz, że poza Polską czuje się obco - patrz wywiad promujący tom Drobna zmiana, opublikowany 9 listopada 2016 [online]. Dostęp: https://facebook.com/marcinswietlickiINFO [20.12.2016]. 
nie oswajać się z tym, co każde z nich mogłoby uznać za własne. Świetlicki czyni tak nawet wtedy, gdy pisze: „[... ] / Żadne hasła, żadne inicjały i żadne symboliczne obrazki / nie zakrywają mnie i dlatego zupełnie / nie mogą dojść kim jestem / [...] Świat nie oferuje / niczego oprócz blasku. Konkrety pierzchają. / Trzymam się papierosa, żeby się nie zgubić" ('́wietlicki 2016a: Noca z sierpnia na wrzesień).

\section{Dokąd pójść? Ślady i znaki transcendencji}

W poezji Marcina Świetlickiego znajdujemy zaskakująco wiele odniesień do chrześcijańskich symboli religijnych. Bóg Świetlickiego „porzuca czasem szachy” i z zaciekawieniem "wygląda zza chmury” (Świetlicki 2014: 123, Pierwszy dzień średniowiecza $)^{4}$; bawi się ludzikami jak chłopiec żołnierzykami w dziecinnym pokoju (między innymi mrowiącymi się w dole „polaczkami”), etc. Jeśli nawet jest figurą kulturową - jako Bóg Ojciec z brodą ze sklepienia barokowego kościoła, której powierzchowne atrybuty stają się pretekstem dla poetyckiej refleksji na temat hierarchii społecznych znaków - to jednak, jakoś, przewrotnie, ,jest”. Z pozoru całkowicie odseparowany od swych „poddanych”, synonim dyktatorskiej władzy, a jednocześnie łaskawy dawca przywilejów („,...] ty wypadłeś poza / mój dywan, nie dla ciebie drukuję gazety / i kręcę filmy, nie dla ciebie mielą / pieniądze moje banki, nie ciebie ochrania / moja policja, już nic cię nie chroni” (Świetlicki 2011: 10, Piosenka Boga) — może dostrzeże jednak, podniesie i postawi z powrotem na dywanie?

Świetlicki zdaje się prowadzić swoistą grę z Transcendencją, której (o)znaki drażnią go, i kuszą zarazem. Wprawdzie niestrudzenie deklaruje swą niewiarę w możliwość zaufania „mocnym” symbolom i mitom, jednak poszukuje sposobów ujęcia ledwie przeczuwanych sygnałów Mocy, nierzadko czyniąc to w konwencji, porównywalnej do sformułowań mistyki apofatycznej:

Ujść sobie, ubyć z grobu, odmówić, obmyć obie dłonie, wydobyć sobie siebie z siebie, dobić złe ostatecznie, oby. (Świetlicki 2011: 410, Tak się modlit)

Jeśli rzeczywistość daje „zbyt mocne” znaki — poeta wzmaga swą czujność, gdyż mogą one zostać natychmiast włączone w grę emblematów, łatwo wymiennych na aktualną polityczną monetę:

4 Wersja wiersza Pierwszy dzień średniowiecza, śpiewana przez autora z zespołem Świetliki patrz Świetlicki 2015a: 123. 
To ten sam wiatr, który poruszał stronicami Księgi

Przywiał w tej chwili Hostię w ręce Prezydenta

To te same, uparcie te same trupięgi,

To ten sam supermarket i to ten sam cmentarz ${ }^{5}$.

(Świetlicki 2015: 26, To ten sam wiatr)

Powraca pytanie: czy poeta obawia się jedynie — nieuniknionej przecież — możliwości doraźnej manipulacji znakami-symbolami społecznej i religijnej przynależności, czy też kwestionuje samą tęsknotę współczesnego człowieka do znaków transcendencji?

Jeśli Barbara Gruszka-Zych wybiera często za przedmiot swej twórczości symbole możliwie najmniej zapośredniczone (najmniej obarczone perswazyjnymi, jednoznacznymi sensami), to stara się w ten sposób odnaleźć trwałe podstawy własnego stosunku do tradycji i do związanych z nią kodów kulturowych. W jej wierszach relacja ta nie zawsze i nie od razu staje się elementem doświadczenia wspólnotowego: nawet bycie chrześcijaninem i znalezienie się w miejscu kultu nie gwarantuje ani osobistej, ani dzielonej z innymi epifanii transcendencji:

weszłam do kościoła

żeby się pomodlić czyli polecić Bogu

moich bliskich było ich wielu

jak muzyków w orkiestrze

właśnie jakaś orkiestra miała tu próbę

przed wieczornym koncertem

dlatego przeniesiono tabernakulum

i tam gdzie błyszczała hostia zapadła ciemność

szukajcie powtarzał dyrygent co chwilę

przerywając smyczkom tak że muzyka

rwała się jak moja modlitwa

aż wreszcie zawisła ciszą w pełnym kościele

(Gruszka-Zych 2008: 25, ***)

Swoją przynależność do „kodu transcendencji” Gruszka-Zych wydobywa najczęściej z gestów i znaków pozornie „odsymbolicznionej” codzienności:

podałam tacie ciasto obsypane orzechami ziemnymi

$[\ldots]$

5 Czy pomiędzy wszystkimi symbolami, tworzącymi się (lub wytwarzanymi) w kontekście władzy poeta stawia matematyczny znak równości? Wszak w żadnym ze swych wierszy nie odniósł się on na przykład do interesującej, z perspektywy hermeneutyki symboli, próby stworzenia „nowej symboliki” władzy w postaci wizerunku czekoladowego orła i uroczystości, towarzyszących jego prezentacji? 
zamiast słów jedzenie po kawałku dopełnianie siebie światem upieczonym na blasze w czworobocznej formie uniesionym przez tatę do ust w pokornym geście komunii (Gruszka-Zych 2000: 24, ${ }^{* * *}$ )

Z kolei w wierszu, w którym niewinne, skupione przejęcie dziewczynki przed ołtarzem zestawione jest z prawdą milczącego, ulotnego piękna natury, jeszcze dobitniej realizuje się zasada sprzężenia zwrotnego pomiędzy znaczonym i znaczącym symbolu, relacja oparta jednocześnie na prawie analogii i partycypacji:

Dziś o świcie każda gałązka jakby przystępowała do pierwszej komunii w delikatnej bieli szadzi

(Gruszka-Zych 2015: 23, ***)

\section{Droga pośród znaków}

Pomimo wszelkich dzielących ich różnic, jednym ze wspólnych mianowników twórczości obojga poetów jest podejmowana przez nich próba redefinicji ich stosunku do własnej kultury jako poszukiwanie tego, co jawi im się jako własne. W przypadku Marcina Świetlickiego niechęć do integracji (,jaka rodzina?”, ,jaki Bóg?” ,jaka ojczyzna?”) jest gestem obronnym wobec atakującego zewsząd natłoku znaczeń, domagających się „podjęcia decyzji”, opowiedzenia się „za” lub „przeciw”. Spierając się poetycko z zastanymi symbolami kultury, Świetlicki chciałby zarówno zaprotestować przeciwko ich skostnieniu, jak i ukazać — poprzez zabieg swoistej wiwisekcji — efekty ich ponowoczesnej, migotliwej efemeryczności. Na tej (pozornej?) niekonsekwencji buduje on niejasną, głęboko skrywaną nadzieję odnalezienia jakichkolwiek „znaków prawdziwych”.

Można by sądzić, że powyższe dylematy w znacznie mniejszym stopniu oddziałują na poetykę Barbary Gruszki-Zych. Jednak i ona prowadzi swoistą grę z symbolami, którym daje jedynie ograniczony kredyt zaufania: praktyka ta polega na intuicyjnym wychwyceniu tych, które wydają się być mocniejszymi, niż inne, a następnie poddaniu ich „próbie trwałości” w świetle kolejnych egzystencjalnych zdarzeń.

${ }^{6}$ Jego książka poetycka z roku 2016, zatytułowana Drobna zmiana zdaje się częściowo modyfikować taką postawę, wyraźniej niż dotąd określając miejsce poety w przestrzeni aktualnej (w czasie, gdy pisał wiersze tego tomu) polskiej debaty medialno-politycznej. Autor potwierdza to po części w rozmowie, promującej jego tomik poetycki, deklarując między innymi, że „człowiek musi wybierać”, po chwili stwierdzając z kolei, że „nie wie[m], komu wierzyć” — rozmowa z Marcinem Świetlickim, przeprowadzona w wydawnictwie a5, 9 listopada 2016 roku (Świetlicki 2016b). 
Zajmowana przez Świetlickiego i Gruszkę-Zych indywidualistyczna postawa wobec znaków, jakie wysyła im świat, wyraża się w podejmowanych przez nich próbach odróżnienia symboli istotnych, które nie poddają się dyktatowi chwilowego, koniunkturalnego sensu od symboli skarlałych - kuszących swym blichtrem, lecz istotowo fałszywych. Wbrew jednoznacznej diagnozie współczesnej sztuki, jaką proponuje Jean Baudrillard i którą aprobująco cytuje Zygmunt Bauman („Wizje artysty nie przedstawiają, lecz symulują — zaś „symulacja odnosi się do świata pozbawionego odnośników, świata, w jakim wszystkie odnośniki wyginęły" (Baudrillard, cyt. za: Bauman 2000: 184), ani Marcin Świetlicki, ani Barbara Gruszka-Zych nie symulują swojej relacji ze światem, ale szanują łączącą ich z nim więź. Nie porzucają też swoich siedzib, choć ceną jest nieustający trud oswajania się z tym, co własne.

\section{BIBLIOGRAFIA:}

Apollinaire Guillaume. 1975. Wybór poezji. Oprac. Jerzy Kwiatkowski. Warszawa: Ossolineum. Strefa. Przeł. Adam Ważyk. S. 37-48.

Barthes Roland. 1978. Leçon: leçon inaugurale de la chaire de sémiologie littéraire du Collège de France : prononcée le 7 janvier 1977. Paris: Le Seuil.

Barthes Roland. 2000. Mitologie. Przeł. Adam Dziadek. Warszawa: Wydawnictwo KR.

Bauman Zygmunt. 2000. Ponowoczesność jako źródto cierpień. Warszawa: Wydawnictwo Sic!.

Gruszka-Zych Barbara. 1994. Teren prywatny. Katowice: Videograf.

Gruszka-Zych Barbara. 2000. Zapinajac kolczyki. Katowice: Parol.

Gruszka-Zych Barbara. 2007. Ile kosztuje tąka. Katowice: Biblioteka Śląska.

Gruszka-Zych Barbara. 2008. Muchy i ludzie. Katowice: Księgarnia św. Jacka.

Gruszka-Zych Barbara. 2015. Przyrzad do uzdatniania wody. Wrocław: Wydawnictwo Astrum.

Gruszka-Zych Barbara. 2016. Górnicy z kopalni Wujek. [online]. Dostęp: https://facebook.com/barbara.gruszkazych, wpis z 13 grudnia 2016 [20.12.2016].

Pawelec Dariusz. 1999. Oko smoka. O wierszu Marcina Świetlickiego „Dla Jana Polkowskiego". W: Kanonada. Interpretacje wierszy polskich (1939-1989). Red. Aleksander Nawarecki. Katowice: Wydawnictwo Uniwersytetu Śląskiego. S. 168-174.

Niewiadomski Andrzej. 2014. Dlaczego skwery sa idealnie kwadratowe? Przypisy do „Dla Jana Polkowskiego” po ćwierćwieczu. „Ruch Literacki” 2014, z. 6. S. 625-639.

Prévert Jacques. 1978. Walka Jakuba z aniotem. Przeł. Roman Kołoniecki. W: Hugo Friedrich. Struktura nowoczesnej liryki. Przeł. i wstępem opatrzyła Elżbieta Feliksiak. Warszawa: Państwowy Instytut Wydawniczy. S. 311. 
Świetlicki Marcin. 2011. Wiersze. Kraków: Wydawnictwo emg.

Świetlicki Marcin. 2013. Jeden. Kraków: Wydawnictwo emg.

Świetlicki Marcin. 2015. Delta Dietla. Kraków: Wydawnictwo emg.

Świetlicki Marcin. 2015a. Zto, te przeboje. Piosenki 1992-2015. Kraków: Wydawnictwo emg.

Świetlicki Marcin. 2016. Drobna zmiana. Kraków: Wydawnictwo a5.

Świetlicki Marcin. 2016a. Nocą z sierpnia na wrzesień. [online]. Dostęp: https://facebook.com/marcinswietlickiwiersze [1.09.2016].

Świetlicki Marcin. 2016b. Rozmowa z Marcinem Świetlickim. [online]. Dostęp: https:// facebook.com/marcinswietlickiINFO [18.12.2016].

Zagajewski Adam. 2003. Powrót. Kraków: Znak.

Stanistaw Jasionowicz

\title{
NATIVE STRANGERS? MARCIN ŚWIETLICKI AND BARBARA GRUSZKA-ZYCH FACING SIGNS OF BELONGING
}

\author{
(summary)
}

The article is a reflection on the symbols through which the modern experience of cultural belonging is expressed and on the motivations behind their contestation. Examples of selected themes that Marcin Świetlicki and Barbara Gruszka-Zych explore in their writing are used to examine the poetic quest to overcome feelings of alienation in one's own cultural milieu. In spite of the differences between the two poets, both address the problems facing the contemporary consciousness of Western man, split between the desire to complete the process of deconstructing his own universal "identifying signs" and the need to creatively explore the process of symbolization itself.

The issue of "internal acculturation," as a particular case within the topic of acculturation as a whole, is also correlated to examples drawn from Francophone poetry.

\section{KEYWORDS}

Marcin Świetlicki; Barbara Gruszka-Zych; contemporary Polish poetry; French poetry; sign; symbol; belonging; alienation; culture; acculturation; a-culturation 

Prace Polonistyczne, seria LXXII, 2017

ISSN: 0079-4791; e-ISSN: 2450-9353

DOI: $10.26485 / \mathrm{PP} / 2017 / 72 / 4$

Dorota Samborska-Kukuć

\section{ONIRYCZNA ANTYCYPACJA KORNELA FILIPOWICZA}

\section{SŁOWA KLUCZOWE}

Filipowicz Kornel; oniryzm; akulturacja

Marcinowi

[...] jestem tylko widzem, który patrzy, pamięta i zapisuje to, co się przed jego oczami rozgrywa, bliżej lub dalej, w czasie lub przestrzeni [...].

K. Filipowicz, Statość uczuć

Sen [...] tylko przedstawia, może śmieszyć, zasmucać lub przerażać nie formułuje jednak żadnych wniosków.

K. Filipowicz, Nike

Anna Sobolewska słusznie zauważyła, że w prozie Kornela Filipowicza uobecnia się szczególna, niekreacyjna odmiana oniryzmu, to jest obiektywny, rzeczowy zapis snu albo relacja ze snu, który „zachowuje swoją autonomię i tajemnicę” (Sobolewska 2000: 47-48; por. Lipowski 2005: 457). W dorobku autora Romansu prowincjonalnego wiele jest utworów, które ten rodzaj ujmowania świata reprezentują ${ }^{1}$; w autotematycznych wypowiedziach pisarza stanowią one

Dorota Samborska-Kukuć — prof. dr hab., Zakład Literatury Pozytywizmu i Młodej Polski, Instytut Filologii Polskiej i Logopedii, Wydział Filologiczny, Uniwersytet Łódzki, ul. Pomorska 131/133, 90-236 Łódź; e-mail: ddsk@wp.pl

1 Są to m.in. opowiadania z tomów: Koncert f-moll, Między snem a snem, Rozmowy na schodach. 
osobistą formę konsolacyjną. Jednym z takich modeli onirycznych jest napisany (lub skończony) w roku 1979 utwór Gdy przychodza we śnie, zamieszczony w tomie Koncert f-moll $i$ inne opowiadania $(1982)^{2}$, gdzie sąsiaduje z tekstami o podobnej proweniencji. Jerzy S. Ossowski, kategoryzując moduły ideowo-artystyczne przejawiające się w pisarstwie Filipowicza, kwalifikuje opowiadanie do grupy tekstów reprezentujących „paradygmat stosunków międzyludzkich” (Ossowski 2000: 236), w którym świat przeżyć wewnętrznych protagonisty jest filtrem rzeczywistości. Gdy przychodza we śnie to jednak nie tylko literacka rekonstrukcja marzenia sennego, ale rodzaj wizji. Jej treścią jest proces migracyjny i akulturacyjny uchodźców (lub wychodźców) z bliżej nieokreślonych krajów afroazjatyckich. Ich pojawienie się stwarza dla narratora szczególną sytuację egzystencjalną i etyczną ${ }^{3}$.

Niewielu krytyków komentowało ten niełatwy interpretacyjnie tekst. Dziś, w dobie promowania, skądinąd chwalebnych, postaw otwartości, szacunku i tolerancji wobec Innego, jako prewencji dyskryminacji oraz przezwyciężania stereotypów i klisz, w dobie akcji afirmatywnych, utwór Filipowicza — sen o zagrożeniu multikulturowością - może wydać się niepoprawny politycznie, a nawet niecenzuralny. Choć, co warto w tym miejscu zaznaczyć, opowiadanie Gdy przychodza we śnie należy do tych tekstów Filipowicza, o których Stanisław Balbus napisał, że:

są w stanie sprostać najbardziej sprzecznym formułom interpretacyjnym; [...] formuły te równocześnie znajdują w nich i rzeczywiste potwierdzenie, i równie rzeczywiste zaprzeczenie $[\ldots]$ proza ta może równocześnie różnym osobom [...] wydawać się naiwna i wyrafinowana, [...] realistyczna i symboliczna, [...] deklaratywna i ironiczna. Proza ta bowiem jest zarazem i taka, i taka. Pozwala się rzeczywiście czytać na różne sposoby. Istota jej spoczywa wszakże w tym, że należy ją czytać równocześnie „na różne sposoby”. Nakładać te sposoby podczas rozumiejącej lektury. (Balbus 1999: 253)

Można by więc zobaczyć tekst Filipowicza jako pewną transgresję wspomnień inspirowanych obozową traumą w duchu Różewiczowskiego Krzyczatem w nocy, do czego skłaniałyby niektóre detale snu, nie byłaby to jednak interpretacja wyczerpująca. Stanisław Rogala, odwołuje się do podobnych asocjacji, widząc

2 Opowiadanie miało jeszcze przedruki w innych tomach, m.in. w Rzadkim motylu z roku 1985, do którego wybierała teksty Wisława Szymborska.

3 W tomie znajduje się jeszcze inne opowiadanie (umieszczone po Gdy przychodzq we śnie) o tematyce migracyjnej: Modlitwa za odjeżdżających. Jest to rozgrywająca się w latach sześćdziesiątych XX wieku historia rugowania ewangelików do Niemiec. Filipowicz podejmował (być może w związku ze swoim pochodzeniem z terenów kresowych) tematy dotykające akulturacji. Oprócz wspomnianego wyżej, tematyka ta pojawia się w Wojnach religijnych czy Świadku, który nie umiat mówić. 
tekst Filipowicza jako pendant do Kartoteki, uzasadniając swoją koncepcję sposobem działania postaci zasiedlających dom narratora i techniką przenikania przez jego świadomość, a także wzajemną przyjaźnią obu literatów. Nie wnika jednak głębiej w sens opowiadania, traktując je jako kreację oniryczną o podtekście moralnym, według monografisty sny bowiem „mogą wzbudzać wyrzuty sumienia, poczucie współodpowiedzialności za innych" (Rogala 2005: 207). Niewiele jednak ma to wspólnego z sensami odpowiadania.

Wspomniana już A. Sobolewska, podkreślając proroczy kształt niektórych utworów Filipowicza (m.in. Nike), ogranicza się do zdawkowego objaśnienia: „Pisarz wyśnił [...] tłumy wynędzniałych koczowników, którzy zalewają cywilizowane miasta, paląc ogniska w salonach. «Proroctwo» Filipowicza spełniło się w latach dziewięćdziesiątych w niejednej części Europy, dotkniętej przez wojnę i regres cywilizacyjny" (Sobolewska 2000: 49).

Podążając za sugestią badaczki, można zaryzykować hipotezę, że utwór ma charakter profetyczny i że Filipowicz przewidział w nim kryzys migracyjny. Dekolonizacja, której pisarz świadkował, wywołała nasilającą się falę migracyjną z krajów byłych kolonii do industrialnych, dynamicznie rozwijających się państw europejskich: Wielkiej Brytanii, Francji, Włoch, Grecji, Portugalii. $\mathrm{O}$ ile w pierwszych dwudziestu latach po wojnie prowadzono politykę otwartości wobec migrantów, widząc w nich przede wszystkim siłę roboczą do cięższych prac, to w latach siedemdziesiątych - w związku ze wzrostem aplikacji azylanckich — zaostrzono zasady przyjmowania uchodźców. Wówczas właśnie pisał swoje opowiadanie Kornel Filipowicz. Coś (zobaczonego?, posłyszanego?) musiało pisarza skłonić do refleksji, z którą ujawnił się w onirycznym obrazie o groźnej proliferacji grupy przybyszów, domagających się najpierw litości i odrobiny strawy. Przyjęci pod gościnny dach gospodarują bez ograniczeń, z czasem stając się dla bezwolnego i zaskoczonego ich śmiałością autochtona niebezpiecznymi oprawcami. Czy mogła to być antycypacyjna myśl o procesach akulturacji w odmianie separacyjnej zmierzającej nie tylko do izolacji, ale wręcz dominacji i wypierania kultury miejscowej poprzez akty przemocy? Taki stan rzeczy uwarunkowany byłby rażącą odmiennością kulturową, wielopoziomowymi dyferencjacjami mentalnymi i nawykowymi wypływającymi z obyczajowości. Czy była to myśl spontaniczna, czy może zainspirowana drugoobiegowym przekazem o francuskich problemach z imigrantami? Tak czy owak, sen jako medium niepokoju był zabiegiem pod każdym względem bezpiecznym i asekuracyjnym, nadawał się, jako formuła paraboliczna, do realizacji zamysłu. 
Filipowicz umiejętnie i sugestywnie wprowadza czytelnika w świat marzenia sennego ${ }^{4}$. Psychofizyczny stan narratora: rozleniwienie monotonną czynnością czytania nudnawej książki, jako dopełnienia błogości „poczucia bezpieczeństwa i spokoju”, którego raczej na pewno nikt w najbliższym czasie nie zakłóci, zaokienna aura: bezwietrzne, mroźne popołudnie, tak wcześnie zimową porą stykające się ze zmierzchem, powolne opadanie płatków śniegu — czynniki te sprzyjają zapadnięciu w drzemkę, która wkrótce przeistacza się w głęboki sen. Trudno oprzeć się wrażeniu, że w tej introdukcji splata się wiele literacko-onirycznych asocjacji: jest i Karol Irzykowski ${ }^{5}$, i Bruno Schulz, i iberoamerykański realizm magiczny.

W opowiadaniu Filipowicza świat ma charakter substancjalny i jest percypowany sensorycznie, dogłębniej nawet niż na jawie, gdyż zniesiona zostaje bariera między poznającym podmiotem a poznawanym przedmiotem: „Moje zmysły wyostrzyły się, jakby nagle usunięta została przeszkoda, która oddzielała mnie od przedmiotów, kolorów, dźwięków" (Filipowicz 1982: 76), zachowana zostaje linearność i implikacyjność. Zdarzenia odbywają się w czasie i następują po sobie, wynikając z siebie lub wysnuwając się z kontekstów. W tym sensie sen ma wszelkie pozory realności i rządzi się prawami logiki. Im dalej jednak sen się rozwija, tym staje się coraz mniej mimetyczny.

Sferę metafory a zarazem fantastyki ustanawia hiperbola spotkania. Do mieszkania narratora wprowadzają się — za jego wiedzą i przyzwoleniem — przybyli z dalekich krajów biedacy. Ich gargantuiczny napływ poprzedza rozlokowanie się rodziny dwojga nędzarzy z niemowlęciem, którzy wzbudzają u empatycznego narratora litość i współczucie już prima facie — samym wyglądem. W ślad za afrykańską rodziną przestrzeń mieszkania zasiedlają inni napływający falami, a etapy ich imigracji są wyraźnie określone: od proszalności ku ekspansji. Mimo że nie jest to grupa homogeniczna w sensie etnicznym, wszyscy wyglądają podobnie, są przeraźliwie wychudzeni i poniżająco obdarci. Narrator, uświadamiając sobie, że muszą istnieć konkretne przyczyny ich upadlającego stanu, czuje się — jako prowadzący spokojne i dostatnie życie - współwinny i współodpowiedzialny „za nędzę, głód i poniewierkę, [...] wszystkie krzywdy, których doznali ci ludzie, za wszystkie pomyłki, których byli ofiarami, za wszystkie draństwa i świństwa, które im świat wyrządził” (Filipowicz: 1982: 78). Niewątpliwie akt miłosierdzia, jaki okazuje obcym, motywowany jest wpajanymi od dziecka ewangelicznymi przestrogami: „byłem głodny, a daliście mi jeść; byłem spragniony, a daliście mi

4 Filipowicz jest znawcą poetyki snu, w jego opowiadaniach, poza formą oniryczną, znajdujemy także wypowiedzi o samej strukturze marzenia sennego. W jego pisarstwie pojawia się wiele aforyzmów ze snem związanych. Przywołuje je i omawia Łojek 2000: 121-122.

5 Do Snów Marii Dunin Filipowicz nawiązuje zwłaszcza w Trzech kobietach z obozu. 
pić; byłem przybyszem, a przyjęliście mnie; byłem nagi, a przyodzialiście mnie [...] Cokolwiek uczyniliście jednemu z tych braci moich najmniejszych, mnieście uczynili” (Mt 25,40) ${ }^{6}$, apelujących do litości i wrażliwości na cudze cierpienie.

W tłumie bezdomnych, jakby z uwagi na podobieństwo ciał i losu odpersonalizowanych łachmaniarzy, jest „wysoki Murzyn o cienkiej szyi i twarzy podobnej do trupiej czaszki (gdyby istniały trupie czaszki koloru czarnego)" (Filipowicz 1982: 78), którego wyniosła postawa wskazuje na lepsze, może nawet arystokratyczne — jak podejrzewa narrator — pochodzenie. Mimo zagrożenia śmiercią z głodu i wycieńczenia, jest zbyt dumny, by o cokolwiek prosić, a nawet patrzeć w kierunku potencjalnego benefaktora. W tej postawie pod każdym względem obcego człowieka jest wyzwanie skłaniające do szacunku dla zachowanej i manifestowanej — pomimo obiektywnych warunków życia — godności. Także zachowania niektórych imigrantów (nawyki obronne powstałe w sytuacji uwięzienia) wydają się narratorowi znajome, zbliżające do tych ludzi zbieżnością doświadczeń, a przez to stwarzające więź, rodzaj wspólnoty opartej na humanitarnym „zmyśle udziału”. Narrator, niczym idealistyczny historiograf projektuje minione dzieje stojącej u jego drzwi ciżby ludzkiej; w tych domniemaniach byli oni żołnierzami, bohaterami bitew, zdobywcami orderów. Uczestniczyli w wielkich wojnach, byli onegdaj zwycięzcami, ale losy świata i koniunktura uległy zmianom, a oni stali się jeńcami, wielkimi przegranymi — toteż teraz, utraciwszy majątki, zdrowie i złudzenia, szukają tylko spokoju. Wszystkie te czynniki motywują altruistyczne decyzje narratora podejmowane bez wahania, z pełnym przekonaniem o ich słuszności i szlachetności. Jakże bowiem prawy człowiek mógłby postąpić inaczej, skoro wewnętrzny impuls współodczuwania i współcierpienia, światopogląd wsparty na miłości bliźniego i poszanowaniu inności wywołuje imperatyw niesienia pomocy?

Najpierw dokonują się transgresje specjalne. Realna przestrzeń mieszkania zmienia się w przytulisko dla coraz liczniej i gęściej zaludniających je imigrantów, którzy gospodarują w nim jak chcą i robią co chcą. Miejsce dawniej zorganizowane tak, by służyło jednemu człowiekowi, nagle przeobraża się w obóz

\footnotetext{
${ }^{6}$ Przekaz nowotestamentowy zgadza się w kwestii okazywania bliźniemu miłosierdzia z imperatywami Starego Testamentu. Objawia się m.in. w księgach: „Ja nakazuję: Otwórz szczodrze dłoń bratu uciśnionemu lub ubogiemu na twej ziemi” (Pwt 15,11), „Nie odpychaj proszącego w ucisku, a od ubogiego nie odwracaj oblicza” (Syr 4,1.4). „Pożycza Panu, kto lituje się nad biednym, za dobrodziejstwo On mu wynagrodzi” (Prz 19,17). „Błogosławiony, czyje oko jest miłosierne; bo chlebem podzielił się z potrzebującym” (Prz 22,9). „Dzielić swój chleb z głodnym, do domu wprowadzić biednych tułaczy, nagiego, którego ujrzysz, przyodziać i nie odwrócić się od współziomków. Wtedy twoje światło wzejdzie jak zorza i szybko rozkwitnie twe zdrowie. Sprawiedliwość twoja poprzedzać cię będzie, chwała Pańska iść będzie za tobą” (Iz 58,7-8) „Szczęśliwy ten, kto myśli o biednym i o nędzarzu" (Ps 40,2).
} 
dla uchodźców. Ład i funkcjonalność przekształcają się w chaos wyznaczony odmiennością kultury. Wszystkie pomieszczenia zapełniają się życiem, nieużywane dotychczas przedmioty zyskują nowe zastosowania. Metamorfoza przebiega nieustannie i czyni z oswojonego, bezpiecznego dotąd domu najpierw przestrzeń zawłaszczoną przez obcych, którzy przenoszą w jej obręb własne zwyczaje i formy zachowań, aby w końcu zmienić ten dom w ponury krajobraz dewastacji.

W marzeniu sennym znikają bariery języka; mówiący narzeczami dalekich krajów przybysze są przez narratora rozumiani tak, jak gdyby władał on ich językiem. Rozmowy czy raczej porcje informacji nie wykraczają poza rudymentarną komunikację dotyczącą kwestii prozaicznych: jedzenia, spania, higieny codziennej. Zauważyć jednak należy, że interaktywność narratora w zasadzie od samego początku także jest ograniczona (akinezja może wynikać — rzecz jasna - z nieruchomości ciała podczas śnienia w fazie REM). Zastrzega się, że ludzie ci nie brzydzą go („nie wydawali mi się odrażający, woń, którą wydzielali, przypominała zapach sierści starych zwierząt, spróchniałego drewna, zbutwiałych szmat" - Filipowicz 1982: 80), nie wzbudzają wstrętu. Wydaje się więc, że zasadniczym tego powodem jest jego nieekspansywna osobowość i dyskrecja. Zaprasza do siebie przybyszów, ale separuje się od nich, wycofuje do pozycji lokatora, do „swojego” pokoju, aby dalej zagłębiać się w ową nudnawą lekturę. Nie martwi się o oddaną w użytkowanie przestrzeń własną, nie dba o swój dobytek, nawet nie przyjmuje stanowiska obserwatora, nie kontroluje procesu „rozgaszczania się" zaproszonych do wnętrza ludzi. W tym zaufaniu do ich samoobsługi i korzystania z gościny bez ograniczeń jest jakaś dziwna naiwność, przekonanie o partnerstwie, założenie o uczciwości (mierzonej własną miara). Jest to tolerancja bez granic ${ }^{7}$. Cena tej bezwarunkowej poprawności będzie słona.

Przybysze nie nawiązują bowiem kontaktu, z okazyjnej sytuacji korzystają bez skrępowania, nie namyślają się nad przyczynami dobroczynności, sądzą zapewne, że ktoś odstępując im swoje terytorium, miał w tym jakiś cel, zapewne nadmiar, zbytek, słowem - nie dokonują zbytecznych refleksji nad intencjami. Traktują oddane sobie lokum jako miejsce pozyskane, jako podbój, kolonię. Nie są zainteresowani dialogiem z osobą, która ich zaprosiła. Niewykazujący cienia wdzięczności, milcząco tolerancyjni dla gospodarza, stopniowo zaczynają go wypierać:

Nie robili mi nic złego, po prostu spychali mnie, musiałem krok po kroku ustępować, cofać się, aż znalazłem się w moim pokoju. Usiadłem na krześle. Widziałem i słyszałem, jak ludzie krążyli koło mnie i rozchodzili się po pokojach. Ocierali się o mnie, ale nie patrzyli na mnie, jakby mnie w ogóle nie widzieli, jakbym nie istniał. Zajęci byli

7 Pisał o tym Stefan Melkowski (1984: 298) w związku ze zbiorem opowiadań Gdy przychodzi silniejszy. 
urządzaniem się w moim mieszkaniu i radzili sobie z tym zupełnie dobrze. [...] ich pierwszą czynnością w moim pokoju było rozniecenie ogniska, nad którym powiesili osmalony kocioł. Wcale mnie to nie zdziwiło, tak przecież postępują wszyscy wędrowcy na całym świecie, gdy tylko znajdą wodę i spokojne miejsce na biwak. Opału nie musieli daleko szukać, w moim mieszkaniu było go pod dostatkiem, ale zauważyłem, że nie ruszali moich książek i nie zdejmowali obrazów ze ścian. Mój cichy dotąd i pusty dom napełniał się życiem [...] ściągnięto z podłóg dywany, znikły ze ścian kilimy. Służyły teraz jako posłania i zasłony, co mnie także nie dziwiło. Dywany i kilimy spełniały u mnie tylko rolę dekoracji, teraz przywrócono im dawne, prawdziwe funkcje. Przypuszczam, że moi lokatorzy podobnie postępowali także z wieloma innymi przedmiotami w moim mieszkaniu. (Filipowicz 1982: 80-81)

Palenie ogniska „w salonie” i wykorzystywanie na opał przedmiotów do tego nieprzeznaczonych jest oczywiście możliwe we śnie, jak wiele innych niedorzecznych czynności. Niewidzialność śniącego, jak również jego absolutna wyrozumiałość i kwietyzm także dadzą się usprawiedliwić, a nawet w sensie psychologicznym uzasadnić — sennym marzeniem. Jeśli jednak potraktować sen jako parabolę, odsłoni się przed czytelnikiem niepokojąca sytuacja akulturacji. Zazwyczaj bowiem kulturą dominująca jest ta, która przyjmuje, a recesywną ta, która napływa. Tymczasem w opowiadaniu Kornela Filipowicza jest dokładnie odwrotnie: bierność i przyzwolenie gospodarza, jego dyskretność i kultura osobista powodują spychanie go i eliminację, której nie tylko się poddaje, ale swoją postawą warunkuje. Brak reakcji na zachowania nieadekwatne do miejsca, tolerancja i wielkoduszność zdradzają objawy zupełnej inercji i zaskakującej refleksji, będącej kwintesencją apatii: „Pomyślałem, że widocznie mój dom przeznaczony został przez kogoś na rozbiórkę" (Filipowicz 1982: 82). W tym aspekcie żadnym pocieszeniem nie jest oszczędzanie kultury miejscowej („zauważyłem, że nie ruszali moich książek i nie zdejmowali obrazów ze ścian"), ta bowiem — jako duchowa — nie zajmuje imigrantów mających na względzie wyłącznie stronę materialną.

Tej bezwolności i martwoty myślowej narratora zaczynają towarzyszyć metamorfozy w jego wyglądzie: raptownie zaczyna starzeć się jego ciało, a także ubranie, które ma na sobie. Ofiarność pogłębia się i aktywuje geny starości w procesie „samobójstwa altruistycznego”, ku któremu skłania nadmiar empatii, nadmiar socjalizacji ${ }^{8}$. Dopiero te symptomy zmierzających do unicestwienia zmian bezpośrednio ingerujących w somatyczność narratora, wywołają w końcu jego reakcję: „nie byłem zdecydowany, co zrobię, ale wiedziałem, że muszę się zdobyć na jakieś działanie, ruch, przenieść się na inne miejsce” (Filipowicz 1982: 82). A zatem

${ }^{8}$ Filipowicz — jako biolog — orientował się niewątpliwie w podobnych teoriach. Ten, na pozór niejasny, fragment tekstu jest ilustracją wspomnianego procesu opisanego m.in. przez francuskiego socjologa Emila Durkheima w jego książce Samobójstwo (1897). 
wpływ otoczenia sprowadza destrukcję, jego szkodliwość przyspiesza naturalne procesy starzenia. Gdy narrator uświadamia sobie źródło emanacji zła i zguby, i gdy zapragnie uwolnić się, wstać i wyjść, okazuje się, że jest to niemożliwe, bowiem chcąc nie chcąc stał się niewolnikiem swoich gości, którzy uciekają się wobec niego do przemocy i użycia siły. Bezpieczne dotąd wnętrze (bo cóż jest bezpieczniejszego aniżeli własny dom?) zmienia się w więzienie. Koegzystencja z tymi ludźmi staje się udręką. Obojętność (ani sympatia, ani nienawiść) i zimna konsekwencja dozorowania prowokuje konstatację:

Jak to się stało, że ci biedni, wynędzniali, prześladowani ludzie sami przeistoczyli się nagle w prześladowców i dlaczego ja właśnie miałem być ich ofiarą? Akurat ja, który wpuściłem ich do swojego mieszkania, ja, który nigdy nie byłem ich wrogiem, który zawsze byłem ich sprzymierzeńcem i obrońcą, który oddawałem im moje najlepsze myśli, uczucia, czyny? (Filipowicz 1982: 83)

Narrator nie wykazuje jednak emocji, jedyną ekspresją, jaką rodzi bezgraniczne zdumienie niesprawiedliwością jest, bezowocna niestety, próba werbalnego porozumienia. Obcy kontrolują wszystko. Trzymają wartę, mającą nie dopuścić nie tylko do tego, by narrator odszedł, ale także by nie zasnął, by znalazł bezpieczny azyl snu, jak zwierzę, „któremu wydaje się, że gdzie jak gdzie, ale we śnie nic złego mu nie grozi”" (Filipowicz 1982: 75). Więc potrząsają nim i trzeźwią, ilekroć mruży powieki, ilekroć jego twarz zapada się w sobie i osiąga bezruch zwiastujący nadchodzącą senność. Z czasem strażnicy stają się coraz bardziej brutalni. Deprywacja snu, szczególny rodzaj tortur, powoduje odczucia przykre, a nawet bolesne: „czułem się jak stary człowiek, który w sposób naturalny umiera i umrzeć musi, a nawet chce, ale ktoś ciągle na siłę zawraca go z drogi i zmusza do życia, do którego nie ma już sił ani ochoty" (Filipowicz 1982: 85-86). Niemożność uwolnienia się narratora z opresji, której został poddany we własnym domu i na własnym krześle, staje się nie do zniesienia. Absurdalny klincz skłania narratora do ważnych pytań i spekulacji:

Dlaczego? Czy miał to być jakiś rodzaj tortury? Może chcieli jeszcze coś na mnie wymusić? Pieniądze? Kosztowności, których nie miałem? Moje myśli wracały uporczywie do pytania, jak to się mogło stać, że moje ludzkie uczucia, dobre chęci, szlachetne odruchy - obróciły się przeciwko mnie? Jak mogło dojść do tego, że będąc sojusznikiem ludzi biednych i pokrzywdzonych — stałem się ich ofiarą, więźniem, a może, w jakimś nieznanym celu, nawet zakładnikiem? Padłem ofiarą straszliwej pomyłki, czy byłem przedmiotem z góry ukartowanej perfidnej gry, którą prowadził ktoś, kto miał nie tylko wobec mnie, ale i tych nieszczęśliwych ludzi — jednakowo złe zamiary? A może to nie miało nic wspólnego $\mathrm{z}$ dobrem i złem, bogactwem i nędzą, i aby to pojąć, wystarczyło tylko być człowiekiem głęboko wierzącym? (Filipowicz 1982: 84) 
Przywołany passus jest w opowiadaniu Filipowicza istotny. Narratorowi trudno pojąć, że w zamian za spontanicznie i bezinteresownie okazaną życzliwość, spotkała go niezasłużona kara: został postawiony w stan zastraszenia i wymuszenia. Mnożąc pytania, próbuje implikacyjnie tłumaczyć sobie niezrozumiały dla siebie stan rzeczy. Nie potrafi jednak znaleźć winnego, choć w domniemaniach, jakie snuje, wiele jest interesujących spostrzeżeń. Nie powinien przecież dziwić ani brak wdzięczności, ani z góry ukartowana gra, takie bowiem praktyki wynikają z różnic mentalnych, z koniunktury, z gier politycznych, z siły pieniądza etc. Gdy logika zawodzi, narrator próbuje szukać przyczyn w metafizyce, tu bowiem zawsze znajdzie się odpowiedź; w Biblii wiele jest takich ustępów, które wskazują na pozalogiczne prawa, jakimi rządzi się świat: „Kiedy [...] dajesz jałmużnę, niech nie wie lewa twoja ręka, co czyni prawa, aby twoja jałmużna pozostała w ukryciu. A Ojciec twój, który widzi w ukryciu, odda tobie” (Mt 6, 2-4) albo „[...] czyńcie dobrze i pożyczajcie, niczego się za to nie spodziewając. A wasza nagroda będzie wielka i będziecie synami Najwyższego" (Łk 6,35). Aby jednak uznać te prawa za własne, trzeba — jak twierdzi narrator — „być człowiekiem głęboko wierzącym”, to znaczy nie zadawać żadnych pytań i godzić się ze wszystkim, zakładając, że gdzieś ktoś układa scenariusz, na który nie mamy wpływu i że z pewnością zrealizuje się on do końca i na naszą korzyść, ale nie wiadomo kiedy. Człowiekowi, który buduje wiedzę o świecie poprzez to, „co widzi i wie”, a zatem konstruuje wedle rozumu i doświadczenia, potrzebna jest konkretyzacja i wyjaśnienie oparte na racjonalizacji, a nie metafizyce. Jaka więc jest odpowiedź na pytania narratora? $\mathrm{Z}$ pewnością zbieżna $\mathrm{z}$ poglądami Filipowicza na historię, w której jednostka jest nie tylko jej uczestnikiem, ale i ofiarą - bez winy (Stabro 2000: 273).

Postawa narratora, niezmiennie statyczna, stoicka, introwertycznie zanurzona w myślowym dylemacie, z którym przyszło mu się zmóc, nie ma jednak za wiele wspólnego ze statusem ofiary, która chce uwolnić się za wszelką cenę, o obronie swego terytorium i wyparciu ekspansywnych intruzów nie wspominając, ułuda humanitaryzmu uśpiła w nim naturalne metody obrony, a ufność spowodowała przeoczenie symptomów destabilizacji. Pole jego działań — ograniczających się do medytacji wewnętrznych - wyznacza bezruch totalny sygnujący wrzenie myśli. Wskutek maksymalnej koncentracji udaje mu się zmylić czujność wartowników i w ułamku sekundy, która umyka prześladowcom, uciec w sen, czyli... przebudzenie, uwolnienie z pułapki koszmaru, w którym niewidzialne nici łączą ze sobą oprawców i ofiary. Wtedy wszystko znika, a dookolnemu światu — ku uldze narratora - zostaje przywrócony ład i dotychczas wyznaczająca go równowaga; następuje tak często powtarzający się w pisarstwie Filipowicza powrót 
do rzeczywistości bezpiecznego, nienaruszonego domu, przestrzeni o cechach trwałości i stabilności, do wolności rozumianej jako błogosławiona samotność (Feliksiak 2014: 335-338).

Ekwiwalentyzacja snu i jawy nie jest prostym zabiegiem odwrócenia, ale ma określony cel - ma sugerować prawdziwość, a nie iluzoryczność zdarzenia: „[sen] wydawał mi się jeszcze bardziej rzeczywistą jawą niż ta, na której żyłem dotąd" (s. 75). Obcy nie pozwalają narratorowi zasnąć, byłoby to bowiem równoznaczne z ich anihilacją. Przytomność narratora jest jego torturą a zarazem ich statusem ontycznym: „Gdybym zasnął - przestaliby istnieć! Może nie tak zupełnie, w każdym razie musieliby stąd odejść, poszukać sobie innego miejsca albo wrócić do swoich krajów, do niesprawiedliwości, nędzy, głodu, chorób. Ale oni nie chcieli wracać do swoich krajów, bo wiedzieli, że nie czeka ich tam nic dobrego" (Filipowicz 1982: 84-85).

Antycypacyjny sen Filipowicza można rozumieć jako przestrogę przed... snem, rozumianym jako uśpienie, bezwolność. We śnie grozić nam może jednak — wbrew „naiwnej ufności zwierzęcia” — niebezpieczeństwo. „Cóż bowiem złego może się nam przydarzyć pod naszą nieobecność?” — dyskretnie ironizuje pisarz, zadając retoryczne pytanie. Jedynie obecność gwarantuje bezpieczeństwo; a więc: świadomość istnienia, uznanie swojej podmiotowości, zdolność do interakcji, ale także rozsądek i rozwaga, czujność, dystans. Tylko obecność gwarantuje porozumienie z Innym. Zaufanie, tolerancja, przyznanie prawa do wolności i samostanowienia muszą iść bowiem w parze z szacunkiem dla swojego terytorium, swojej tradycji, swojej kultury.

W przewidywaniu powikłanych problemów migracyjnych na wiele lat przed ich urzeczywistnieniem Kornel Filipowicz nie pozostaje odosobniony. Niemal w tym samym czasie Jean Raspail pisze słynny Obóz świętych, powieść o inwazji hinduskich nędzarzy na wybrzeża Francji, szukających tu swojej „ziemi obiecanej”. Bezprecedensowość i skala zjawiska obnażają zakłamanie i słabość zachodniego świata, pozbawionego nie tylko trwałych wartości, ale wręcz elementarnej zdolności samozachowawczej. Oba teksty wykazują podobieństwa, w obu ujawnia się wizja kolonizowania człowieka Zachodu przez litość i — co podwójnie paradoksalne - odwołanie się do miłosierdzia, wywiedzionego z zasad chrześcijańskich a zarazem poglądów lewicowych. Dalszym ciągiem literackich zmagań z trudnym problem migracji i zarazem akulturacji będzie Ulegtość Michaela Houellebecqa z roku 2015, powieść diagnozująca społeczeństwo francuskie jako bierne i wyzute z wszelkich etycznych dogmatów; w zamian za obietnice wielożeństwa intelektualiści stają się prozelitami, decyzje swoje argumentując pseudonaukowym bełkotem. Recesja edukacji zapewni im błogie lenistwo, za to 
zaspokoi najprymitywniejsze zachcianki, powrót do poligamii i odczłowieczonej pierwotności ${ }^{9}$ w myśl zasady Heureux ceux que satisfait la vie, ceux qui s'amusent, ceux qui sont contents ${ }^{10}$.

\section{BIBLIOGRAFIA (WYBÓR)}

Balbus Stanisław. 1999. Kornel Filipowicz — szkic do portretu i próba zbliżenia. W: Literatura wspótczesna. T. 2. Red. Ryszard Nycz. Kraków: Universitas. S. 247-270.

Feliksiak Elżbieta. 2014. Antropologia literatury. Interpretacje i studia. Kraków: Universitas. Chaos i tad w krajobrazie Kornela Filipowicza. S. 334-349.

Filipowicz Kornel. 1959. Po burzy. Warszawa: Czytelnik.

Filipowicz Kornel. 1980. Między snem a snem. Kraków: Wydawnictwo Literackie.

Filipowicz Kornel. 1982. Koncert f-moll $i$ inne opowiadania. Kraków: Wydawnictwo Literackie.

Filipowicz Kornel. 1989. Rozmowy na schodach. Kraków: Wydawnictwo Literackie.

Lipowski Wojciech. 2005. „Zrozumieć i nazwać wszystko”. Niezwykta codzienność w opowiadaniach Kornela Filipowicza. „Ruch Literacki” 2005, z. 4-5. S. 453-474.

Łojek Mieczysław. 2000. Prawdy powszechne jako inkrustacje matych form narracyjnych. W: Kornel Filipowicz. Szkice do portretu. Red. Stanisław Burkot, Jerzy S. Ossowski, Jacek Rozmus. Kraków: Wydawnictwo Literackie. S. 114-121.

Melkowski Stefan. 1984. Domena prozy. Warszawa: Ludowa Spółdzielnia Wydawnicza.

Ossowski Jerzy S. 2000. Klucze do matych form Kornela Filipowicza. W: Kornel Filipowicz. Szkice do portretu. Red. Stanisław Burkot, Jerzy S. Ossowski, Jacek Rozmus. Kraków: Wydawnictwo Literackie. S. 228-247.

Pieszczachowicz Jan. 2010. Ku wielkiej opowieści. O życiu i twórczości Kornela Filipowicza. Kraków: Wydawnictwo Literackie.

Pismo Święte Starego i Nowego Testamentu (różne wydania).

Rogala Stanisław. 2005. Twórczość literacka Kornela Filipowicza. Kielce: Wydawnictwo Akademii Świętokrzyskiej.

Sobolewska Anna. 2000. „... przecież życie się nie kończy”. Kornela Filipowicza proza doświadczeń wewnętrznych. W: Tematy i pryzmaty. Studia o prozie polskiej XX wieku. Red. Alina Brodzka, Zygmunt Ziątek. Wrocław: Zakład Narodowy im. Ossolińskich. S. $45-58$.

9 D. Samborska-Kukuć, „Nie hukiem, ale skomleniem”- bankructwo wartości cztowieka Zachodu w „Ulegtości” Michela Houellebecqa (w druku).

${ }^{10}$ Błogosławieni ci, którym życie przynosi satysfakcję, którzy się bawią, którzy są zadowoleni (introdukcja recenzji Guy de Maupassanta poświęconej powieści A rebours Karla-Jorisa Huysmansa; była opublikowana w czasopiśmie „Gil Blas” 1884, z dnia 10 czerwca). 
Stabro Stanisław. 2002. Natura, wojna, epika. O pisarstwie Kornela Filipowicza. W: Od Emila Zegadtowicza do Andrzeja Bobkowskiego. O polskiej prozie XX wieku. Kraków: Universitas. S. 262-274.

\section{Dorota Samborska-Kukuć}

\section{THE ONEIRIC ANTICIPATION OF KORNEL FILIPOWICZ}

\section{(summary)}

Kornel Filipowicz's short writing forms are frequently oneiric in nature; factual accounts of dreams. An example is a short story written toward the end of the 1970s titled Gdy przychodzą we śnie ("When in dream they come"). It is a prophetic vision of a peculiar meeting, whereby the sympathising and merciful narrator invites a group of Afro-Asian refugees to his abode. The visitors promptly proliferate, eventually ruining the hospitable home and taking the host captive.

The short description of a nightmare contains transparent anticipative visions of the contemporary migration crisis currently plaguing Western Europe, together with positing acculturation as the main concern of multicultural societies. Of particular note is the author's idea of colonising Western man through Christian-based sympathy and tolerance, which not only breeds gratitude, but also turn against the benefactors.

KEYWORDS

Filipowicz Kornel; onirism; acculturation 
Prace Polonistyczne, seria LXXII, 2017

ISSN: 0079-4791; e-ISSN: 2450-9353

DOI: $10.26485 / \mathrm{PP} / 2017 / 72 / 5$

Matgorzata Domagalska

\section{ZBRODNIA W WIELOETNICZNYM LWOWIE. ŻYDZI W KRYMINAŁACH MARKA KRAJEWSKIEGO}

\section{SŁOWA KLUCZOWE}

Marek Krajewski; powieść kryminalna; Lwów; relacje polsko-żydowskie; mit mordu rytualnego

Według danych spisu powszechnego z 1931 roku wśród trzydziestu dwóch milionów obywateli II Rzeczpospolitej przeważali Polacy (Zieliński 1985: 124-126). Stanowili niemalże siedemdziesiąt procent obywateli, ale kraj zamieszkiwali także Ukraińcy, Żydzi, Białorusini oraz Niemcy. Żydzi dominowali wśród ludności miejskiej, a ich czwarta część z niemal trzymilionowej populacji mieszkała w pięciu miastach: Warszawie, Łodzi, Wilnie, Krakowie i Lwowie ${ }^{1}$. Nic więc dziwnego, że autorzy kryminałów retro uwzględniają w swoich utworach specyfikę demograficzną ówczesnej Rzeczpospolitej i przydają role bohaterom żydowskim w powieściowych wątkach ${ }^{2}$. Choć fenomen kryminału retro doczekał się już obszernych studiów, figura Żyda czy żydowskie klisze nieczęsto były przedmiotem badawczych dywagacji. Wybrane utwory pod tym kątem analizowały:

Małgorzata Domagalska — dr hab., Zakład Literatury Pozytywizmu i Młodej Polski, Instytut Filologii Polskiej i Logopedii, Wydział Filologiczny, Uniwersytet Łódzki, ul. Pomorska 131/133, 90-236 Łódź; e-mail: maldomag@wp.pl

1 Według danych podawanych przez Jerzego Tomaszewskiego (Tomaszewski 1993: 162) Żydzi w Warszawie w 1931 roku stanowili 30,1\%, Łodzi (33,5\%), Wilnie (28,2\%), Krakowie (25,8\%) i Lwowie $(31,9 \%)$.

2 Np. Marek Krajewski, Paweł Jaszczuk — Lwów, Konrad Lewandowski — Łódź, Marcin Wroński - Lublin, Małgorzata i Michał Kuźmińscy — Kraków, Krzysztof Beśka, Aleksander Błażejowski - Warszawa. 
Maria Antosik-Piela (2011: 108-110) i Martyna Steckiewicz (2014: 109-214), a studium, ale w odniesieniu do powieści kryminalnej o tematyce współczesnej, opublikował Robert Więckowski (2015: 66-76).

Zarówno w kryminałach, których akcja osadzona jest w dwudziestoleciu, jak i bliżej współczesności relacje Polaków i Żydów nie znajdują się w centrum fabuły. Jednak kryminały z wątkiem żydowskim w tle mierzą się „, częścią stereotypów, legend i przemilczeń, jakimi w społecznym odbiorze przesiąknięta jest historia relacji polsko-żydowskich" (Więckowski 2015: 67). Ich twórcy, kreując przedwojenną rzeczywistość, korzystają nie tylko z wiedzy wyniesionej z bibliotecznych kwerend i licznych lektur, opierają się także na obecnych w społecznej świadomości wyobrażeniach czy stereotypach. Warto więc zbadać, do jakiego typu wyobrażeń się odwołują, co wykorzystują w swoich fabułach i jakie skojarzenia uruchamiają. Przedmiotem moich rozważań będą reprezentacje żydowskiego życia w powieściach Marka Krajewskiego z cyklu o komisarzu Popielskim, których akcja rozgrywa się w przedwojennym Lwowie. Poprzedzające je tomy osadzone w przestrzeni Breslau poddane zostały już refleksji. Krytycy i badacze wskazywali literackie prototypy postaci śledczego - Eberharda Mocka (Dobek 2008: 14-15), przyglądali się miastu, w którego labiryncie dokonywane są zbrodnie (Ostaszewski 2008: 19; Kosmala 2011: 225), dywagowali nad typologią gatunku (Krupa 2008: 243-163; Dobek 2008: 13; Ostaszewski 2008: 20). Rekapitulacji wcześniejszych ustaleń w tym zakresie dokonał Wojciech Browarny (Browarny 2010: 245-258) ${ }^{3}$.

Pierwszy i drugi cykl powieści Krajewskiego łączą podobieństwa - rekonstrukcja nieistniejących już światów, „fizjologiczny opis miasta”, drastyczne zbrodnie i zwyrodniali w swym wyrafinowaniu mordercy oraz śledczy, wykorzystujący $\mathrm{w}$ swoich dochodzeniach metody niekoniecznie zgodne z prawem (Kosmala 2011: 231, 238; Medecka 2013: 26-29). W inicjalnej części nowej serii komisarz Edward Popielski ma rozwikłać tajemnicę morderstwa młodych kobiet. Trop prowadzi z Wrocławia do Lwowa, stąd też do tego miasta zostaje oddelegowany komisarz Eberhard Mock ${ }^{4}$. Choć obaj detektywi na początku

3 Browarny uwzględnił podział powieści kryminalnej na detektywistyczną i kryminalno-sensacyjną, dokonany przez Stanisława Barańczaka, jednak za Helmutem Heissenbuttelem uznał go za niewystarczający. Podkreślił, że „czarny kryminał wyrasta z detective story, zachowując jej schemat podstawowy, a równocześnie zbliża się do innych odmian gatunkowych powieści. Tropem jednego z tych zbliżeń można dotrzeć do powieści realistycznej” (Browarny 2010: 248). Sam Marek Krajewski wielokrotnie wskazywał na inspiracje płynące z chandlerowskiego kryminału (Borowczyk, Larek 2009: 93; Brylla 2016: 225).

4 Komisarz Eberhard Mock jest bohaterem cyklu powieści zapoczątkowanym przez Śmierć w Breslau (Wrocław 1999) a zakończonych powrotem do młodości protagonisty w tomie Mock (Kraków 2016). 
nie przepadają za sobą, wkrótce połączy ich pasja, namiętność do sprzedajnych kobiet oraz zamiłowanie do mocnych trunków (Zimna 2009: 102). Ich losy splotą się wielokrotnie, a tragiczne doświadczenia życiowe i historyczne (wszak obaj staną się ofiarami historii) zbudują ich wzajemne poczucie lojalności, oparte na prawdziwej przyjaźni.

W inicjującej cykl Gtowie Minotaura patrzymy na przedwojenny Lwów okiem komisarza z Niemiec. Przybywający do miasta Mock ogląda miasto niczym Alfred Döblin w cyklu swoich reportaży Podróż po Polsce ${ }^{5}$. Tak jak Döblin z Berlina, również Mock podróżuje z Brelsau do Lwowa pociagiem, podobne są także jego pierwsze wrażenia. W relacji narratora:

Jego uwagę na stacjach przykuwali przede wszystkim Żydzi, którzy — rozpoznawalni po charakterystycznych chałatach, okrągłych czapkach z daszkiem i długich brodach niczym nie przypominali Żydów z Breslau, odróżniających się od swoich niemieckich współobywateli jedynie pewnymi cechami antropologicznymi. Tutaj w Polsce, odznaczali się oni również innym strojem i językiem. Mock wiedział, że używają jakiegoś średniowiecznego dialektu niemieckiego, ale nigdy wcześniej go nie słyszał. Toteż z wielką ciekawością przysłuchiwał się handlarzom żydowskim na peronach. Ich kłótnie i dyskusje były dla Mocka widomym znakiem, że znalazł się w jakimś kraju przejściowym, na pograniczu Europy i Wschodu, gdzie osobliwi ludzie językiem swym należą do Zachodu, zaś gestykulacja i ekspresja sytuują ich raczej na jakiś targowiskach Orientu. (Krajewski 2009: 96)

Cytat to ciekawy, ujawniający zdziwienie i ignorancję komisarza, obcującego dotychczas zapewne z Żydami, którzy poza wyznaniem nie różnili się kulturowo od współobywateli Niemców. Jego rodzinne miasto było wszak w przeszłości obok Berlina i Królewca jednym z trzech głównych centrów haskali w Prusach. Akulturacji sprzyjał tam rozwój szkolnictwa, zapoczątkowanego w 1791 roku powstaniem słynnej Szkoły Wilhelma dla chłopców. Dalsze bariery znosił edykt emancypacyjny z 1812 roku, choć trudności w dostępie do administracyjnych stanowisk istniały jeszcze długo, by powrócić ponownie po dojściu nazistów do władzy. Także obecność Żydów ze Wschodu tak zwanych Ostjuden w społecz-

5 Pierwsze zderzenie Döblina z ortodoksyjnym światem żydowskim ma miejsce w Warszawie. Autor Podróży po Polsce pisze:

„Stoję na przystanku tramwajowym, studiuję bardzo uprzejme tablice [...]. Nagle w thumie nadchodzi z przeciwka samotny mężczyzna z brodatą twarzą, w czarnym obszarpanym chałacie: na głowie ma czarną czapkę z daszkiem, na nogach wysokie buty z cholewami. Tuż za nim, głośno rozprawiając, w języku, w którym rozpoznaję niemiecki, jeszcze jeden w czarnym chałacie, rosły, z szeroką czerwoną twarzą, z rudym puchem na policzkach i nad wargą. [...] Spada to na mnie jak cios. Znikają w tłumie. Nikt na nich nie zwraca uwagi. To Żydzi. Jestem zdumiony, nie — przerażony" (Döblin 2000: 14). 
ności żydowskiej Wrocławia była minimalna, a tradycyjne formy religijności zanikały w procesie sekularyzacji (Ziątkowski 2000: 44, 83).

Komisarz Mock zatem nieczęsto, o ile w ogóle, mógł na ulicach swego miasta zobaczyć tradycyjnych Żydów i usłyszeć jidysz. Włożone w myśli Mocka spostrzeżenia na temat języka wschodnioeuropejskich Żydów powielają potoczne przekonanie budowane na podobieństwie języka niemieckiego i jidysz, natomiast nie odzwierciedlają rzeczywistych przekonań istniejących wtedy w Niemczech ${ }^{6}$. Mock przypisuje jidysz przynależność do Zachodu ze względu na podobieństwo do niemczyzny, ale właśnie ta cecha u antysemicko nastawionych Niemców była powodem odrazy. Jidysz był przez nich postrzegany jako zniekształcony, zdegenerowany język niemiecki właściwy dla Żydów i odzwierciedlający ich naturę (patrz Gilman 1990: 68-86). Także wśród liberalnych niemieckich Żydów nie cieszył się on sympatią, albowiem w myśl postulatów żydowskiego oświecenia, oprócz hebrajskiego jako języka kultu religijnego i nowoczesnej kultury żydowskiej, codziennej komunikacji powinna służyć tak zwana mowa krajowa?

Również dzielnica żydowska jawi się komisarzowi w sposób, który określa mianem orientu. W tym przypadku Mock umiejscawia Ostjuden właśnie w obrębie Wschodu, przeciwstawianego racjonalnej i uporządkowanej kulturze Zachodu, w którym nurt haskali niwelował różnice kulturowe ${ }^{8}$. Orient w tradycji literackiej i kulturowej w deskrypcji polskich Żydów wartościowany był pozytywnie, a orientalizacja wprowadzała pożądany element egzotyki (Prokop-Janiec 2005: 91-108). Być może taki opis ma także podkreślić brak uprzedzeń rasowych Mocka, wszak przybywa on z kraju, w którym od 1935 roku obowiązują ustawy rasowe.

Eberhard Mock przecierał oczy ze zdumienia. Czegoś takiego jeszcze nigdy nie widział. Gdyby nie śniegi i mróz, byłby pewien, że oto znalazł się na jakimś tureckim albo arabskim targu. Brodaci Żydzi zionący wonią czosnku, zamykali swe stragany i podtykali mu pod nos rozmaite przedmioty. [...] I oto przed oczami Mocka rozpostarła się prawdziwa panorama tandety [...] (Krajewski 2009: 167)

${ }^{6}$ Na temat genealogii języka jidysz i jego podobieństwa do języków grupy zachodniogermańskiej patrz Geller 1994: 34-55.

Jak zauważa Marcin Wodziński wśród argumentów wysuwanych przez zwolenników modernizacji na rzecz porzucenia jidysz, były: postrzeganie tego języka jako bariery w integracji społecznej, przypisywanie mu funkcji „mowy sekretnej” wzmacniającej tendencje separatystyczne i realizującej standardy podwójnej moralności oraz w aspekcie estetycznym — jidysz uznawano za brzydki i anachroniczny, za zepsuty żargon niemiecko-żydowski (Wodziński 2008: 254).

8 Podobnie zresztą na Ostjuden patrzyli liberalni Żydzi z Zachodu. Często dokonywali oni samoidentyfikacji nie wobec Niemców, ale wobec stworzonego symbolicznego konstruktu zacofanych, anachronicznych „braci ze Wschodu”. Patrz szerzej Ascheim 1982. 
Nic dziwnego, że oko Mocka w poszukiwaniu różnicy spogląda na niemieckich, zasymilowanych Żydów antropologicznie. To duże nosy i uszy mają świadczyć o żydowskości. Takie postrzeganie Żydów przez pryzmat cielesności ma jednak swoją niechlubną tradycję. Zdaniem Sandera Gilmana, autora fundamentalnej pracy Jew's body, w opisie żydowskich postaci to najczęściej nos i usta są znakiem wrodzonej i niezbywalnej różnicy (Gilman 1991: 180). Jednak narrator uznaje za słuszne podkreślić, że Mock rasistą nie był, gdyż, jak informuje:

W roku 1934 odszedł z policji do abwery. Nie mógł patrzeć, jak kanalie gestapowskie wnikają jak krętki blade w jego świat i przewracają wszystko do góry nogami. Nie mógł spojrzeć w oczy dwóm swoim najlepszym ludziom, którzy tylko dlatego musieli pozostawić za sobą całe życie zawodowe, bo byli Żydami. Odszedł wierząc, że w abwerze nie oblepi go ten cały brud, który wypłynął na powierzchnię po wyborach do Reichstagu i „nocy długich noży”. I nagle, po trzech latach, w pierwszy dzień nowego roku ten szlam go dopadł. (Krajewski 2009: 28)

W drugiej części serii, w Eryniach, tradycyjni Żydzi pojawiają się w różnych przestrzeniach miejskiego krajobrazu. Już początek powieści wprowadza klimat lwowskiej ulicy, eksponując zróżnicowanie etnicznych mieszkańców Lwowa ${ }^{10}$. Scena w miejskim komisariacie ujawnia napięcia pomiędzy wezwanym na przesłuchanie Rusinem a Żydem, wygrażających sobie wzajemnie w stylizowanym języku' ${ }^{11}$.

Oprócz tradycyjnych Żydów, parających się handlem, Krajewski wprowadza również żydowską spolonizowaną inteligencję ${ }^{12}$. Przedstawiciele wolnych

9 Choć wcześniej Mock nie jest wolny od antysemickiej przemocy (Śmierć w mieście Breslau), Krajewski w Festung Breslau daje mu jednak szansę dostrzeżenia jego błędów i win (Szybowicz, Warkocki: 72).

${ }^{10}$ „Nad lwowskim starym rynkiem wstawał świt. Różowy blask wdzierał się pomiędzy nędzne budy, w których baby zaczęły ustawiać swe kociołki z barszczem i pierogami, osiadał na bańkach z mlekiem, które żydowski handlarz targał na dwukołowym wózku z mleczarni Estery Fisch [...]" (Krajewski 2010: 13).

${ }^{11}$ „W dyżurce zapadła cisza. Wszyscy z wielkim zainteresowaniem obserwowali komisarza. Ten przeglądał powoli kartkę za kartką, raport za raportem. Ta cisza najszybciej znudziła się rusińskiemu rolnikowi. Wykorzystał to, iż nikt na niego nie zwraca uwagi, i pogroził Żydowi, uderzając się lekko potężną pięścią w podbródek. — Her policaj! — wrzasnął starozakonny. — Der cham macht a kłótnie! Der cham hat kaczkie giesztiłen! — Czoho ty, Żydu, mene chamom nazywajesz?! — Rusin nacisnął na głowę futrzaną czapę i ruszył groźnie na swojego przeciwnika. - W polskim urzędzie mówić po polsku! - krzyknął posterunkowy i spojrzał na Popielskiego, oczekując aprobaty dla swojego wystąpienia; nie uzyskawszy jej, krzyknął jeszcze głośniej”. (Krajewski 2010: 143)

${ }^{12}$ Jak podaje Wacław Wierzbieniec, wśród żydowskiej populacji Lwowa inteligenci stanowili 20\%. Liczebność tej grupy była konsekwencją silnego procesu asymilacji ludności żydowskiej Lwowa, którego początki przypadają na II połowę XIX stulecia. Żydzi tworzyli ponadto liczną grupę lwowskiego drobnomieszczaństwa (Wierzbieniec 2000: 316). 
zawodów spotykają się w kawiarni, żywo dyskutując o wydarzeniach bieżących, aczkolwiek w niedzielę nie naruszają szabasu. Jak relacjonuje narrator:

W Wiedeńskiej przy placu Mariackim w niedzielne popołudnia panował duży ruch. Dzisiaj kawiarnię zapełniali głównie zamożni Żydzi, którzy w odróżnieniu od swoich chrześcijańskich współobywateli nie śpieszyli do lwowskich kościołów, gdzie odbywały się uroczyste sumy. Bywalcy lokalu spożywali o tej porze czekolady, ciastka i owoce w rodzinnym gronie i na ogół należeli do zamożnej i liberalnej inteligencji. Pobożnych Żydów nie było tu wielu, ponieważ unikali oni wszelkich kontaktów ze swoimi wolnomyślicielskimi pobratymcami. (Krajewski 2009: 238-239)

Wśród reprezentantów akulturacji Krajewski eksponuje postać współpracownika komisarza Popielskiego - Hermana Kacnelsona ze zasymilowanej prawniczej rodziny. Pragnie on dokonać samoidentyfikacji narodowej, przeszkadza mu jednak nałożone na niego „piętno żydowskie” związane z imieniem, a także narzucona przez innych tożsamość, którą chciałby wyprzeć. Byłby zatem Herman Kacnelson przykładem mechanizmu samonienawiści zdiagnozowanej przez Sandera Gilmana? Nie może on uciec od swojej żydowskiej tożsamości, gdyż nawet koledzy w pracy po kryjomu nazywają go „Gudłajkiem”. W myśl sformułowanej przez Gilmana koncepcji samonienawiści, Żydzi pragnący akceptacji w środowisku grupy dominującej przyjmują za własny stworzony przez nią fantazmatyczny wizerunek Innych, który jak każdy stereotyp ma dwojakie oblicze. Aprobują w nim to, co wydaje im się słuszne, a to, co złe, projektują na tych, których porzucili (Gilman 1990: 4-5).

To między innymi oczami Kacnelsona obserwujemy świat ortodoksji we Lwowie, przestrzeń chederów i domów modlitwy, zatem widoczna w jego postawie awersja jest tu oczywista.

Rozmowy z przedstawicielami religijnych środowisk żydowskich, w których pieczy leżały bursy, napawały go niechęcią. Widząc brudne salki modlitw przy synagogach, chłopców kiwających się w chederowych ławkach, wyświechtane chałaty i jarmułki starozakonnych oraz peruki pobożnych Żydówek, słuchając wywodów w nieznanym mu jidysz, czuł, że się cofa w mrok nieznanego świata, a jego logiczny i racjonalny umysł, wyćwiczony na nieukończonych studiach politechnicznych, zalewają męty jakiś odwiecznych zabobonów. (Krajewski 2009: 137)

$\mathrm{U}$ tego bohatera każde, nawet najmniejsze skojarzenie $\mathrm{z}$ pochodzeniem wywołuje reakcję. Cierpi on na przewrażliwienie właściwe dla osób, których tożsamość jest niestabilna i muszą one szukać oparcia w opinii innych. Nic więc dziwnego, że na prośbę naczelnika Kocowskiego o translację hebrajskiego zdania, aspirant Kacnelson reaguje agresją: 
— To, że noszę dziwne nazwisko — odparł gniewnie zapytany, nawet nie patrząc na wycinankę — nie znaczy, że muszę znać hebrajski. Być może mam jakiś żydowskich przodków jak wielu Polaków! A moja nieszczęsne imię Herman jest, jak pan naczelnik doskonale wie, niemieckie, nie żydowskie. (Krajewski 2011: 49)

Choć trudno uznać, że taka była intencja autora, można pokusić się o domysł, że podkreślanie przez aspiranta polskiej narodowości ma głębsze przyczyny. Choć w latach trzydziestych XX wieku Żydzi we Lwowie dominowali w niektórych wolnych zawodach — w medycynie czy prawie, jednak w niewielkim procencie zatrudnieni byli w instytucjach państwowych. W więziennictwie i policji nie stanowili nawet jednego procenta. Byli niechętnie zatrudniani w strukturach bezpieczeństwa państwa, a reminiscencje walk o Galicję Wschodnią u progu niepodległości były tu jednym z decydujących czynników (Wierzbieniec 2000: 313). Natomiast nielubiane przez bohatera imię Herman może być pozostałością po drugim (obok polskiego) niemieckim modelu akulturacji, chętnie przyjmowanym przez inteligencję żydowską Lwowa w drugiej połowie XIX wieku po ogłoszeniu konstytucji dającej równe prawa wszystkim obywatelom Austro-Węgier (Kopff-Muszyńska 1992: 187). Z czasem, także na skutek transformacji geograficznych i umiejscowienia Lwowa w granicach Rzeczpospolitej, dominująca pozycja przypadła kulturze polskiej.

W Liczbach Charona, gdzie motyw oparty na wprowadzeniu hebrajskiego alfabetu i związanych z nim jakości liczbowych odgrywa znaczącą rolę, do rozszyfrowania zagadki potrzebni są rabin, profesor uniwersytetu, Popielski, a nawet zwykły Żyd, znający hebrajski. Zastanawia już sam fakt włączenia tego właśnie języka w obręb kryminalnej intrygi prawdopodobnie ze względu na korespondencję alfabetu i matematyki, a także przypisywaną mu od dawna, chociażby w kabalistyce, tajemniczość. Celem wyjaśnienia kwestii Krajewski wprowadza mikrowykład na temat roli starożytnego języka hebrajskiego w historii, przy czym wypowiadający się na ten temat bohaterowie używają adekwatnej dla swojego kręgu kulturowego terminologii. Znawca starożytności profesor Kuryłowicz mówi więc o roli hebrajszczyzny w powstaniu Starego Testamentu. Nie używa przy tym nazwy „Tora” właściwej dla tradycji judaizmu, lecz odwołuje się do tradycji chrześcijańskiej. Informuje również, iż język hebrajski używany dotychczas w liturgii judaistycznej, obecnie odradza się w syjonizmie, co niewątpliwie stanowi naddatek edukacyjny. Dodaje także, zapewne w intencji autorskiej uświadamiając czytelnika:

Mówimy w skrócie ,język hebrajski”, mając na myśli przede wszystkim Stary Testament. Nie zapominajmy jednak, że w tym języku w starożytności powstała bogata literatura rabiniczna, na przykład midrasze. (Krajewski 2011: 69) 
Odsyła więc badającego sprawę aspiranta do rabina Pinchasa Schatzekera, znawcy literatury biblijnej. Co ciekawe rabin, mówiąc o hebrajszczyźnie zapisu, odwołuje się do Tory, używa zatem właściwej dla siebie leksyki. Rabin jest przyjacielem księdza doktora Tadeusza Mazura, sekretarza arcybiskupa Twardowskiego, co stanowi punkt wyjścia do kolejnego odniesienia. Jak podaje narrator:

Przyjaźń ta oficjalnie scementowana była wspólnotą zainteresowań badawczych, a mniej oficjalnie, wspólnym zamiłowaniem do księżowskich nalewek. Obaj panowie nader chętnie się nimi raczyli, dyskutując przy tym o onomastyce palestyńskiej lub o możliwościach asymilacji mniejszości żydowskiej w Polsce, którego to zjawiska rabin Schatzker był zdecydowanym orędownikiem. (Krajewski 2011: 84)

Zdanie to jest na tyle enigmatyczne, że nie pozwala wskazać, jakie poglądy ma ksiądz Mazur. Można domniemywać, że podziela poglądy rabina. W takim przypadku byłby faktycznie uczonym mężem, godnym przyjaźni, albowiem podobne zachowanie nie było częste $\mathrm{w}$ środowiskach katolickich $\mathrm{w}$ okresie międzywojennym. Choć Kościół potępiał antyżydowską przemoc, nie stronił jednak od postulatów separatyzmu Polaków i Żydów w różnych dziedzinach życia społecznego ${ }^{13}$. Wielu duchownych nie ufało też asymilacji, chyba że zakończonej chrztem (Pałka 2006: 171). Taka prezentacja zażyłości wyznawców dwóch religii wprowadza więc złudzenie symbiozy, harmonii, wzajemnych dobrych stosunków. O ile faktycznie mogły one występować w mikroskali, w makro były raczej mało prawdopodobne.

Dalszych analiz hebrajszczyzny dokonuje już Edward Popielski, opierając się na cyfrowym zapisie wartości hebrajskich liter. Ostatecznie ich układ rozszyfrowuje rabin Schatzker, a trop, już dzięki wnikliwości Popielskiego, prowadzi do podejrzanego - hrabiego Bekierskiego i jego matki Chai Lejbach. Ten epizod wprowadza kwestię konwersji, albowiem Chaja Lejbach została w wieku dorosłym adoptowana przez szewca Adama Lipowskiego i jego żonę Walerię. Jako Hanna Lipowska wyszła za mąż za Antoniego hrabiego Bekierskiego, a z tego związku urodził się Józef Maria Bekierski, późniejszy prześladowca Popielskiego. Tę historię o kopciuszku uwiarygodnia jedynie podanie profesji przyszłej hrabiny, która trudni się aktorstwem, co stawia ją niejako poza sztywnymi ramami kastowego społeczeństwa. Wiadomo jednakże, że nie była ona gwiazdą najważniejszych scen teatralnych we Lwowie czy też Monarchii Austro-Węgierskiej, co czyni tę wersję już mniej prawdopodobną.

${ }_{13}$ Warto przywołać tu list pasterski prymasa Augusta Hlonda z 1936 roku, w którym przestrzegał przed przemocą antysemicką, zalecał jednak bojkotowanie sklepów żydowskich i popieranie rodzimych wytwórców. Więcej na ten temat patrz Pałka 2008: 238. 
Fakt biograficzny daje jednak asumpt dla zemsty Popielskiego. Ujawnia on w prasie pochodzenie Bekierskiego, mając nadzieję, że wiadomość dotrze do jego kompanów, członków Stronnictwa Narodowego i zniweczy plany polityczne hrabiego. Tym samym Krajewski wprowadza wątek „matki Żydówki” wykorzystywany przy atakowaniu zagorzałych endeków przez przeciwne im liberalne środowiska. Wystarczy przypomnieć kampanie „Wiadomości Literackich” i prześmiewcze poszukiwanie dziadka Wojciecha Wasiutyńskiego, wybitnego działacza endecji czy matki Stanisława Piaseckiego, wydawcy „Prosto z mostu” (patrz szerzej Domagalska 2004: 108).

W kryminałach Marka Krajewskiego nie brakuje też obrazków z lwowskiego półświatka, a lwowskie spelunki oblegane są przez Żydów załatwiających tu swoje interesy. Komisarz wkracza więc do „Morskiej groty”, miejsca spotkań lokalnych przestępców przy ulicy Dominikańskiej w centrum miasta. Nie ma tam narodowościowych sporów, a ofiarami bywają zarówno Polacy, jak i Żydzi. Jednak hersztem bandy, sprowadzającej także nieszczęście na wnuka Popielskiego — Jerzyka jest Żyd Mosze Kiczałes. To on uprowadza dziecko, które następnie zostaje porwane przez Cyganów ${ }^{14}$. Co prawda Popielski mści się w straszny sposób na inspiratorze zbrodni, ale nigdy już nie odzyskuje wnuka. Także los córki Popielskiego jest konsekwencją tego wydarzenia, albowiem, nie upilnowawszy syna, popada ona w obłęd i po wybuchu wojny zostaje zabita przez Niemców likwidujących zakład dla nerwowo chorych.

O ile wcześniejsze wątki mające na celu wprowadzenie kolorytu lokalnego zasługują na uznanie ze względu na wieloaspektowość, o tyle konstrukcja wątku porwania budzi wątpliwości, podobnie jak scena morderstwa dziecka, rozpoczynająca lwowską serię przygód Popielskiego. Początek fabuły ujawnia sytuację, której rozwikłanie nastąpi w kolejnych częściach serii. Oto w sławojce, na lwowskim podwórku znaleziono zwłoki chłopca. Trudno powiedzieć, czy opis ran kłutych na ciele dziecka powoduje u współczesnego czytelnika powieści popularnej jednoznaczne skojarzenia. Jeśli tak, Krajewski zakłada, że mit mordu rytualnego jest rozpowszechniony i wpisany w społeczną świadomość. Podkomisarzowi Pirożkowi, otwierającemu drzwi ustępu, jawi się następujący widok:

Nigdy czegoś takiego nie widział. Chore, kostropate, połamane dziecko, Ma, na oko, nie więcej niż trzy lata. Wyprostował się, splunął i jeszcze raz spojrzał na ciało. To nie były strupy. To były rany kłute. (Krajewski 2009: 14)

${ }^{14}$ Ten schemat walterscotowski typowy jest także dla polskiej literatury. Cyganie jako sprawcy porwania funkcjonują jako liczman literacki, np. w Malwinie Marii Wirtemberskiej. 
Autor, co oczywiste, nie przypisuje głównym bohaterom myśli o dokonaniu mordu rytualnego, odnotowuje jednak krążące na ten temat pogłoski. Sądy kuzynki Popielskiego Leokadii Tchorznickiej, osoby wykształconej i inteligentnej, układa we frazę: „Odmówiłeś śledztwa w sprawie tego chłopca, o którym pospólstwo powiada, że został rytualnie zamordowany przez Żydów" (Krajewski 2009: 18).

Wypowiedź, nawet jak na kuzynkę Leokadię, jest zbyt długa i brzmi sztucznie. Skojarzenie: dziecko oraz mord popełniony przez Żydów byłoby wystarczającym komentarzem do zachowania pospólstwa, tym bardziej, że sprawa Ritterów z 1881 roku odbiła się we Lwowie szerokim echem ${ }^{15}$. Krajewski, wprowadzając naddatek informacyjny, chce zatem podkreślić fałsz społecznych wyobrażeń i zasygnalizować, że funkcjonują one w obiegu lokalnym. Sygnałem wyczuwalnego lęku jest zachowanie aptekarza i jego żony po odkryciu zwłok dziecka. Czytelnik domyśla się pochodzenia małżonków jedynie na podstawie nazwiska. Może się zatem zastanawiać, w zależności od stanu swojej wiedzy, czy żona aptekarza znajduje się na granicy histerii z powodu strasznego morderstwa czy z obawy przed potencjalnymi jego konsekwencjami.

Niemalże natychmiast sprawa zyskuje szerszy wymiar, a z zagrożenia zdaje sobie sprawę arcybiskup i to on dookreśla pochodzenie aptekarza. Jego ustami jest także wyrażone stwierdzenie o absurdalności oskarżeń. Być może autor daje tu szansę przedstawicielowi Kościoła na symboliczną ekspiację, wszak ta instytucja $\mathrm{w}$ rozpowszechnianiu mitu mordu rytualnego odegrała w historii niemałą rolę (Węgrzynek 2005: 25). Dostojnik ma także świadomość, że część kleru i wiernych, przekonanych o prawdziwości mitu ulegnie sugestii. Świadomy tragicznych skutków podobnych oskarżeń arcybiskup wyjaśnia zagrożenie:

— Nie tylko „Słowo” ma swoich informatorów, chłopcze. My mamy lepszych. Wiemy, jak się nazywa ten aptekarz — powiedział, otworzył teczkę i poprawił okulary na nosie. - Adolf Aschkenazy. Tak się właśnie nazywa. I mimo że wszystkie gazety były posłuszne nakazowi policji i żadna nie podała nazwiska tego człowieka, jutro będzie je znał cały Lwów, jeśli nie cała Polska. Otóż jutro wszyscy będą wiedzieć, że Izraelita Adolf Aschkenazy znalazł w swym ustępie chrześcijańskie dziecko z wieloma ranami od noża. Wiesz, co to znaczy? Młody duchowny aż powstał z krzesła. — Tak... Nie, to nie może być. — Ksiądz Fedusiewicz nie mógł opanować drżenia rąk i nerwowych

${ }^{15}$ W 1881 roku we wsi Lutcza znaleziono zwłoki Franciszki Mnich. O popełnienie morderstwa oskarżono Mojżesza Rittera i jego żonę Gitlę, u których denatka pracowała jako służąca. Ritterowie zostali zwolnieni z więzienia w 1886 roku po ostatecznym wyroku Najwyższego Trybunału w Wiedniu, który w tej sprawie obradował po raz trzeci. Na posiedzeniu Sejmu Krajowego we Lwowie komentował ją z antysemickiej perspektywy poseł Teofil Merunowicz, współpracownik „Gazety Narodowej”, na której łamach szerzono pogląd, że podłożem zbrodni był fanatyzm religijny. Por. Żyndul 2011: 150-157. 
ruchów ramionami. — Przecież nikt nie uwierzy, że żydowski aptekarz popełnił mord rytualny na katolickim dziecku, a potem zawiadomił policję! To niemożebne! — Ludzie nie w takie rzeczy uwierzyli. — Arcybiskup podszedł do młodego człowieka i położył mu rękę na ramieniu ${ }^{16}$.

Krajewski kreuje poczucie zagrożenia, atmosfera pogromowa wisi na włosku ${ }^{17}$. Komisarz Popielski i jego współpracownicy mają świadomość, czym grozi brak wskazania winnego:

— Żydzi zamykają się w swych domostwach — powiedział, jakby do siebie, wycierając mokre dłonie o spodnie. - W komisariacie na Kurkowej zamknięto bezrobotnego z bańką nafty. Złapano go przy synagodze Złota Róża. Czas nas goni, doktorze. (Krajewski 2010: 37)

O pomoc w odnalezieniu mordercy dziecka Popielski zwraca się do króla lwowskiego podziemia Mosze Kiczałesa. On także, podobnie jak Kacnelson, czuje się oburzony, że z powodu pochodzenia ma przyczynić się do wytropienia zbrodniarza, co jakoby potwierdza insynuację. Popielski jednak dementuje ten tok jego myślenia:

— Niech pan znajdzie mordercę tego dziecka i odda go mnie — powiedział Popielski cichym głosem, wskazując na gazetę, na której pierwszej stronie umieszczone było jego zdjęcie. - Myśli pan tak jak wszyscy, nu nie? Że to Żyd zabił chrześcijańskie bambulko na macy, nu nie? I dlatego ja, Żyd, mam go szukać wśród niby swoich, co? Chcesz mnie pan wziąć pod włos, co? Boisz się pan rozruchów, pogromu Żydów? Nie obchodzi mnie, jaka jest narodowość mordercy, rozumie pan, Kiczałes — odpowiedział zimno Popielski. (Krajewski 2010: 30)

${ }^{16}$ Arcybiskup dodaje także:

„-Wiesz, chłopcze, jak bardzo cenimy twoją pracę z młodzieżą pro publico bono? - , Dziękuję, Ekscelencjo — wyszeptał ksiądz Fedusiewicz. — Twój ciężki codzienny znój z tymi młodymi, poszukującymi prawdy i żarliwymi duchami — ciągnął arcybiskup. — Z tymi radykalnymi akademikami, którzy są czasami tak zapalczywi, tak owładnięci szlachetnymi ideami narodowymi, że sięgają po metody gwałtowne, których my nie pochwalamy. Ty, jako duszpasterz mający najbliższy kontakt z tymi młodzieńcami, potrafisz ich poskromić, potrafisz skierować ich entuzjazm na właściwe tory. Wiesz, dlaczego cię zaprosiliśmy? — Podszedł do biurka i stuknął palcem w gazetę. — Dlatego. Zrób wszystko, aby zapobiec radykalizacji nastrojów wśród akademików. Zdradź im nazwisko aptekarza i przemów do rozsądku — skrzywił się, jakby rozbolał go ząb — zanim niektórzy księża w najbliższą niedzielę oskarżą Żydów o mord rytualny na chrześcijańskim dziecku. To wszystko" (Krajewski 2010: 18-19).

17 Warto pamiętać, że od pogromu lwowskiego, który miał miejsce podczas walk o miasto w listopadzie 1918 roku nie minęło wiele czasu, a pamięć ofiar i wzajemnych oskarżeń była wciąż żywa. Na temat pogromu lwowskiego patrz Tomaszewski 1975: 279-285; Różański: 2004: 347-358; Tramer 2013: 121-137. 
Zagadka zamordowania dziecka nie zostaje rozwiązana w pierwszej części przygód komisarza Popielskiego. Budzi to niepokój, albowiem czytelnik niekoniecznie musi zagłębić się w lekturę następnej części, która przynosi rozwiązanie. Autor pozostawia go zatem z pytaniem i jedynie delikatną sugestią Leokadii, że plotka o mordzie rytualnym krąży wśród mieszkańców Lwowa. Jest to jednak informacja zbyt powierzchowna, wziąwszy pod uwagę fakt, że tego rodzaju insynuacja miała zazwyczaj daleko idące reperkusje, a konsekwencją była śmierć niewinnych Żydów. Ponadto po traumie Holokaustu wprowadzanie bohatera żydowskiego jako kidnapera, wspomaganego przez mniejszość romską, uaktywnia klisze, które powinny zniknąć ze społecznej pamięci. Niewątpliwie czytelnik koncentruje się na nieszczęściu komisarza Popielskiego, ale wie również, kto za nim stoi. Taka sugestia współcześnie chyba nie jest już potrzebna. Krajewski próbuje rozprawić się z mitem mordu rytualnego. $Z$ godną podziwu uważnością odtwarza nie tylko wieloetniczność Lwowa, pogranicze kultur, ale i zróżnicowanie żydowskiej społeczności. Dostrzega nie tylko świat ortodoksów, ale i integracjonistów z wieloma niuansami ich egzystencji. Można jednak przyjąć, że utalentowanego pisarza - uważnego rekonstruktora unicestwionego pożogą wojenną świata, twórcę postaci komisarza Popielskiego — stać byłoby na ostrożniejsze operowanie materiałem, który wymaga uwagi także, a może przede wszystkim na kartach popularnych powieści. To prawda, że nie służą one dydaktyce, ale ze względu na swoją poczytność mogą pełnić istotną rolę w procesie „mierzenia się z delikatną i wciąż jeszcze nieprzepracowaną materią, jaką w polskim dyskursie publicznym jest rozliczanie się ze stereotypów, legend i przemilczeń determinowanych historią relacji polsko-żydowskich" (Więckowski 2015: 69). Twórcy beletrystyki mają w swoich rękach potężne narzędzie, które może pomóc w obnażaniu fałszu etnicznych mitów i społecznych wyobrażeń. Od nich tylko zależy, jak go użyją.

\section{BIBLIOGRAFIA}

Antosik-Piela Maria. 2011. Sentymenty i stereotypy. Świat żydowski w kryminatach retro. „Cwiszn” 2011, nr 4. S. 108-110.

Ascheim A. Steven. 1982. Brothers and Strangers. The East European Jew in German and German Jewish Consciousness, 1800-1923. Madison: The University of Wisconsin Press.

Barańczak Stanisław. 1973. Poetyka polskiej powieści kryminalnej. „Teksty” 1973, nr 6. S. 63-82.

Borowczyk Jerzy, Larek Michał. 2009. To miasto wotato do mnie w innym jezyku. Z Markiem Krajewskim rozmawiaja... „Czas Kultury” 2009, nr 1. S. 89-102.

Browarny Wojciech. 2010. Dyskretny urok mieszczańskiego demonizmu (powieści Marka Krajewskiego). „Studia Filmoznawcze” 2010, nr 31. S. 245-258. 
Brylla Wolfgang. 2016. Polski kryminat retro. Między innowacja, naśladownictwem a literackim kiczem. „Zeszyty Naukowe Uniwersytetu Zielonogórskiego. Scripta Humana” 2016, t. 5. S. 223-236.

Dobek Tomasz Daniel. 2008. Dokąd idziesz Retro — rzecz o polskim kryminale historycznym. „Dekada Literacka” 2008, nr 1. S. 10-16.

Domagalska Małgorzata. 2004. Antysemityzm dla inteligencji? Kwestia żydowska w publicystyce Adolfa Nowaczyńskiego na tamach "Myśli Narodowej” (1921-1934) i "Prosto z mostu” (1935-1939): (na tle porównawczym). Warszawa: Żydowski Instytut Historyczny.

Döblin Alfred. 2000. Podróż po Polsce. Tłum. Anna Wołkowicz. Kraków: Wydawnictwo Literackie.

Geller Ewa. 1994. Jidysz. Język Żydów polskich. Warszawa: Wydawnictwo Naukowe PWN.

Gilman L. Sander. 1990. Jewish Self-Hatred. Anti-Semitism and the Hidden Language of the Jews. Baltimore-London: The John Hopkins University Press.

Gilman L. Sander. 1991. The Jew's Body. Routledge: Routledge Taylor \& Francis.

Heissenbüttel Helmut. 1973. Reguty gry powieści kryminalnej. „Teksty” 1973, nr 6. S. 44-62.

Kopff-Muszynska Katarzyna. 1992. „Ob Deutsch oder Polnisch”- przyczynek do badań nad asymilacja Żydów we Lwowie w latach 1840-1892. W: The Jews in Poland. Red. Andrzej K. Paluch. Kraków: Jagiellonian University, Research Center on Jewish History and Culture in Poland. S. 187-203.

Krajewski Marek. 2009. Gtowa minotaura. Warszawa: Wydawnictwo W.A.B.

Krajewski Marek. 2010. Erynie. Kraków: Społeczny Instytut Wydawniczy Znak.

Krajewski Marek. 2011. Liczby Charona. Kraków: Społeczny Instytut Wydawniczy Znak.

Krupa Bartłomiej. 2008. Poetyka powieści Marka Krajewskiego. „Poznańskie Studia Polonistyczne" 2008, nr 14/15. S. 143-163.

Medecka Małgorzata. 2013. ZakazanelZapomniane pogranicza kultur w powieści kryminalnej i apokryfie rodzinnym. „Zeszyty Naukowe KUL” 2013, nr 4. S. 23-35.

Ostaszewski Robert. 2008. Miasto mój bohater (i nie tylko). „Dekada Literacka” 2008, nr 1. S. 17-22.

Pałka Damian. 2008. Kościót katolicki wobec Żydów w Polsce międzywojennej. Kraków: Nomos.

Prokop-Janiec Eugenia. 2005. „Kwiaty wschodnie”. Tematy żydowskie wobec orientalizmu. W: Problematyka żydowska $w$ romantyzmie polskim. Red. Andrzej Fabianowski, Maria Makaruk. Warszawa: Wydział Polonistyki Uniwersytetu Warszawskiego. S. 91-108.

Różański Przemysław. 2004. Pogrom lwowski 22 listopada 1918 roku w świetle zeznań Organizacji Syjonistycznej przed Komisja Morgenthaua. „Kwartalnik Historii Żydów” 2004, nr 3. S. 347-358. 
Steckiewicz Maryna. 2014. Echa żydowskiej ulicy. O obecności języka jidysz w kryminale retro. „Studia Judaica” 2014, nr 1. S. 109-124.

Szybowicz Eliza, Warkocki Błażej. 2010. Mock w mieście potworów. „Krytyka Polityczna” 2010, nr 20-21. S. 71-78.

Tomaszewski Jerzy. 1975. Lwów, 22 listopada 1918. „Przegląd Historyczny” 1975, nr 2. S. 279-285.

Tomaszewski Jerzy. 1993. Niepodlegta Rzeczpospolita. W: Najnowsze dzieje Żydów w Polsce. Red. Jerzy Tomaszewski, Warszawa: Wydawnictwo Naukowe PWN. S. 143-269.

Tramer Maciej. 2013. Leopolis tantum fidelis (o pogromie lwowskim 1918). W: Żydzi Wschodniej Polski: świadectwa i interpretacje. Białystok: Wydawnictwo Alter Studio. S. 121-137.

Węgrzynek Hanna. 1995. „Czarna legenda” Żydów: procesy o rzekome mordy rytualne $w$ dawnej Polsce. Warszawa: Wydawnictwo Bellona.

Wierzbieniec Wacław. 2000. Ludność żydowska Lwowa w okresie II Rzeczypospolitej. W: Historia, archiwistyka, ludzie: księga pamiątkowa w pięćdziesiątą rocznicę powotania Archiwum Państwowego w Rzeszowie. Red. Jan Basta, Grzegorz Zamoyski. WarszawaRzeszów: Archiwum Państwowe w Rzeszowie. S. 289-317.

Więckowski Robert. 2015. Śledztwo w osnowie stereotypu, legendy i przemilczenia. Wątki żydowskie w polskich wspótczesnych powieściach sensacyjnych. „Kultura Popularna” 2015, nr 3. S. 66-76.

Wodziński Marcin. 2008. Jidysz a modernizacja. Język jidysz w myśli polskiej haskali i jej spadkobierców. W: Jidyszland, polskie przestrzenie. Red. Ewa Geller, Monika Polit. Warszawa: Wydawnictwo UW. S. 243-262.

Ziątkowski Leszek. 2000. Dzieje Żydów we Wroctawiu. Wrocław: Wydawnictwo Dolnośląskie.

Zieliński Henryk. 1985. Historia Polski 1914-1939. Wrocław: Zakład Narodowy im. Ossolińskich.

Zimna Justyna. 2009. Filologia zbrodni. Dwóch bohaterów Marka Krajewskiego. „Czas Kultury" 2009, nr 1. S. 102-107.

Żyndul Jolanta. 2011. Ktamstwo krwi. Legenda mordu rytualnego na ziemiach polskich w XIX i XX wieku. Warszawa: Wydawnictwo Cyklady. 
Matgorzata Domagalska

\title{
CRIME IN MULTIETHNIC LVOW. JEWS IN MAREK KRAJEWSKI'S CRIME STORIES
}

\author{
(summary)
}

Recently there has been a boom in Polish popular novels. One of the most widely read genres are crime stories whose plot is set in the interwar Poland, in which the authors must take into consideration the demographics of that time. One of the most popular authors and pioneer of this type of crime stories is Marek Krajewski. In this article, I analyze his cycle of novels about detective inspector Popielski (Gtowa Minotaura, Erynie, Liczby Charona) the plots of which are set in pre-war Lvow. I study how Krajewski presents the diversity of the Jewish minority and the types of clichés or stereotypes he uses. I especially focus on the myth of ritual murder and try to consider if this representation is legitimized, taking into consideration that the highly readable popular novel is an important tool to shape or modify ethnic myths and imageries.

\section{KEYWORD}

Marek Krajewski; crime story; Lvow; Polish-Jewish relations; myth of ritual murder 

Prace Polonistyczne, seria LXXII, 2017

ISSN: 0079-4791; e-ISSN: 2450-9353

DOI: $10.26485 / \mathrm{PP} / 2017 / 72 / 6$

Maria Gotębiewska

\section{PIERWIASTEK PAŁUBICZNY, KONSTRUKCJA I AKULTURACJA W „PAŁUBIE” KAROLA IRZYKOWSKIEGO}

\section{SŁOWA KLUCZOWE}

pałuba; natura; konstrukcja; enkulturacja; akulturacja

[U]siłowaniem moim w Patubie jest docierać wciąż do tych warstw życia, gdzie ono abstrakcji urąga, spod uogólnień się usuwa i objawia się jako trudne do rozwikłania, rozpaczliwe, wyjątkowe ${ }^{1}$.

Karol Irzykowski

Celem tekstu jest omówienie koncepcji „pałubiczności” Karola Irzykowskiego w zestawieniu z jego koncepcją "konstrukcji”. Obu wymienionych terminów używa on w Patubie (1903), gdzie charakteryzuje „pierwiastek konstrukcyjny”, odwołując się do tez empiriokrytycyzmu Richarda Avenariusa i Ernsta Macha². Jednak zagadnienie konstrukcji, przede wszystkim pojętej epistemologicznie i psychologicznie, było obecne w tezach Immanuela Kanta, Johanna G. Fichtego i Friedricha W.J. Schellinga, a zostało szerzej upowszechnione dzięki

Maria Gołębiewska — profesor nadzwyczajny w Zespole Filozofii Kultury Instytutu Filozofii i Socjologii PAN; e-mail: mgolebie@ifispan.waw.pl

1 Irzykowski 1981: 151 (rozdział VIII Naturam expellas furca...). Tytuł rozdziału to początek zdania Horacego, które stało się przysłowiem: „naturam expellas furca, tamen usque recurret” / „wypędzisz naturę widłami, a ona i tak powróci” — por. tamże, przypis 1 .

2 Tezy empiriokrytycyzmu były znane na przełomie XIX i XX wieku dzięki publikacji między innymi dwóch tomów Kritik der reinen Erfahrung (1880-1890) Richarda Avenariusa oraz Erkenntnis und Irrtum (1900) Ernsta Macha. 
neokantyzmowi i empiriokrytycyzmowi. Tezy dotyczące konstrukcji były żywo dyskutowane w czasie powstawania Patuby i następnych prac Irzykowskiego, w których również pojawia się zagadnienie konstrukcji rozpatrywane jako schematyzm poznania, jako to, co formalne i zestawione z treścią, jako konstrukcyjny aspekt komunikacji słownej i wizualnej (filmowej). Jego późniejsze prace dotyczą konstrukcji kulturowej jako zarazem konstrukcji formalnej, a powstają w czasie publikacji dzieł Ernsta Cassirera na temat symbolicznych form kultury. Jednak zagadnienie konstrukcji najpełniej jest omówione w Patubie, ujęte z pomocą określenia „pierwiastek konstrukcyjny”, który został przeciwstawiony temu, co „pałubiczne” („pierwiastek pałubiczny”).

Irzykowski zestawiając terminy „pałuba”, czyli to, co naturalne, bezpośrednie, zastane przez człowieka, i „konstrukcja”, czyli wytwarzany przez człowieka, specyficzny dla nas świat kultury, dookreśla byt ludzki, wskazuje prawidłowości ludzkiego działania, poznania i odczuwania. Zarazem dzięki terminowi „pałuba” ujmuje on to, co „naturalne” w obrębie kultury. Właśnie owo współistnienie naturalności i wytworów specyficznie ludzkich w obrębie świata kultury - świata, który anektuje to, co naturalne, obdarza „pałubę” sensami i znaczeniami - umożliwia enkulturację, czyli wprowadzenie „dzikiego” człowieka w obręb kultury, nauczanie i dostosowanie go do życia w kulturowym świecie, wypełnionym ludzkimi sensami i znaczeniami. Jednak zarazem pałubiczność jest tym, co zapośrednicza elementy naturalne (na przykład fizjologiczne) i kulturowe (na przykład to, co umysłowe) w obrębie jednostki, podmiotu doznań zmysłowych i przeżyć psychicznych, pasywnego odbiorcy bodźców i aktywnego współtwórcy świata społecznego. W takim przypadku jednostka odmienia własny świat społeczny, ale również dzięki akulturacji wchodzi w odmienne światy społeczne, a to wpływa między innymi na inne postrzeganie tego, co naturalne, na przykład własnej fizjologii. Obydwa wspomniane ujęcia pałubiczności jako kategorii pośredniczącej między tym, co naturalne a tym, co kulturowe odnajdujemy w Patubie Karola Irzykowskiego.

Głównym tematem tekstu jest zatem kategoria „pałubiczności”, której Irzykowski poświęca szczególną uwagę w kilku rozdziałach Patuby, przede wszystkim w rozdziale XI pierwiastek patubiczny (pisownia oryginalna) oraz w rozdziale XX Patuba. Według autora jest to kategoria niejednoznaczna, poniekąd graniczna, ponieważ ujmuje w ramach kultury pewne zachowania poza nią wykraczające, które jednak jako ludzkie wytwory przynależą do tego, co antropologiczne, a więc okazują się summa summarum kulturowe. Irzykowski charakteryzuje kategorie „pałuba” i „pierwiastek pałubiczny” w kontekście tez kulturalistycznych i historiozoficznych, przejętych od Georga W.F. Hegla i jego następców (filozofia życia Wilhelma Diltheya, Friedricha Nietzschego oraz 
Georga Simmla). Kategoria pałuby, obok kategorii konstrukcji, pozwala objaśnić stanowisko Irzykowskiego dotyczące wprowadzania jednostki w kulturę (enkulturacja „dzikiej” pałubiczności) oraz nabywania kompetencji z obszaru innej kultury, czyli akulturacji, łączonej przez niego z awansem społecznym, z aspiracjami kulturowymi oraz z cywilizacyjną modernizacją.

\section{Pierwiastek pałubiczny}

Tezy na temat relacji natury i kultury można odnaleźć w programie estetycznym i artystycznym naturalizmu czy też symbolizmu, oraz w programach Młodej Polski. Jednak naturalizm i program Młodej Polski przeciwstawiał naturę — jako to, co bezpośrednio dane podmiotowi — kulturze, jako temu, co konstruowane. Właśnie takiemu podziałowi, dostrzeganemu przede wszystkim w literaturze Młodej Polski, przeciwstawiał się Karol Irzykowski w Patubie i w komentarzach do niej, proponował bowiem krytyczne ujęcie tej opozycji. Irzykowski wskazywał niedostateczność i uproszczenie podziału ${ }^{3}$ na „pierwiastek pałubiczny” — naturalny, dziki, fizjologiczny, cielesny, twórczy, ale niezapośredniczony, oraz „pierwiastek konstrukcyjny" - kulturowy, wytwarzany, twórczy, ale zapośredniczony, a nawet „sztuczny” i w tym pomniejszy wobec natury. Wedle Irzykowskiego pierwiastek pałubiczny łączy się z tym, co "naturalne” w antropocentrycznej wizji świata, to znaczy z tym, co jest przez człowieka określane jako „natura” w obrębie specyficznego ludzkiego „świata życia” - kultury. Odniesienia do Diltheyowskiej koncepcji kultury utożsamianej z die Lebenswelt można wskazać jako obecne implicite w Patubie. Odnajdujemy tutaj obydwa ujęcia pałubiczności - i jako elementu przejściowego, pośredniczącego między tym, co naturalne i kulturowe w człowieku, i jako tego, co reprezentuje bezpośredniość „natury” (fizjologii, zmysłowości, emocji, „bogini Rzeczywistości”) w obrębie kultury i jej wytworów - reprezentacji mentalnych i komunikacyjnych, zapośredniczonych racjonalnie.

Charakterystykę pierwszej postaci pałubiczności odnajdujemy w wywodach Irzykowskiego, objaśniających sam termin „pałuba”: „Pawełek zasłyszał wśród domowników i chłopów słowo 'pałuba'. Tak nazywa się już to ogromny drewniany taran do zabijania pali w rzece, już to manekin służący do przymierzania sukni kobiecych, pospolicie zaś czepia się to słowo jako pogardliwy przydomek brzydkich, nieprzyjemnych bab, lecz jest w tym wypadku bardziej dokucz-

3 Można dodać, że niedostateczność podziału na „pałubiczne”, naturalne oraz konstruowane, kulturowe, i wskazywanie skomplikowanych relacji między tymi kategoriami w miejsce upraszczającej opozycji, odnajdujemy także w prozie Brunona Schulza, który również używał określenia „pałuba”. 
liwym niż strasznym" (Irzykowski 1981: 372)4. W przypisie Karol Irzykowski dodaje: „Linde w Stowniku podaje trzy znaczenia wyrazu 'pałuba' (łub, kadłub): 1) zasłona, nakrycie wozu; 2) pniak, kadłub (okrętu); 3) stara, złośliwa kobieta” (Irzykowski 1981: 372, przypis 8). Bliższe, narracyjne określenie znajdujemy w przedostatnim rozdziale książki (zatytułowanym, podobnie jak jej całość, Pałuba), bowiem pojawia się tam Kseńka Pałuba jako uosobienie pałubiczności: „Ukryty w krzakach obserwował, jak kilku pastuchów rozpaliło ogień na pastwisku i piekło przy nim groch, kartofle i rydze. Wtem opodal ukazała się jakaś kobieta z długimi rudymi włosami, twarzą bladą, oczyma błędnymi, a odziana w łachmany, przez które widać było nagie ciało. Usiadła ona także w pobliżu ogniska na ziemi, robiła do pastuchów różne niby to przymilające się grymasy i nieprzyzwoite gesty i prosiła, aby jej co zjeść dali. Oni jednak pluli w jej stronę, rzucali na nią grudami, nazywali ją Kseńką Pałubą i wreszcie, dawszy jej kilka spopielonych lub nie dopieczonych kartofli, odpędzili od ogniska. Była to wiejska wariatka” (Irzykowski 1981: 377). „A przecież w tym zjawisku było coś, czego nie rozumiał, coś odrębnego od wszystkich innych ludzi (bo początkowo nie wiedział, że to wariatka)” (Irzykowski 1981: 377). Spotkanie z „pierwiastkiem pałubicznym" okazuje się tutaj konfrontacją z dotychczasowymi przekonaniami na temat podziałów: natura - kultura, zwierzę - człowiek: „W oknie, tuż nad jego plecami, w obramieniu portiery klęczała na czworakach podobna do zwierzęcia straszna postać kobieca, odziana szmatami, jej rozczochrane rude włosy spadały z przodu tak, że zaledwie było można rozeznać twarz z oczami" (Irzykowski 1981: 387). „W zmierzchu nie widział jej dokładnie, była dlań podobną fantasmagorią, jaką się chwyta we śnie, lecz wnet wezbrała w nim taka zajadłość przeciw temu nadzwyczajnemu zjawisku, jakby ono było uosobieniem wszystkiego, czego się bał i nienawidził. Odczuwając instynktownie jego furię, cofała się przed nim, ale zawsze wyzywająco, jak zwierzę. Potrzeba uporania się z nią sam na sam, bez dopuszczenia innych świadków, jakby z własną tajemnicą, zdecydowała się w nim od razu. Dlatego chciał ją uchwycić i opanować" (Irzykowski 1981: 388). Irzykowski wprost określa tu pałubiczność jako to, co uwewnętrznione w człowieku, jako pewną kategorię psychologiczną pozwalającą odnosić się do własnej fizjologii ${ }^{6}$ (Irzykowski 1981: 197), ale również do nieświadomości i niezrozumiałości: „Takie było podziemne życie podziemnego

4 Rozdział XX Patuba.

5 Należy dodać, że imię Ksenia ma grecką etymologię — greckie słowo „ksenos” służyło określeniu tego, co obce, w szczególności obcego przybysza.

6 Piotr Strumieński, podobnie ,jak większa część współczesnych ludzi, był pod przygnębiającym wrażeniem odkryć fizjologicznych, lekarskich, do których jeszcze nikt nie stosował pierwiastka pałubicznego" - rozdział XI pierwiastek patubiczny. 
życia” (Irzykowski 1981: 207)7 ${ }^{7}$, skrywane życie wewnętrzne. Warto dodać, że Irzykowski będzie powracać do kategorii „podziemnego życia” między innymi w swoich komentarzach dotyczących psychoanalizy.

Trzeba przypomnieć, że w Patubie Irzykowski łączył erotykę z „pierwiastkiem pałubicznym", z realnością wymykającą się poznaniu i z nieświadomością, która trudno poddaje się racjonalnemu rozpoznaniu. Natomiast "garderobą duszy” nazywał w Patubie „miejsce, w którym się kryją wpół świadome, wpół musowe myśli z dziedzin kompromitujących, zanim się przebiorą w szatę, w której mogą już pokazać się światu” (Irzykowski 1981: 174)․ Jak interpretuje Aleksandra Budrecka, „podziemne życie” i „garderoba duszy” miały służyć ujawnieniu tego, co nieoczekiwane, wymykające się dotychczasowym schematom, by uniknąć „konfliktu między konstrukcją a rzeczywistością” (Budrecka 1981: XLIX), by pośredniczyć między „pierwiastkiem pałubicznym” a „pierwiastkiem konstrukcyjnym”. Wydobycie na jaw „podziemnego”, wewnętrznego życia to zarazem postulat introspekcji, łączący się z samowiedzą i samotnością, pojętą jako niezależność jednostki od wpływów i nacisków zbiorowości. Był to również postulat „kultury szczerości” i „kultury mądrości” (Irzykowski 1981: 361-362) ${ }^{9}$, do którego Irzykowski powrócił w swoich tezach na temat klerkizmu i indywidualistycznej postawy klerka.

Należy dodać, że określenie wyznaczników człowieka jako specyficznego bytu, czyli definicja antropologiczna Irzykowskiego miała za punkt wyjścia podstawowe filozoficzne rozróżnienie ducha i materii. Irzykowski pojmował ducha jako rozumną świadomość w ogóle, dusza zaś według niego jest „znakiem konwencjonalnym, którego się używa dla skrócenia, gdy ktoś chce zaznaczyć, że mówi o sumie zjawisk psychicznych. Nie ma bowiem 'duszy', są tylko zjawiska psychiczne” (Irzykowski 1981: 406) — pisał w Uwagach do „Patuby”. Podkreślał: "Słowa 'dusza' używam w starym znaczeniu, to jest jako urojonego substratu wszystkich naprawdę dostrzegalnych zjawisk psychicznych: wyobrażeń, myśli, uczuć, kojarzeń logicznych i nielogicznych i wszelkich przedmiotów duchowych albo uświadomionych, albo takich, które mogą być uświadamiane" (Irzykowski 1981: 405). Według Irzykowskiego relację ducha i materii, ich wzajemne związki dostrzegamy w egzystencji i w działaniach twórczych człowieka. Irzykowski zdaje się powtarzać ogólne tezy dualizmu metafizycznego i epistemologicznego, znane z pism innych dualistów (na przykład Kartezjusza i zwolenników kartezjanizmu), uwzględniając zarazem aktywistyczne tezy filozofii życia oraz elementy filozofii egzystencji, dotyczącej specyficznego bytu, jakim jest człowiek.

\footnotetext{
7 Rozdział XI pierwiastek patubiczny.

8 Rozdział IX O punktach wstydliwych i o garderobie duszy (kontrabandzie).

9 Rozdział XIX Trio autora.
} 
Człowiek zatem, z jednej strony, jest wydany sferze materialnej i „pierwiastkowi pałubicznemu", którego nie może opanować ani na zewnątrz, ani w sobie (własna cielesność oraz nieświadomość). Jednak zarazem to materia jest tworzywem i narzędziem realizacji przez człowieka tego, co duchowe, a znaczy to zarazem: rozumne, związane ze świadomością i samoświadomością. Wynikiem racjonalnych działań człowieka jest „pierwiastek konstrukcyjny” — pewne konstrukcje poznawcze, służące poznaniu i opanowaniu świata wraz z jego „pierwiastkiem pałubicznym”. Transcendencja sfery „ducha” — rozumnej świadomości w ogóle - jest więc dana poznaniu człowieka o tyle, o ile manifestuje się w rzeczywistości dostępnej nam poznawczo, w kulturowej rzeczywistości, łączącej to, co duchowe, czyli rozumne, z tym, co materialne, a więc „pałubiczne”.

W Patubie pojawia się opis Bogini Rzeczywistości, która ingeruje w racjonalny ład świadomości i intelektu. Byłaby to rzeczywistość w swym pierwiastku „fizykalnym”, materialnym, jeszcze nie ujętym poznawczo i nie przetworzonym w kulturze, ale również rzeczywistość wewnętrzna nieświadomości, to, co obce świadomości. „Pierwiastek pałubiczny polega między innymi na inkongruencji (nieprzystawaniu) obrazu w duszy, myśli, fantazji, teorii z odnośną rzeczywistością. Aby głębiej odczuć działanie pierwiastka pałubicznego, trzeba ustosunkować się do życia, wybiegać poza nie myślą, mieć plany pojmowania lub kształtowania go, wyrosłe czasem do tak zwanych idées fixes, lub mieć choćby jakieś żywiej, osobiście odczute szablony — wtedy nawiedza nas ten gość skryty, niepożądany, wyrzucany za drzwi”" (Irzykowski 1981: 208) ${ }^{10}$ — rzeczywistość wymykająca się poznawczym i kulturowym przedstawieniom. Irzykowski nazywa to „pałubicznym piętnem rzeczywistości” (por. Irzykowski 1981: 440, Uwagi do „Patuby”).

„Pierwiastek pałubiczny” jest też charakteryzowany jako poczucie obcości wobec samego siebie, nieświadomość jako to, co wymyka się i zagraża subiektywności („Wyrasta w coś niespodzianego, czego nie oczekiwał, coś swojego, ale nie jego" - Irzykowski 1981: 243) ${ }^{11}$. Trzeba podkreślić, że Irzykowski przeciwstawiał „pierwiastek pałubiczny” nie tylko poznaniu racjonalnemu, ale w ogóle możliwości ujmowania przez człowieka rozmaitych doświadczeń w reprezentacjach mentalnych, a również w przedstawieniach artystycznych o różnym stopniu spójności bądź uporządkowania treści. Irzykowski zakładał, że poznawcze działania człowieka, łączone ściśle z językiem i pojęciami ogólnymi, mają charakter racjonalny. Paradoksalnie, to właśnie w Patubie - w dziele literackim, językowym i artystycznym zarazem - usiłował zawrzeć charakterystykę elementów doświadczenia, które wymykały się dotychczasowym opisom. Dlatego nazywał „pałubizmem" to, co nieoczekiwane i nie podlegające planowaniu ani kontroli, a co

${ }^{10}$ Rozdział XII Tenże sam pierwiastek z wizyta u Gasztolda.

${ }^{11}$ Rozdział XIV Architektura. 
usiłował oddać w budowaniu postaci i ich cechach (por. Irzykowski 1981: 357) ${ }^{12}$. Jak pisał, Patuba to „improwizacja” pełna niespodzianek dla samego autora (Irzykowski 1981: 360), tekst podlegający „pierwiastkowi pałubicznemu” (Irzykowski 1981: 365), który można starać się przedstawić, ale bez pewności co do prawdy przedstawienia i bez możliwości poznawczej kontroli (Irzykowski 1981: 393) ${ }^{13}$.

Natomiast drugie ujęcie pałubiczności jako tego, co wewnątrzkulturowe znajdujemy właśnie w uwagach i objaśnieniach autorskich:

Korzystając z tego prawa, nazwałem swoją powieść Patuba — od tego momentu, w którym rozchwianie się tematowości w życiu uderzyło w Strumieńskiego z żywiołową, brutalną potęgą. Użyłem także nazwy: pierwiastek pałubiczny, chociaż wcale nie mam pretensji, by ją przyjęto powszechnie, bo sam uważam ją tylko za przejściowe ukształtowanie się mego sposobu patrzenia na świat. Zamiast mówić 'pierwiastek pałubiczny' mogłem powiedzieć także pierwiastek rektyfikacyjny, dementujący [...]: to, co samo nie jest do niczego podobne, powinno mieć także nazwę do niczego niepodobną, dziką i dziwną, nieuczesaną i nieprzyjemną — niewygodną do użycia, ale przeto i nie dającą się zatrzeć monetą. 'Pałuba' jest symbolem wszystkiego, co łamie urojoną linię wypadków od zewnątrz lub od wewnątrz, w formie brutalnej i niebezpiecznej albo wstydliwej i zawstydzającej, wszystkiego, co w człowieku jest wątpliwością i niepewnością, wyrzutem sumienia i poczuciem inkongruencji, grzechem przeciw Duchowi Świętemu i jego głosem zarazem, zleceniem z wieży egoizmu w potworną przepaść szczerości, przecięciem nerwu z sobą samym, a uczuwaniem nerwu świata - to symbol tych chwil, w których umysłowo traci się grunt pod nogami, najlepszych i najbardziej wartościowych w życiu, chwil największej przykrości i największego skupienia, chwil nagłego rozszerzenia horyzontu, chwil rozczarowania jako źródła nowych czasów, chwil hiperemocji i hiperoryginalności. (Irzykowski 1981: 391$)^{14}$

„Pierwiastek pałubiczny” jest tu zatem łączony z hiperbolą, emocjami i afektem — z pewnym pobudzeniem wewnętrznym, które ożywia podmiot, wystawiając go na oddziaływanie świata, ale przy jednoczesnym utrzymaniu subiektywnej odrębności. Natomiast "pierwiastek konstrukcyjny” jest związany z logiczną i naukową obiektywizacją, jednak kwestia przyszłości powinna być rozstrzygana w odwołaniu do obu tych elementów konstytutywnych dla człowieka i uczestniczących w konstytuowaniu ludzkiego świata, zwanego kulturą. W późniejszych pracach Irzykowski-klerk będzie już deklarował stanowisko racjonalizmu i emocjonalnego opanowania.

\footnotetext{
12 Rozdział XIX Trio autora.

13 Rozdział XXI Ostatnia wieżyczka nonsensu.

14 Rozdział XX Patuba.
} 
Można uznać, że Irzykowski w swej — wielokrotnie prezentowanej w Patubie — pochwale „Bogini Rzeczywistości” próbował argumentować za pewną sensownością rzeczywistości w jej stanie przedpojęciowym, za sensem danym wraz z bezładem i chaosem tego, co wykracza poza ludzkie racjonalne poznanie, choć jest postrzegane i odczuwane. Irzykowski bowiem zakładał, że owe „postaci” rzeczywistości są pewnym przejawem, manifestacją prymarnej, źródłowo jednej rzeczywistości - bytu. Byłoby to zatem metafizyczne stanowisko pluralizmu monistycznego i byłoby ono zgodne z metodologicznymi postulatami Irzykowskiego, przede wszystkim z tezami na temat komplikacjonizmu. Komplikacjonizm i teoria prawdy pojętej jako wielość oglądów zakładały właśnie pluralistyczny charakter bytu i złożoność świata, danego poznaniu (por. Irzykowski 1976: 143). Wskazywana przez Irzykowskiego realność materialna i fizykalna nie byłaby przedmiotem pełnego poznania, człowiek podlegałby jej niejako w przepływie zmysłowych bodźców, warunkowanych wyposażeniem gatunkowym („pierwiastek pałubiczny”), nie zaś kulturowo. Natomiast wówczas, gdy mamy do czynienia z poznaniem racjonalnym, wkracza element kulturowy („pierwiastek konstrukcyjny"), czyli reprezentacje kulturowe, komunikacyjne jako społecznie i kulturowo wytworzone sposoby, a nawet wzorce i normy ujmowania wyników percepcji, porządkowania jej danych (wrażenia) wraz z reprezentacjami mentalnymi (wyobrażenia, idee, pojęcia ogólne). Bowiem wedle Irzykowskiego i zgodnie ze stanowiskiem kulturalizmu wytworzone reprezentacje kulturowe, komunikacyjne wpływają na subiektywne uchwytywanie wyników percepcji w postaci reprezentacji mentalnych (na przykład wyobrażeń) wraz ze znaczeniami im przypisywanymi (,symbolizacje” w terminologii Irzykowskiego).

Kulturowa i społeczna sfera reprezentacji określana jest przez Irzykowskiego jako specyficznie ludzka rzeczywistość dana człowiekowi („pierwiastek konstrukcyjny”). To właśnie do niej Irzykowski wydaje się stosować termin „życie”, wykraczając poza witalistyczne koncepcje filozofii życia, z którymi polemizował (między innymi z Henri Bergsonem, także z witalistycznymi programami Młodej Polski). Inspiracja filozofią życia dotyczyła w szczególności samej koncepcji życia, pojętego jako naturalistyczny warunek ludzkiego „świata życia”, czyli kultury (tezy przejęte między innymi od Wilhelma Diltheya). Pojęcie życia uprawomocniałoby, zdaniem Irzykowskiego, tak związek człowieka ze światem przyrody, jak i ze światem kultury. Irzykowski, podobnie jak Georg Simmel, uważał i przyrodę, i dzieje za pewne projekty, uwikłane w myślenie potoczne, dialektycznie łączące byt i znaczenie. Właśnie dlatego zestawiał „pierwiastek konstrukcyjny” z "pierwiastkiem pałubicznym” — ze sferą rzeczywistości niepoddającej się poznaniu i działaniu człowieka, a której oddziaływaniu z kolei podlega człowiek. Jednak wiedza konstruowana nie tylko jest przeciwstawiona niewiedzy 
czy bezradności wobec tak pojętej rzeczywistości, ale Irzykowski przeciwstawia ją wstępnemu rozpoznaniu, doświadczaniu, przeżywaniu. Ich rezultaty stanowią bowiem dopiero „materiał” wyjściowy właściwego, racjonalnego poznania i uogólniania doświadczeń jednostkowych — „materiał” pałubiczny mieszczący się jednak w obrębie kultury jako ludzkiego „świata życia”. Można dodać, że sama Patuba jako tekst kultury — powieść, „quasi-powieść” lub proza wielogatunkowa - odwoływała się do biograficznego „materiału życia”, a zarazem stanowiła nowatorską konstrukcję prozatorską ${ }^{15}$.

\section{Pałubiczność a konstrukcja kulturowa}

Trzeba podkreślić, że obydwa ujęcia pałubiczności — i jako zapośredniczenie tego, co naturalne i kulturowe w człowieku, i jako to, co reprezentuje "naturę" w obrębie kultury - łączą się z ujmowaniem "pierwiastka konstrukcyjnego" i kulturowej konstrukcji, której wynikiem jest pewien kontekst kultury wraz z obowiązującymi w niej symbolizacjami, normami i wartościami. Można powiedzieć, że Karol Irzykowski — w znacznej mierze — utożsamia „pierwiastek konstrukcyjny" z elementami kultury i cywilizacji zachodniej, a nawet z kulturotwórczymi procesami modernizacyjnymi w obrębie społeczności europejskich. Jest to lepiej widoczne w jego późniejszych pracach dotyczących klerkizmu oraz literackich odmian formalizmu, między innymi w Walce o treść (Irzykowski 1976a), ale również w Patubie pojawiają się uwagi na temat awansu cywilizacyjnego bohaterów, wymagającego racjonalnych działań, a przede wszystkim — racjonalnego rozpoznania reguł społecznych i kulturowych wraz z hierarchią symboliczną.

Krytykowany wielokrotnie przez Irzykowskiego błąd poznawczy bohatera Patuby polegał na mylnym uznaniu konstruktu za to, co dane bezpośrednio w doświadczeniu (por. Budrecka 1981: XLVI). Równocześnie Irzykowski w swojej powieści przekonywał czytelnika o konieczności świadomego i racjonalnego powoływania konstruktów. Występował natomiast przeciw ich anachronicznemu utrwalaniu („formy gotowe” - por. Budrecka 1981: LVII)) wobec faktów wciąż odmieniającego się życia. Byłaby to zatem wyważona krytyka schematów i systemów, kierująca się przeciwko ich anachronicznym postaciom i równocześnie połączona z postulatem twórczego, innowacyjnego podejścia do schematu i systemu jako konstrukcji kulturowych (por. tekst System 'od - do', Irzykowski 1998-1999).

15 O nowatorstwie literackim Patuby pisali między innymi: Głowiński 1997, Werner 1965, Wyka 1968 (w szczególności teksty Wstęp do „Patuby” i „Patuba” a „Próchno”), Jauksz 2015. 
Należy przypomnieć, że Irzykowski odróżniał to, co kulturowe i to, co społeczne. Uważał kulturę za specyficznie ludzki „świat życia”, w którym dominuje "czyn intelektualny” — racjonalne poznanie (to, co duchowe) i działania symboliczne (związane z religią, ale też z komunikacją w ogóle). To, co kulturowe uważał zarazem za nacechowane gatunkowo, bowiem działania człowieka, w tym aktywność poznawcza, związane są z percepcyjnym i intelektualnym wyposażeniem człowieka, danym nam w porządku biologicznym, gatunkowym. Natomiast to, co społeczne Irzykowski rozpatrywał przede wszystkim jako działania wspólnotowe, związane między innymi z organizacją ludzkiej zbiorowości. Irzykowski ujmował kulturę — z inspiracji myślą Friedricha Hebbla, filozofią życia, w tym również filozofią Henri Bergsona — jako dynamiczny, twórczy proces. Rozpatrywał kulturę w kontekście przemian cywilizacyjnych oraz ekonomicznych i nie przeciwstawiał refleksji humanistycznej czy antropologicznej („nauk o człowieku") - technicznej wynalazczości. Dlatego wprowadził między innymi pojęcie "gospodarki duchowej” i ujmował kulturę w łączności z technicznym progresywizmem (analogia ustaleń Irzykowskiego z koncepcjami Georga Simmla i Maxa Webera). Trzeba podkreślić, że w koncepcjach Irzykowskiego brak jest wyraźnych rozróżnień na kulturę oraz cywilizację pojętą jako materialne i technologiczne instrumentarium. Według niego obydwie te dziedziny są tworzone przez człowieka dzięki twórczej inwencji i działaniom, a łączone są z indywidualnym rozwojem osobowym. Irzykowski jednak dokonał rozróżnienia na myślenie technologiczne i myślenie humanistyczne w swej polemice z Tadeuszem Żeleńskim-Boyem.

Zdaniem Irzykowskiego, wprowadzany przez człowieka „pierwiastek konstrukcyjny" jest związany z wolą, potrzebami i myśleniem życzeniowym (Irzykowski 1981: 344) ${ }^{16}$, ale ten teoretyczny konstrukt byłby „tylko przybliżeniem" (Irzykowski 1981: 360) ${ }^{17}$ do wiedzy o rzeczywistości złożonej i dynamicznej. Porządkowanie rzeczywistości w poznaniu może być także - wedle Irzykowskiego - jej „mistyfikowaniem”, a „celem wszystkich tych zabiegów, które można nazwać tworzeniem idealizacji rzeczywistości czy jej pojęciowych schematów, jest chęć nadania sensu zjawiskom, skomplikowanym w swej różnorodności, uporządkowania ich przez uproszczenie" (Budrecka 1981: XL). Ustalone, „konstrukcyjne” klasyfikacje i normy wciąż są bowiem konfrontowane z indywidualnym doświadczeniem, działaniem, praktyką (Irzykowski 1981: $385)^{18}$. Dlatego Irzykowski określa „pierwiastek konstrukcyjny” jako „wieżyczki

\footnotetext{
${ }^{16}$ Rozdział XVIII Zrobienie fazy.

17 Rozdział XIX Trio autora.

${ }^{18}$ Rozdział XX Patuba.
} 
nonsensu" (Irzykowski 1981:351) ${ }^{19}$ — jako to, co zarazem umożliwia i ogranicza poznanie, co porządkuje wiedzę, ale nie czyni jej pewną, zmuszając do konfrontacji z nowymi doświadczeniami. I to właśnie „pierwiastek konstrukcyjny odnosi w końcu nad Strumieńskim zwycięstwo" (Irzykowski 1981: 453, Uwagi do „Patuby”), a więc rozum i kultura zwyciężają nad naturą i fizjologią. Irzykowski ujmował to jako prymat "pierwiastka konstrukcyjnego” bez uwzględniania „pierwiastka pałubicznego". Równocześnie krytykował sposób myślenia, który autonomizował lub absolutyzował ów „pierwiastek konstrukcyjny”, prowadziłoby to bowiem do uznania wszystkich subiektywnych poglądów za równoprawne bez możliwości wskazania kryteriów ocen bądź też do narzucania pewnych norm przez jednostki o dużej sile oddziaływania. Dlatego niezbędne byłyby kryteria merytoryczne, a także przeciwstawienie modom intelektualnym — „tendencji” jako realizacji idei w różnych kulturowych wytworach.

Jak już wspomniałam, Irzykowski w Patubie pisał krytycznie o introspekcji jako temacie traktowanym powierzchownie (por. Irzykowski 1981: 114) ${ }^{20}$, poddanym pochopnie "pierwiastkowi konstrukcyjnemu” - poznawczym konstruktom kultury, które zapośredniczają wiedzę jednostki o sobie i mogą ograniczać jej samowiedzę. Zdaniem autora Patuby przedstawienie i mentalne, i kulturowe to sposoby opanowania realności „pałubicznej”, to ograniczanie jej do realności antropocentrycznej z pomocą „pierwiastka konstrukcyjnego”. Trzeba podkreślić, że dotyczyło to również konstrukcji językowych, ponieważ treści świadomości i treści nieświadome byłyby językowo „konstruowane”, interpretowane i rozumiane. Wedle Irzykowskiego samopoznanie i samowiedza uczestników kultury jest również determinowana przez „pierwiastek pałubiczny”, ponieważ tworzą oni konstrukcje, plany, idealizacje, którym jednak wymyka się pałubiczna „obfitość życia” (Irzykowski 1981: 351)21, tak jak dotychczasowej koncepcji powieści wymykają się treści Patuby jako utworu prozatorskiego, poświadczającego „pałubiczny” autentyzm przeżyć bohatera.

\section{Akulturacja jako modernizacja?}

Można powiedzieć, że swoimi przemyśleniami na temat pałubiczności i kulturowej konstrukcji Karol Irzykowski wpisywał się w ówczesne dyskusje dotyczące specyfiki ludzkich wytworów $\mathrm{w}$ zestawieniu $\mathrm{z}$ naturą, ale również $\mathrm{w}$ debaty na temat wpływów i kręgów kulturowych. To właśnie z okresu pracy nad Patuba i nad komentarzami do książki pochodzą badania niemieckich dyfuzjonistów

\footnotetext{
19 Rozdział XIX Trio autora.

${ }^{20}$ Rozdział VII Nowa próba w gtą .

21 Rozdział XIX Trio autora.
} 
i wiedeńskiej szkoły dyfuzjonizmu, koncepcje Kulturkreis i „wędrówki elementów kulturowych" (Friedrich Ratzel, Bernhard Ankermann, Leo Viktor Frobenius, Fritz Graebner, Wilhelm Schmidt). W tekście zaproponowałam dwa ujęcia pałubiczności. Pierwsze z nich, najbardziej rozpowszechnione, pozwala pojmować „pierwiastek pałubiczny” jako przechodni — jako to, co zapośrednicza relację między naturą i kulturą w samookreśleniu się człowieka, w antropologicznym samodefiniowaniu jednostki, zarówno wobec świata przyrodniczego, jak i wobec innych ludzi, w obrębie danego, zastanego kontekstu kulturowego. Tak pojęta pałubiczność umożliwia wejście jednostki w świat społeczny i kulturowy - kulturową inkluzję w rozpoznaną „rzeczywistość”, pojmowaną jako obowiązujący zbiór znaków, znaczeń i norm, a de facto konstruowaną i relatywną. Tak rozumiana pałubiczność umożliwia zatem enkulturację jednostki, wprowadzenie w obręb kultury, w jej kontekst uznawany za obowiązujący i nie podlegający relatywizacji.

Jednak Irzykowski prezentuje w Patubie różne konteksty kulturowe, ponieważ przywołuje rozmaite „światy społeczne”, ukazuje skomplikowane relacje między przedstawicielami różnych grup społecznych, niejednolitych nawet w przypadku szlachty czy drobnego mieszczaństwa Galicji (por. Irzykowski 1981: 47-52) ${ }^{22}$. Jak wiadomo, Galicja była wielokulturowym i wielonarodowym światem, spajanym między innymi dzięki przywiązaniu jednostek i grup do instytucji państwowych oraz dzięki systemowi edukacji. Irzykowski krytykował obyczaje szlachty galicyjskiej, jej tradycjonalizm i społeczną pasywność. Pałubiczność, pojmowana jako prymarny związek człowieka $\mathrm{z}$ naturą, jawi się w takim kontekście jako bezpośredniość, która przywraca jednostce jej prymarne ludzkie cechy, pozwala dostrzec lekceważone atrybuty - aktywizm i sprawczość, poczucie „bezpośredniego" związku ze światem, ale także z własną cielesnością i umysłowością. W tym drugim rozumieniu pałubiczności radykalizuje się koncepcja konstrukcji, która wiąże się — co oczywiste w przypadku pokantowskich (Johann G. Fichte, Friedrich W.J. Schelling - por. Schelling 1979: 23) i neokantowskich koncepcji konstrukcji — z tezami obiektywizującymi Rozum i subiektywną, jednostkową racjonalność (z tezami mającymi swe źródła w filozofii starożytnej Grecji). Mówiąc inaczej, relacja między pałubą i konstrukcją zachodziłaby w obrębie kultury, to znaczy w sferze aktywności i wytworów człowieka. Właśnie takie racjonalne, cywilizacyjne „oswajanie” obcości spotyka Piotra Strumieńskiego w kontaktach z rodziną mającą arystokratyczne pretensje, która postrzega go jako „dzikiego” (por. Irzykowski 1981: 112) ${ }^{23}$ lub nazbyt pospolitego, mimo jego przynależności do szlachty i znajomości reguł symbolicznych: „Wygrzebano

\footnotetext{
${ }^{22}$ Rozdział II Pierwsze zatamanie linii.

${ }^{23}$ Rozdział VI Ola.
} 
różne rzeczy z przeszłości rodziców Piotra, poruszono kwestię jego 'chamstwa' ” (Irzykowski 1981: 53) ${ }^{24}$.

Trzeba dodać, że „pierwiastek konstrukcyjny” łączony jest przez Irzykowskiego z obiektywnie pojmowanym Rozumem, ale — co więcej — z modernizacyjnymi procesami zachodzącymi w obrębie tradycyjnych społeczności, z "cywilizacją" odmieniającą to, co materialne, jak i to, co duchowe, ale w ramach zachowanej hierarchii społecznej. W tym przypadku trudno jest mówić o enkulturacji, tym bardziej, że to, co „pałubiczne” dysponuje własnymi sposobami porozumiewania się, odnoszenia do świata (na przykład z pomocą gestów) i dyspozycjami samookreślenia się wobec innych bytów w świecie. Pałubiczność posiada zatem pewne kody komunikacji ze światem, tyle, że trudno zrozumiałe dla przedstawicieli innych grup społecznych. W tym przypadku należałoby mówić raczej o akulturacji, ponieważ to właśnie akulturacja dotyczy włączenia w obręb kultury, uważanej za wyższą w symbolicznej hierarchii społecznej, to znaczy kultury związanej z modernizacyjnymi procesami obiektywizacji i racjonalizacji. Kategoria akulturacji dotyczyłaby w przypadku Patuby nie tylko reprezentantów „pałubicznej kultury”, pomniejszej, ludowej, nieskomplikowanej symbolicznie, ale przede wszystkim szlachty galicyjskiej, broniącej się przed procesami modernizacji, a więc przed konsekwentnym poddaniem się „pierwiastkowi konstrukcyjnemu” wraz z jego „cywilizacyjnymi” konsekwencjami: obiektywizującą racjonalizacją, policzalnością i przewidywalnością, która wykracza poza reprodukcję wzorców tradycyjnej kultury. Jednak, jak zauważał Irzykowski, modernizacyjne zmiany postępowały wbrew przywiązaniu do tradycji:

Upokorzenia z czasów młodzieńczych, pamięć własnego niedostatku wśród wyższych potrzeb kulturalnych poznawanych wówczas nauczyły go [Strumieńskiego] cenić potęgę pieniędzy jako wartości materialnych, dających się łatwo zamienić na intelektualne i uczuciowe, i nakazały mu strzec czujnie a z bezwzględnym egoizmem tych tak szczęśliwie nabytych skarbów. (Irzykowski 1981: 53-54) ${ }^{25}$

Oba wspomniane ujęcia pałubiczności i jej relacji z „pierwiastkiem konstrukcyjnym” dają się łatwo odnaleźć w Patubie, ale trudno jest je ze sobą pogodzić i byłoby to — paradoksalnie — zgodne z postulatem „komplikacjonizmu” Irzy-

${ }^{24}$ Rozdział III Intruz. Na przywiązanie do tradycji i jej hierarchii symbolicznej, a zarazem na równoczesne podważanie tradycyjnych reguł wskazują inne słowa Irzykowskiego: „Lecz on, niestety, pochował ją w grobie familijnym, tak jak przystało na 'pana' Strumieńskiego, jak należało uczynić, żeby sąsiedzi, przyszedłszy na pogrzeb, nie szeptali sobie do ucha o jego dziwactwach (punkt wstydliwy); w grobie familijnym, w którym oprócz starego Strumieńskiego i Roberta żaden umarły nic go nie obchodził, a w którym Angelika była przecież intruzem" — Irzykowski 1981: 206-207, rozdział XI pierwiastek patubiczny.

${ }^{25}$ Rozdział III Intruz. 
kowskiego. Pierwsze z tych ujęć ma odniesienie retrospektywne i zarazem wykracza poza proste rozróżnienie: natura — kultura, które odnajdujemy przed filozofią życia Diltheya i Nietzschego, przed poszukiwaniami dyfuzjonistów i funkcjonalistów. Z kolei drugie ujęcie pałubiczności jest prospektywne, a ma inspiracje między innymi w filozofii Henri Bergsona i w psychoanalizie Zygmunta Freuda, których koncepcjom Irzykowski poświęcił wiele uwagi. Zapowiada ono avant la lettre dwudziestowieczne studia nad korporalnością, podmiotem receptywnym i pasywnym, płcią kulturową, ale także studia postkolonialne. Jak wskazuje Arjun Appadurai, akulturacja do życia w społeczeństwach zmodernizowanych stała się celem przedstawicieli wielu kultur „kolonizowanych”, które ostatecznie same zaproponowały wzorce kultury, przejmowane przez dysponentów modernizacji (Appadurai 2005: 133-168) ${ }^{26}$. Teza o akulturacji utożsamianej z modernizacją, obecna implicite w Patubie, była potem rozwijana przez Irzykowskiego — klerka i racjonalistę. Trzeba przypomnieć, że była ona popularna w dwudziestoleciu międzywojennym, nie tylko w politykach kolonialnych, a i współcześnie jest powtarzana i uważana za aktualną.

\section{BIBLIOGRAFIA}

Appadurai Arjun. 2005. Nowoczesność bez granic. Kulturowe wymiary globalizacji. Przeł. Zbigniew Pucek. Kraków: Universitas. [Modernity at Large. Cultural Dimensions of Globalization].

Budrecka Aleksandra. 1981. Wstęp. W: Irzykowski Karol. Patuba. Sny Marii Dunin. Oprac. Aleksandra Budrecka. Wrocław-Warszawa-Kraków: Zakład Narodowy im. Ossolińskich - Wydawnictwo. S. III-LXXXVIII.

Głowiński Michał. 1997. Powieść mtodopolska. Studium z poetyki historycznej. Kraków: Universitas.

Irzykowski Karol. 1976. Stoń wśród porcelany. Studia nad nowsza myśla literacka w Polsce. Pisma. Część 3. Red. Andrzej Lam. Kraków: Wydawnictwo Literackie.

Irzykowski Karol. 1976a. Walka o treść. Studia z literackiej teorii poznania. 1. Zdobnictwo w poezji. 2. Treść i forma. Pisma. Część 2. Red. Andrzej Lam. Kraków: Wydawnictwo Literackie.

Irzykowski Karol. 1981. Patuba. Sny Marii Dunin. Oprac. Aleksandra Budrecka. Wrocław: Zakład Narodowy im. Ossolińskich. Patuba (Studium biograficzne). S. 43-396. Uwagi do „Patuby”. S. 397-454.

Irzykowski Karol. 1998-1999. Pisma rozproszone. Tom III. Pisma. Częśc 8. Red. Andrzej Lam. Kraków: Wydawnictwo Literackie. System 'od - do'. S. 322-327.

${ }^{26}$ Rozdział Gra z nowoczesnością: dekolonizacja hinduskiego krykieta. 
Jauksz Marcin. 2015. Krytyka dziewiętnastowiecznego rozumu. Źródta i konteksty „Patuby” Karola Irzykowskiego. Kraków: TAiWPN Universitas.

Schelling Friedrich W.J. 1979. System idealizmu transcendentalnego. Przeł. Krystyna Krzemieniowa. Warszawa: PWN.

Werner Andrzej. 1965. Cztowiek, literatura i konwencja. Refleksja teoretycznoliteracka w „Patubie” Karola Irzykowskiego. W: Z problemów literatury polskiej XX wieku. Tom I: Mtoda Polska. Red. Jerzy Kwiatkowski, Zbigniew Żabicki. Warszawa: PIW. S. 327-369.

Wyka Kazimierz. 1968. Modernizm polski. Kraków: Wydawnictwo Literackie.

Maria Gotębiewska

\title{
PAŁUBIC ELEMENT, CONSTRUCTION AND ACCULTURATION IN "PAŁUBA" BY KAROL IRZYKOWSKI
}

\author{
(summary)
}

The aim of the text is to discuss Karol Irzykowski's concepts of "pałuba" and construction, which he proposed in Patuba (1903), where he characterises a "constructional element" appealing to the theses of empirical criticism of Richard Avenarius and Ernst Mach. However, the question of the construction, understood first from the epistemological and psychological point of view, was present in the theses of Kant, Fichte and Schelling, and it became popularised thanks to neo-Kantianism and empirical criticism. The theses related to the construction were intensively discussed during the creation of Patuba and Irzykowski's subsequent works, in which the issue of construction also appears, considered as a cognitive schema, as the formal element confronted with the content, as the constructional aspect of the verbal and visual (film) communication. His later works concern the cultural construction which is also a formal construction, and they come into being at the same time that Cassirer's books on the symbolic forms of culture were published. However, the question of construction is best presented in Patuba, described with the phrase "constructional element", which was opposed to a "pałuba" ("pałubic element"). Confronting the terms "pałuba", i.e. natural, direct, presented to the human being, and "construction", i.e. the world created by human beings, specific for us, Irzykowski defines human existence, he shows the regularities of human acts, cognition and feeling. At the same time, he captures the "natural" aspect of culture with the use of the term "pałuba". It is that coexistence of the naturalness and the specifically human products within the world of culture — in the world which annexes the "natural", bestows the senses and meanings on "pałuba" — that makes an "enculturation" possible, i.e. an introduction of the "wild" man into culture, teaching and adaptating to life in 
the cultural world, full of human senses and meanings. The text discusses the category of the "constructional element" and presents Irzykowski's thoughts on the background of the hitherto existing concepts of construction, as well as in the context of his own anthropological, epistemological and cultural theses.

\section{KEYWORDS}

pałuba; nature; construction; enculturation; acculturation 


\section{KONTEKSTY INKULTURACYJNE W „RĘKODZIELE FABRYKI SUKIENNEJ..." WACŁAWA SIERAKOWSKIEGO}

\section{SŁOWA KLUCZOWE}

Wactaw Sierakowski; Rękodzieto Fabryki Sukienney...; akulturacja; praca; miasta w XVIII wieku

Wiek osiemnasty to w Polsce okres głębokich przemian kulturowych i społecznych $^{1}$, charakterystycznych dla rozkładu feudalizmu. Były one związane z rozwojem gospodarczym, a w konsekwencji - ze wzrostem liczby mieszkańców, zwłaszcza w miastach, układaniem stosunków międzywyznaniowych i międzykulturowych. Ponadto dokonywało się wówczas przekształcanie struktury społeczno-zawodowej oraz formowanie nowej struktury kapitalistyczno-klasowej. Proces akulturacji przebiegał zatem w dobie oświecenia w sposób zarazem nasilony, jak i wielotorowy. Wzmożone bezpośrednie konfrontacje z odmiennymi systemami wartości, reprezentowanymi przez cudzoziemców i innowierców, w - dotychczas dość homogenicznym kulturowo i wyznaniowo — kraju wywołały szereg dyskusji i przemian, ale zarazem stawały się pożywką dla stereotypowego myślenia.

U schyłku osiemnastego wieku przybywało ludności niemieszczącej się w tradycyjnym schemacie społeczeństwa, w którym obok hierarchizującego „urodzenia”, pojawiło się nowe kryterium dyferencjacyjne — majątkowe. Coraz

Marta Szymor-Rólczak — dr, Pracownia Edytorstwa, Instytut Filologii Polskiej i Logopedii, Wydział Filologiczny, Uniwersytet Łódzki, ul. Pomorska 131/133, 90-236 Łódź; e-mail: marta. rolczak@uni.lodz.pl

1 Informacje historyczne na temat struktury ludności w Warszawie XVIII wieku podaję za: Chyra-Rolicz 1986: 71, 73-75; Zahorski 1984: 237-238, 289-294; w Krakowie: Bieniarzówna, Małecki 1984, t. 2: 561 i nn.; Wawel 1977: 55 i nn.; szerzej na temat społecznej struktury miasta Krakowa patrz: Bieniarzówna 1969; Pachoński 1956. 
liczniejszy stawał się margines społeczny — heterogeniczna grupa ludzi, najczęściej napływowych, poszukujących jakiegokolwiek zajęcia, której gros stanowili zbiegowie, przestępcy, włóczędzy oraz „ubóstwo żebrzące”. Zwano ich „ludźmi luźnymi” z uwagi na ich kondycję gospodarczą i społeczną: byli to przybysze bez przeszłości i przyszłości, niepotrafiący zakorzenić się w nowym środowisku, bezdomni tułacze.

Zarazem jednak w końcu osiemnastego wieku wśród mieszczaństwa rodziły się nowe, budujące odrębność, wspólnoty interesów, owocujące ekonomiczno-gospodarczymi projektami promieniującymi na struktury społeczne miast. Ale rozwój handlu i rzemiosła nie był możliwy bez dużej liczby rąk do pracy. Tę zaś próbowano pozyskać wśród „ludzi luźnych”. Podejmowano próby ich masowego zatrudnienia jako najemnej siły roboczej, tak zwanego proletariatu. Ze względu na wysoki stopień demoralizacji rekrutowanych, stosowano szereg działań służących ich produktywizacji, z poprzedzaną obławami pracą przymusową na czele (patrz szerzej: Zahorski 1984: 289). Prowadzono także działalność edukacyjną i resocjalizacyjną, której dalekosiężnym celem była unifikacja i inkulturacja tej grupy społecznej, po uprzednim przywróceniu jej moralnego kręgosłupa.

Zarysowana powyżej sytuacja historyczno-gospodarczo-demograficzna skłoniła kanonika Wacława Sierakowskiego (1741-1806) ${ }^{3}$ do założenia na krakowskim Kazimierzu drukarni płócien i magla, a w 1786 roku manufaktury włókienniczej ${ }^{4}$

2 Według relacji F. Lichockiego, przed III rozbiorem liczba żebraków na terenie miasta Krakowa, liczącego sobie wówczas niespełna 9500 osób, utrzymywała się na poziomie około 500 osób (Lichocki, Naruszewicz, llner, Kleszczowa 1979: 46).

3 Sierakowski Wacław h. Ogończyk (ur. 1741 r. w Bogusławicach koło Koła, zm. 1806 r. w Krakowie), kanonik krakowski i sandomierski, filantrop, animator życia muzycznego — założyciel prywatnej szkoły muzyki; pisarz, tłumacz i wydawca, m.in. dzieł i podręczników poświęconych muzyce i edukacji muzycznej (Sztuka muzyki dla mtodzieży krajowej, t. 1-3, 1795-96), grze na fortepianie (Krótko zebrana szkota fortepianu dla zaczynających się uczyć, z najlepszych autorów muzyki wyjęta, [b.m. i r.w.]), architekturze (Architektura cywilna dla mtodzieży narodowej, cz. 1-2, Kraków 1796-97), rolnictwu i sztuce komponowania krajobrazu (Postać ogrodów, która do dwóch zmystów, smaku w owocach i powonienia w kwiatach szczególniej ściaga się, cz. 1-2, Kraków 1798), technice (Silnie, czyli oszczędzenie zdrowia pracujących okoto ciężarów, Kraków 1799; przeróbka z dzieła włoskiego N. Zabaglia), sztuce składania wierszy (Igraszki uczonego dowcipu, czyli rozmaitość gustu tworzenia wierszów, 1800) oraz publikacji religijno-moralizatorskich. (Informacje bioi bibliograficzne opracowano na podstawie: Aleksandrowska 1996-1997; Pachoński 1956; Snopek 1992: 76, 79, 103, 105, 121-122, 134, 141-142).

4 Manufaktura była formą produkcji przemysłowej, opartą na podziale pracy i technice ręcznej. Pierwsze manufaktury włókiennicze powstały w XIII-XIV w. we Flandrii (Gandawa, Brugia, Ypres) i we Włoszech (głównie Siena, Florencja); w XV w. — w południowych Niemczech, we Francji i Anglii. W Polsce forpoczty manufaktur powstały na przełomie XVI/XVII w. - m.in. kuźnice żelaza (Małopolska), zakłady metalowe (Gdańsk), zakłady hutnicze (Bobrza, Panki, Łaziec, Samsonów, Wschowa), wełniane S. Koniecpolskiego (Brody). Druga połowa XVIII w. to okres rozkwitu zwłaszcza manufaktur magnackich, królewskich i mieszczańskich, m.in.: kompleks 
na Stradomiu5 , działającej do 1791 roku. Fabryka powstała w budynku dawnego cuchthauzu $^{6}$, czyli domu poprawczego, mieszczącego się przy ulicy Szpitalnej. Funkcję głównego inżyniera oraz dyrektora technicznego, nadzorującego proces technologiczny, powierzył Sierakowski majstrowi Świerczkowskiemu, sam zaś podjął starania o zdobycie nakładów finansowych niezbędnych do uruchomienia fabryki. Zaowocowały one utworzeniem 30 stycznia 1788 roku stowarzyszenia 77 przedsiębiorców różnych specjalności, którzy zgodzili się finansować manufakturę. Pracowników rekrutował Sierakowski głównie wśród żebraków i sierot, będąc głęboko przekonanym o resocjalizacyjnym charakterze ich zatrudnienia. W fabryce produkowano sukno na potrzeby armii. Jednak nawet stałe zamówienia od tak ważnego odbiorcy nie uchroniły zakładu przed upadkiem, który nastąpił w 1792 roku wskutek rozbieżnych interesów administratorów i niefachowego prowadzenia produkcji ${ }^{7}$.

W związku z działalnością manufaktury, krakowski kanonik napisał i wydał własnym sumptem filantropijne Uwiadomienie of funduszu dla żebraków i fabryce sukiennej (Kraków 1789) oraz składające się z trzech części Rękodzieto fabryki sukiennej, które w Krakowie 1786 dla wielu pożytków i zatrudnienia ubogich jest ustanowione (Kraków 1797). Do dziś publikacja ta jest wysoko oceniana przez badaczy i praktyków włókiennictwa jako merytorycznie wartościowe kompendium wiedzy na temat technologii ostatnich lat ręcznego przędzenia w Polsce (Łuczak, Przybył 2004: 15-20).

W części pierwszej Rękodzieta fabryki sukiennej... autor ukazał w sposób wieloaspektowy przyczyny ${ }^{8}$, cele oraz skutki założenia manufaktury sukiennej

A. Tyzenhauza (Horodnica, Łosośna), fabryka sukien Elżbiety Sapieżyny z Branickich w Kodniu (patrz: Czeppe on-line, dostęp: 12.02.2017), manufaktury tkackie w Brodach, Buczaczu, Łowiczu, Nieświeżu, Skierniewicach, Słucku i Warszawie, szklane w Urzeczu, Nalibokach, farfurnie w Belwederze, Korcu i Telechanach. Większość manufaktur w Rzeczypospolitej upadła w końcu XVIII w., zaś te zakładane w 1. połowie XIX w. w większości przekształciły się w fabryki (Kula 1956, passim).

5 Fabrykę płócien i sukna oraz aptekę dla ubogich (1787) ufundował W. Sierakowski również w Sandomierzu.

${ }^{6}$ Pierwsze w Europie próby resocjalizacji poprzez pracę przymusową podjęto w początkach XVIII wieku we Włoszech, gdzie zakładano domus correctionis. W Polsce przyjęła się niemiecka nazwa domów poprawczych - cuhthaus. Patrz szerzej: Rożek, Kracik 2010; zwłaszcza rozdział: Przymus pracy. Dom poprawy i manufaktura żebracza.

7 Informacje na temat organizacji fabryki i jej losów podaję za: Dembowski 1791: 57-59, 84-87; Łuczak, Przybył 2007: 31-34; Łuczak, Przybył 2010: 21-23.

8 Diagnozy Sierakowskiego charakteryzują się dużą wnikliwością, ale i szeroką perspektywą, dotykają wielu problemów: „[...] szkody przypomnę: w Kraju gospodarstwo nikczemne, włościan ubogi, młodzież rozwiązła, czeladź rozpiła, Szlachta zbytkuiąca, Rękodzieła nie znane, Sztuki piękne zaniedbane, Szkoły zubożone, Rząd opuszczony, handel zarzucony, Obywatel wszelki zakłócony, Miasta podupadłe, a Saceros ut Populus etc. nie także iest u nas?" (Sierakowski 1797: I, 47; dalej lokalizuję: część cyfrą rzymską i stronicę — arabska). 
w Polsce. Część druga stanowi rejestr uwag natury organizacyjnej, część trzecia zaś poświęcona została technologii włókienniczej.

W Rękodziele fabryki sukiennej... Sierakowski zawarł wiedzę na temat włókienniczego rzemiosła, uzyskaną w praktyce w ciągu dwunastu lat, jakie poświęcił na budowanie i rozwój manufaktury9. Dzieło ukazało się drukiem „pracą i kosztem autora” w 1797 roku, a zatem pięć lat po zamknięciu fabryki. Czasowa perspektywa skłoniła Sierakowskiego do sformułowania zawoalowanego rozliczenia niepowodzeń, a przede wszystkim zwerbalizowania konieczności wyciągnięcia wniosków na przyszłość. Taką wymowę ma skierowana $D o$ Czytelnika przedmowa do drugiej części dzieła, która „krótkie opisanie historyi podaie", rozpoczynająca się słowami:

W przeciągu Dzieła tego byłoby wprawdzie do rzeczy przytoczyć w szczególności historyą rozmaitych zdarzeń i wypadków, których to w czasie zakładania i utrzymywania Fabryki [...] w różnym sposobie doznawałem, atoli nie chcę ogłaszać tego, co już minęło, ale raczey w postępowaniu do dalszego przedsięwzięcia zdało mi się krótkie przyłączyć opisanie w powszechności historii, która nauczając jak [...] doskonałości i niedoskonałości dochodzić, z różnych odmian, wynalazków i doświadczeń pożytkować [...] (II, Do Czytelnika [nlb.])

Wątki inkulturacyjne w Rękodziele fabryki sukiennej... związane są z etosem pracy. Zdominowały one pierwszą część dzieła, zwłaszcza zaś jej trzeci rozdział, którego kolejne paragrafy stanowią perswazyjny, zretoryzowany wykaz "pożytków z fabryki wynikających”. Manufaktura sukiennicza jest: „dobroczynna”, „dogodna”, „próżniactwa nieprzyjaciółką i wykorzenieniem”, „cnoty przyczyną”, „kołyską bogactw”, „duszą handlu i społeczeństw ludzi”, „miłości związkiem”, „rządu znakomitą zaletą”, „gospodarstwa wszelkiego pomnożeniem”, „prawdziwie rzetelnym skarbem” i „ludu powszechnym dobrem”. Sierakowski, pisząc o pożytkach płynących z założenia fabryki, stworzył zarazem kontekstowy katalog walorów pracy in genere. Jego dzieło wpisuje się zatem w nurt problematyki stanowiącej przedmiot zainteresowania wielu dyscyplin naukowych, takich jak: ekonomia, filozofia, fizjologia, fizyka, pedagogika, prakseologia, psychologia czy socjologia. Efektem badań każdej z nich jest odrębna definicja pracy (patrz m.in.: Kotarbiński 1965: 88).

Choć Sierakowski nie zdefiniował wprost terminu "praca”, to w jego wywodzie dostrzegalne są liczne odwołania do pokrewnych pojęć i kategorii, takich jak: potrzeby człowieka, będące jego siłą napędową oraz związane z nimi typy

9 „Fabryki zatem Sukienney, która od lat 12. była zabawą moją, wyjawię tu choć z większa przymioty [...]" (I, 5). 
motywacji; a nade wszystko oddziaływanie pracy na jakość życia, opisane za pomocą funkcji, jakie praca pełni.

Współcześnie w socjologii potrzebę definiuje się jako „poczucie braku czegoś, co jest odczuwane przez jednostkę jako konieczny, a przynajmniej pożądany element jej życia lub samorealizacji” (Olechnicki 1997: 160) i wydziela się — za Abrahamem Haroldem Maslowem - dwa typy potrzeb: podstawowe (zwane też potrzebami niedostatku) oraz poznawcze. Do pierwszego typu należą potrzeby: fizjologiczne (np. zaspokojenie głodu, pragnienia, ochrony przed zimnem), bezpieczeństwa (np. zniwelowanie ryzyka utraty środków do życia), przynależności i miłości (np. zdobycie przyjaźni, uznania, ludzkiej życzliwości, posiadanie rodziny), szacunku i uznania (np. akceptacja i pochwała działań), samorealizacji/samourzeczywistnienia (polegająca na stawaniu się tym, kim chciałoby się widzieć, doskonaleniu roli społecznej). Do typu drugiego zaliczamy zaś potrzeby: wiedzy i rozumienia (polega na systematyzowaniu, analizowaniu, konstruowaniu lub poszukiwaniu systemów wartości) oraz estetyczne (związane z wyrabianiem gustu, doznaniami estetycznymi) (patrz: Maslow 1964: passim).

Argumentacja Sierakowskiego, dotycząca pożytków założenia fabryki sukiennej i podjęcia pracy w niej, odwołuje się pośrednio do wszystkich wymienionych powyżej potrzeb jednostki ludzkiej. Fabryka, a w domyśle praca jako taka, pozwala człowiekowi zaspokoić potrzeby fizjologiczne — osłonić nagość, która jest tematem tabu dla człowieka cywilizowanego, zaspokoić głód, ochronić się przed zimnem:

Wstyd Człowiekowi rozumnemu tak iest wrodzony [...] iż gdyby nie był odziany, znaiąc nagość swoią nie śmiałby wniść między podobnych sobie, nabywać rzeczy koniecznie iemu potrzebnych do utrzymywania śmiertelnego życia (I, 35)

[...] prócz okrycia nagości naszey, chroni od zimna, ciepła dodaie, zdrowie konserwuie, czyni rozmaite i nieprzeliczone wygody i ozdoby $(I, 8)$

I tak widzisz chleb na niwach roskosznie okrytych, ktoż go ie w kłosie? O iak to wiele i wielu gatunków dowcipu ludzkiego doświadczeń potrzeba, nim się w bochenek do pożywania wypiecze! (I, 30)

Praca zapewnia także poczucie bezpieczeństwa, stabilności uzyskiwania dochodów niezbędnych do utrzymania siebie i najbliższych, co szczególnie istotne jest dla najuboższych, którym: „daie ciągle sposób utrzymywania życia przystoynego" (I, 11).

Silną motywacją do podjęcia pracy jest, mająca kilka oblicz, wewnętrzna potrzeba przynależności i miłości. Zaś zaspokajaniu tej potrzeby towarzyszy koncentrowanie się na zyskaniu szacunku i uznania, rozumianego jako wyrażona 
pochwałą akceptacja ze strony rodziny i grupy społecznej, której człowiek pracujący czuje się członkiem.

Sierakowski wielokrotnie wspomina o konieczności wdrażania do pracy od jak najmłodszych lat, co zapobiegać miałoby deprawacji młodzieży i wzmacniałoby więzi rodzinne pomiędzy rodzicami i dziećmi:

na ubogich Rodziców dobroczynna Fabryka, iż dzieci rozpustne do pracy zaprawia (I, 10)

[...] Rodzice dzieci rozwiozłemi czynią, niechże je od naymłodszego wieku do roboty oddaią, wdzięcznieyszemi ich dla siebie w dalszym wieku doznaią, zamiast co teraz na nich utyskują powszechnie. (I, 63)

Nadto praca wykonywana wspólnie, z radością i śpiewem na ustach pozwala na zżycie się ze społecznością środowiska. Oddalając groźbę zarówno waśni międzyludzkich i nieakceptowalnych zachowań, jak i zawodowej nieuczciwości, ułatwia pozyskanie przyjaźni, ludzkiej życzliwości oraz umożliwia osiągnięcie stabilnej pozycji na drabinie społecznej:

A to tak miłe, iż życie na śpiewaniu wdzięcznie i wesoło przechodzi, bo spółem robiącym [...] słów i rzeczy w reszcie materii do swarów nie staie, tylko do śpiewania na Chory Pieśni pobożnych, maią naywiększą sposobność. (I, 41)

Taki był zwyczay dawnych naszych Oyców Polaków, kiedy Sukiennice Krakowskie Kazimierskie nie próżnowały, a kiedy na woynie maszerując ich Woyska: Zawitay Ranna Jutrzenko i Pieśń S. Woyciecha między innemi razem śpiewali [...]. Toż czyniono po domach, to przy warsztatach, toć nie dziw, iż były szczęśliwsze czasy nad nasze. (I, 41-42)

Taki życia spólnego nad robotą sposób, iest prawdziwym miłości Chrześcijańskiej związkiem, bo w śpiewaniu pobożnych Pieśni uczy się cnoty, czas wesoło spada, robota śpieszniey idzie, BOG którego brzmi Chwała prace pomyślnym końcem uwiecznia. Mniey czasu do kłótni, do swarów, do swawoli i do niepoczciwości. (I, 42-43)

Wiele uwag autora odnosi się do potrzeby samorealizacji, zwanej też potrzebą samourzeczywistnienia, a zatem stawania się tym, kim człowiek chce być i doskonalenia jego społecznej roli. W przedmowie Do Czytelnika w części pierwszej, prezentując cel i genezę powstania opracowania, Sierakowski stwierdza, że:

Nic życia ludzkiego równie nie wzmacnia, jak uczciwa i ustawiczna praca, tudzież Industrya pilna. Lenistwem tępią się umysły, ciała trętwieją i do chorób sposobnieyszemi się staią. Od tego wszystkiego broni ćwiczenie. (I, Do Czytelnika [nlb.]) 
Dzięki podjęciu zajęcia zarobkowego możliwe jest kreowanie własnego życia, praca daje bowiem do tego niezbędne narzędzia: „dowcip zaostrza, siły zastala, czerstwości pomaga” (I, 13), pozwala na „pędzeni[e] życia swojego zabawnie, wesoto i pożytecznie" (I, Do Czytelnika [nlb.]). Praca, rozumiana przez Sierakowskiego jako przeciwieństwo rozpowszechnionego w Polsce próżniactwa, będącego, zdaniem autora, przyczyną wielu klęsk kraju, rozbudza intelektualnie, dając asumpt do dalszego rozwoju osobistego:

[...] Młodzieniec poczciwego serca tak się usposobi i zakocha w pracy, iż wszelkiey usilności nie tylko w industyi przemysłu zażywać będzie na pozyskanie Talentów Sztuk i Nauk. (I, Do Czytelnika [nlb.])

Zaspokoiwszy potrzeby pierwszego rzędu, człowiek pracujący zaczyna dążyć do dalszego doskonalenia się i poszerzania swej wiedzy, rozwija procesy analityczne, systematyzuje zdobytą wiedzę, usiłując odkryć nadrzędne prawa i zasady:

Jle zaś Ludzi potrzebuje Fabryka niżej się oznaczy: a to, do roboty, do rachunków, do straży, do dozoru, do handlu, do rządu, etc. do iakieyże zaś doskonałości zatrudniających się sobą nie doprowadza? Gdyż procz starania i prac powszechnych musi pilnować Wagi, co do włosa, Opisu co do sierci; Miary, co do calu; Rachunków co do denaru; Czasu co do momentu; Świadectwa co do Imienia; Wiary co do słowa; Kredytu co do poczciwości co do cienia niepoślakowanie; A zawsze wszystko z rozumem i racyą, Jakże wśrzód tak doskonalącego się w ustawiczney pracy i wydoskonalonego Ludu, nie ma bydź miłe pożycie? (I, 40-41)

Posiadłszy szczegółową wiedzę empiryczną, człowiek ewoluuje w kierunku myślenia teoretyzującego, czego dowodzi kierowany do czytelników wykład historyczny: „Naywięksi i naysławnieysi Ludzie mimo pracy wysokich Urzędów swoich, ręcznemi się zabawiali robotami." (I, Do Czytelnika [nlb.]).

Sierakowski wspomina także wielokrotnie o ludzkich motywacjach podjęcia pracy, różnicując je ze względu na osiągnięty status majątkowy: „Do niey [pracy] ubogiego przyciska niedostatek, bogatych sama fortuna” (I, 22). Autor objaśnia pozorny alogizm zawarty w powyższym sformułowaniu, kładąc nacisk na większą odpowiedzialność społeczną bogatszych reprezentantów społeczeństwa: „[bogatych] cięższe krzyże od których są wolni nędzarze, iako to: Prawa, kłótnie, spory, utrzymanie maiątku, punkt honoru, edukacya dzieci, Urzędów sprawowanie $\& c "(\mathrm{I}, 22)$.

Człowiek, który nie musi całej swej uwagi koncentrować na zaspokajaniu potrzeb podstawowych, zwraca uwagę na harmonijność funkcjonowania oraz estetyczne - w tym także higieniczne - walory swego otoczenia, wyrabia w sobie wyczucie piękna i gust: 
[Fabryka] i w materialnym gospodarstwie [...] ćwiczy, czyniąc Panów potrzebnemi ubogim, w dostarczaniu produktów, ubogich Panom wzajemnie w wyrabianiu tychże produktów, i gruntowe nawet gospodarstwo wspomaga, bo naciska dla zarobku przychowywać trzody, czynić rolą zyznieyszą, czystość koło nich zachowywać, i wszystkich innych Krajowych produktów konsumpcyją czyni [...] (I, 50-51; podkr. - M.S.R.)

Nawet wykonywanie prostej pracy fizycznej może stać się okazją do obcowania ze sztuką i pięknem, a tym samym wyrabiania zmysłu estetycznego. Jak podkreśla bowiem Sierakowski, rozwój fabryki sukiennej oznacza pozostawanie pod wpływem „innych Sztuk, Kunsztów, wszelkiego gatunku rzemieślniczych rąk, pomocy, Mechaniki, handlów, tysiącznych potrzeb [...]” (I, 12).

Duża cześć tez Sierakowskiego ukazuje oddziaływanie pracy na jakość życia. Wpływ ten można opisać za pomocą pięciu funkcji (Furmanek 2008: 57, 210), jakie praca pełni w życiu człowieka. Homo faber to człowiek świadomie kierujący swym życiem, praca zaś pozwala mu osiągnąć poszczególne fazy rozwoju. $\mathrm{Na}$ poziomie potrzeb podstawowych praca jest źródłem egzystencji człowieka i sposobem na kreowanie przez niego własnego życia, co autor Rękodzieła... wyraża explicite: „Ten iest nas śmiertelnych udział, ani inszemi Prawami i Monarchów Syny rodzą się, iak: Quisquis nascitur ad laborem nascitur. Do pracy, do pracy." (I, Do Czytelnika [nlb.]) bądź też konstruuje alegoryczną przypowieść:

Migdat najpierwszy z drzew kwitnie i swóy kwiat na niebespieczeństwo mrozu wystawia, chociaż nie rodzi owoców aż w głębokiey Jesieni, Morwowe zaś drzewo szczególnieysze bo lubo ostatnie [...] kwitnie, naypierw iednak swe wydaje owoce ${ }^{10}$. O iak większa część ludzi podobnieysza do pierwszego niż do drugiego z tych drzew gatunku; dla tego też kwiat młodocianego wieku swojego narażając nie dościgają wydawać cnotliwych owoców. (I, Do Czytelnika [nlb.])

Sierakowski udziela także wskazówek w zakresie kreowania dobowego rytmu życia osoby pracującej, które stanowią forpoczty zasad bezpieczeństwa i higieny pracy, zwłaszcza zaś właściwego odżywiania i odpoczynku:

Urządzić trzeba swoie roboty i prace rozumnie, wykonywać ie pilnie a co naywiększa statecznie, snu, jak pokarmu zażywać miernie, w tym bowiem przebrana miara, nie tylko iest nieprzystoyna, ale i zdrowiu szkodliwa. (I, Do Czytelnika [nlb.])

${ }^{10}$ Morwa biała kwitnie w maju, zaś owocuje już latem; migdałowiec pospolity w polskich warunkach klimatycznych kwitnie w marcu (zanim wypuści liście), owocuje zaś dopiero we wrześniu. W Biblii migdałowiec zwyczajny nazwany został „drzewem czuwającym”, co związane jest z tym, że w klimacie bliskowschodnim zakwita bardzo wcześnie (już w połowie lutego). W języku hebrajskim słowo określające migdałowca znaczy 'czuwać' lub 'strażnik' (Włodarczyk 2011). 
Drugą funkcją jaką pełni praca w życiu człowieka jest tworzenie podstaw moralnego rozwoju jednostki. Wykład krakowskiego kanonika przesycony został odwołaniami do moralnych i duchowych wartości. Praca jest w ujęciu Sierakowskiego tożsama z cnotą: „Praca więc i cnota są naszą iedyną robotą nie próżnowanie, albo roskoszy.” (I, Do Czytelnika [nlb.]); „Wszelka praca rodzi Cnotę, Cnota rodzi honor” (I, 27); „Prawdziwey się Cnoty i Honoru, nie inaczey tylko usilną pracą dorabiać potrzeba" (I, 28).

Obligatoryjność pracy stanowi konsekwencję grzechu pierworodnego, a zarazem formę jego odkupienia: „Próżniaków Fabryka nie cierpi, nie przyimnie, gdyż wszyscy Ludzie [...], nosząc na sobie Dekret wyroku Raju przeciw nim wypadłego po grzechu «W pocie czota twego będziesz pożywat chleba twojego» pracować koniecznie powinni.” (I, 15). Chorobą duszy i przyczyną cierpień, zarówno doczesnych, jak i wiekuistych, jest lenistwo: „Próżniak [jest] igrzyskiem czarta” (I, 15), „próżnowanie rodzi wszelkie nieprawości” (I, 16), a „Gdzie [...] próżnowaniem bawią się, tam [...] szczebiotania, obmowy, kłótnie, sfary zamnożone, do ubóstwa w czasie życia, do utraty zbawienia wiecznego po śmierci przywodzą" (I, 22-23). Sierakowski zapewnia, że praca jest jedyną drogą do osiągnięcia zbawienia: „Strzeż się próżnowania a wszystko złe wykorzenisz.” (I, 45) i zachęca do nieustannego wysiłku: „Niechże nas zawsze i bezprzestanku prac różność zatrudnia, albowiem stabieje bez przeciwnika cnota, $w$ ten czas się pozna iakiegoś umystu, gdy co możesz, cierpliwość okaze." (I, 23).

W wyniku pracy powstają materialne warunki realizacji i rozwoju człowieka. Funkcja ta koresponduje z pierwszą z podstawowych potrzeb człowieka. Sierakowski enumeruje liczne korzyści wynikające z pracy: „daie [...] sposób utrzymywania życia przystoynego" (I, 11), karmi, okrywa nagość, chroni od zimna, daje ciepło, czyni wygody, a jej wytwory zdobią otoczenie.

W tekście nie zabrakło także fragmentów, w których założyciel fabryki sukiennej dopomina się od władz stanowczych działań, mających na celu stworzenie dogodnych politycznych, społecznych i gospodarczych warunków do rozkwitu manufaktur w Polsce, wskazując zarazem na korzyści płynące z proponowanych reform: „Do Rządu należy, ażeby zbytki obciąwszy potrzebie służyła [...] wszystekby lud kraiowy miał przyzwoitą wygodę, a Kray bylby bogatszy przez handel, którego to Rękodzieto iest duszą." (I, 32).

Praca, głównie przez rozwój rozmaitych technologii, jest także sposobem na doskonalenie ludzkiego umysłu „przytępionego lenistwem”. Umysł ludzki bowiem bez „ćwiczenia” karleje i podobnie jak ciało staje się podatny na choroby. Dodajmy, że Sierakowski widział w swej fabryce potencjał stworzenia sprzyjających warunków do rozwoju jej pracowników: „[Fabryka] ludźmi zdatnemi czyni 
do wyższych Urzędów, formalnego gospodarstwa to iest Rachunków, kalkulacyi, handlu, przeyźrzenia, potrzebom zaradzenia [...]” (I, 50).

Najbardziej uwypuklona została w Rękodziele... kulturotwórcza i społeczna funkcja pracy jako działania wymagającego komunikacji oraz współpracy jednostek i grup. Sierakowski w różnych fragmentach swego dzieła akcentuje płynący z pracy pożytek dla ogółu. Wokół tego motywu buduje własną definicję „fabryki”: „Fabryka nic innego nie iest, iak zgromadzenie poczciwych oboiey płci Ludzi pracujących na wielorakie pożytki Powszechności” (II, 1). Także w licznych przestrogach i naukach kierowanych wprost do czytelnika, a zwłaszcza zaś do młodzieży, wzywa Sierakowski do ofiarnej i solidarnej pracy na rzecz publicznego pożytku:

Młodzieży [...] życzę i przepisuję, aby się rady [...] chwyciła: bydź powszechności użytecznymi, ani czekać, bydź szukanemi. (I, Do Czytelnika [nlb.])

Przeto ktokolwiek chce [Bogu] bydź miłym [...] publicznego niech szuka pożytku, niech dba o zbawienie bliźnich swoich. (I, Do Czytelnika [nlb.])

[...] zgoła iż nic nie mamy z siebie czegobyśmy [...] przez pracą bliźnich naszych nie posiadali, podobnież my dla bliźnich naszych iak najusilniej pracować jesteśmy winnemi. (I, Do Czytelnika [nlb.])

Sierakowski akcentuje znaczenie pracy jednostki w procesie inkulturacji. Praca jest dobrem wspólnym, kreującym rozkwit społeczeństwa, źródłem dobrobytu i siłą napędową rozwoju. Przede wszystkim jednak praca daje jednostce szansę na godne życie i chroni przed wykluczeniem, zarówno pod względem materialnym, jak i mentalnym. Nieproduktywne jednostki, zwane pogardliwie „marginesem”, poprzez aktywizację zawodową mają szansę stać się pełnoprawnymi członkami społeczeństwa.

Wizja nowego homo faber oraz postulaty zawarte w Rękodziele... stanowią forpoczty kiełkującej nowej kultury pracy — proletariackiej.

\section{BIBLIOGRAFIA}

Aleksandrowska Elżbieta. 1996-1997. [Hasło:] Sierakowski Wactaw h. Ogończyk. W: Internetowy Polski Słownik Biograficzny (biogram opublikowany w latach 1996-1997 w XXXVII tomie Polskiego Słownika Biograficznego). Protokół dostępu: http:// www.ipsb.nina.gov.pl/a/biografia/waclaw-sierakowski-h-ogonczyk [20.12.2016 r.]

Bieniarzówna Janina. 1969. Mieszczaństwo krakowskie XVII wieku. Z badań nad struktura spoteczna miasta. Kraków: Wydawnictwo Literackie. 
Bieniarzówna Janina, Małecki Jan M. 1984. Dzieje Krakowa. Kraków w wiekach XVI-XVIII. T. 2. Kraków: Wydawnictwo Literackie.

Chyra-Rolicz Zofia. 1986. Ludność. W: Andrzej Zahorski (red.). Warszawa w wieku Oświecenia. Wrocław: Zakład Narodowy im. Ossolińskich. S. 51-75.

Czeppe Maria. [on-line]. Hasło: Elżbieta Sapieżyna z Branickich. Internetowy Polski Słownik Biograficzny. Dostęp: www.ipsb.nina.gov.pl/a/biografia/elzbieta-sapiezyna-z-branickich [12.02.2017].

Dembowski Jan Sebastian. 1791. Komissarza Cywilno-Woyskowego, Rzecz krótka o fabryce sukienney Krakowskiey. Dla wiadomości publiczney do druku podana. Kraków: w Drukarni Szkoły Głównej Koronnej.

Furmanek Waldemar. 2008. Zarys humanistycznej teorii pracy (z perspektywy pedagogiki pracy). Toruń: Wydawnictwo Adam Marszałek.

Kotarbiński Tadeusz. 1965. Traktat o dobrej robocie. Wrocław: Zakład Narodowy im. Ossolińskich — Polska Akademia Nauk.

Kula Witold. 1956. Szkice o manufakturach w Polsce XVIII wieku. Cz. 1: 1720-1764. Cz. 2: 1764-1780. Cz. 3: 1780-1795. Wyd. 1. Warszawa: Państwowe Wydawnictwo Naukowe.

Lichocki F., Adam Naruszewicz, Johann F. Zöllner, Izabela Kleszczowa. 1979. Kraków za Stanistawa Augusta. Kraków: Wydawnictwo Literackie.

Luczak Andrzej Krzysztof, Krystyna Przybył. 2004. Korzenie przędzalnictwa i nie tylko...? „Biuletyn Izby Bawełny” 2004, nr 3. S. 15-20.

Łuczak Andrzej Krzysztof, Krystyna Przybył. 2007. Ewolucja polskiego włókiennictwa. „Przegląd Włókienniczy - Włókno Odzież Skóra” 2007, nr 1. S. 31-34.

Łuczak Andrzej Krzysztof, Krystyna Przybył. 2010. Wactaw Sierakowski - innowator w epoce Oświecenia. „Przegląd Włókienniczy — Włókno Odzież Skóra” 2010, nr 10. S. 21-23.

Olechnicki Krzysztof, Paweł Załęcki. 1997. Stownik socjologiczny. Toruń: Graffiti BC.

Pachoński Jan. 1956. Zmierzch stawetnych. Z życia mieszczan $w$ Krakowie $w$ XVII i XVIII wieku. Kraków: Wydawnictwo Literackie.

Rożek Michał, ks. Jan Kracik. 2010. Hultaje, złoczyńcy, wszetecznice w dawnym Krakowie. O marginesie spotecznym XVI-XVII w. Kraków: Wydawnictwo Petrus.

Sierakowski Wacław. 1797. Rękodzieto Fabryki Sukienney które w Krakowie 1786 dla wielu pożytków i zatrudnienia ubogich praca iest ustanowione przez WJX. Wactawa hrabie Sierakowskiego proboszcza katedralnego krakowskiego, iako fabryki sukienney protektora, w trzech czessciach zawarte praca i kosztem Autora. Cz. 1-3. W Krakowie: w Drukarni Szkoły Główney.

Snopek Jerzy. 1992. Prowincja oświecona. Kultura literacka Ziemi Krakowskiej w dobie Oświecenia 1750-1815. Warszawa: Instytut Badań Literackich — Wydawnictwo. 
Wawel Louis Józef. 1977. Urywki z dziejów i życia mieszkańców Krakowa. Kraków: Wydawnictwo Literackie.

Włodarczyk Zofia. 2011. Rośliny biblijne. Leksykon. Kraków: Instytut Botaniki im. W. Szafera PAN.

Zahorski Andrzej. 1984. Ludność. W: Stefan Kieniewicz (red.). Dzieje Warszawy. T. 2: Warszawa w latach 1526-1795. Cz. 3: 1720-1795. Warszawa: Państwowe Wydawnictwo Naukowe. S. 271-296.

\section{Marta Szymor-Rólczak}

\section{INCULTURATORY CONTEXTS IN "RĘKODZIEŁO FABRYKI SUKIENNEY..." BY WACŁAW SIERAKOWSKI}

The paper presents the inculturatory threads included in the work of Wacław Sierakowski, a canon from Cracow, entitled Rękodzieto Fabryki Sukienney... (Cracow 1797). The context indicated in the title is closely related to the work ethos presented in this publication. Although Sierakowski does not define outright the term "work", his considerations contain numerous discernible references to related concepts and categories, such as human needs which are man's driving force and associated types of motivation. Above all, however, he shows the impact of work on quality of life, described on the basis of the functions which labour fulfils. Writing about benefits of the founding of a factory, Sierakowski creates a contextual catalogue of work-related values in genere. The first part of Rękodzieto is dominated by reflections on benefits flowing from work of human hands, especially the cultural and social function of labour as an activity that requires communication and cooperation between individuals and groups.

\section{KEYWORDS}

Wacław Sierakowski; Rękodzieto Fabryki Sukienney...; acculturation; work; $18^{\text {th }}$ century cities 
Prace Polonistyczne, seria LXXII, 2017

ISSN: 0079-4791; e-ISSN: 2450-9353

DOI: $10.26485 / \mathrm{PP} / 2017 / 72 / 8$

Laurent Béghin

\section{« ALLER À LA POLOGNE, C'ÉTAIT ALLER À LA LUMIÈRE ». CLAUDE BACKVIS ET LA MÉDIATION DE LA CULTURE POLONAISE EN BELGIQUE FRANCOPHONE (1930-1960)}

\section{SŁOWA KLUCZOWE}

Backvis Claude; Belgia; transfer kulturowy; Międzywojnie; Lednicki Wacław; Polska; filologia słowiańska; Uniwersytet Wolny w Brukseli

Le nom de Claude Backvis est familier aux polonisants du monde entier. Fin connaisseur de la Renaissance et du baroque polonais, ce savant bruxellois de langue française a laissé une œuvre universitaire considérable dont la valeur ne s'est pas démentie au cours du temps. Un aspect de son activité est cependant moins connu : son travail de divulgateur de la culture polonaise auprès d'un public non spécialisé. S'étendant principalement des années trente au début des années soixante, son action de médiateur prit la forme de conférences et d'articles publiés dans diverses revues de haute vulgarisation, belges surtout. En l'absence d'une solide tradition philologique et historique en la matière, la Belgique d'alors ignorait à peu près tout de la culture polonaise. Dans ces conditions, il fallait, pour la lui présenter, mettre en place des stratégies d'acculturation. C'est à cellesci qu'est consacrée l'étude qu'on va lire ${ }^{1}$. Mais d'abord, il est nécessaire de rappe-

Laurent Béghin — dr, Université Saint-Louis Bruxelles, 11, rue d'Arlon, 1050 Bruxelles (Belgiques); e-mail: laurent.beghin@usaintlouis.be

1 Avec deux autres articles (Béghin 2015 et 2017), elle constitue un ensemble consacré à la réception de la littérature polonaise en Belgique francophone, principalement dans l'entre-deux-guerres. 
ler le parcours du médiateur et les circonstances dans lesquelles il inscrivit son œuvre dans la mesure où, comme nous le verrons, ces éléments influencèrent la médiation.

\section{Claude Backvis, premier slavisant belge}

Né le 24 avril 1910 à Schaerbeek, un faubourg de Bruxelles, Claude Backvis entama en 1927 des études de philologie classique à l'Université libre de Bruxelles $(\mathrm{ULB})^{2}$. Depuis l'année précédente, cet établissement de haut enseignement comptait une chaire de slavistique subventionnée entièrement par le gouvernement de la nouvelle république polonaise et confiée par celui-ci à un savant à la fois russisant et polonisant, Wacław Lednicki ${ }^{3}$. Grand lecteur de Dostoïevski, Backvis alla trouver Lednicki l'année même de son entrée à l'université et lui fit part de son souhait de s'initier au russe. Le système mis en place à Bruxelles prévoyant que l'étude de cette langue fût accompagnée de celle du polonais, le jeune homme acquit les rudiments des deux principaux idiomes slaves tout en poursuivant sa formation de philologue classique. Sous la direction de Lednicki puis des deux érudits qui le remplacèrent momentanément, Manfred Kridl et Karol Zawodziński, il se jeta de manière à la fois désordonnée et enthousiaste dans l'exploration du monde slave. Kochanowski, le Temps des Troubles, Słowacki, le roman historique polonais du XIX siècle :

Je découvrais, se souviendra-t-il, un monde tout à fait nouveau pour moi, un monde sur lequel je posais un regard impartial, curieux, voyant les choses telles qu'elles avaient été créées ${ }^{4}$.

En octobre 1932, après avoir obtenu l'année précédente son doctorat — l'actuelle maîtrise - en philologie classique avec un mémoire sur l'empereur Arcadius et enseigné quelque temps dans un lycée bruxellois, Backvis se rendit en Pologne où, grâce à une bourse du gouvernement belge, il demeura jusqu'en 1934. L'apprenti polonisant mit ce long séjour à profit pour préparer une thèse de doctorat sur Stanisław Trembecki. Mais les bibliothèques de Varsovie et de Cracovie, dont l'entrée lui fut probablement facilitée par les mots élogieux que Lednicki avait eus

2 Pour la biographie du polonisant belge on consultera Nowicka-Jeżowa 1999, Bingen et Blankoff 2001 et Borowski 2001. J'ai également utilisé le dossier professionnel de Claude Backvis conservé aux Archives de l'ULB.

3 Sur Wacław Lednicki (1891-1967) et la slavistique bruxelloise, voir Béghin 2017.

4 «Odkrywałem przecież samodzielnie nowy dla mnie świat, oglądany oczyma nieuprzedzonymi, nieblazowanymi, widzącymi rzeczy takimi, jakimi zostały stworzone " (Backvis 1939a : 147). Publié en janvier 1939, ce texte est cependant daté du mois de janvier de l'année précédente. 
pour lui dans une livraison de Przegląd Wspótczesny consacrée à la Belgique ${ }^{5}$, ne furent pas les seuls endroits qu'il visita. Passionné de théâtre, il fréquenta assidûment les scènes varsoviennes dont le niveau " exceptionnellement élevé " devait, d'après lui, « remplir de honte les Occidentaux " (Backvis 1935 : 254-255). À son arrivée en Pologne, le pays commémorait le vingt-cinquième anniversaire de la mort de Wyspiański. Backvis assista ainsi, au Théâtre National, à une représentation de Noces dont l'écho le hantait encore vingt ans après :

Je me souviens être sorti du théâtre et avoir marché longtemps par les rues nocturnes de Varsovie dans un état d'émotion qui ne devait pas être de beaucoup inférieur à celui des Cracoviens de 1901. Comme jadis dans leurs âmes, le dramaturge mort depuis un quart de siècle avait fait jaillir mon enthousiasme - à vrai dire, de rien, sans raison valable que la puissance d'illusion recelée dans son texte ; et ensuite, avec la même habileté de mage, il avait, au cours d'une même soirée, brisé cet enthousiasme et il me laissait plongé dans une tristesse sans borne, dans une amertume sans fond — à nouveau sans aucune raison raisonnable, puisqu'il ne s'agissait pas de mon pays et que je me trouvais parmi une nation à nouveau indépendante. (Backvis 1952 : 11)

Le séjour polonais fut également l'occasion de rencontres. Lednicki, dans la propriété duquel Backvis passa un mois entier, lui présenta quelques personnalités du grand monde. Des années plus tard, le savant polonais se souvenait encore de l'enthousiasme un peu naïf de son élève à l'idée de rencontrer chez son maître un vrai prince Lubomirski après avoir lu si souvent dans les livres le nom de cette illustre famille aristocratique ${ }^{6}$ ! Il est également probable que Lednicki, qui occupait aussi la chaire de littérature russe à l'Université Jagellonne, introduisit le philologue belge auprès d'universitaires polonais. On sait en tout cas qu'en

5 Lednicki 1932 : 206-207 : «Nie mogę pozatem nie wspomnieć tu o najrealniejszym i najkonkretniejszym wyniku mojej pracy pedagogicznej w Brukseli i pracy mego następcy, prof. M. Kridla. Mam na myśli naszego wybitnie uzdolnionego i równie wybitnie pracowitego słuchacza, dziś już doktora filologji klasycznej, p. Kl. Backvis. Poważne sukcesy w dziedzinie slawystiki (specjalnie literatury polskiej i literatury rosyjskiej, języków rosyjskiego i polskiego), które stały się owocem jego dotychczasowych wysilków poznawczych, dają gwarancję znakomitego powodzenia na polu samodzielnej i twórczej pracy naukowej p. Backvisa ". [Je ne peux ne pas rappeler ici le résultat bien réel et bien concret du travail pédagogique mené à Bruxelles par moi-même et par mon successeur, le prof. M. Kridl. Je veux parler de notre élève extraordinairement doué et travailleur, monsieur Cl. Backvis, aujourd'hui déjà docteur en philologie classique. Ses progrès dans le domaine de la slavistique (en particulier dans celui des littératures et des langues russe et polonaise), qui sont le fruit des efforts intellectuels qu'il a consentis jusqu'à présent, garantissent que M. Backvis développera avec succès une activité scientifique autonome et créatrice].

${ }^{6}$ " Another event impressed him also ; once Prince Konstanty Lubomirski, accompanied by some relative of his, visited us. Backvis was quite excited : "Imagine my reaction! Now I have suddenly seen a real Prince Lubomirski, after having read so much about his family in various old Polish texts!” "(Lednicki 1971 : 39). 
avril 1934, alors que son séjour touchait à sa fin, Backvis fut invité par Ignacy Chrzanowski et Stanisław Pigoń à exposer à Cracovie les résultats de certaines de ses recherches sur Trembecki (Backvis 1939a : 148, n. 2).

Rentré en Belgique, le jeune homme retrouva l'ULB, où il devint l'assistant d'abord de l'angliciste et comparatiste Paul de Reul, puis de Wacław Lednicki. Retenu à Cracovie par son enseignement de la littérature russe, ce dernier n'effectuait chaque année que deux brefs séjours bruxellois au cours desquels il donnait une série de leçons. Le reste de la formation en slavistique reposait en grande partie sur les épaules de son élève 7 . Toutefois, en dépit de son activité didactique, Backvis, dont beaucoup louèrent la capacité de travail hors du commun, acheva sa dissertation doctorale sur Trembecki et la publia en 1937 (Backvis 1937b). Toujours assistant de Lednicki, il travailla ensuite à une thèse d'agrégation - équivalent approximatif de l'actuelle habilitation à diriger des recherches - sur le théâtre de Wyspiański qu'il soutint dans le courant du mois de juillet $1939^{8}$.

Lorsque la guerre éclata, la section de philologie slave de l'ULB se trouva soudain privée de certains de ses meilleurs soutiens. Rentré en Pologne au mois d'août, Wacław Lednicki était retenu dans Cracovie occupée. Le médiéviste Alexandre Eck, qui enseignait l'histoire de la Russie, avait repris du service dans l'armée française9. Backvis les suppléa officiellement à partir du 14 novembre 1939. Deux ans plus tard, après la fermeture de l'ULB, le slavisant poursuivit clandestinement son activité ${ }^{10}$. En 1947, Lednicki, qui était parvenu à gagner les États-Unis en 1940 et avait obtenu une chaire à Berkeley, démissionna de son poste bruxellois non sans avoir chaleureusement encouragé les

${ }^{7}$ Pendant l'année 1937-1938, le slavisant belge était censé assurer les enseignements suivants : Introduction à l'histoire des littératures slaves, Histoire des littératures slaves, Histoire approfondie des littératures slaves I, Explication approfondie d'un auteur russe ou polonais, Histoire approfondie des littératures slaves II, Explication approfondie d'un auteur antérieur au XVIII e siècle et Explication à livre ouvert d'un auteur russe ou polonais! Université libre de Bruxelles 1937 : 4-15. Ces cours étaient inscrits au programme de l'Institut de philologie et d'histoire orientales et slaves créé en 1931 au sein de la Faculté de philosophie et lettres à l'initiative, entre autres, d'Henri Grégoire et de l'historien Jacques Pirenne.

${ }^{8}$ Lednicki 1971 : 40. Remanié, ce travail fut publié treize ans plus tard (Backvis 1952).

${ }^{9}$ Lettre du 9 octobre 1939 d'Alexandre Eck au recteur de l'Université de Bruxelles. Archives de l'ULB, dossier professionnel d'Alexandre Eck.

${ }^{10}$ Le 25 novembre 1941, l'ULB ferma ses portes en signe de protestation contre l'ingérence allemande dans les affaires de l'université. Certains étudiants s'inscrivirent dans d'autres établissements d'enseignement supérieur (Louvain, Liège). Plusieurs suivirent en revanche les cours clandestins organisés en divers lieux de Bruxelles. Sur le sujet, je renvoie à Despy-Meyer, Dierkens et Scheeling 1991. L'information sur la participation de Backvis à ces activités non autorisées par l'occupant provient de Bingen 2001 : 70. Le dossier professionnel du slavisant belge est toutefois muet sur cette période. 
autorités universitaires à choisir, pour le remplacer, son ancien élève et assistant ${ }^{11}$. Le 22 novembre de cette année, Backvis, qui, depuis 1939, assurait presque à lui seul la totalité des enseignements de slavistique sous le statut précaire de suppléant, fut enfin nommé chargé de cours. Professeur ordinaire cinq ans après, il enseigna sans relâche à l'ULB jusqu'en 1977 et produisit une œuvre abondante et variée, consacrée surtout à la Pologne renaissante et baroque, mais qui n'oublia jamais la Russie. La retraite ne le détourna pas de la philologie. C'est en effet pendant les dernières années de sa longue existence qu'il composa ce qui est probablement son maître-livre, les deux volumes d'un monumental Panorama de la poésie polonaise à l'âge baroque qui parurent en 1995. Il s'éteignit trois ans plus tard, à Bruxelles, le 16 mai 1998.

\section{La Kulturgeschichte comme médiation culturelle}

Conscient de l'ignorance relative de l'Occident à l'égard des peuples slaves, Backvis a d'emblée assigné un rôle spécifique aux slavisants occidentaux. À la différence de ses collègues polonais, tchèques ou russes, un philologue belge ou français n'a pas pour but d'ajouter "de petits cailloux à des édifices déjà achevés ", ni de " commenter consciencieusement quelque chef-d'œuvre ", mais bien de " réveiller en lui l'esprit de nos prédécesseurs de l'époque romantique » et de "brosser pour le lecteur occidental les grandes fresques des cultures slaves $»^{12}$. Il a le droit de bousculer les jugements et les hiérarchies de valeur établis par ses

11 « Laissez-moi maintenant vous adresser une prière ou plutôt vous faire une suggestion. L'université vient de déclarer la vacance de mes enseignements. Il me semble que la tâche de me remplacer n'est pas difficile. Vous avez le dr. Claude Backvis, mon ancien élève et assistant. Je considère de mon devoir de vous dire qu'à mes yeux Mr Backvis est actuellement le plus brillant slavisant d'expression française que je connaisse. Pendant vingt ans d'étude et de travail consacrés à la philologie slave Mr Backvis a acquis une érudition absolument exceptionnelle et une compréhension pour les problèmes slaves tout à fait supérieure. La probité scientifique qui le caractérise, son énergie morale et ses grandes qualités spirituelles font de lui, déjà actuellement, sans parler de l'avenir, un professeur de la plus haute distinction. En plus il mérite cette nomination par le fait même qu'il est [mots illisibles] le premier slavisant belge, il est le résultat vivant de la si longue et si heureuse collaboration belgo-polonaise dans ce domaine ". Lettre de Wacław Lednicki aux autorités de l'ULB, Berkeley, 3 août 1947. Archives de l'ULB, dossier "Lednicki, Venceslas ».

12 "Celem jego [badacza cudzoziemca - LB] być powinno nie dokładanie malutkich kamyczków do już wykończonych budowli, nie żmudne spisywanie drobnych przyczynków do wielkich dzieł, lecz obudzenie w sobie twórczego ducha naszych przodków z okresu romantyzmu i wskrzeszenie przed czytelnikami Zachodu wielkich fresków kultur słowiańskich ". Backvis 1939a : 146. On notera que Backvis a exposé sa conception de la slavistique surtout dans des textes publiés en polonais dans Przegląd Wspótczesny (1922-1939), une revue cracovienne à laquelle Wacław Lednicki collaborait activement et dont le ton de haute vulgarisation et l'intérêt pour les questions politiques et culturelles ne sont pas sans rappeler Le flambeau. Manière de contre-chant à la production française de notre auteur, ces articles en montrent la trame et en constituent le commentaire. 
confrères d'Europe centrale et orientale ${ }^{13}$; surtout, délaissant les thèmes trop périphériques, il se doit d'élire un sujet suffisamment vaste pour lui permettre de saisir un moment crucial de l'évolution de telle ou telle culture spécifique ${ }^{14}$. Étudier Trembecki offrait à Backvis sinon le prétexte, du moins la possibilité de se plonger dans l'époque de Stanislas-Auguste et, partant, de fournir à un public non polonais un de ces vivant panoramas auxquels, d'après lui, devaient tendre les philologues étrangers ${ }^{15}$. Au soir de son existence, le slavisant bruxellois n'avait guère varié et déclarait avoir conçu son grand ouvrage sur la poésie $\mathrm{du} \mathrm{XVII}^{\mathrm{e}}$ siècle non pour les Polonais, mais pour « ceux des lettrés d'Occident qu'intéresse le baroque littéraire " (Backvis 1995 : 14-15). Chez lui, la Kulturgeschichte confinait indéniablement à la médiation culturelle.

Dans de telles conditions, on ne s'étonnera pas que Backvis se soit adonné autant à la haute vulgarisation qu'à la recherche scientifique proprement dite. Fidèle aux principes qu'il s'était fixés au commencement de sa carrière, il ne ménagea point ses efforts, au moins jusqu'aux années soixante, pour faire connaître auprès d'un public non spécialiste diverses facettes de la culture polonaise. Si l'on excepte deux traductions (Kuncewiczowa 1945 ; Krasiński 1948), ce travail de médiation prit la double forme de conférences et d'articles parus dans des revues généralistes ${ }^{16}$.

Introducteur de la culture polonaise en Belgique, Backvis tenait en même temps à informer de ses efforts les représentants de la culture dont il assurait la médiation.

13 "Chcę jedynie powiedzieć, że badacz obcy, pragnący skierować uwagę swych rodaków na wielkie i dotąd zapoznane wartości, wniesione do skarbnicy kultury europejskiej przez narody słowiańskie, posiada prawo wyboru, prawo ustanawiania nowej hierarchii owych wartości, oddawania pierwszeństwa tym a nie innym zjawiskom w wielkiej spuściźnie Slowiańszczyzny — ma, słowem, prawo być w swych sympatiach i klasyfikacjach nowatorem i rewolucjonistą ". Backvis 1939a : 146 .

${ }^{14}$ Backvis 1939a : 147. « Pozostawało znaleźć temat położony nie na peryferii, lecz w samym ognisku ogólnych problemów, zarysowujących się przy studiowaniu ewolucji polskiej kultury » [Il fallait trouver un sujet situé non à la périphérie, mais au cœur même des problèmes généraux qui apparaissent lorsqu'on étudie l'évolution de la culture polonaise].

${ }^{15}$ Dans un article publié en 1935 dans Przegląd Wspótczesny et intitulé « Kilka uwag o Trembeckim " [Quelques remarques sur Trembecki], Backvis précisait d'entrée de jeu que les considérations qu'on allait lire étaient extraites de l'ouvrage qu'il préparait sur Trembecki, une monographie écrite en français et destinée avant tout aux étrangers et non aux Polonais (Pragnę na wstępie podkreślić, że rozważania poniższe pochodzą ze szczegółowej monografii o Trembeckim, napisanej przeze mnie po francusku, a zatem dla cudzoziemców przenaczonej — Backvis 1935 : 305).

${ }^{16}$ Il est un au autre aspect de l'action médiatrice de Claude Backvis que l'on abordera pas ici : les quelques textes de vulgarisation qu'il donna en néerlandais. Parus entre 1947 et 1954, les dix-huit volumes de l'Algemene Winkler Prins Encyclopaedie (Amsterdam) contiennent de nombreux articles de littératures russe et polonaise signés Backvis. Par ailleurs, en 1960, le slavisant procura une longue introduction — traduite du français — à la version néerlandaise des Paysans de Reymont publiée par une maison d'édition flamande de Hasselt (Backvis 1960). 
La consultation de la presse belge de l'époque - en particulier celle du Soir et de L'Indépendance belge, deux grands quotidiens libéraux bruxellois — permet de se faire une idée de l'activité de conférencier de Claude Backvis. De 1937 à 1969, ce dernier donna plusieurs causeries sur des sujets polonais ou russes ${ }^{17}$. Quant aux lieux de ces conférences, quand il ne s'agit pas de l'ULB elle-même, ils sont généralement liés d'une façon ou d'une autre à l'université de Bruxelles. Ainsi Backvis s'adressa-t-il à plusieurs reprises aux Amis des littératures slaves, dont le siège se trouvait à la Cité universitaire ; il parla aussi à l'Institut des Hautes Études de Belgique, un établissement né après la Première Guerre mondiale des cendres de l'Université nouvelle, elle-même émanation, un temps dissidente, de l'ULB.

Le même tropisme bruxellois était à l'œuvre dans les études de haute vulgarisation que Backvis donna dès le début de sa carrière. Des principales revues qui se partagèrent ses articles destinés à un public non spécialisé, une seule - Le monde slave - était française ${ }^{18}$. Dirigée depuis 1922 par Paul de Reul, dont on se souvient que Backvis fut un temps l'assistant, la Revue de l'Université de Bruxelles publiait des articles de bonne facture, généralement signés d'universitaires bruxellois, sur les sujets les plus divers. Un principe repris, quoique avec des ambitions et des dimensions plus modestes, dans le Bulletin des anciens étudiants de l'Université libre de Bruxelles. Tout aussi généralistes et alimentés par des professeurs de l'ULB étaient les Cahiers du libre examen. Mais ce fut surtout Le flambeau qui accueillit l'essentiel des textes de vulgarisation du philologue belge. Conçu à l'origine comme une revue de politique, nationale et internationale, mais ayant très tôt ouvert ses pages à des sujets historiques ou littéraires, ce mensuel bruxellois libéral possédait de bonnes raisons de s'intéresser au monde slave en général, à la Pologne en particulier (Béghin 2014). Parmi ses fondateurs figuraient en effet Anatole Mühlstein, secrétaire de l'ambassade de Pologne en Belgique, et Henri Grégoire, byzantiniste et slavisant. Ces deux hommes entretenaient des

${ }^{17}$ En se limitant aux conférences sur des thèmes polonais, on peut citer « Coup d'œil sur les dernières années de la littérature polonaise " (7 avril 1938. Les Amis des littératures slaves), "Réflexions contemporaines sur de vieux textes politiques polonais" (23 février 1939. Les Amis des littératures slaves), "La démocratie polonaise au XVIe siècle " (14 novembre 1939. Institut des Hautes Études), "Études sur l'histoire du protestantisme en Pologne " (30 janvier 1948. Institut des Hautes Études), "Les espérances et l'échec du protestantisme polonais " (9 mai 1948. Foyer de l'Âme), "Trois témoignages sur la génération tragique (1570-1630) (8 juin 1948, Institut d'Études polonaises de Belgique), une causerie sur Mickiewicz (décembre 1955. ULB), une évocation de l'évolution politique de Joachim Lelewel (9 mars 1962. ULB), "Le rôle de la Pologne dans la culture européenne et pourquoi il est encore imparfaitement connu " (25 mars 1968. Gand), "Un pionnier du renouveau théâtral dans la première moitié du XX" siècle : Stanislas Wyspiański (1869-1907)» (17 décembre 1969. Institut des Hautes Études).

18 Sur cette revue de haute vulgarisation fondée à Paris en 1917 et active jusqu'en 1938 (avec une interruption entre 1918 et 1924), voir Bernard 2002. 
liens étroits avec l'ULB : le premier y avait suivi, avant la guerre, les cours du philosophe Georges Dwelshauwers ; le second y enseignait depuis 1909 (Béghin 2015 : 32). Ils n'étaient du reste pas les seuls collaborateurs du Flambeau à graviter autour de l'université bruxelloise. De Paul de Reul à Wacław Lednicki, du romaniste Lucien-Paul Thomas au philosophe Eugène Dupréel, maints contributeurs de la revue professaient à l'ULB, de sorte qu'il n'est guère étonnant que Backvis ait publié son tout premier article dans le mensuel de Grégoire et lui soit resté fidèle de nombreuses années.

Ajoutons à cela une substantielle introduction à l'Anthologie de la poésie polonaise du XV $V^{e}$ au XX siècle procurée en 1961 par Marian Pankowski (Pankowski 1961), qui fut l'élève puis le collègue de Claude Backvis, et l'on ne pourra que constater que, passe-t-elle par la parole ou par l'écrit, l'œuvre de vulgarisation du slavisant belge est liée, directement ou indirectement, à l'atmosphère intellectuelle de l'ULB. Dans quelle mesure les lieux de la médiation influencèrent-ils la médiation elle-même, c'est ce qu'il nous faut à présent étudier.

\section{Les stratégies de la médiation}

Montrer certaines facettes de la culture polonaise à un public cultivé mais connaissant mal un pays éloigné qui venait de recouvrer son indépendance après une éclipse politique de plus d'un siècle et dont la langue n'était guère enseignée en dehors de ses frontières requérait assurément le recours à quelques stratégies de médiation.

Familière aux comparatistes, la première consiste à multiplier les rapprochements entre écrivains étudiés et auteurs connus, ou censés l'être, du public auquel le médiateur s'adresse. Backvis ne se priva pas d'utiliser abondamment ce procédé. À ce titre, son premier article, publié en 1932, est emblématique. Présentation de l'œuvre de Juliusz Słowacki, un poète peu traduit en français et auquel le slavisant belge voua une tendresse particulière, le texte accumule les analogies. "Quelques scènes d'une vérité et d'une puissance shakespearienne se détachent " de Kordjan, entre autres celle dans laquelle l'écrivain "a représenté avec une profondeur et une verve dignes de Tacite les recoins lamentables de $[\mathrm{s}]$ âmes despotiques et veules " de Nicolas ${ }^{\mathrm{I} r}$ et du grand-duc Constantin (Backvis 1932: 34). Anhelli «se ressent d'une influence discrète de Dante" (Backvis 1932 : 38) ; Lilla Weneda " est une tragédie d'Euripide, telle que celui-ci l'aurait écrite au XIX ${ }^{\mathrm{e}}$ siècle " (Backvis 1932 : 41); quant à l'Esprit-Roi, « c'est vraiment à l'art pindarique qu'il faut [le] comparer» (Backvis 1932 : 55). Plus rarement, Backvis convoque aussi musiciens et peintres : Beniowski est "l'équivalent en littérature de l'un de ces 
opéras colossaux de Wagner " (Backvis 1932 : 46) et l'Esprit-Roi "rappelle de près la Tétralogie wagnérienne et les tableaux de Rossetti " (Backvis 1932 : 55).

Saturé de comparaisons, l'article de 1932 confine presque, du moins sous ce rapport, à la caricature. N'oublions cependant pas qu'il s'agit là du premier opus d'un jeune homme de vingt-quatre ans passionné de littérature et encore tout à la joie enthousiaste de partager avec ses compatriotes sa récente découverte des lettres polonaises. Plus maîtrisés, les textes ultérieurs seront moins riches en rapprochements. Néanmoins, s'il l'utilisa avec davantage de sobriété, Backvis n'abandonna jamais le procédé. Ainsi lit-on dans un article de 1935 que le critique Stefan Kołaczkowski est « une manière de Papini polonais » et que le " naturalisme fantasmagorique " de Juliusz Kaden-Bandrowski "ne laisse pas de rappeler Breughel ou Rops » (Backvis 1935 : 242 et 251). En 1955 encore, dans un texte rédigé à l'occasion du centième anniversaire de la mort de Mickiewicz, le slavisant évoquera Milton, Byron et les peintres du Quattrocento pour faire sentir à ses lecteurs la grandeur du poète de Pan Tadeusz (Backvis 1955 : 273, 276 et 286).

Le recours à l'analogie permettait en outre d'affirmer le caractère indiscutablement européen de la culture polonaise. Mais de quelle Europe s'agit-il ? Ici intervient un deuxième procédé de médiation, qui prend plus spécifiquement en compte le segment du public belge auquel Backvis s'adressait : l'insistance sur l'ancrage de la Pologne dans la tradition rationaliste occidentale.

On a vu que le slavisant collaborait principalement à des publications liées peu ou prou à l'ULB. Fondée en 1834 par un groupe de libéraux proches de la franc-maçonnerie, l'université de Bruxelles, dont la devise éloquente est Scientia vincere tenebras [Vaincre les ténèbres par la connaissance], s'est d'emblée pensée comme l'héritière des Lumières. Anticléricale et résolument laïque dans une Belgique longtemps dominée par le parti catholique, elle a prôné, au nom du libre examen, une recherche scientifique affranchie de toute contrainte religieuse et a donné au libéralisme puis au socialisme belges quelques-unes de leurs figures les plus éminentes.

Dès lors il n'est guère surprenant que la Pologne à laquelle vont les sympathies de Backvis soit précisément celle qui semble le mieux correspondre à ce prisme idéologique, à savoir celle de la Renaissance et des Lumières. La Pologne humaniste, tolérante et démocratique du $\mathrm{XVI}^{\mathrm{e}}$ siècle suscite plus d'une fois l'émerveillement du savant belge :

Après Aeneas Sylvius Piccolomini, Érasme, Melanchton, Bucer, de Thou s'étonnent de l'admirable latinité et de l'érudition raffinée de leurs amis polonais. Dans de telles circonstances, il n'est pas étonnant que tant de provinces limitrophes se soient pressées 
en un mouvement spontané et confiant autour de la Pologne, car aller à la Pologne, c’était aller à la lumière. (Backvis 1939e : 399-400)

Et de vanter, dans le même article de 1939, la littérature polonaise de la Renaissance - qu'elle s'exprime en latin ou en polonais —, la seule parmi ses sœurs européennes

où il soit si souvent question, et dans des termes plus chauds, plus cordiaux, plus sincères, de l'injustice sociale, de la responsabilité de l'élite envers le pauvre peuple et du sort misérable qui attend une société qui n'est pas fondée sur la justice et l'amour. (Backvis 1939e : 401)

Quelques années plus tard, Backvis chantera de nouveau cet « humanisme splendide et profond " qui " a fleuri au bord de la Vistule et du Niémen " et ces Polonais du siècle d'or, " qui, à peu près seuls dans l'Europe d'alors, savaient parler à leurs rois debout et les yeux dans les yeux " (Backvis 1944: 322 et Backvis 1956 : 272).

La fascination du règne de Stanislas-Auguste et des réformes que le souverain et son entourage tentèrent d'introduire constitue l'autre face de cette admiration. Loin d'être un simple exercice académique, la préparation et la rédaction de la grande étude sur Trembecki furent parcourues d'une adhésion généreuse aux idéaux qui animaient le dernier roi de Pologne et ses partisans. Débordant de sympathie pour son sujet, le jeune savant avait « revécu [...] les enthousiasmes du Grand Sejm » et « haï Targowica comme n'importe quel Polonais pourrait le haïr " (Backvis 1933 : 195) ${ }^{19}$. Pareille attitude le poussait à fustiger la Pologne lorsqu'elle négligeait l'héritage des Lumières. Passant en revue la vie littéraire polonaise des années trente, il regrettait ainsi que " le XVIII siècle [...] continu[ât] à être traité avec une indifférence scandaleuse " (Backvis 1937a : 129). Le degré d'adhésion aux principes de l'Aufklärung formait par ailleurs la mesure de son appréciation de certains auteurs, quitte à bousculer parfois les hiérarchies établies par l'historiographie polonaise romantique et patriotique. Mickiewicz est sans contredit un immense écrivain, mais sa "méfiance sarcastique à l'égard de la raison raisonnante et mécaniciste du XVIII ${ }^{\mathrm{e}}$ siècle et en général envers l'attitude spirituelle du siècle des Lumières " fut la source "d'une espèce d'acharnement souvent partial et - pourquoi ne pas le dire ? - bien souvent injuste et pour lui-même égarant » à l'endroit de l'époque qui le précéda (Backvis 1956 : 278).

${ }^{19}$ Réuni de 1788 à 1792, le Grand Sejm (c’est-à-dire la Grande Diète) entendait réformer en profondeur la monarchie polonaise après le partage de 1772. Les adversaires des réformes, parmi lesquels maints riches propriétaires terriens, constituèrent une ligue, la confédération de Targowica, et demandèrent l'aide de la Russie, favorisant ainsi le second partage du pays (1792). 
Et Backvis d'ajouter quelques lignes qui ne déplaisaient certainement pas aux lecteurs du très laïc Flambeau :

Comme il est arrivé à tant de romantiques, Mickiewicz a eu par trop souvent le Seigneur Dieu dans sa manche et il a cru trop facilement que ce qui était en définitive un jeu littéraire avec des formes néo-médiévales possédait en soi et de nature une éminente valeur métaphysique. (Backvis $1956: 279)^{20}$

Sans être une constante, les saillies anticléricales ne sont d'ailleurs pas rares dans les textes de vulgarisation du slavisant bruxellois. Évoquant la décadence de la république nobiliaire au XVII ${ }^{\mathrm{e}}$ siècle, Backvis reprochait ainsi à l'Église catholique d'avoir choisi

la voie qui s’avéra la plus ruineuse pour la santé morale et intellectuelle de la Pologne : celle de la pénétration insidieuse, de la démagogie, de l'abaissement systématique du niveau des controverses et des débats ; elle flatta tous les instincts les plus bas, aussi bien les appétits de la foule misérable et interlope vivant des sportules des couvents que les préjugés de caste de la noblesse ; par une surenchère scolaire menée dans les règles de l'art, elle élimina les gymnases et les académies qui entretenaient les grandes traditions de l'humanisme; par la tyrannie de la rue, par les émeutes et les pillages, elle sut tarir les sources de la propagande adverse; par l'usage du liberum veto et de la tactique parlementaire, elle sut paralyser la vie politique quand celle-ci voulait se diriger d'après les nécessités de l'État et non d'après les mots d'ordre de la réaction religieuse. (Backvis 1939e : 404)

$\mathrm{Au} \mathrm{XV}$ siècle déjà, l'asservissement à la politique pontificale avait offert la Pologne " en holocauste à Varna » (Backvis 1939d : 236) ${ }^{21}$; trois cents ans plus tard, sous

${ }^{20}$ S'adressant à des lecteurs polonais, le slavisant belge ne se priva pas de leur reprocher leur désintérêt pour le XVIII siècle et d'estimer certaines gloires nationales à l'aune de leur rapport aux Lumières et au règne de Stanislas-Auguste. «Fałszem historycznym jest mit o owej rzekomej regeneracji, wykwitły na płodnym gruncie szeroko rozpowszechnionych uprzedzeń w stosunku do wieku Oświecenia. Utrwalanie tych uprzedzeń i gloryfikowanie ludzi, którzy je reprenzentują, ludzi, którzy udaremnili dzieło Stanisława Augusta i ponoszą odpowiedzialność za rozbiory — to robota zgubna dla Polski, tym zgubniejsza, że ma ona zapewnione powodzenie, jak wszystko, co pochlebia złym instynktom i wadom narodu [Le mythe d'une telle régénération [de la Pologne entre 1795 et la fin de la période napoléonienne] est un faux historique qui a fleuri sur le sol fertile des préjugés largement répandus à l'encontre du siècle des Lumières. La perpétuation de ces préjugés et la glorification d'individus qui les représentent, d'individus qui ont réduit à néant l'œuvre de Stanislas-Auguste et portent la responsabilité des partages, tout cela est une œuvre funeste pour la Pologne, d'autant plus funeste qu'elle remporte un certain succès, comme tout ce qui flatte les bas instincts et les tares de la nation]. Et Backvis de reprocher vertement au Stefan Żeromski de Cendres d'avoir fait le lit de ces préjugés et exalté le clinquant de la période napoléonienne. Backvis 1936 : 316.

${ }^{21}$ Le 10 novembre 1444, les armées croisées commandées par le roi de Pologne et de Hongrie, Ladislas III Jagellon, furent défaites par les Ottomans à Varna, en Bulgarie. Le souverain chrétien perdit la vie dans la bataille. 
le règne éclairé de Stanislas-Auguste, le camp conservateur restait plongé « dans le sombre cléricalisme de la période saxonne" (Backvis 1933 : 209).

La célébration de l'humanisme renaissant et des Lumières et la discrète polémique anticléricale qui en résultait devaient plaire à un public libéral, laïc et volontiers libre-penseur et lui rendre la Pologne - ou du moins une certaine Pologne - plus familière. Au fond, insister sur ces traits de la culture polonaise revenait à affirmer que le pays de Frycz Modrzewski et des antitrinitaires, de Stanisław Trembecki et de Hugo Kołłątaj avait cultivé, au même titre que la France, l'Italie ou la Belgique, une tradition intellectuelle européenne dont l'ULB et les milieux qui gravitaient autour d'elle se comptaient volontiers parmi les principaux dépositaires.

Par ailleurs un autre aspect de l'ancienne Res publica était susceptible, quoique de manière moins évidente, de créer une impression de déjà-vu et, par là même, de susciter la sympathie et l'intérêt. Il n'est pas impossible en effet que l'accent mis par le philologue bruxellois sur le degré remarquable atteint par la culture polonaise dans le cadre de la république nobiliaire, c'est-à-dire d'un espace linguistiquement hétérogène où le polonais côtoyait d'autres idiomes tout en ayant le pas sur eux, ne sonnât chez Backvis - qui n'hésite pas à parler à ce propos d' "impérialisme pacifique " (Backvis 1946 : 323) — et chez certains de ses lecteurs comme l'évocation implicite et mélancolique d'un État belge où le français avait longtemps dominé avant d'être, précisément dans cet entre-deuxguerres où notre slavisant commence à publier, mis à mal par les revendications du Mouvement flamand. Si elle est hasardeuse, cette hypothèse n'a rien d'invraisemblable. Dans les années vingt, alors que les débats autour de la création d'une section néerlandaise au sein de l'université de Gand puis, quelque temps plus tard, de la "flamandisation " complète du haut enseignement gantois agitaient les esprits, Le flambeau n'avait-il pas défendu les minorités flamandes de langue française (Béghin 2014 : 109) ? De Maurice Maeterlinck à Victor Horta, ces dernières avaient fourni à la Belgique du début du $\mathrm{XX}^{\mathrm{e}}$ siècle quelques-unes de ses figures les plus significatives. Peut-être Backvis y songeait-il ou induisait-il ses lecteurs à y songer lorsque, décrivant la république nobiliaire, il évoquait les kresy, ces confins orientaux — lituaniens, biélorusses ou ukrainiens — qui « ont donné à la Pologne tant de poètes, d'écrivains, de publicistes, d'hommes de guerre et de héros " (Backvis 1939e : 397).

S'appuyant sur des éléments que d'aucuns jugeront trop ténus, le paragraphe précédent n'emportera peut-être pas l'adhésion. Il n'empêche que l'usage anachronique du passé pour polémiquer avec le présent et abolir d'un coup la distance entre autrefois et aujourd'hui est loin d'être exceptionnel dans les articles 
de vulgarisation de Claude Backvis. Ce trait est particulièrement remarquable dans trois études parues dans Le flambeau au cours des derniers mois de 1939.

Quand l'Allemagne envahit la Pologne, la Belgique réaffirma sa neutralité et ne s'engagea pas aux côtés des Alliés. Une partie de l'opinion publique était néanmoins francophile. Tel était le cas des libéraux du Flambeau qui, sans contester la politique étrangère du royaume, récusaient en revanche la neutralité des consciences et prirent fait et cause pour " ceux dont nous fûmes jadis les frères d'armes et qui restent pour nous des frères " (Le flambeau 1939b : 227). En cet automne 1939, la tâche que s'était assignée cette revue née dans la Belgique occupée de 1918 ne laissait aucun doute :

éclairer, réchauffer l'opinion, prêcher la résistance aux sceptiques, aux cyniques qui affectent de ne pas savoir où est le bon droit ; [..] ; aux perfides qui cherchent à nous rendre suspects nos véritables, nos seuls amis ; aux prudents qui voudraient nous empêcher d'admirer l'héroïsme de ceux qui se battent pour nous et de saluer la Pologne, qui arrête sur la Vistule l'envahisseur, qu'il y a vingt-cinq ans nous arrêtions sur l'Yser. (Le flambeau 1939b : 228) 22

Publié en septembre 1939, le numéro contenant ce témoignage d'admiration pour la Pologne combattante proposait également un article de Backvis intitulé "La Pologne et Dantzig ». Les livraisons d'octobre et de novembre accueillirent deux autres textes du slavisant belge : "L'ancienne république polonaise " et "Les trois premiers partages de la Pologne ». Hommage appuyé à la grandeur de la vieille république nobiliaire, ces esquisses historiques ne se privaient pas de dénoncer les menées politiques et militaires de ceux qui par le passé furent les ennemis de la Pologne. Des exemples ? Les sorties contre les chevaliers teutoniques, "ces étranges propagandistes de la foi » (Backvis 1939d : 232), ne manquent pas. C'est un Polonais, Paweł Włodkowic, qui, au XV siècle déjà,

22 Par ailleurs, le 20 novembre 1939, Le flambeau publia un Manifeste qui avait déjà paru dans la presse le 18 octobre de la même année. Favorable aux Alliés ("Les soussignés ne peuvent pas ne pas choisir entre ceux qui ont voulu la guerre et se sont concertés pour la déclencher le moment venu, et ceux qui, poussant à l'extrême l'esprit de conciliation, ont tout fait pour résoudre le conflit germano-polonais par voie de négociations. [...]. Ils ne peuvent consentir à mettre sur le même plan leurs anciens compagnons d'armes et ceux qui, pendant près de quatre ans, leur infligèrent la plus cruelle des occupations militaires »), le texte s'achevait sur ces lignes : "Au moment où la Pologne, saccagée et martyrisée, vient d'être partagée pour la quatrième fois, au mépris des engagements les plus formels, par deux puissances que tout semblait opposer, mais que l'impérialisme et l'esprit de conquête ont réunies, ils [les signataires] envoient à cette malheureuse nation l'expression de leur admiration et de leur douloureuse et respectueuse sympathie " ( Un manifeste ", Le flambeau, 20 novembre 1939, pp. 502-503). Nul doute que Backvis eût signé ce texte si celui-ci n'eût été réservé aux professeurs universitaires - en 1939, le polonisant bruxellois n'était encore qu'assistant — et aux membres des académies. 
démasqua devant les dignitaires de l'Église rassemblés en concile à Constance "l'hypocrisie de 'l'œuvre civilisatrice' [de l'Ordre] caractérisée par le pillage, le massacre, les tortures et la dévastation " (Backvis 1939d : 230). Et Backvis d'opposer ensuite la violence des moines-soldats à "l'impérialisme pacifique " de la Pologne dont il a déjà été question plus haut :

Combien [...] les auditeurs de Constance devaient-ils être frappés lorsqu'ils apprenaient tout à coup, de la bouche de l'éloquent défenseur, que les Polonais étaient en train, depuis trente ans, d'évangéliser dans la paix, l'amour et l'égalité ces mêmes Lituaniens que les Teutoniques entendaient soumettre par une croisade de sang et de feu et que ces secours que les moines-soldats réclamaient à la religion de l'Occident pour des buts pieux devaient servir en réalité à lutter contre un peuple chrétien pour plus sûrement exterminer un autre peuple en train de le devenir! (Backvis 1939d : 230)

Quant à la Prusse de Frédéric II, ce souverain à " la perfidie ironique et méchante » (Backvis 1939f : 525), elle apparaît comme la responsable principale de la mort d'une brillante civilisation. Ainsi, retraçant l'histoire de Dantzig, Backvis note qu'

à mesure que l'araignée prussienne tisse autour de la ville des filets plus solides, [la vieille cité hanséatique] résiste avec un désespoir plus farouche car elle sait, elle devine que c'en sera fait de ses traditions de liberté, de vie facile et brillante ». (Backvis 1939d : 240)

Ce n'était pas la première fois que le slavisant belge exprimait semblable hostilité. Enfant alors que Bruxelles était occupé par les Allemands, Backvis avait grandi dans un climat de défiance relative envers l'ennemi d'hier. Rien d'étonnant dès lors à ce qu'il écrivît en 1933, quand Hitler venait d'accéder au pouvoir, que, dans les dernières années du règne de Stanislas-Auguste, « la seule faute des Polonais est d'avoir cru que les ministres prussiens étaient des gens d'honneur, et cette faute, si faute il y a, ne leur est pas personnelle». (Backvis $1933: 211$ )

L'Allemagne est sans contredit la cible majeure des articles de 1939. Influencé peut-être par une formation qui prévoyait l'étude conjointe des lettres polonaises et russes, Backvis est en revanche infiniment plus clément envers la Russie ${ }^{23}$.

${ }^{23}$ On ne peut en outre exclure une certaine slavophilie de la part de Backvis. Contrairement à son maître Wacław Lednicki, qui déniait aux peuples slaves la moindre parenté culturelle (Béghin 2017), le savant belge a plus d'une fois insisté sur l'unité fondamentale du monde slave, en particulier sur les liens unissant la Pologne et la Russie. « [...] cette fois encore, nous pouvons conclure que les grandes tendances de la littérature polonaise suivent le même chemin que celles qui dominent la littérature russe (retour à l'épopée contemporaine, abandon du 'formisme' et des divers modernismes, crise de la poésie). [...]. À mesure que la culture polonaise se démocratise, à mesure qu'elle cesse d'être l'apanage d'une caste pour devenir l'expression d'une nation, les simi- 
Certes, dans les trois esquisses historiques publiées dans les premiers mois de la guerre, il admet le rôle néfaste joué par Catherine II dans les partages. Sous sa plume, les Russes apparaissent cependant comme des acteurs secondaires manipulés par la Prusse. Par leur "vanité, [leur] brutalité et [leur] maladresse, ils «s'amuseront à opposer force contre force en Pologne sans vouloir remarquer qu'ils gâchent ainsi les possibilités d'une féconde collaboration qui s'offraient à eux et finiront par se charger de toute la haine, tout simplement pour faire la politique du roi de Prusse " (Backvis 1939f : 525)24. Dans des textes antérieurs, Backvis avait pourtant montré davantage de sévérité envers la Russie qui, "comme toujours ", manifesta dans l'affaire des partages "plus d'orgueil et de jactance que de pénétration " (Backvis 1933 : 207). Mais derrière ces tares qui seraient constitutives de la Russie, on trouve une fois encore... la Prusse. Et le philologue bruxellois a beau jeu de dénoncer avec Herzen ces " 'Russes allemands', imbus de caporalisme, de morgue prussienne, de manie de l'uniforme et de la parade " (Backvis 1936 : 415).

Mais revenons aux études de l'automne 1939. Étant donné la date de leur publication et quoiqu'elles continssent peu d'allusions à la situation contemporaine - encore que la formule des "trois premiers partages de la Pologne " soit on ne peut plus explicite —, nul ne pouvait les lire sans songer au sort tragique de la république polonaise depuis le $1^{\text {er }}$ septembre ${ }^{25}$. Derrière les menées de l'Ordre teutonique ou les manœuvres de conquête de la Prusse frédéricienne

litudes avec la Russie vont se précisant et le 'caractère latin' des prétendus 'Français de l'Est' devient plus problématique" (Backvis 1935 : 259-260). Plus encore que dans ses publications en français, c'est lorsqu'il s'adresse à des lecteurs polonais que Backvis exprime son slavisme. Ainsi remarquant qu'il y a du Tolstoï et du Dostoïevski chez Żeromski et que ce dernier est probablement « le plus russe de tous les grands écrivains polonais » ([Żeromski] był [...] najbardziej rosyjskim ze wszystkich wielkich pisarzy polskich), le savant belge expliquait semblable particularité par le fait qu'en dépit des influences culturelles et quoiqu'il aspire à être autre chose, un Polonais est avant tout un Slave (" mimo odmienne wpływy kulturalne, mimo jawne dążenie do tego, aby być czymś innym, Polak (jeśli tylko jest szczery i głęboki) jest przede wszystkim Słowianinem ». Backvis 1936b: 312, n. 1). Voir aussi, dans les annés cinquante, Backvis 1954 (à propos de The Kernel of Comparative Slavic Literature de Roman Jakobson).

${ }^{24}$ C'est le slavisant belge qui souligne.

${ }^{25}$ La place de ces articles dans la revue était par ailleurs très significative. "La Pologne et Dantzig " se trouve aussitôt après les pages déjà citées sur "La neutralité belge " dans lesquelles la revue rendait hommage, on l'a vu, aux armées polonaises. Quant à l'étude sur " Les trois premiers partages de la Pologne ", elle fait suite au manifeste dont il est question à la note 22 et à "Une offensive morale ", verte critique signée Le flambeau de la tentative de médiation belgo-hollandaise entre l'Allemagne et les Alliés sur le dos de la Pologne ("C’est [...] avec une douloureuse stupéfaction que nous avons appris, le mardi 7 novembre, par la T.S.F., que notre gouvernement [...] adressait aux belligérants, à l'État agresseur comme à nos amis anglais et français, en oubliant très malheureusement la Pologne, une offre de médiation... Jamais démarche ne parut plus mal préparée, plus inattendue, plus pauvrement motivée " (Le flambeau 1939c : 512). 
secondées par "la complicité insensée de la Russie " (Backvis 1939d : 230) se profilait l'ombre menaçante de l'Allemagne nazie et de son allié soviétique. L'anachronisme est certes flagrant, mais il permet d'ancrer efficacement le passé de la Pologne dans les préoccupations de l'heure. Puisque retracer l'histoire de la vieille civilisation polonaise revient forcément à évoquer les puissances qui travaillèrent à son déclin et à sa destruction, les publications de l'automne 39 devaient causer auprès de leurs premiers lecteurs une impression d'inquiétante familiarité. L'Histoire semblait balbutier et il était impossible de ne pas interpréter à la lumière du présent les événements d'autrefois tels que les rapportait le slavisant belge. Toutefois, aussi tragique fût-il, le passé lui-même laissait quelques raisons d'espérer et, tandis que de nombreuses unités polonaises rejoignaient l'armée française, Backvis concluait son dernier article de 1939 par le souvenir de ces légions qui, "dans l'émigration", se battirent

côte à côte avec les armées de la première République française pour abattre les 'tyrans' " et " avaient raison de chanter dans les plaines de Lombardie : La Pologne n'est pas encore morte. (Backvis 1939f : 543-544)

\section{Un bilan}

Claude Backvis a plus d'une fois déploré l'ignorance de l'Occident à l'endroit des cultures slaves et les " considérations extra-littéraires ", les " raisons idéologiques ou politiques, toujours passagères, éminemment caduques" (Backvis 1946:309) qui, par intermittences, ont suscité l'intérêt éphémère de l'Europe occidentale, romane et germanique, pour le centre et l'est du continent. Qu'elle soit éveillée par les hussites du XV $\mathrm{X}^{\mathrm{e}}$ siècle, les antitrinitaires de la Renaissance ou les artistes polonais du temps de la Grande Émigration, la curiosité n'est que temporaire et s'évanouit avec les circonstances qui l'ont provoquée. Même dans le cas d'un transfert réussi, celui de l'œuvre de Tolstoï dans les dernières décennies du XIX siècle,

les qualités très réelles de l'artiste et de l'individu n'ont été d'abord que le support sous-jacent à l'admiration échevelée que l'on portait aux doctrines du 'philosophe', du sage de Jasnaja-Poljana. (Backvis 1946 : 309)

Tout au long de sa carrière, Backvis s'est employé avec une belle énergie à soustraire l'étude du monde slave - russe et polonais - à la contingence des événements. Aux considérations sur la littérature contemporaine - qu'il n'apprécie pas toujours à sa juste valeur ${ }^{26}$ —, sur les quelques gloires établies en

${ }^{26}$ Ainsi les poètes de Skamander n'auraient été au fond que « des manøeuvres de la poésie et dès aujourd'hui leur œuvre n'est plus qu'un amas de ruines peu intéressantes "! Backvis 1935 : 257. C’est Backvis qui souligne. À vrai dire, le jeune Backvis ne rejette pas les lettres de son temps. Mais 
Occident ${ }^{27}$ ou sur l'actualité politique ${ }^{28}$, il préféra l'examen de moments clés, de périodes de crise au cours desquelles

la collectivité nationale et sociale qui les subit se trouve amenée à envisager rapidement, dans la fièvre du génie et de l'action, à coups d'éclairs, tous les problèmes cruciaux de la race et de l'époque. (Backvis 1936 : 402)

Pour le jeune slavisant - la citation qui précède a un évident parfum d'avantguerre - le règne de Stanislas-Auguste est l'un de ces moments sur lesquels doit se pencher quiconque veut comprendre la Pologne (Backvis 1936 : 403). Avec la maturité, Backvis s'orienta davantage vers la Renaissance et ses prolongements baroques, animé par le même souci de se libérer de la tyrannie du présent.

Dans son œuvre de haute vulgarisation, le slavisant belge n'a pourtant pas toujours évité que les circonstances du moment n’influent sur la représentation du passé de la Pologne. Consciemment ou non, il a mis au point une série de stratégies, de l'analogie à l'anachronisme, visant à éveiller parmi chez ses lecteurs un sentiment de familiarité avec la culture polonaise. On aurait toutefois tort d'exagérer l'importance de tels procédés. Même lorsqu'il est transporté d'enthousiasme par son sujet, Backvis demeure un savant scrupuleux et ses articles sont en général conformes aux faits. Il n'empêche que les stratégies d'acclimatation décrites plus haut introduisent comme un léger effet de distorsion dont l'objectif évident était de faciliter le transfert de connaissances jusque-là peu répandues en Belgique.

L'entreprise fut-elle couronnée de succès ? Poser la question revient à s'interroger sur la réception de ces articles. Or il est souvent malaisé de mesurer l'impact

ses préférences, sans doute influencées par sa formation de philologue et d'historien de la littérature, vont aux œuvres qui font " un bel effort pour refléter les grands problèmes de la société à laquelle elle[s] s'adresse[nt], dans un esprit de réalisme social, de sérieux et de vraie profondeur » et qui constitueront " un jour une source historique de première valeur " (Backvis 1937a : 125). D'où son intérêt pour Maria Dąbrowska, Zofia Nałkowska, Maria Kuncewiczowa ou Helena Boguszewska (Backvis 1939c). En revanche il est passé à côté de Witkiewicz, Gombrowicz ou Schulz.

${ }^{27}$ Il n'a que dédain pour Sienkiewicz qu'il considère comme "l'auteur polonais le plus vulgaire, celui qui a flatté de la façon la plus éhontée les mauvaises passions de l'âme polonaise ". Backvis 1937a : 130. Voir aussi Backvis 1946: 325.

${ }^{28}$ Son seul article connu sur un sujet politique est un long compte rendu élogieux de l'ouvrage qu'Anatole Mühlstein venait de consacrer au Maréchal Pitsudski (Paris, Plon, 1939) et dans lequel le chef d'État polonais était décrit comme un démocrate et un libéral (Backvis 1939b). Notons qu'après la guerre, Backvis, tout en publiant dans des revues de l'émigration (les londoniennes Wiadomości par exemple), semble avoir entretenu d'assez bons rapports avec le nouveau régime. À la fin de l'année 1955, il se rendit en Pologne avec une délégation belge composée, entre autres, des écrivains Franz Hellens et Robert Vivier à l'occasion du centenaire de la mort de Mickiewicz (Le Soir, 4 janvier 1956). Il publia également quelques articles en Pologne populaire (notamment dans Pamiętnik Literacki et Pamiętnik Teatralny). 
qu'un texte a pu avoir sur le public auquel on le destinait. Dans le cas présent, nous disposons cependant d'éléments qui laissent entrevoir que les travaux de haute vulgarisation du slavisant belge ont probablement bénéficié d'une certaine audience. Dans les années trente, la Revue de l'Université de Bruxelles était tirée à trois mille exemplaires et distribuée gratuitement aux anciens étudiants de l'ULB (De Reul 1934 : 204). Quant au Flambeau, publication bien implantée dans le paysage intellectuel belge de l'entre-deux-guerres, ses livraisons faisaient régulièrement l'objet d'un compte rendu dans des quotidiens nationaux comme L'Indépendance belge et $L e$ Soir, ce qui leur assurait une indéniable publicité. Par ailleurs, sur une décision du ministre libéral de l'Instruction publique Julius Hoste, la revue, avec trois autres périodiques - dont la très catholique Revue générale et deux titres flamands - était depuis 1936 envoyée « dans un certain nombre d'écoles, à raison [...] des articles à caractère général qui peuvent intéresser les professeurs et les tenir au courant des mouvements des idées " (Le flambeau 1939a : 476). Il n'est donc pas hasardeux de penser que Backvis a été lu.

On peut cependant douter que son action de médiateur ait produit, sur le moyen et le long terme, les résultats escomptés. Backvis contribua certes à alimenter l'intérêt que, dans les années vingt et trente, les vainqueurs de la Grande Guerre, souvent poussés par des considérations géopolitiques, éprouvaient pour les nouveaux États slaves de l'Europe centrale. Après 1945, cet attrait diminua considérablement, la Guerre froide ayant peu à peu converti la région en une "Europe de l'Est " qui, vue de l'Occident, semblait définitivement arrimée à l'Union soviétique. Un coup d'œil aux sommaires du Flambeau permet de mesurer l'étendue de cette désaffection. Si, jusqu'en 1940, la revue consacrait régulièrement des pages à la culture polonaise, le bilan de l'après-guerre — le titre cessera de paraître en 1976 - est bien maigre : quatre contributions seulement, dont trois signées de Claude Backvis. Ce dernier déplorait, on l'a vu, que l'Occident s'attachât aux nations slaves pour des raisons tenant davantage au hasard des circonstances qu’à un désir réel et désintéressé de connaissance. Cependant son activité de médiateur fut loin d'être indépendante du contexte qui l'a vue naître. Une fois que les circonstances eurent changé et que la Pologne, transformée en satellite soviétique, fut redevenue invisible au regard de l'Occident, Backvis se détourna peu à peu de son travail de médiation et privilégia les publications savantes.

Son enseignement bruxellois bénéficia cependant à des générations de polonisants, parmi lesquels on retiendra surtout Marian Pankowski et Alain Van Crugten qui, tous deux, poursuivirent, à des degrés divers, l'œuvre de médiation de leur maître. Plus connu comme écrivain que comme traducteur, le premier 
a néanmoins laissé une Anthologie de la poésie polonaise dont il a été question plus haut $^{29}$. Le second a signé, entre autres, d'innombrables versions d'auteurs polonais, de Witkiewicz — dont il fut l'un des principaux introducteurs en langue française - à Schulz, de Różewicz à Mrożek (Van Crugten 1999) ${ }^{30}$. Tout ceci suffit indéniablement à assurer à Backvis une place importante dans l'histoire culturelle de la Belgique du XX siècle.

\section{BIBLIOGRAPHIE}

\section{Archives}

Archives de l'ULB, dossier professionnel « Backvis, Claude» 1. P. 925.

Archives de l'ULB, dossier professionnel « Eck, Alexandre »1. P. 117.

Archives de l’ULB, dossier professionnel «Lednicki, Venceslas » 1. P. 1006.

\section{Littérature primaire et secondaire}

Backvis Claude. 1932. "Jules Slowacki. La Pologne romantique ". Le flambeau, XV, 7 (juillet). Pp. 30-58.

Backvis Claude. 1933. "La tragédie des Potocki ». Le monde slave, X (n.s.), t. IV, 11 (novembre). Pp. 194-226.

Backvis Claude. 1935a. "Les tendances de la littérature polonaise (1932-1933). Le monde slave, I, 2. Pp. 238-260.

Backvis Claude. 1935b. "Kilka uwag o Trembeckim » [Quelques remarques sur Trembecki]. Przegląd Wspótczesny, XIV, 6 (juin). Pp. 303-330.

Backvis Claude. 1936a. "L'évolution des idées en Russie au milieu du XIX siècle. Remarques préliminaires. Aux origines de la pensée russe ". Le flambeau, XIX, 4 (avril). Pp. 401-429.

Backvis Klaudiusz. 1936b. "Myśli cudzoziemca o Żeromskim » [Réflexions d'un étranger sur Żeromski]. Przekład Wiktora Jakubowskiego [traduction de Wiktor Jakubowski]. Przegląd Wspótczesny, XV, 9 (septembre). Pp. 305-323.

Backvis Claude. 1937a. "Les tendances de la littérature polonaise pendant les années 1934-1935. Le monde slave, I, 1. Pp. 122-137.

${ }^{29}$ Pankowski 1961. D’après son auteur, cette anthologie naquit des carences de Backvis traducteur. «Lorsque je travaillais à l'ULB, Claude Backvis parlait de la poésie polonaise avec énormément de chaleur et d'émotion [...]. Mais quand il fallait proposer une strophe, la traduction n'était pas à la hauteur des poèmes cités. [...]. Je me suis dit alors qu'il fallait que les étudiants puissent lire cette poésie chez eux. J'ai donc fait un choix de poèmes, parmi ceux qui me plaisaient personnellement, du XVe siècle jusqu’à Miłosz, et je les ai traduits ». Walczak et Lambert 2008. Publié à compte d'auteur, l'ouvrage a été tiré à mille trente exemplaires.

${ }^{30}$ Slavisant et germaniste, Alain Van Crugten a également traduit du russe, du tchèque, de l'anglais et du néerlandais. 
Backvis Claude. 1937b. Un grand poète polonais du XVIII siècle : Stanislas Trembecki : l'étrange carrière de sa vie et sa grandeur. Paris : Bibliothèque polonaise (Centre d'études polonaises de Paris).

Backvis Klaudiusz. 1939a. " Jak doszedłem do studiów nad literaturą polską i nad Trembeckim »[Comment j'en suis arrivé à étudier la littérature polonaise et Trembecki]. Przekład Wiktora Jakubowskiego [traduction de Wiktor Jakubowski]. Przeglad Wspótczesny, XVIII, 1 (janvier). Pp. 145-152.

Backvis Claude. 1939b. "Joseph Pilsudski ». Le flambeau, XXII, 5 (mai). Pp. 503-513.

Backvis Claude. 1939c. "Quelques romans de femmes en Pologne». Bulletin des anciens étudiants de l'Université libre de Bruxelles, 129 (juin) et 130 (juillet). Pp. 29-32 et 19-22.

Backvis Claude. 1939d. "La Pologne et Dantzig ». Le flambeau, XXII, 9 (septembre). Pp. 229-243.

Backvis Claude. 1939e. "L'ancienne république polonaise ". Le flambeau, XXII, 10 (octobre). Pp. 395-408.

Backvis Claude. 1939f. "Les trois premiers partages de la Pologne ». Le flambeau, XXII, 11 (novembre). Pp. 518-544.

Backvis Claude. 1949 (1 $1^{\text {ère }}$ éd. 1946). "Les littératures slaves ». Pierre Wigny (dir.). La bibliothèque de l’honnête homme. Bruxelles : Goemaere. Pp. 309-326.

Backvis Claude. 1952. Le dramaturge Stanislas Wyspiański (1869-1907). Paris : Presses Universitaires de France (Université libre de Bruxelles. Travaux de la Faculté de Philosophie et Lettres, XIV).

Backvis Claude. 1954. "Harvardzkie studia słowiańskie » [Études slaves de Harvard]. Wiadomości, 14. P. 418.

Backvis Claude. 1956. "Pour le centenaire de Mickiewicz ". Le flambeau. XXXIX, 3 (mai-juin). Pp. 272-287.

Backvis Claude. 1960. "Wladislaw Stanislaw Reymont ». Wladyslaw Stanislaw Reymont. De boeren. Eeste deel. Nederlands van Hans C.M. Fens. Met een inleiding over auteur en werk door prof. dr. Claude Backvis. Hasselt : Uitgeverij Heideland ( «Pantheon der winnaars van de Nobelprijs voor literatuur»). Pp. 7-41

Backvis Claude. 1995. Panorama de la poésie polonaise à l'âge baroque. Bruxelles : Académie royale de Belgique (Mémoires de la Classe des Lettres).

Béghin Laurent. 2014. "La revue Le flambeau et les littératures slaves ". Textyles, 45. Pp. 105-122.

Béghin Laurent. 2017. "Wacław Lednicki et les débuts de la slavistique universitaire belge ". Svetlana Čečović, Hubert Roland (éd.), Réception, transferts, images. Phénomènes de circulation littéraire entre la Belgique, la France et la Russie 1870-1940. Bruxelles/ Francfort-sur-le-Main : Peter Lang (à paraître).

Bernard Antonia. 2002. "Le monde slave, première revue française consacrée aux pays slaves ". Revue des études slaves, 74, 2-3. Pp. 397-409. 
Bingen Jean, Blankoff Jean. 1999. "Claude Backvis ». Annuaire de l'Académie royale de Belgique. Pp. 67-85.

Borowski Andrzej. 2001. "Claude Backvis (1910-1998). Organon, 28-30. Pp. 5-18.

De Reul Paul. 1934. "Revue de l'Université de Bruxelles ». 1909-1934. L'Université de Bruxelles. Bruxelles : Imprimerie Scripta. Pp. 203-208.

Despy-Meyer Andrée, Dierkens Alain, Scheeling Frank, éd. 1991. 21.11. 1941. L'Université libre de Bruxelles ferme ses portes, Bruxelles : Archives de l'ULB.

Krasinski Sigismond [Krasiński Zygmunt]. 1948. La comédie non-divine. Introduction et traduction de Claude Backvis. Liège : Éditions Solédi (Bibliothèque internationale, 5).

Kuncewiczowa Maria. 1945. L'étrangère. Traduction par Claude Backvis. Paris : Corréa.

Lednicki Wacław. 1932. "Wspomnienia brukselskie ". Przegląd wspótczesny. XI, 4 (avril). Pp. 182-207.

Lednicki Wactaw. 1971. Reminiscences. The Adventures of a Modern Gil Blas during the Last War, with a prefatory note by C.H. van Schooneveld. La Haye-Paris : Mouton.

Le flambeau. 1939a. "Pro domo nostra ". Le flambeau. XXII, 4 (avril). Pp. 474-480.

Le flambeau. 1939b. "La neutralité belge ". Le flambeau. XXII, 9 (septembre). Pp. 225-228.

Le flambeau. 1939c. "Une offensive morale ". Le flambeau. XXII, 11 (novembre). Pp. 509-517.

Nowicka-Jeżowa Alina. 1999. "Claude Backvis (24 kwietnia 1910 - 16 maja 1998) ». Pamiętnik Literacki, 90/3. Pp. 237-244.

Pankowski Marian. 1961. Anthologie de la poésie polonaise du XVe siècle au XXe siècle. Introduction de Claude Backvis. Aalter : André De Rache.

Université libre de Bruxelles. 1937. Institut de philologie et d'histoire orientales et slaves. Programme des cours. Bruxelles : Établissements Émile Bruylant.

Van Crugten Alain. 1999. "Dis-moi qui tu traduis... ". Cahiers internationaux de symbolisme. 92-93-94. Pp. 177-212.

Walczak Dorota, Lambert Jeremy. 2008. « Entretien avec Marian Pankowski ». Slavica bruxellensia [en ligne], 1, mis en ligne le 15 octobre 2008, URL : http://slavica.revues. $\operatorname{org} / 236[26 / 12 / 2016]$. 


\title{
TO GO TO POLAND WAS TO GO TO THE LIGHT. CLAUDE BACKVIS AND THE MEDIATION OF POLISH CULTURE IN FRENCH-SPEAKING BELGIUM (1930-1960)
}

\author{
(summary)
}

The figure of Claude Backvis (1910-1998) is well known to Polish scholars. His research is still valued today, especially his seminal work on the Baroque period. However, there is an aspect of Claude Backvis's activity that has been neglected: his work as a popularizer and disseminator of Polish culture to a non-specialized audience. For many years, especially before the Second World War, Backvis regularly published articles on Poland and its literature in various Belgian French-language magazines. He also published a few translations of Polish authors such as Zygmunt Krasiński and Maria Kuncewiczowa.

Which strategies of adaptation (or acculturation) did Backvis, a rara avis in a country practically devoid of any tradition in the field of Polish studies, adopt to present Poland, especially its history and its literature, to readers little acquainted with Polish affairs? How did the period (particularly the years before the war) and the places of mediation (generally linked to the spiritual climate of the Universite libre de Bruxelles) influence the mediation itself? These are the questions that this article attempts to answer

\section{KEYWORD}

Backvis Claude; Belgium; Cultural transfers; Interwar; Lednicki Wacław; Poland; Slavic philology; Université libre de Bruxelles 


\section{PORÓWNANIA I KONTEKSTY. \\ Z ZAGADNIEŃ KOMPARATYSTYKI}





\section{ŻYCIE I PISANIE (DLA) WSPÓLNOTY: KÄTHE SCHIRMACHER I STEFANIA LAUDYN-CHRZANOWSKA MIĘDZY FEMINIZMEM A NACJONALIZMEM}

\section{SŁOWA KLUCZOWE}

jednostka i wspólnota; narracja; wczesny feminizm; nacjonalizm polski i niemiecki w XX wieku; polityczne przesilenie; Stefania Laudyn-Chrzanowska; Käthe Schirmacher

Na szczególne znaczenie aktu opowiadania dla wspólnot zwrócili trafnie uwagę Benedict Anderson (1983) oraz Homi Bhabha (1990). Przywołani badacze skupiają się wprawdzie na narracyjnej reprezentacji grup narodowych, lecz moim zdaniem ich ustalenia z powodzeniem dadzą się odnieść do ruchu kobiecego. Można się, oczywiście, spierać, na ile ruch ten był wspólnotą w rozumieniu Ferdinanda Tönniesa (1887), autora fundamentalnego rozróżnienia między wspólnotą (Gemeinschaft) a stowarzyszeniem (Gesellschaft). Skłonna jestem jednak uznać go za twór zdecydowanie bliższy wspólnocie, podobnie jak w wypadku narodu, podstawą istnienia ruchu kobiecego nie są bowiem umowa, negocjacje i decyzja o przystąpieniu lub byciu „przyjętym” do danego grona, ale więź uznawana za naturalną, gdyż ugruntowana na czymś, co pozostaje poza przedmiotem wyboru jednostki; więź wypływająca z przekonania o łączącym grupę „realnym i organicznym życiu" (Tönnies 1922: 3-4). Kobiety i naród są przy tym z jednej strony wspólnotami głęboko ze sobą związanymi (żaden naród nie istnieje wszak bez kobiet), zyskującymi samoświadomość w toku analogicznych procesów modernizacyjnych, z drugiej — konkurencyjnymi wobec siebie ${ }^{1}$.

Monika Bednarczuk — dr hab., Seminar für Slavistik, Ruhr-Universität Bochum, Universitätsstr. 150, 44789 Bochum, Niemcy, Raum GB 8/57; e-mail: monika.bednarczuk@rub.de

1 O ile niektórzy zwolennicy prymatu etnosu wspierali równouprawnienie płci, inni wyolbrzymiali ad absurdum myśl o emancypacji kobiet, kojarząc ze skrajną lewicą na przykład figury 
W centrum moich refleksji stoją postaci, które włączyły się w praktyki zmierzające do wzmocnienia tożsamości obu tych wspólnot. Zaangażowanie kobiet w nurt feministyczny wyjaśniać można chęcią przezwyciężenia poczucia jednostkowej alienacji i stworzenia przeciwwagi dla dominującej patriarchalnej kultury. Tendencje te przyspieszała świadomość pokrewieństwa doświadczeń społeczno-historycznych warunkowanych właśnie płcią oraz przecinania się tożsamości indywidualnej ze zbiorową (Rowbotham 1973; Friedman 1998). Z podobnych powodów kobiety popierały już wcześniej stronnictwa nacjonalistyczne. Różnica polegała na tym, że w mentalnym schemacie samoobrony i walki miejsce rywala lub wręcz opresora zajmowały w jednym wypadku narody i organizacje uznawane za nieprzyjazne wobec danej społeczności etnicznej, w drugim - androcentryczna kultura. Potrzebę przynależności do większej zbiorowości trudno przecenić. Hertha D. Sweet Wong celnie akcentuje w tym kontekście relacyjny charakter podmiotowości dostrzegalny choćby $\mathrm{w}$ autobiografiach rdzennych mieszkanek Ameryki, wedle których (nadmierny) indywidualizm godzi w wartości scalające grupę, konstytutywne dla niej (Wong 1998).

Biografia i życie Schirmacher oraz Laudyn także świetnie ilustrują tak motywowaną relacyjność. Obie działaczki odeszły w pewnym momencie, właściwie u szczytu swojej popularności, od ideałów wczesnego feminizmu, aby stanąć w obronie zagrożonej w ich mniemaniu wspólnoty narodowej. Jednocześnie żadna nie uważała się za zdrajczynię. W ich świadomości obecne były zarówno „sprawa narodowa”, jak i „kobieca”. Jedynie waga przechylała się gwałtowniej na jedną ze stron, zgodnie z obserwacją Wong, która akcentuje różnorodność i wielowarstwowość zależności spajających jednostkę i wspólnotę oraz nieuchronnie związaną z tymi uwikłaniami ewolucję indywidualnej tożsamości (Wong 1998: 172). Warto zastanowić się nad światopoglądowymi zmaganiami zachodzącymi w świadomości omawianych tutaj postaci, aby wniknąć w kontekst, w jakim dokonują się przewartościowania ideowe, i zobaczyć jak głęboko prywatne przenika się z publicznym, a jednostkowe ze zbiorowym; jak jedno przechodzić może $\mathrm{w}$ drugie.

Käthe Schirmacher (1863-1930) po studiach w Paryżu i Zurychu rozpoczęła karierę dziennikarską i literacką, podróżując po Europie i Ameryce. Wszędzie agitowała na rzecz praw politycznych kobiet, dopóki na kilka lat przed I wojną światową uwagi jej nie przykuły dwa żywotne — w jej oczach — problemy: „słabość” Niemców wobec Francji i Anglii oraz dominacja „socjalistyczno-żydowskiej gwardii” w ruchu kobiecym (Schirmacher 1921: 50). Później

rozpasanych komunistek. Część aktywistek kobiecych z kolei żywiła nieufność wobec narodowców. Por. Kurczewska 1999. O antybolszewizmie i antyfeminizmie w XX wieku Bednarczuk 2012: 41-47, 182-217, 236-247. 
występowała już wyłącznie z pozycji nacjonalistycznych, czy to jako publicystka, czy jako posłanka do Reichstagu (por. Walzer 1991). Z kolei Stefania Laudyn-Chrzanowska² (1872-1942) to pisarka i działaczka, która z Rosji oraz Galicji, gdzie dała się poznać jako orędowniczka słowiańskiego porozumienia kobiet, wyjechała do Stanów Zjednoczonych. Tam, pełniąc funkcję redaktorki „Głosu Kobiet”, szerzyła nowoczesne poglądy na temat kobiet i kształcenia młodzieży oraz inicjowała zakładanie samopomocowych towarzystw ubezpieczeniowych. W trakcie Wielkiej Wojny narastało w niej jednak coraz silniej przeświadczenie, że Polska padła ofiarą wrogiej jej ludności żydowskiej, oraz że feminizm zawiódł kobiety. Z tych powodów poparła obóz młodoendecki (Majewski 2001; Bednarczuk 2012: 259-341).

\section{Sprzężenie życia i narracji}

Punktem wyjścia dla moich uwag są dwa założenia. Po pierwsze, sfera życia prywatnego i publicznego są ze sobą nierozerwalnie sprzężone, co manifestuje się zwłaszcza w obliczu kryzysów ideowych oraz konfliktów militarnych. Po drugie, tożsamość i interakcje (językowe, kulturowe) z innymi wzajemnie się warunkują, co z kolei odsyła do - ważkich dla omawianych dalej postaw oraz tekstów — zjawisk, jakimi są konkurencja międzyetniczna oraz skłonność do częściowego lub całkowitego utożsamiania się ze wspólnotą. Z tych względów uzasadnione wydaje mi się zestawienie życia z opowieścią (o nim i o wspólnocie), a także spojrzenie na pewne narracje i historie indywidualne jako na metonimie narracji lub historii określonej grupy ${ }^{3}$. Za pośrednictwem analizy życiorysów, egodokumentów, publicystyki oraz utworów literackich Schirmacher i Laudyn będę rekonstruować ich wkład w rozwój wspólnot wyobrażonych, na których rzecz pracowały, odtwarzać narracje o tych poczynaniach, wreszcie śledzić proces mentalnej przemiany, którego konsekwencją było „polityczne przesilenie” (Schirmacher 1921: 40).

Do nierozdzielania egzystencji od tekstu zainspirowała mnie Carolyn G. Heilbrun, która wyróżniła cztery sposoby „pisania” kobiecego życia (Heilbrun 1988: 11). Wedle Heilbrun kobieta może to po pierwsze uczynić osobiście, posługując się w tym celu jednym z gatunków autobiograficznych ${ }^{4}$ lub fikcjonal-

2 Publicystka różnie podpisywała swoje utwory. Dla jednolitości wywodu posługuję się nazwiskiem Laudyn.

3 O „auto/biografii narodu” mówi Johanna Gehmacher (2000), która zastanawia się nad specyfiką kobiecej autobiografii politycznej, opierając się na wspomnieniach i wybranych artykułach Schirmacher.

4 Jedynie Käthe Schirmacher pozostawiła autobiografię sensu stricto (dokładniej wspomnienia). 
nych5 , po drugie, może to zrobić ktoś inny, przygotowując jej biografię, wreszcie samo przeżywanie własnej historii jest jej swoistym „(za)pis(yw)aniem”. Nieortodoksyjny pomysł Heilbrun otwiera szersze pole dla rozpoznań niż klasyczne studia poświęcone autobiografii. Rekonstrukcja „pośrednia”, do jakiej zmierzam, wydaje się zresztą konieczna, jeśli chcemy wychwycić podobieństwa paradygmatów myślowych, doświadczeń oraz wzorców zachowań u Schirmacher i Laudyn, a to przede wszystkim z powodu asymetrii w zakresie zachowanych materiałów ${ }^{6}$.

Jak prześledzić (r)ewolucję światopoglądu w wypowiedziach auto/biograficznych, utworach fikcjonalnych, dziennikarskich oraz życiorysach? Jedną z dróg jest lektura równoległa pod kątem znaczących motywów. Kathryn A. Manzo, poddawszy namysłowi „głębsze struktury” dyskursów ideologicznych, uwypukliła kilka powtarzających się schematów wyobrażeniowych związanych z archetypami mitologicznymi i biblijnymi, wśród nich: narodziny (przebudzenie), exodus oraz nieśmiertelność dzięki ofierze (Manzo 1996: 30-47). Bez specjalnego nadużycia można do nich dodać „dojrzewanie”. W swoich refleksjach Manzo skupia się wprawdzie na nacjonalizmie, ale wymienionymi motywami, po odpowiedniej obróbce, posiłkują się również inne dyskursy, konstruując opowieści o sobie. Kilka wątków znamiennych dla polskich — i nie tylko - emancypantek przełomu XIX i XX wieku wyszczególniły z kolei Natali Stegmann oraz Dietlind Hüchtker. Stegmann eksponuje „pożegnanie z 'idealnym światem’ ojców, czyli opuszczenie domu bądź śmierć rodzica, oraz wyjazd na studia, oznaczający nowe znajomości, ale i poważne przeszkody (Stegmann 2000: 112-132). Hüchtker wśród „wędrownych toposów" wylicza sprzeciw wobec społecznego upośledzenia kobiet (znany doskonale z Marty Elizy Orzeszkowej) oraz czekanie (na męża, na możność uczenia się i zarobkowania, na samodzielność), czyli wymuszoną bezczynność (Hüchtker 2009: 173-181).

Sądzę, że wszystkie zreferowane wyżej propozycje odwołują się w istocie do pojemnych metafor „narodzin”, względnie „przebudzenia”, otrzą́nięcia się ze „snu” lub „wyjścia z niewoli”. Ponadto przyjrzeć się warto literackim strate-

5 We wstępie do opowiadań Galeria obrazów z krainy dolara, Stefania Laudyn zastrzegała: „Starałam się przede wszystkim o ich życiową wierność [...] pisząca brała je [tj. wypadki] przeważnie ze zdarzeń życia, na które sama bezpośrednio patrzyła" (Laudyn 1920: 5). Natomiast Schirmacher (1921: 37-38) o pierwszych próbach prozatorskich mówi, iż zawierają to, czego sama doświadczyła („Selbsterlebtes”) (Schirmacher 1921: 37-38). Por. charakterystykę Phil w Die Libertad (Schirmacher 1891: 16) oraz autocharakterystykę pisarki (Schirmacher 1921: 19). Wszystkie tłumaczenia z utworów literackich i publicystycznych Käthe Schirmacher - M.B.

${ }^{6}$ Laudyn-Chrzanowska pozostawiła ich nieporównywalnie mniej niż Schirmacher, głównie w formie rozproszonych wypowiedzi prasowych, brak też dostępu do jej osobistych zapisów. Schirmacher wydała zawczasu własne wspomnienia i liczne publikacje. Poza tym u każdej z nich dominują inne gatunki. 
giom prezentacji „obcych” i „swoich” oraz personifikacjom wspólnoty (Manzo 1996: 60). W nawiązaniu do wskazanych motywów prześledzę zatem życiorysy oraz narracje Schirmacher i Laudyn, z których wyłuskiwać będę paralele, sploty tudzież przejścia między indywidualnym a wspólnotowym, przyglądając się zarazem ich przyczynom oraz rezultatom.

\section{Życie i pisanie (dla) feminizmu}

Od jakiego aktu, w jakiej chwili rozpoczyna się emancypacyjna auto/biografia? Ani Schirmacher, ani Laudyn nie wskazują przełomowego momentu. Käthe Schirmacher zaprzecza nawet istnieniu dyskryminacji kobiet w swoim rodzinnym, mieszczańsko-kupieckim środowisku, lecz potwierdza, iż na poły świadomie stykała się ze zjawiskiem nierówności, przede wszystkim w życiu publicznym. Pierwsze przebudzenie kojarzy z duchem czasu, z zasłyszanymi uwagami o ucisku „w świecie”; z tego względu, podobno już jako dwunastolatka, w czasie lokalnych wyborów politycznych zaczęła domagać się praw dla kobiet i bawić w składanie kart do głosowania (Schirmacher 1921: 8). Także z rozrzuconych uwag o Stefanii Laudyn wnioskować można, że impulsem do aktywności emancypacyjnej była obserwacja otoczenia: bliższego lub dalszego.

Obie autorki od młodości cechuje idealizm i żądza poznania. Schirmacher mówi wprost o „faustyczny[m] pęd[zie] do odgadnięcia zagadki świata, zmierzenia się z przekazaną wiarą i własnym myśleniem, tak męczący[m], że dochodziłam dosłownie do kresu rozumu" (Schirmacher 1921: 10). Ich niezależność dawała o sobie znać od wieku szkolnego. Schirmacher rysuje siebie jako dziecko przekorne i humorzaste. Laudyn (z domu Borowska) wcześnie wchodziła w konflikty z rodzicami oraz władzami szkolnymi (Majewski 2001: 492). Niemiecka działaczka akcentuje ponadto pozytywną rolę ojca, z którym dyskutowała o polityce, i szwagra, który opłacił jej pobyt w Paryżu. Stawianie siebie w roli „spadkobierczyń ojców” było zresztą typowe dla feministek przełomu XIX i XX wieku (Stegmann 2000: 114). O Laudyn wiemy jedynie, iż przebywając w Moskwie uczęszczała na uniwersytet $\mathrm{i}$, wraz z mężem, byłym powstańcem styczniowym, którego czciła za patriotyzm, brała udział w charytatywnych przedsięwzięciach polskiej diaspory. W jakiejś mierze można chyba uznać starszego od żony Kazimierza Laudyna i hojnego szwagra Käthe Schirmacher za odpowiedniki wspierającego, akceptującego ojca ${ }^{7}$. Nie znaczy to, że milczano na temat matek i nauczy-

7 Szwagrowi zadedykowała Schirmacher opowiadanie Die Libertad. Pierwszy mąż Stefanii Laudyn pojawia się na kartach jej utworów. Złożyła hołd jemu i jego towarzyszom z zesłania w dramacie Umęczone orty 63 roku (1925). Drugiemu poświęci jedną z późniejszych prac (Laudyn-Chrzanowska 1929: 2). 
cielek. Niemniej jednak, na pierwszym planie narracji o domu stoją mężczyźni (z pokoleniem dziadków włącznie). Kobiety zastąpią ich dopiero w (auto)narracji o dorastaniu jako nauczycielki, przyjaciółki, siostry. Cecha ta jest o tyle znacząca, że nakazuje ostrożność wobec tezy o szczególnej randze ojców: „nad-ojców” (Überväter) w biografiach i autobiografiach nacjonalistek. Tezę taką wysuwa chociażby Ortrun Niethammer stwierdzając, iż (nad-) ojcowie wprowadzają córki w świat kultury, pisma, idei, podczas gdy matki oraz macochy przedstawiane są jako postaci problematyczne, często stylizowane na nadmiernie kobiece (Niethammer 1996: 103, 105), tymczasem w świetle świadectw przytaczanych przez niemieckie badaczki wschodnioeuropejskiego ruchu kobiecego zjawisko to dotyczy w niemałej mierze również emancypantek, a wiązać je wypada zapewne z patriarchalnym kształtem kultury XIX wieku, z której zarówno nacjonalistki, jak feministki się wywodziły.

Jak przebiegały „lata nauki” i „lata wędrówki”? O własnej edukacji pisze eksplicytnie tylko Schirmacher, relacjonując spotkania z profesorami — znów, siłą rzeczy, starszymi i stojącymi wyżej od niej w hierarchii społecznej mężczyznami - w Paryżu i Zurychu. Szczególnie ciepło wspomina życzliwość Richarda Avenariusa ${ }^{9}$. Przy tym działaczka równolegle do kształcenia się na akademii i w bibliotekach zdobywa wiedzę o ulicy, kabarecie, półświatku oraz rozmaitych organizacjach politycznych (od anarchistów po feministki), chcąc naocznie się przekonać, jakie choroby trawią ludzkość i jakie remedia proponują poszczególne stronnictwa (Schirmacher 1921: 12-26; 1900). W identyczne doświadczenia, łącznie z walką o przetrwanie za niewielkie środki i pierwszymi męskimi znajomościami (z zasady nieudanymi), wyposaża bohaterki utworów Die Libertad ${ }^{10}$ (1891) oraz Halb (1893).

Jako kobiety i reprezentantki aktywnej, feministycznej części tej wspólnoty płci Schirmacher oraz Laudyn nauczyły się wytrwałości i gotowości podejmowania ryzyka mimo „nieskończenie wielu chwil smutku i słabości” (Schirmacher 1893: 15). Entuzjazm i upór to leitmotywy omawianych życiorysów oraz auto/ narracji ${ }^{11}$. Schirmacher (1891: 23, 27) stosuje metafory „herkulesowej pracy” i „płomieni”, a charaktery dwóch przyjaciółek z Die Libertad porównuje do „ognistej” i „nasyconej czerwieni”. Laudyn zakłada w 1907 roku w Moskwie Związek Kobiet Polskich, żeby edukować robotników, należy do Związku Równoupraw-

${ }^{8}$ Tej formuły Goethego używa sama Schirmacher w autobiografii Flammen (Ptomienie).

9 Zadedykowała mu biografię Woltera (1898), która powstała właśnie z inspiracji profesora.

${ }^{10}$ Pomimo podtytułu „Novelle” cechy strukturalne przemawiają za zakwalifikowaniem go jako opowiadanie.

${ }^{11}$ Ważny wydaje się w tym kontekście fakt, że dysertacja Schirmacher (1896) dotyczyła Théophile de Viau, poety, libertyna prześladowanego przez Kościół, konwertyty. Wkrótce potem pisarka ukończyła biografię Woltera. 
nienia Kobiet we Lwowie, wystosowuje list otwarty do Lwa Tołstoja i komentuje sytuację Polaków w piśmie „Ruš”. Później nada jednej z bohaterek przydomek „Zbuntowana” (Laudyn 1920: 154). Sama też odważnie bronić będzie swoich racji (Radzilowski 1981: 177).

Jednym z pierwszych zagadnień, z jakimi przyszło się zmierzyć emancypantkom, były podwójne standardy moralne i wiązana $\mathrm{z}$ nimi prostytucja. Siłowały się z tymi problemami w praktyce i w twórczości. Die Libertad, tekst dotykający tej kwestii, „wzbudził — zdaniem autorki — potężne zamieszanie [...]. Było to pierwsze podejście do muru spraw, o których się nie mówi” (Schirmacher 1921: 24). Sprawa ta powracać będzie w jej publicystyce (obrazy „pariasów miłości” w szkicach paryskich) (Schirmacher 1900: 286, 340) oraz w Halb, której protagonistka omal nie stoczy się na moralne dno. Laudyn także chce przeciwdziałać podwójnym standardom moralności. W Ameryce zajmie się „białym niewolnictwem”, obarczając winą za nie między innymi Żydów (Laudyn 1917: 64). Zaangażowany ideowo jest jednak już jej wczesny dramat Zmarnowane życie (1895) traktujący o niedobranym, nieszczęśliwym małżeństwie.

Proces konfrontacji ze światem to podejmowanie kolejnych wyzwań: Schirmacher i Laudyn przystępują do zrzeszeń, powołują nowe, podróżują. Schirmacher naucza w Liverpoolu i w Prusach, broni doktoratu, udziela się jako prozaiczka oraz dziennikarka na łamach licznych czasopism. Laudyn przemieszcza się między Rosją a Galicją, debiutuje jako literatka oraz propagatorka słowiańskiego porozumienia. Granice między narodami jawią się wówczas obu jako drugorzędne. Po Międzynarodowym Kongresie Kobiet w Chicago w 1893 roku Schirmacher marzy o scaleniu ruchów narodowych w jeden potężny nurt oraz o uzmysłowieniu mężczyznom, iż sami „nie zdołają rządzić światem” (Schirmacher 1897: 336).

Obie aktywistki wierzą, że w solidarności kobiet skrywa się potencjał zdolny przebudować stary ład i tak też kreują swoje światy literackie. Bohaterki Die Libertad wspomagają się wzajemnie, sukcesywnie poszerzając swoje pole oddziaływania. Charlotte zostaje adwokatem ubogich oraz kobiet. Sama Schirmacher, podsumowując swe agitacyjne przemówienia, porównuje się do rolnika:

[...] rozorałam tę starą część ziemi i siałam niemiecką ręką [...] międzynarodowe ziarno. Bo sprawy kobiet [...] były w swojej istocie, choć nie w natężeniu, [...] wszędzie te same (Schirmacher 1921: 34).

Laudyn, za przykładem Orzeszkowej i jej Listu otwartego do kobiet niemieckich (1887), identyfikuje sprawę kobiecą z narodową. W imieniu Polek, grupy dyskryminowanej podwójnie, bo i z racji płci i przynależności etnicznej, apeluje 
do Rosjanek o włączenie się w politykę, wywarcie pozytywnego wpływu na mężczyzn oraz ulżenie doli polskich rodzin:

[...] kobieto rosyjska [...] Polska dla ciebie [...] kraj [...] najbliższy ze wszystkich [...]. I takie przekonania nie tylko powinnyście mieć same, lecz i rzucić nowy twórczy siew w duszę dzieci waszych, dać im świeży, nowy światopogląd. (Laudyn 1908: 40-41)

W auto/biografię feminizmu wpisany jest pobyt w Stanach Zjednoczonych, kojarzonych z wolnością, luźniejszym gorsetem obyczajowym dla kobiet, szansą na rozwinięcie skrzydeł (Schirmacher 1897: 336; 1893: 32-36). Wystarczy przywołać ikony ruchu kobiecego: Abby Kelly, Lucretię Moth czy Elizabeth Cady Stanton (Schirmacher 1909: 3-5). Jedna z bohaterek Die Libertad, rekapitulując swoje początki za oceanem, wyznaje: „płeć nie powodowała tam żadnych trudności; z przeszkód przezwyciężyć musiałam tylko te, które stoją na drodze każdego nowicjusza" (Schirmacher 1891: 8). W Halb ucieleśnieniem odważnej - acz nie dość zdecydowanej — amerykańskiej kobiecości jest Ethel Rodd, która w trakcie studiów dorasta mentalnie i wypowiada posłuszeństwo konserwatywnemu narzeczonemu. Postać ambitnej kobiety, która szuka w Ameryce lepszego życia, żeński odpowiednik self-made mana, pojawia się i u Laudyn, tyle że w wersji „lekarskiej”: jej Doktorka z tomiku Galeria obrazów z krainy dolara jest Polką, absolwentką medycyny na szwajcarskiej uczelni ${ }^{12}$. Samą Laudyn notabene wypadnie uznać za ilustrację zamerykanizowanej, śmiało dochodzącej swych praw kobiecości.

Schirmacher zwiedza metropolie oraz parki krajobrazowe, znajduje bratnie dusze i imponującą, „zorganizowaną energię”. Po trzech miesiącach wraca. Owdowiała Laudyn emigruje do kraju, w którym niemal nikogo nie zna, i osiedla się w nim na ponad dekadę. Rychło zyskuje uznanie jako redaktorka „Głosu Polek”, organu prasowego Związku Polek ${ }^{13}$, członkini Towarzystwa Literatów i Dziennikarzy Polskich i Polskiej Macierzy Szkolnej. Godne zauważenia jest przy tym, iż istotny argument na rzecz wyjazdu stanowiła przyjaźń dwóch kobiet, feministek, a przy tym imienniczek: Stefanii Laudyn oraz Stefanii Chmielińskiej) ${ }^{14}$ (Pienkos i Pienkos 2003: 42).

„Dojrzewanie” odbywało się na wielu płaszczyznach. Laudyn apeluje w Ameryce o równouprawnienie kobiet, a jednocześnie o samoorganizowanie się diaspory; proponuje zmiany w szkolnictwie polonijnym i wspiera kampanię polityczną drugiego męża: znacznie od niej młodszego prawnika Adama

${ }^{12}$ Tyle że wymowa Doktorki jest pesymistyczna, bo tekst powstał w fazie rozczarowania Ameryka.

13 The Polish Women's Alliance of America.

${ }^{14}$ Chmielińska była notabene pierwszą przewodniczącą Związku Kobiet w Ameryce. 
Chrzanowskiego. Schirmacher pisze oraz wygłasza odczyty, tak na światowych kongresach, jak i dla mniejszej publiczności. Jako poliglotka, z naturalnością przyjmuje na siebie funkcję pośredniczki podczas zjazdów zwolenniczek emancypacji, co doceniła między innymi redaktorka „Steru” Paulina Kuczalska-Reinschmitt w trakcie obrad Międzynarodowego Kongresu Kobiet w Berlinie w czerwcu 1904 roku:

Niezmordowaną tłumaczką przemówień angielskich [...] była dr Käthe Schirmacher, która niesłychanie bystro chwytała jądro rzeczy i niezmiernie umiejętnie oddawała nieraz z subtelną ironią właściwą treść czyjegoś przemówienia. (Kuczalska-Reinschmit 2016: 406)

Fragment ten godzien jest przypomnienia nie tylko ze względu na to, iż stanowi jedną z nielicznych w Polsce wzmianek o Schirmacher, ale przede wszystkim dlatego, że niedługo potem zarzucono niemieckiej działaczce nieuprawnione zniekształcanie wypowiedzi koleżanek zza granicy pod kątem własnych przekonań, czyli tak, by ich wystąpienia brzmiały bardziej nacjonalistycznie. Nietrudno się domyśleć, że oskarżenia te dotkliwie ją zraniły i pogłębiły jej dystans wobec ruchu kobiecego (Schirmacher 1921: 52). Przed rokiem 1905 Schirmacher jednak intensywnie udziela się w Związku Niemieckich Organizacji Kobiecych oraz żąda docenienia pracy domowej kobiet (Schirmacher 1905). Podczas kilkunastu lat spędzonych we Francji (Schirmacher 1921: 35-43) zyskuje sporą renomę i wciela poniekąd w czyn to, co zaprojektowała jako amerykańską karierę Charlotte z Die Libertad: Charlotte mianowicie otwiera praktykę adwokacką, zyskuje zaufanie nie tylko kobiet, występuje przeciw słynnemu koledze po fachu, wygrywa w imieniu klientki sprawę sądową, a w nagrodę otrzymuje... propozycję partnerstwa zawodowego oraz ślubu.

W procesie kształtowania się feminizmu oraz pisania (jego) historii nie do przecenienia są , powinowactwa z wyboru”. Odnosi się wrażenie, iż dyskurs ten, w odróżnieniu od nacjonalistycznego, wysuwa na plan pierwszy „swoich”, mniej interesując się „przeciwnikami” i „granicami”. To przyjaźnie, alianse, stowarzyszenia - kobiece rzecz jasna, chociaż pojawiają się w tym kręgu również życzliwi, otwarci mężczyźni - stanowią fundamenty przyszłego, lepszego porządku. Laudyn wzywa kobiety do zjednoczenia ponad podziałami klasowymi i politycznymi (Radzilowski 1981: 175). Schirmacher eksponuje wagę samopomocy w Die Libertad, gdzie Charlotte i Arthur zlecają literackie opracowanie planowanej przez siebie książki ubogiej Phil, nie tylko z racji jej językowych uzdolnień, ale też po to, aby dyskretnie podreperować jej budżet. Ponadto przez Die Libertad i Halb przewija się motyw opieki nad chorą, samotną towarzyszką ze studiów. 
Przynależność do wspólnoty wbudza potrzebę, ba, obowiązek utrwalenia dokonań poprzedniczek i koleżanek. Schirmacher prezentuje historię i stan ruchu emancypacyjnego od Ameryk począwszy przez Południową Afrykę i Europę po Azję i Australię (Schirmacher 1909; 1912a; 1912c); poświęca również esej Marii Deraismes (Schirmacher 1897: 361-370). Członkinie Związku Polek koncentrują się na rodaczkach, ale „Głos Polek” zamieszczał także artykuły o sufrażystkach i sytuacji kobiet w różnych państwach (Galush 1990) ${ }^{15}$.

Ceną za zaangażowanie są zmęczenie, osamotnienie, problemy ze zdrowiem. Wymowne są w tym kontekście aluzje do godzin żmudnej pracy, poczucia niezrozumienia, spacerów w pojedynkę. Schirmacher przypłaca pracę w Anglii realną chorobą, zapada bowiem na gruźlicę; później stale jest w drodze, w żywiole polemik i dyskusji (Schirmacher 1921: 20). Laudyn naraża się na ataki z rozmaitych stron. Na pewien czas musi nawet odejść z redakcji „Głosu Polek”, który ostatecznie opuszcza jako czterdziestokilkulatka z przyczyn zdrowotnych. Zna cenę sukcesu: w jednej z dedykacji mówi o „bojowaniu ciężkim”, w którym ulgę niósł jej mąż (Laudyn-Chrzanowska 1929: 2), a w kilku frazach zredagowanego przez nią listu otwartego do Marii Curie-Skłodowskiej doszukiwać się można zbieżności między doświadczeniami adresatki i doświadczeniami autorki:

[...] wbrew wszystkiemu szłaś... Łamałaś przeszkody i opór życia. Opuściłaś kraj rodzinny i w tęsknocie żrącej weszłaś samotna [...] na wielkie groźne drogi świata. (Laudyn-Chrzanowska 1921: 5)

Temat walki, wyrzeczeń oraz klęski w imię ideałów wchodzi do tekstów literackich. Anne-Marie z Die Libertad, głoduje i marznie, obmyślając obraz przeznaczony na być może przełomową dla niej wystawę. Pomoc przychodzi za późno. Przejmujący jest obraz odchodzenia artystki, która nie godzi się na śmierć zanim zdążyła rzeczywiście przeżyć życie, doświadczyć miłości i akceptacji (Schirmacher 1891: 79-81). Również Laudyn portretuje niespełnione kobiety: czynne zawodowo, acz bez większego powodzenia finansowego, wykorzystywane idealistki, nieprzystosowane do reguł kapitalistycznego Nowego Świata (Doktorka), oraz nieszczęśliwe urzędniczki, które stoją przed wyborem: kiepsko płatne zajęcie albo ubogie macierzyństwo (Zbuntowana).

Powyższe egzemplifikacje toposu ofiary nie oznaczają, iż poparcie dla feminizmu oznaczało zgodę na przyjęcie roli pustelnicy albo męczennicy. Co prawda Schirmacher w referacie wygłoszonym w Chicago w 1893 roku (Schirmacher 1897: 285-291) przyznawała, że nikłe są perspektywy małżeństwa dla niezależ-

${ }^{15}$ Schirmacher (1909: 122) także wyraża podziw dla Curie-Skłodowskiej, acz zalicza ją do Rosjanek. 
nych, nowoczesnych kobiet, a jeden z komentatorów powieści Halb konstatował, iż jej model kobiecości implikuje wykreślenie mężczyzny z „księgi życia” jako przeszkody w procesie indywidualnej samorealizacji i naprawy świata; że pisarka wybiera „celibat” w imię ideałów (Rauber 1898: 4), jednak ocena to chyba zbyt pochopna. W Die Libertad Charlotte i Arthura połączą przecież, poza uczuciem i erotyką, pasja zawodowa i społecznikowska. Ich ślub dowieść ma, że ideały nie wykluczają prywatnego szczęścia; do „rodziny” zaproszone zostają zresztą przyjaciółki. Symptomatyczna wszelako jest scena, w której Phil uzmysławia sobie, iż stoi na rozdrożu, niepewna jutra, bez wsparcia niezbędnego na co dzień, zupełnie sama w sferze domowej. Również w opowiadaniach i publicystyce Laudyn małżeństwu i macierzyństwu przypada ważna rola: rodzina jest dla pisarki niezbywalnym elementem udanej egzystencji. Tę wagę bliskości, przy pewnej odmienności dróg obu autorek, odzwierciedlają ich biografie: towarzyszkami życia Schirmacher były kobiety (w Paryżu mieszkała z przyjaciółką, późniejszy związek z Klarą Schleker powszechnie uchodził za lesbijski), Laudyn zaś dwukrotnie poślubiała mężczyzn, demonstrując także odwagę wobec konwenansów i plotek na temat różnicy wieku między nią a jej drugim mężem.

\section{Przesilenia i zwroty}

Z jakich powodów Schirmacher i Laudyn uznały prymat narodu wobec postulatów ruchu kobiecego i potrzeb upodrzędnianej w systemie patriarchalnym wspólnoty kobiecej? Co przyspieszyło owo „przesilenie”? Doniosłą rolę w procesie nowej hierarchizacji priorytetów odegrało z jednej strony doświadczenie emigracji i intensywne funkcjonowanie $\mathrm{w}$ środowisku międzynarodowym, z drugiej — wrażliwość społeczna. Obie autorki uświadomiły sobie, iż ruch kobiecy nie jest dostatecznie silny, żeby zreformować świat; że równouprawnienie kobiet i ich praca zarobkowa nie rozwiązują problemu prostytucji, wyzysku ekonomicznego ani utrudnionego dostępu pewnych grup do wykształcenia oraz wielu profesji. Zresztą zdały sobie z tego sprawę dość wcześnie, wystarczy przywołać kontrastujące ze sobą szkice Schirmacher (1900) Jak Paryż się śmieje i Jak Paryż ptacze. Ten drugi obnaża dramatyczne, ciemne strony miasta: bezradność niezdolnych do pracy, sprzedawanie się z głodu, przestępczość. Co więcej, okazuje się, że wybiórcza realizacja postulatów równouprawnienia grozi ich wyrodzeniem się we własną karykaturę:

[...] w fabrykach i zakładach [...] znoiły się i gasły w trudzie [...] siły kobiece, klekotaty $[\ldots]$ pod $[\ldots]$ palcami kobiet [...] klawisze maszynek rozmaitych [...]. Wielkie prawa pracy i zarobku zostały już [...] zdobyte, ale jakże haniebnie okrojone i wyzyskane (Laudyn 1920: 167-168). 
Dostrzeżono ponadto, iż część kobiet nie potrafiła, względnie nie chciała się wyrzec starych przyzwyczajeń oraz przywilejów i podjąć nowych zobowiązań. Nie były gotowe - w imię niepewnych jeszcze i wymagających dużych nakładów czasu i energii zysków - zaryzykować utraty akceptacji rodziny, odrzucić bezpiecznego układu z mężczyzną jako żywicielem żony i dzieci, ani obojętnie podchodzić do krzywdzących pogłosek jako możliwej społecznej reakcji na swój bunt obyczajowy. O takich właśnie dylematach i przeszkodach traktuje powieść Halb. Tytuł odsyła do opłakanej w skutkach połowiczności w realizacji celów. Główna bohaterka, studentka o imieniu Ethel, nie miała oto dość silnej woli, aby wejść do grona tych, którzy pomimo bycia w mniejszości, znajdują pokrewne dusze i wspólnie przecierają szlaki nowego ładu. Nie zgodziła się też ulec całkowicie regułom tych, którzy kultywowali mieszczański model egzystencji; stąd sama zalicza siebie do „typów przejściowych, życiowych kalek” (Schirmacher 1893: 252).

W tle tych głębokich rozczarowań pozostawały skomplikowane zjawiska polityczne i gospodarcze. Styczność z różnicami etnicznymi i kulturowymi oraz nierównościami socjalno-ekonomicznymi pogłębiała poczucie krzywdy i tendencje nacjonalistyczne. Schirmacher odnotowywała ex post.

Od 1900 widziałam co roku więcej [...]. Zobaczyłam rażącą prawdę okropnego upadku, w którym wschodziło smocze nasienie nienawiści do nas [tj. Niemców - M.B.].

[...] postanowiono przepędzić mnie z krajowego i międzynarodowego ruchu kobiecego. Słowo „niemiecki” było dla niego już tylko określeniem geograficznym [...] (Schirmacher 1921: 37, 50).

Feministki przełomu wieków odkryły (i nie ma podstaw do kwitowania ich spóźnionych rozpoznań ironią, bo przecież we wczesnych fazach działania na rzecz jakiejkolwiek idei dominuje optymizm), że kapitalizm nie chce wpisać się w wizję sprawiedliwości społecznej, że demokracja podlega „władzy pieniądza” (Schirmacher 1921: 40-42), a potęga silnych opiera się na wyzysku słabszych. Cała Galeria obrazów z krainy dolara poświęcona jest zderzeniu wyidealizowanego snu o Ameryce z głodną rzeczywistością przybyszy ${ }^{16}$. Te same zjawiska budzą gniew Schirmacher, która z zacięciem politycznym dokumentuje „szkody” ponoszone przez niemiecką diasporę w Paryżu (1915), a od wybuchu wojny coraz głośniej bije na alarm wobec rzekomego sprzysiężenia świata przeciw Niemcom.

Nie bez znaczenia dla rozpatrywanych przewartościowań był wreszcie wiek bohaterek niniejszych rozważań: Schirmacher kończy czterdzieści lat, gdy dokonuje się $\mathrm{w}$ jej poglądach owa diametralna zmiana; analogicznie rzecz ma się

${ }^{16}$ Szkice z tego cyklu ukazywały się wcześniej w prasie polonijnej, powstały zatem przed rokiem 1920. 
z Laudyn. Ich oczekiwania i wiedza zasadniczo odbiegają od młodzieńczej wiary w równouprawnienie płci jako lekarstwo na napięcia socjalne i międzyetniczne. Ta mianowicie ustępuje miejsca przekonaniu, iż o przyszłości świata zadecydują narody i klasy, a ruch kobiecy nie jest w stanie stawić czoła potężnym mechanizmom ekonomicznym i politycznym, tym bardziej, że sam wielokrotnie padał ofiarą wewnętrznych tarć i animozji.

\section{Życie i pisanie (dla) narodu}

Autorki narracji o narodzie, zastanawiając się nad przyczynami „przesilenia”, przypisują różną wagę poszczególnym osobom i wydarzeniom; indywidualne było również tempo przemian. Laudyn od początku, jak gros ówczesnych polskich feministek, skupiała się na rodaczkach, chciała je edukować i animować jako podwójnie ubezwłasnowolnione. W szkole manifestowała przywiązanie do polskości (Majewski 2001: 492), w Listach Polki z 1908 roku artykułowała wiarę w to, że kobieca solidarność przyczyni się do polepszenia relacji z Rosją (Bednarczuk 2012: 269-275). W jej amerykańskim okresie także widać splot feminizmu i nacjonalizmu. Schirmacher natomiast, choć zakorzeniona w kulturze niemieckiej, żywiła wobec niej ambiwalentne uczucia. Ani nie dopuszczono jej w ojczyźnie do studiów, ani nie uznano jej zagranicznych dyplomów uniwersyteckich (Schirmacher 1891: 29). Jako kobieta i literatka znalazła we Francji znakomite możliwości rozwoju, podczas gdy o „wyrobieniu sobie nazwiska w Niemczech” musiała zapomnieć (Schirmacher 1891: 56-58; 65; 1921: 17).

Już w Die Libertad pojawia się wszelako wątek ograniczeń wywołanych przez przynależność narodową — ważnego elementu dojrzewania do nacjonalizmu. Otóż we Francji kariera nauczycielska stałaby przed Phil — jak wspomniałam, alter ego autorki opowiadania — otworem, gdyby niemiecka absolwentka Sorbony zdecydowała się na naturalizację (Schirmacher 1891: 65). Inne sygnały etnicznej (nad)wrażliwości pisarki znajdziemy w tomie szkiców Paris! (1900), w którym spod pokładów sympatii dla Francji wyłaniają się ostrzeżenia przed jej upadkiem. Nadzwyczaj ostro mówi zaś Schirmacher we wspomnieniach o swoim ideowym dorastaniu, sięgając po wyrażenia kojarzone z demaskowaniem fałszu: „przejrzeć na oczy”, „dostrzec prawdę”. Laudyn staje wobec podobnego dylematu. Chociaż w Ameryce może niemal bez skrępowania wypowiadać się na niwie publicznej, nagle postanawia „zedrzeć pozory fałszywe z rzeczy błyszczących [...], strącić maski obłudne z stosunków i prawd opłakanych", nie tylko zresztą amerykańskich, bo i polsko-polskich (Laudyn 1920: 5).

W pismach obu autorek zauważalna jest zależność między natężeniem poczucia bycia gorzej traktowanym a dłuższym pobytem za granicą. Istotę (biografii) 
narodu dookreśla się bowiem poprzez odniesienie do innych nacji i odgraniczenie się od nich jako obcych, odmiennych (Manzo 1996: 37-70; por. Bokszański 2001: 100-102). W odróżnieniu od opowieści obydwu działaczek o dorastaniu do feminizmu, w tekstach poświęconych kwestiom emigracyjnym podkreślane są osobiste doświadczenia dyskryminacji. Schirmacher odczuwa w Paryżu obcość mimo doskonałej znajomości języka i kultury francuskiej (Schirmacher 1921: 16). Nie chce się wypierać korzeni, toteż odrzuca pomysł przyjęcia obywatelstwa. Ciekawa jest przy tym dynamika interakcji międzykulturowych. Zanim napięcie przerodzi się w jawną wrogość, inspiruje. Odnotować także należy, iż niechęć do innych wspólnot pojawia się na kilka lat przed otwartym starciem zbrojnym. Schirmacher przestaje bezwarunkowo akceptować Paryż po pierwszych pięciu latach, nie inaczej niż Laudyn rzeczywistość Chicago. Ujawniają się grube pęknięcia na harmonijnym dotąd obrazie:

W walce o przetrwanie na [...] międzynarodowej arenie zwycięża ten naród, którego wodzowie widzą najdalej, którego masy są najbardziej praktycznie wykwalifikowane, który cechuje najwyższy stopień społecznej spójności [...] (Schirmacher 1900: 14)

Początkowo obserwacje są ogólnej natury. Stopniowo zastąpią je formułowane wprost zarzuty, adresowane zarówno do własnej, jak i do „drugiej” strony. Pierwsza biernie przygląda się wyjazdom robotników, rzemieślników i wykształconych mężczyzn i kobiet, którzy — mimo niskich płac i braku ochrony prawnej - przyczyniają się do rozwoju przemysłu, handlu i usług drugiego państwa. Nie przygotowuje ich na niebezpieczeństwa typu przesadna zależność ekonomiczna lub zejście na złą drogę (Schirmacher 1915). Druga traktuje imigrantów, prostolinijnych, nieświadomych wielu pułapek, słabo zaznajomionych z miejscowym językiem i zwyczajami, z góry; bez skrupułów ich wyzyskuje, oferując nader niewiele w zamian za przykładną pracowitość.

Niejeden zasiedziały mieszkaniec Stanów Zjednoczonych okazuje się „katem” (Laudyn 1920: 178-179). Co gorsza, nowa „ojczyzna” „podkrada” niezorganizowanym, słabym diasporom członków poprzez politykę naturalizacji drugiego pokolenia. Schirmacher (1915) uwiera historyczne francuskie droit du sol; z racji kultywowania na obczyźnie kultury niemieckiej o wiele bliższe byłoby jej Ius sanguinis. Zdaniem Laudyn, Amerykanie postępują podobnie, dążąc do asymilacji słabszych kulturowo i gospodarczo przybyszy, czyli, z perspektywy mniejszości narodowych, do zawłaszczenia ich dzieci:

Dziecko uczy się kochać, czcić i wielbić tylko tę Amerykę wspaniałą, która mu daje [...] bogatą szkołę bezpłatną, miłą, dobrą nauczycielkę, książki, zabawy i śniadania nieraz. [...] I byłoby to dobre też i pożądane, gdyby nie zabijało w nim odrębnej, swoistej duszy polskiej, czyniąc ją wytworem pospolitym, przeciętnym kultury obcej. 
[...] Niebo, ziemia, ludzie, [...] otoczenie, kultura i natura — wszystko zagłusza i rujnuje tę polskość w nas całą, którą utrzymać [...] za wszelką cenę chcemy i dzieciom ją przekazać. (Laudyn 1914: 32, 16)

Redaktorkę „Głosu Polek” razi to tym bardziej, że w polskiej pamięci żywe jest wspomnienie Wrześni, symbolu narodowej martyrologii. W takich konstelacjach etniczno-politycznych znika płeć i ginie ze szczętem kobieca solidarność.

Schirmacher i Laudyn coraz żarliwiej nawołują do odnowy moralnej ludzkości, najpierw jednak do poprawy położenia „swoich” (Schirmacher 1910; Laudyn-Chrzanowska 1933). Podczas gdy pierwsza niebezpieczeństwo upatruje we Francuzach $^{17}$, Anglikach, Żydach oraz Słowianach i tłumaczy swoje nieudane próby dramatyczne w Paryżu niemieckim pochodzeniem, druga krytycznie podchodzi co prawda do Amerykanów, za głównego przeciwnika Polaków uważa jednak ludność żydowską (Laudyn 1917). Z czasem narastać będzie u obydwu niechęć do demokracji i strach przed rewolucją, bo zdewastowana Rosja wywoła na równi obawy i współczucie jako domena „pierwotnej siły” (Schirmacher 1921: 57-58), a zarazem przestroga (Schirmacher 1932: 26-28; Laudyn-Chrzanowska 1933).

Jak (re)konstruowana jest teraz geneaologia? Odwrotnie niż w dyskursie feministycznym, gdzie — chociaż akcentowano zasługi ojców — dominowało siostrzaństwo i „powinowactwa z wyboru”, ponad granicami, tutaj rysowana jest linia wyraziście męska oraz wsobna kulturowo. Wymiaru narodowych alegorii nabierają u Laudyn figury powstańców styczniowych (Umęczone Orty 63 roku) i uczniów bitych za lojalność wobec polszczyzny (Września), w większości mężczyzn lub chłopców. Schirmacher wymienia z kolei wśród bohaterów swej wspólnoty Augusta von Gneisenau, Gebhardta von Blüchera, Ottona von Bismarcka i Helmuta von Moltke (Schirmacher 1932: 36). Jedna znajduje pokrewną duszę w Wilhelmie von Massow ${ }^{18}$, druga — w Jędrzeju Giertychu.

W opowieści o narodzie ważka rola przypada jego personifikacjom. Przytoczę dwa przykłady, sądzę że dosyć reprezentatywne. Pierwszy pochodzi z noweli Laudyn Zatracony. Ciało głodnego, schorowanego imigranta, któremu nie powiodło się za oceanem, a który rozpaczliwie tęsknił do ziemi ojców i zmarł w samotności, trafia po śmierci do prosektorium, pod nóż anatomów, stając się metaforą rozkrojonej na mapie, bezimiennej jak on — bo nieistniejącej politycznie - Polski. Pisarka przeprowadza nawet paralelę między nim a Chrystusem: „zabite krzywdą i niedolą dziecko rozpięte na krzyżu męki swej — Ojczyzny”

${ }^{17}$ Nawet możliwość studiów we Francji interpretowana jest ex post w kategoriach historycznych porachunków: była to „rekompensata” za krzywdy wyrządzone przez Francuzów Gdańszczanom podczas wojen napoleońskich, dokładniej za „40 milionów wymuszonych i skradzionych talarów”, w tym majątek jej pradziadka. „Część z tego sobie odebrałam” (Schirmacher 1921: 17).

${ }^{18}$ Von Massow jest autorem antypolskiej książki Die Polen-not im Deutschen Osten (1903). 
(Laudyn 1920: 201). Drugi przykład zaczerpnęłam z pośmiertnego wydania prac Schirmacher Um Deutschland (1932: 20-23). W centrum jednego z jej obrazków obyczajowych stoi żona fabrykanta, która wskutek wojny i braku wsparcia straciła już prawie wszystko: mąż zginął, ona wyprzedała, co mogła, wynajęła obcym wszystkie pokoje w mieszkaniu, a mimo to głodowała i marzła, snując myśli o samobójstwie.

Uderza, oczywiście, odmienność kontekstów: bohater Laudyn nie może wrócić do swoich, a gdyby nawet wrócił, nie byłby w pełni wolny, podczas gdy postać z fabuły Schirmacher cierpi w suwerennym państwie, zaniedbana, jak wielu jej rodaków, przez władze. W pierwszym wypadku problemy ekonomii nakładają się na dyskryminację na tle narodowościowym, w drugim chodzi o wojnę i kryzys gospodarczy, dotykający wszak w jakimś momencie wszystkich grup społecznych. Na tym tle jaskrawo uwidacznia się specyficzna, selektywna świadomość omawianych publicystek. Laudyn, nagłaśniając krzywdy Polaków, ignoruje fakt, iż społeczeństwo amerykańskie nie było ani nie jest homogeniczne, że składa się z diaspor, wśród których są i takie, które znajdują się w sytuacji podobnej lub gorszej niż Polonia. Schirmacher, zbulwersowana odgórnym przyznawaniem francuskiego obywatelstwa dzieciom urodzonym w granicach tego państwa niezależnie od ich pochodzenia, od 1904 głośno afirmuje tzw. hakatyzm i niemieckie osadnictwo w Prusach (Schirmacher 1912b: 6; 1921: 47-49; 1922; 1925). Agituje też na rzecz Niemieckiego Związku Marchii Wschodniej, apelując, aby nie oddawać ani piędzi ziemi „barbarzyńskim” w jej odczuciu Słowianom (tu: Polakom).

I wojna światowa postawiła ruch kobiecy przed nierozstrzygalnymi wyborami. Na Kongresie w Hadze, w roku 1915, Zofia Daszyńska-Golińska mówi o „tragicznej” codziennej walce Polek pozbawionych własnego państwa, lecz nie nasuwają się jej na myśl analogie z kobietami żydowskimi, ani Ukrainkami czy Czeszkami pozbawionymi przedstawicielek na tymże zjeździe. Helene Lange, demokratka i feministka niemiecka, po traktacie wersalskim optuje za niewysyłaniem delegacji na kolejny kongres międzynarodowy:

Dla wielu niemieckich kobiet uzasadnienie tej decyzji jest zupełnie zbędne. [...] Nędza i poniżenie naszej ojczyzny wypełniają ich dusze tak dalece, że dyskutowanie [...] o jakichś kwestiach kobiecych [...] wydawać się im musi bardzo nieistotne. (Lange 1920: 239)

Lata 1914-1919 były zatem potężnym ciosem dla ruchu kobiecego. Schirmacher jednak już od końca pierwszej dekady XX wieku opowiada się po stronie narodu. Kiedy delegatki z różnych stron świata oczekują od niej deklaracji dystansu wobec imperialistycznej polityki Niemiec, demonstracyjnie odrzuca 
te sugestie, przekonana o zdradzie. Lecz gotowa jest ponieść konieczne ofiary: żegna się z Paryżem i kongresami kobiet. Woli lojalność wobec własnego narodu od „zgody z Polakami”, jaką do 1913 roku preferują feministki (Schirmacher 1921: 49). Pocieszenie znajduje i tym razem w przyjaciółkach, tych, w których „duszach płonął narodowy ogień”, zwłaszcza Klarze Schleker, do której się przeprowadza.

Od tej pory zauważalna jest $\mathrm{w}$ jej pismach jeszcze jedna zmiana paradygmatu: ruch feministyczny wiązał się z nowoczesnością, postępem, mieszczaństwem, w życiorysie Schirmacher w szczególny sposób łączy się z nim Paryż (w biografii Laudyn - Chicago); ruch nacjonalistyczny programowo powraca na wieś, do ziemi, wsi. „Już nie mogłam patrzeć na wielkie miasta” — oznajmia dojrzała Schirmacher (Schirmacher 1921: 62). Drzewa, lasy, pola podnoszone są do godności symboli niemieckości, stąd nakaz ich obrony do ostatniej kropli krwi (Schirmacher 1932: 13-15, 34-36). W publikacjach Laudyn trudniej wskazać owo przejście, gdyż z racji zaborów postulaty emancypacji kobiet oraz narodu nieustannie się przeplatały, jawnie bądź podskórnie. Ale symboliczne są już przenosiny w 1922 roku z Chicago do Zakopanego, górskiego miasteczka na prowincji (mimo że coraz bardziej turystycznego), oraz wypowiedzi nawiązujące do popularnego wśród nacjonalistów mitu Anteusza nabierającego sił w kontakcie z ziemią ${ }^{19}$ :

[...] tam [...] [w Polsce - M.B.] pod stopami jest własna pradawna ziemia, mówiąca $[\ldots]$ wciąż głosami żywych i umarłych, $[\ldots]$ tam powietrze, natura, chwila obecna i przeszła - wszystko pełne polskości, jej mocy, ciepła, czaru, umiłowania. (Laudyn 1914: 16)

\section{Kobiety (dla) wspólnoty}

Wizja kobiecości podporządkowanej służbie wspólnoty narodowej to powrót do punktu wyjścia, sprzed podniesienia sztandaru emancypacji. W pracy Die moderne Jugend (1910) dokonała Schirmacher diagnozy współczesnego świata i wciąż jeszcze problematyzowała sprawę szkodliwości niektórych tradycyjnych wzorców. Dystansu wobec konserwatywnego modelu ładu społecznego brak natomiast w opublikowanej podczas wojny książeczce Völkische Frauenpflichten (1917), w której pisarka zajęła się niemal wszystkimi aspektami egzystencji dziewcząt i kobiet, posuwając swe wymagania do niedorzeczności. Co proponowała? Dobór mebli i sprzętów domowych pasujących do niemieckiego ducha, funkcjo-

19 Por. powieść Romana Dmowskiego Dziedzictwo, opublikowaną po raz pierwszy w roku 1930 (Wybranowski 1997: 42), oraz artykuły z „Myśli Narodowej” (np. Frycz 1937). 
nalnych, wytworzonych przez rodzime firmy; dbałość o słoneczne mieszkania; „niemiecki” ubiór, jak najdalszy od zachodnich mód. Laudyn w tym czasie (1917: 85; 300-302) wybiera inną taktykę wywyższania własnej wspólnoty; ukazuje Polaków jako grupę ekskluzywną z powodu wyjątkowego cierpienia, także ze strony Żydów, i swojej misji. Dlatego na czele pochodu „narodów męczeńskich [...] zgwałconych, zabitych niewolą”, stawia „żarząc[ą] się płomiennie” „trójcę krwawą", czyli Polskę, Belgię i Serbię.

Prawdziwym wyznacznikiem lojalności nie była jednak walka piórem ani inną bronią, ale macierzyństwo, rozumiane dosłownie bądź przenośnie. Niemki winny uzyskać porządne zawodowe wykształcenie i rozsądnie się odżywiać, aby dać życie zdrowym dzieciom. Schirmacher napiętnuje warstwę urzędniczą i elity za to, iż redukowały liczbę potomstwa „z wygody”. Podobnie czynią naonczas bliscy Laudyn młodzi, polscy narodowcy (Giertych 1930). Z wielu stron dobiegają zresztą nawoływania do demograficznego wyścigu, ignorujące zupełnie kontekst gospodarczy i prawo każdej pary do podejmowania decyzji w tym zakresie.

Motywacja poszczególnych nacjonalistek nosi naturalnie indywidualne piętno. Ton Laudyn jest raczej katastroficzny niż rozkazujący; w jej wypadku to elementy religijne, zazębiające się z antykapitalistycznymi i antybolszewickimi, przeważyły szalę. Schirmacher wydaje polecenia, jest nieustępliwa; od młodości towarzyszy jej myśl Nietzschego, pragnienie zwycięstwa, przeforsowania swoich argumentów (Schirmacher 1917: 39-59). Przy tym upiera się przy idei politycznego równouprawnienia płci, proponuje kobietom dbanie o kondycję fizyczną, stwarza nawet plan żeńskiej służby wojskowej (Schirmacher 1921: 74). Od 1917 jeździ na front z odczytami, później włącza się w prace Reichstagu. Nie rezygnuje z polityki, nawet gdy traci mandat wskutek przyznania Polsce terenów, które miała reprezentować. Ta strata wywołała u niej traumę i pogłębiła jej antypolskie poglądy. Podobnie wrogie wobec Żydów wypowiedzi Laudyn można wyjaśnić przykrymi osobistymi przeżyciami. Publicystka nie mogła się pogodzić z antypolską kampanią prasy żydowskiej w USA pod koniec wojny, a miejsce Nietzschego zajęło u niej chrześcijaństwo dryfujące coraz bardziej ku polskiemu nacjonalizmowi.

Co je łączyło? Dobrowolne podporządkowanie „wyższej”, zbiorowej instancji. Stąd wynikało przeświadczenie, iż obowiązkiem kobiet w obliczu zagrożenia wspólnoty jest reprodukcja wzorców kultury narodowej, czyli dbałość o ciągłość międzygeneracyjnego przekazu, opowiadanie dzieciom i wnukom o heroicznej ofierze przodków, mężów i braci. Kobieta winna wpajać potomkom zamiłowanie do historii i języka ojczystego oraz stać na straży etnicznych oraz biologicznych granic poprzez zapobieganie związkom z reprezentantami obcych, „mieszaniu ras” (Schirmacher 1917: 34-53). U fundamentów tej narracji leży 
pamięć o wspólnych doznaniach, razem przeżytych wydarzeniach i przywiązanie do konkretnego miejsca.

Elementem wspólnym prezentowanym autorkom była też aktywność na rzecz podniesienia poziomu moralnego ludzkości, co nie oznacza bynajmniej pełnej akceptacji dogmatów i nauk głoszonych przez skłócone ze sobą kościoły chrześcijańskie. Schirmacher czyniła wysiłki w kierunku naprawy obyczajów przez cały niemal okres swej aktywności, zamieszczała między innymi szkice na łamach periodyku „Ethische Kultur”, organu prasowego sekularnego ruchu znanego jako Ethische Bewegung oraz Ethical Humanism, a zorientowanego na wzmocnienie w społeczeństwie wzajemnego szacunku, uczciwości i solidarności obywateli, jednak nie w oparciu o religijne nakazy moralne, lecz o świeckie zasady etyczne (por. Wyss 1893). Laudyn od lat spędzonych w Rosji i Galicji po przenosiny do Zakopanego kładła nacisk na moralny postęp, gotowa jednak wejść w spór z duchownymi katolickimi, jeśli uznała ich postępowanie za niesłuszne lub godzące w interesy Polonii (zob. Laudyn 1914: 53; Majewski 2004: 24-25).

Lata powojenne w jakimś sensie przyniosły obydwu działaczkom spełnienie. Swoją autobiografię kończy Schirmacher następującymi zdaniami:

W objawieniu ojczyzny najwyraźniej przemawia do mnie Bóg. Jestem człowiekiem, ale niemieckim. To jest tym, co elementarne, podstawowe.

$[\ldots]$

Ojczyzną, Niemcami — tym powinniście być! (Schirmacher 1921: 95)

Pod apelem o stopienie się w jedno ze wspólnotą narodową, o zatracenie się w niej podpisać mogłaby się również Stefania Laudyn, która w Marii Curie-Skłodowskiej widzi kontynuację walki „żołnierzy polskich na posterunkach [...] matek i żon, co [...] posyłały niezłomnie mężów na szubienice”, i wierzy w „człowieka zbiorowego" (Laudyn 1921: 5) oraz to, iż „Serca młodzieży to wrota niebios” (Laudyn 1933: 103, 171). Dlatego pokłada nadzieję w pokoleniu sakralizującym naród, jak Jędrzej Giertych (Laudyn 1933: 169).

Nośny przekaz końca lat 20. i 30. w Europie nie brzmiał: „masz prawo do samorealizacji” (w domyśle: bez względu na płeć), lecz „bądź gotów zginąć za naród". Wobec tak sformułowanych priorytetów pragnienia kobiet zeszły na dalszy plan. A Käthe Schirmacher oraz Stefania Laudyn zapłaciły wysoką cenę za oddanie etnosowi i zepchnięcie ideałów ruchu kobiecego na dalszy plan: współcześnie ani feministki nie kultywują pamięci o nich, mimo niewątpliwych zasług obu aktywistek, ani stronnictwa nacjonalistyczne — tradycyjnie androcentryczne i zdominowane przez mężczyzn — nie przyjęły ich z otwartymi ramionami i nie wpisały do swoich annałów. 


\section{BIBLIOGRAFIA}

Anderson Benedict. 1983. Imagined Communities. Reflections on the Origin and Spread of Nationalism. London-New York: Verso.

Bednarczuk Monika. 2012. Kobiety w kręgu prawicy międzywojennej: idee, sylwetki, strategie pisarskie. Wrocław: A-linea.

Bhabha Homi K. 1990. Introduction: Narrating the Nation. In: Nation and Narration. Red. Homi K. Bhabha. Lodon-New York: Routledge. S. 1-7.

Bokszański Zbigniew. 2001. Stereotypy a kultura. Wrocław: Fundacja na Rzecz Nauki Polskiej - Leopoldinum.

Daszyńska-Golińska Zofia. 1915. Memorial presented on behalf of the Polish delegation. W: Bericht-Rapport-Report by Women's International League for Peace and Freedom. 1st congress: 1915. The Hague. Amsterdam: International Women's Committee of Permanent Peace. S. 230-232.

Friedman Susan Stanford. 1998. Women's Autobiographicasal Selves: Theory and Practice. W: Women, Autobiography, Theory: A Reader. Red. Sidonie Smith, Julia Watson. Madison: The University of Wisconsin Press. S. 72-82.

Frycz Karol Stefan. 1937. Na widowni. „Myśl Narodowa”, nr 15. S. 233-234.

Galush William J. 1990. Purity and Power: Chicago Polonian Feminists, 1880-1914. „Polish American Studies”, t. 47, nr 1. S. 5-24.

Gehmacher Johanna. 2000. Der andere Ort der Welt. Käthe Schirmachers Auto/Biographie der Nation. W: Geschlecht und Nationalismus in Mittel- und Osteuropa, 1848-1919. Red. Sophia Kemlein. Osnabrück: Fibre. S. 99-124.

Giertych Jędrzej. 1930. O kierunek wychowania dziewcząt. Poznań: W. Krakowiecki.

Heilbrun Carolyn G. 1988. Writing a Woman's Life. Foreword by Katha Pollitt. New York: W.W. Norton.

Hüchtker Dietlind. 2009. Cross-mapping. Lokale Verankerungen und transnationale Netzwerke in den Narrativen ostmitteleuropäischer Frauenbewegungen um 1900. W: Vergessene Vielfalt: Territorialität und Internationalisierung in Ostmitteleuropa seit der Mitte des 19. Jahrhunderts. Red. Steffi Marung, Katja Neumann. Göttingen: VandenhoeckRuprecht. S. 166-193.

Kuczalska-Reinschmit Paulina. 2016. E pur si muove... Publicystyka spoteczna z lat 1881-1918. Wybór i wstęp Agata Zawiszewska. Szczecin: Wydawnictwo Uniwersytetu Szczecińskiego. Międzynarodowe zjazdy kobiet. S. 404-418.

Kurczewska Joanna. 1999. Pierwsi nacjonaliści polscy i sprawy kobiet. „Archiwum Historii Filozofii i Myśli Społecznej”, t. 44. S. 191-201.

Lange Helene. 1920. Kampfzeiten. Aufsätze und Reden aus vier Jahrzehnten. Berlin: F.A. Herbig. T. 2. Die deutschen Frauen und der Frauenweltbund. S. 239-242. 
Laudyn Stefania. 1895. Zmarnowane życie. Dramat w 5-ciu aktach. Lwów: Gubrynowicz i Schmidt.

Laudyn Stefania. 1908. Kwestia polska i inne. Listy polityczne „Polki” drukowane w gazecie „Rus” od 1 (14) października 1904 r. po 10 (24) listopada 1907 r. Warszawa: Drukarnia L. Bilińskiego i W. Maślankiewicza.

Laudyn Stefania. 1914. Szkoty parafialne a publiczne. Z religia czy bez religii? (Odb. z „Dziennika Chicagoskiego”). Chicago: Nakładem Polskiej Rady Narodowej w Ameryce.

Laudyn Stefania. 1917. Sprawa światowa. Żydzi - Polska - ludzkość. Chicago: The Two Little Printers.

Laudyn Stefania. 1920. Galeria obrazów z krainy dolara. Zbiór nowel na tle życia polsko-amerykańskiego. Chicago: Polish American Publishing.

Laudyn Stefania. 1921. Czcigodnej Pani Marii Curie w hotdzie od Polonii w Chicago, dnia 15 czerwca 1921 r. Chicago [b. wyd.].

Laudyn Stefania. 1925. Umęczone orty 63 roku: dramat w 3 aktach. Chicago: Drukarnia „Dziennika Zjednoczenia”.

Laudyn-Chrzanowska Stefania. 1929. Wyzwólmy siebie i świat. Milwaukee: Wydawnictwo „Kuryera Polskiego”.

Laudyn-Chrzanowska Stefania. 1933. Prawo powszechności. Dtug jednostki. Zakopane: Nakładem Autorki.

Majewski Karen. 2001. Laudyn Stefania (Laudyn-Chrzanowska).W: Women Building Chicago, 1790-1990. A Biographical Dictionary. Red. Rima Lunin Schultz, Adele Hast. Bloomington-India-napolis: Indiana University Press. S. 492-494.

Manzo Kathryn A. 1996. Creating Boundaries: The Politics of Race and Nation. Boulder -London: Lynne Riener Publishing.

Niethammer Ortrun. 1996. Holocaust und Gedächtnis: Autobiographien von nationalsozialistischen Autorinnen. W: Frauen und Nationalsozialismus. Historische und kulturgeschichtliche Positionen. Red. Ortrun Niethammer. Osnabrück: Universitätsverlag Rasch. S. 100-112.

Pienkos Angela T., Pienkos Donald E. 2003. "In the Ideals of Women is the Strenght of a Nation": The Polish Women's Alliance of America. Boulder-New York: Columbia University Press.

Radzilowski Thaddeus. 1981. „Let Us Join Hands”: The Polish Women's Alliance. W: Immigrant Women. Red. Maxine Schwartz Seller. Philadephia: Temple University Press. S. 174-180.

Rauber August. 1898. Käthchen Schirmacher's „Halb” und Eduard von Hartmann's „Ganz” vom biologischen Standpunkte aus beurtheilt. Zwei akademische Reden [...]. Leipzig: A. Georgi.

Rowbotham Sheila. 1973. Woman's Consciousness, Man's World. London: Penguin.

Schirmacher Käthe. 1891. Die Libertad. Novelle. Zürich: Verlags-Magazin. 
Schirmacher Käthe. 1893. Halb. Leipzig: W. Friedrich.

Schirmacher Käthe. 1897. Aus aller Herren Länder: gesammelte Studien und Aufsätze. Paris-Leipzig: Welter.

Schirmacher Käthe. 1900. Paris! Berlin: A. Schall.

Schirmacher Käthe. 1905. Die Frauenarbeit im Hause. Ihre Ökonomische, rechtliche und sociale Wertung. Leipzig: F. Dietrich.

Schirmacher Käthe. 1909. Die moderne Frauenbewegung. Ein geschichtlicher Überblick. Leipzig: B. Teubner.

Schirmacher Käthe. 1910. Moderne Jugend. Ein Wegweiser für den Daseinskampf. München: E. Reinhardt.

Schirmacher Käthe. 1912a. Die Suffragettes. Weimar: A. Duncker.

Schirmacher Käthe. 1912b. Die Verteidigung der Ostmark. Vortrag gehalten am 4. Ostdeutschen Frauentage in Lissa. Posen: O. Eulitz.

Schirmacher Käthe (1912c). Sufrażetki. Za zezwoleniem Autorki przeł. Melania Bersonowa. Lwów: Wydawnictwo „Kultura i Sztuka”.

Schirmacher Käthe. 1915. Die nationalen Schäden der deutschen Einwanderung in Paris. Berlin [b. wyd.].

Schirmacher Käthe. 1917. Völkische Frauenpflichten. Berlin: Augustin-C. Hamel.

Schirmacher Käthe. 1921. Flammen. Erinnerungen aus meinem Leben. Leipzig: Dürr-Weber.

Schirmacher Käthe. 1922. Die Geknechteten (Die reichsdeutsche Irredenta). Berlin: Brunnen-Verlag K. Winckler.

Schirmacher Käthe. 1925. Grenzmarkgeist. Langensalza: J. Beltz.

Schirmacher Käthe. 1932. Um Deutschland. (Nachgelassene Schriften). Berlin: Verlag Memelland.

Stegman Natali. 2000. Die Töchter der geschlagenen Helden: „Frauenfrage”, Feminismus und Frauenbewegung in Polen 1863-1918. Wiesbaden: Harrasowitz.

Tönnies Ferdinand. 1922. Gemeinschaft und Gesellschaft: Grundbegriffe der reinen Soziologie. Wyd. 3. Berlin: K. Curtius.

Wong Hertha D. Sweet. 1998. First-Person Plural: Subjectivity and Community in Native American Women's Autobiography. W: Women, Autobiography, Theory: A Reader. Red. Sidonie Smith, Julia Watson. Madison: The University of Wisconsin Press. S. 168-178.

Walzer Anke. 1991. Käthe Schirmacher. Eine deutsche Frauenrechtlerin auf dem Wege vom Liberalismus zum konservativen Nationalismus. Pfaffenweiler: Centaurus.

Wybranowski Kazimierz [właśc. Roman Dmowski]. 1997. Dziedzictwo. Wstęp Michał Kałuski. Wrocław: Nortom.

Wyss Friedrich. 1893. Die ethische Bewegung in Amerika und Deutschland. Leipzig [b. wyd.]. 


\title{
THE SELF, COMMUNITY, AND WRITING: KÄTHE SCHIRMACHER AND STEFANIA LAUDYN-CHRZANOWSKA BETWEEN FEMINISM AND NATIONALISM
}

\author{
(summary)
}

Two controversial women, a German and a Pole, are presented in this comparative study. Käthe Schirmacher and Stefania Laudyn-Chrzanowska were radical women's rights advocates who became passionate nationalists. The article is an attempt at interpreting their lives and writings as a kind of self-narration and at the same time a narration of community (identity). As Carolyn Heilbrun puts it, a woman can write her life by telling it in an autobiography, she can write it as a fictional narrative or write it "in advance by living it". Therefore, the paper focuses on both texts and (real) lives.

Moreover, individual identity continuously intersects with group identity in the biographies and narrations displayed here. For Schirmacher and Laudyn narrating the self often means narrating community: either narrating the imagined women's community or narrating the nation. Hence both authors challenge the model of an autonomous individual narrating a single life.

A further point of departure is the relationship between identity and interaction with other languages or national groups. It is not entirely coincidental that Schirmacher and Laudyn developed strongly nationalistic and anti-Semitic attitudes after having lived abroad for a long period of time. The first few years were marked by a deep belief in supra-national women's organizations and women's solidarity. Then a kind of "political solstice" took place (Schirmacher). Obviously, the radical change of views was due to a number of factors but the everyday confrontation with "the other" intensified the awareness of cultural boundaries and resulted in the sacralization of their own respective nations.

The paper offers thus a double portrait of both activists as feminists and nationalists, and also, more or less deliberately, chronists of two different, though intertwined, 'imagined communities'.

\section{KEYWORDS}

subjectivity and community; narration; early feminism; German and Polish nationalism in $20^{\text {th }}$ century; political solstice; Stefania Laudyn-Chrzanowska; Käthe Schirmacher 

Prace Polonistyczne, seria LXXII, 2017

ISSN: 0079-4791; e-ISSN: 2450-9353

DOI: $10.26485 / \mathrm{PP} / 2017 / 72 / 10$

Lidia Ignaczak

\section{OD LES GOGUETTES DO KABARETÓW, CZYLI O ZALEŻNOŚCIACH MIĘDZY FRANCUSKĄ I POLSKĄ PIOSENKĄ KABARETOWĄ W LATACH 1881-1911}

\section{SŁOWA KLUCZOWE}

historia teatru XIX i XX wieku; Paryż XIX wieku; fin de siècle; kabaret; modernizm; literatura XIX wieku; piosenka

\section{Wprowadzenie}

Integralną częścią historii polskich kabaretów jest przeświadczenie o ich zależności od estetyki paryskich nadscenek. W artykule Tęsknota za Chat Noir i Mirliton. Wokót legendy paryskich kabaretów (Ignaczak 2016: 280, 308) postulowałam potrzebę dokładniejszego zbadania tego zagadnienia ze względu na brak przekonujących argumentów, które potwierdzałyby silną organiczną więź Zielonego Balonika, Figlików, Momusa, Sfinksa, Mirażu czy Qui Pro Quo z kabaretami Montmartre'u.

Wydaje się konieczne prześledzenie procesu zmian jakim podlegały środowiskowe uwarunkowania decydujące o artystycznym kształcie twórczości paryskich i polskich kabaretów, by możliwe było wskazanie miejsc wspólnych, ale też różnic.

Każde środowisko — przekonywali Deleuze i Guattari — rządzi się kodem, który znamionuje okresowa powtarzalność, każdy kod jednak jest nieustannie przekodowywany i przenoszony. Przekodowywanie i przenoszenie jest sposobem, w jaki pewne

Lidia Ignaczak — dr, Katedra Literatury i Tradycji Romantyzmu, Instytut Filologii Polskiej, Wydział Filologiczny, Uniwersytet Łódzki, ul. Pomorska 171/173, 90-236 Łódź; e-mail: lidia.ignaczak@uni.lodz.pl 
środowisko służy za podstawę innemu środowisku, albo na odwrót osadza się w innym środowisku, rozprasza się w nim bądź rozbudowuje. (Deleuze, Guattari 2015: 380)

Autorzy Tysiąca plateau proponują, by uważnie badać te czynniki, które decydują o terytorializacji środowiska, o powtarzalności rytmu danego miejsca oraz jego zmianie. W przypadku kabaretów pojawianie się i znikanie repetycyjności możliwe jest do opisania na poziomie rytualizacji przebiegu kabaretowych zdarzeń ${ }^{1}$ oraz w obszarze refreniczności form słowno-muzycznych. Można założyć, że próba przeniesienia wzorca kabaretowego z Paryża do Warszawy czy Krakowa stworzyła w nowym środowisku konieczność ponownego doboru środków słowno-muzycznych, wyeliminowania lub wyłączenia tych elementów performatyki kabaretowej, które w polskich realiach nie spełniały oczekiwanej funkcji.

W jakim więc stopniu pejzaż słowno-muzyczny pierwszych paryskich kabaretów był podobny do krajobrazu melicznego polskich kabaretów początku XX wieku? Z jakich rytmów charakterystycznych dla kabaretów Montmartre'u zrezygnowano świadomie bądź nieświadomie w krakowskich i warszawskich teatrzykach kabaretowych tamtego czasu? Jaki był mechanizm przekodowywania estetyki kabaretowej? Co zadecydowało o tym, że z biegiem czasu owa manifestowana więź polskich kabaretów z paryskim pierwowzorem rozluźniała się w praktyce scenicznej? Z jakich powodów pragnienie Tadeusza Boya-Żeleńskiego, by przeszczepić nadsekwańską tradycję piosenki do polskich kabaretów, okazało się niemożliwe do spełnienia? Czy można potwierdzić prawdziwość twierdzenia, że „Po Francji odziedziczyliśmy piosenkę” (Mościcki 2008: 20) kabaretową? Uzyskanie odpowiedzi na powyższe pytania będzie możliwe tylko wówczas, gdy w owym porównawczym zestawieniu nie ograniczymy się do literaturoznawczej komparatystyki, a włączymy do badań perspektywę socjologiczną, pozwalającą odsłonić specyfikę obiegu piosenki w tych dwu interesujących nas kręgach kulturowych. Pierwszym ważnym zadaniem jest przywrócenie pełnej wiedzy o swoistości i złożoności społecznej cyrkulacji meliki francuskiej — wiedzy wypartej z kultury polskiej przez mityczny konstrukt, który powielany przez lata zastygł w stereotypie.

Wśród nielicznych polskich artystów i publicystów zainteresowanych wielostronnym poznaniem tego zjawiska, można wyróżnić trzy frakcje: miłośników estetyki paryskich kabaretów, takich jak Boy czy Leon Schiller, zabiegających o przeszczepienie owej tradycji pieśniarstwa na polski grunt (Karwacka 1982: 133); sceptyków, takich jak Jan Lorentowicz, który podziwiał wysiłek autora Stówek, ale wątpił, by kabaretowa śpiewka zyskała kulturową trwałość i powszechną siłę oddziaływania (Lorentowicz 1924: 1-2); wreszcie przeciwników podobnych

1 Zagadnienie to opisałam szczegółowo w artykule: Tęsknota za Chat Noir i Mirliton. Wokót legendy paryskich kabaretów (Ignaczak 2016: 279-308). 
Miriamowi, który miał świadomość, że w drodze przez Europę francuska chanson filtrowana była przez estetykę niemieckich tingel-tangli i do Polski dotarła w zwulgaryzowanej postaci (Przesmycki 1966: 114-117). Niezależnie jednak od opinii na temat możliwej roli nadsekwańskiego wzorca w kształtowaniu europejskiej kultury, większość odwiedzających na początku XX wieku stolicę Francji Polaków chciała zbliżyć się do tajemnicy paryskiej piosenki, będącej „jednym z nieprzerwanych oddechów takiego jak Paryż olbrzyma" (Lorentowicz 1924: 1), „zakończeniem każdej bezwarunkowo sprawy” i konieczną pointą paryskiego życia (Makuszyński 1909: 6).

\section{Na piosenki - do Paryża}

Od roku 1900, gdy Tadeusz Boy-Żeleński po raz pierwszy odwiedził Paryż, w czasie każdego kolejnego pobytu w tym mieście pierwsze kroki kierował zawsze na Montmartre — „na piosenki” (Boy 1958, t. 16: 140) kabaretowe, które były dla niego swoistym pulsem chwili, pozwalały rozpoznać aktualne zamiłowania i uprzedzenia paryżan. Autor Stówek miał przy tym melancholijną świadomość, że prawda piosenki kryje się w jej przemijalności, nietrwałości i jednoczesnej możliwości ponownego odnalezienia sensu w nowej reinterpretacji dostosowanej stylem do potrzeb teraźniejszości. Nie ufał formowaniu się poglądów na temat kabaretowej piosenki na podstawie incydentalnych doświadczeń. Te ostatnie prowadziły najczęściej do utrwalania mitu paryskich kabaretów, jak miało to miejsce w felietonie Kornela Makuszyńskiego ${ }^{2}$, albo do rozczarowującej weryfikacji legendy, co przydarzyło się Gabrieli Zapolskiej, gdy w roku 1889, za namową Charles'a Auberta, wybrała się do Le Mirliton, by posłuchać śpiewu słynnego nadsekwańskiego apasza — Aristide’a Bruanta. Tak zwierzała się ze swych oczekiwań w Listach paryskich:

Przez całą drogę z teatru Château d'Eau na bulwar Rochechuarta, przy którym mieści się Cabaret du Mirliton, myślałam o tym poecie bruku, śpiewaku obdartusów i nędzarzy, zanurzającym swe dłonie w całą masę łachmanów, stanowiących podstawę Paryża i wyciągającym z tryumfalną pieśnią najstraszliwszy łachman smutku i niedoli, i z łachmanem tym jak z całunem idącym naprzód, niby wiodąc defiladę gueux słaniających się przed widmem nędzy-reginy. I wszystko tam jest w tych pieśniach Bruanta, ta korupcja i zgnilizna proletariatu, gnieżdżącego się jak masa skłębionego robactwa w cuchnących pasażach przedmieść zarogatkowych, płacz nieprawych i opuszczonych jak szczenięta dzieci, jęk znieważonej dziewczyny, szept zgłodniałej kobiety, blask migających noży, tęsknota serdeczna zamkniętej za kratą nędzarki, szczęk zębów zmarzniętego

2 Na opublikowany felieton Kornela Makuszyńskiego Kabaret paryski (Makuszyński 1909: 6-7) powołują się często historycy teatru, chcąc przekonać czytelników o magii pierwszego paryskiego kabaretu Chat Noir — por. Ignaczak 2016: 301. 
żebraka — słowem całe nieszczęście tych, którzy niewinni a wiecznie głodni do trumny się kładą, którzy od Montmartre’u aż do Glaciery idą zbitym szeregiem doskonale wyćwiczonego legionu - wiecznie gotowego do apelu zbrodni, z nerwami tańczącemi ciągłą sarabandę, z kurczem pustego żołądka, z próżnią w mózgu i czerwoną płachtą przed przesyconym absyntem wzrokiem. Bruant — to śpiewak tych, którym Republika nie dała nic, prócz ciągłych na murach napisów, głoszących jak dzwon pusty: równość i braterstwo - a w istocie dozwalających tylko użyć tej równości na zimnych płytach Morgi, lub w zielonych, tłustych falach Sekwany. Bruant śpiewa nędzę i jak kochanek wierny ten blady, cuchnący szkielet wciąż za sobą wiedzie. Łańcuchem pieśni skuł się z nędzą tą szarą na wieki [...]. (Zapolska 1892: 135-136)

Stworzonego na podstawie znajomości tekstów, wyimaginowanego pieśniarza Zapolska nie odnalazła w Le Mirliton. Uderzyła ją panująca tam „nieokreślona atmosfera przygniatającego ogłupienia”: „Kelnerzy roznosili boki, stukali spodkami, goście krzyczeli, wyli, pluli, wymyślali”, a Bruant, nie zważając na to, „śpiewał ciągle z przymkniętemi oczami” (Zapolska 1892: 135-136). Zapolska nie skrywała przed czytelnikami "Przeglądu Tygodniowego” przykrości, jaką wywołał w niej widok tego oferującego „komizm zdetronizowanego talentu” „pajaca przebranego w strój ordynarny i nieartystyczny” (Zapolska 1892: 135-136), który po występie sprzedawał zebranym papierowe fleciki i wiszące na ścianach obrazy, gdy równocześnie kelner obchodził klientów, zbierając datki do podsuwanej im ostentacyjnie miseczki. Wydaje się, że Zapolska nie wychwyciła persyflażowych tonów w Bruantowskich piosenkach, nie uznała, by zachowanie gospodarza było przekonującą formą artystycznej prowokacji — odebrała owo zdarzenie wprost jako frymarczenie cudzą nędzą.

Boy nie mógłby wdać się z Zapolską w dyskusję na temat interpretacji stylu Bruantowskiego pieśniarstwa, ponieważ kabarety paryskie poznawał znacznie później, gdy Le Chat Noir i Le Mirliton pozostały już tylko w legendzie. Ciekawiła go też, przeciwnie niż Zapolską, nie mityczna wyjątkowość piosenki kabaretowej, ale jej organiczna swoistość, specyfika. Dlatego gdy przyjeżdżał do Paryża, niespokojnie krążył po Montmartrze, zaglądając do: Le Grillon i Les Noctambules, Les Quat'z’Arts, La Bôite à Fursy, La Lune Rousse, Le Lapin Agile, zachłannie poszukując w pieśniarskiej miniaturze i jej scenicznym wykonaniu takiego rozbudzenia emocji, z którego wyrasta potrzeba powtórzenia owego doświadczenia (Boy 1958, t. 16: 82-88). Niejednokrotnie odczuwał rozczarowanie ekshumowaniem dawnego repertuaru (Boy 1958, t. 16: 86), rozumiał jednak, że dla ocalenia żywotności utworów słowno-muzycznych potrzebne jest odnalezienie dla nich właściwej współczesności tonacji i stylistyki. Intuicyjnie też przeczuwał, że siła oddziaływania paryskiej piosenki ma swoje źródło w muzycznej tradycji kultury francuskiej, w której ten gatunek jest „jedną z elementarnych potrzeb 
egzystencji, artykułem spożywczym tak ważnym i niezbędnym jak wino i mąka” (Boy 2004: 149). Warto więc spenetrować historyczne źródła, by zrozumieć, na czym polegał rytm krwiobiegu pieśniarstwa francuskiego i w jakim zakresie twórcy pierwszych polskich kabaretów mogli wykorzystywać jego specyfikę.

\section{Les goguettes, czyli czego Polacy nie wiedzą o franuskiej piosence kabaretowej}

Zanim XIX-wieczny paryski kabaret artystyczny uczynił z piosenki spoiwo wystawianych tam programów — operujących niebywałym bogactwem form: takich jak opowieści swawolne, historie nasycone czarnym humorem albo komizmem funeralnym, powiastki, których zakończenie należało do czytającego, enigmatyczne anegdoty o ambiwalentnym zakończeniu (por. Pillet 1992: 48) — funkcjonowała ona w niebywale dynamicznym, zorganizowanym społecznym obiegu, jakiego w Polsce nie zaznaliśmy i którego w gruncie rzeczy do dzisiaj nie znamy.

Tradycję francuskich towarzystw śpiewających cechuje zadziwiająca historyczna ciągłość i dynamika, przy paradoksalnej efemeryczności poszczególnych grup. Pierwszą znaną kompanią śpiewającą była ta stworzona w roku 1323 przez siedmiu tuluzyjskich trubadurów spotykających się w miejskim ogrodzie, by recytować i śpiewać swoje kompozycje (Duboul 1901, t. 1: 19; por. Nisard 1867). Nie była to jeszcze grupa działająca na zasadach późniejszych les goguettes, ale już w niej zaznacza się cecha charakterystyczna dla późniejszych stowarzyszeń śpiewających — były to nieformalne spotkania aranżowane w przestrzeni publicznej z pobudek całkowicie bezinteresownych.

Jak objaśnia Lionel Richard, w starym słowie gogue 'wesołość, żart' — zawiera się podstawowy cel organizowania takich rozśpiewanych spotkań — pragnienie wywołania dobrego humoru zebranego towarzystwa (Richard 1991: 24). Nazwa la goguette będzie używana w kilku zakresach znaczeniowych: jako wskazanie wesołego nastroju wspólnotowej zabawy, nazwa towarzystw śpiewających, mających epikurejski i libertyński charakter, termin odnoszony do konkretnych spotkań śpiewających, organizowanych zgodnie z zasadami danego towarzystwa ${ }^{3}$, oraz kategoria gatunkowa pozwalająca zaklasyfikować konkretne piosenki, uznane za reprezentatywny repertuar dla spotkań śpiewających danej grupy ${ }^{4}$.

Od roku 1729, gdy powstało towarzystwo La Société du Caveau, uznawane za prototyp la goguette, w niezwykle szybkim tempie zaczęło przybywać zgroma-

\footnotetext{
3 Sposoby organizowania les goguettes w różnych okresach historycznych opisywane były wielokrotnie - patrz Paris chantant 1845; Imbert 1873; Imbert 1880: 42.

4 Większość repertuaru śpiewanego w czasie les goguettes należała do pamięci oralnej, piosenki tego typu zyskiwały życie poprzez kolejne ośpiewanie. Nie znaczy to jednak, że nie
} 
dzeń, dzięki inwencji których ta praktyka świętowania zyskała tak różnorodną postać. W latach 1818-1900, wśród towarzystw organizowanych przeważnie w miastach i na przedmieściach, przytrafiały się les goguettes całkowicie apolityczne, kultywujące repertuar anakreontyczny, bachiczny, ale też takie, które wykorzystywały kolejne spotkania dla zamanifestowania poglądów antymonarchistycznych, anarchistycznych 5 .

Każde, liczące nie więcej niż 20 osób $^{6}$, stowarzyszenie tego typu tworzyło również własne reguły spotkań i rytuały potrzebne dla podkreślenia pożądanych cech owej śpiewającej zbiorowości. Większość z nich sięgała po typowe dla goguette rozwiązania: śpiewano dobrze znane piosenki i dla uporządkowania wieczoru wyznaczano prezydenta (maître goguettier) takiego zgromadzenia, który zapisywał i porządkował kolejność wspólnie wykonywanych utworów, trzykrotnym klaśnięciem witał śpiewaków, zbierał z sali propozycje wyrazów, które miały być wykorzystane w powstającej ad hoc piosence. Zróżnicowanie takich towarzystw wyrażało się już w samych nazwach — jedne wskazywały na miejsce, w którym odbywały się spotkania (Société du Caveau ${ }^{7}$, Caveau moderne, Caveau Lyonnais, Caveau de la République), inne — zwłaszcza te o satyrycznym profilu — korzystały z ezopowego kostiumu (np. La Ménagerie, Les Animeaux, La goguette des Insectes), który miał z jednej strony eksponować zwierzęcość instynktów rządzących życiem ludzkim w pozornie tylko cywilizowanym świecie, z drugiej - pozwalał na alegoryczne wyrażenie krytyki społecznej (Paris chantant 1845: 27-28). Według Julesa Vinçarda les goguettes były pierwszym etapem rozwoju „inteligencji popularnej” (Trihoreau 2010: 46).

Ponieważ praktyka tworzenia amatorskich grup śpiewających stała się powszechna, stowarzyszenia takie szukały przyjaznych miejsc w przestrzeni publicznej, w których można byłoby w sposób nieskrępowany współbiesiadować i śpiewać. Piwnice, tawerny, kawiarnie i kabarety w naturalny sposób stopniowo

drukowano ich w odrębnych zbiorach — np. Chansons nationales, nouvelles et autres 1826: 330; La goguette chansonnier de table et de société 1834; La Goguette ancienne et moderne, choix de chansons nationales, guerrières, bachiques, philosophiques, joyeuses et populaires 1865.

5 Gaetano Manfredonia szczegółowo analizuje sytuację les goguettes w latach 20. XIX wieku (porównuje twórczość Pierre-Jeana Bérangera z pieśniarstwem Émile’a Debraux) — patrz Manfredonia 1997: 28-35.

${ }_{6}$ Towarzystwa takie mogły mieć charakter mieszany (mężczyźni, kobiety i dzieci), ale nierzadko założyciele uciekali się do formy wykluczenia - powstawały wówczas grupy wyłącznie kobiece, męskie albo środowiskowe (tylko artyści, tylko prawnicy).

7 Tradycja spotkań w paryskich piwnicach wymaga odrębnego opisu, więc wyłączam to zagadnienie z niniejszego artykuły, wskazując tylko możliwość porównawczego ujęcia tej francuskiej kulturowej tradycji w odniesieniu do polskich doświadczeń, które wydają się nawiązywać do owej formuly (np. Piwnica pod Baranami) - patrz Paris et ses quartiers, Chansons par les membres du caveau 1883; Avenel 1890; Lugnier 1913; Level 1988. 
przejmowały funkcje owych towarzystw, które pod wpływem nadmiernego policyjnego nadzoru stopniowo wygaszały swą działalność.

W paryskich kabaretach przełomu lat 80. i 90. XIX wieku wielokrotnie organizowano autentyczne les goguettes, przypominając o pokrewieństwie celów stawianych sobie przez kabarety i towarzystwa śpiewające. W 1883 roku Jules Jouy zorganizował w Cabaret des Assassins bankiet o takim właśnie charakterze pod szyldem La Soupe et le Boeuf (Herbert 1967: 88).

W roku 1892 kilkakrotnie zapraszano na les goguettes do kabaretu Le Chat Noir (spotkanie, któremu przewodniczył Horace Valbel zostało utrwalone na rysunku Alfreda Le Petit — patrz Valbel 1885-1905: 79). Za wybitnego goguettiera uchodził właściciel kabaretu Le Mirliton, Aristide Bruant (Valbel 1885-1905: 66).

Z tradycji zwierzęcych goguettes można wywieść nazwy wielu kabaretów: Le Chat Noir ('Czarny Kot'), Le Chien Noir ('Czarny Pies'), Le Grillon ('Świerszcz'), L'Âne Rouge ('Rudy Osioł'), Les Éléphants ('Słonie'). Wydaje się też, że tak lubiana w kabaretach aluzyjna, ezopowa gra dwuznacznością również stąd czerpała inspirację . Poza tym les goguettes i kabarety łączyła także strukturalna labilność, wyjątkowa łatwość do przekształcania się i unicestwiania, z czego wynikała też niebywała ruchliwość, wielostronna aktywność tych, którzy tworzyli tego typu artystyczne programy. Wreszcie z owego amatorskiego muzykowania goguettierów wyrosła niewątpliwie niezwykła postać fin de siècle’owego chansonniera. Ten wielostronny obieg piosenki francuskiej znika najczęściej z pola widzenia polskich badaczy form kabaretowych, a przecież to osmoza różnych poziomów życia muzycznego we Francji, polegająca na przenoszeniu repertuaru ulicznego do les goguettes, stamtąd do les cafés chantants i les cafés-concerts, a potem do kabaretów, organizujących les goguettes, zadecydowały o tym, że w przekonaniu Francuzów cała literatura zaczyna się od piosenek (Herbert 1967: 9). Ta wielowiekowa tradycja upowszechniania pieśni jako gatunku kulturowo uprzywilejowanego była niemożliwa do odtworzenia w niestabilnych geopolitycznie i społecznie polskich warunkach.

8 Znamienne, że rysownicy ilustrujący działalność chansonnierów kabaretowych często sięgali po alegoryczność w portretach artystów kabaretowych — np. na rysunkach Alfreda Le Petit, włączonych do kroniki Horace’a Valbela, przedstawiane twarze przypominają ptasie bądź zwierzęce głowy. Ptasi wizerunek samego Valbela (Valbel 1885-1905: XX) znajdujemy więc w Przedmowie, małpia karykatura Pierre'a Trimouillata towarzyszy charakterystyce jego działalności kabaretowej (37), Jean Varney zyskuje oblicze pumy (73), Victor Meusy - papugi (157), a Rodolphe Salis zostaje Orłem Montmartre’u (61). 


\section{Chansonnierzy z Montmartre'u a polscy twórcy kabaretowych piosenek}

Powracający regularnie do kabaretów paryskich Tadeusz Boy-Żeleński wielokrotnie zadawał sobie pytanie: na czym polega nieopisywalność fenomenu nadsekwańskiej chanson? Nie mógł przy tym nadziwić się, że „Ta sama prawie publiczność słuchała wciąż tych samych piosenek, które umiała na pamięć, śpiewanych przez ludzi, których zasoby wokalne były nader wątpliwe." (Boy 1958, t. 16: 83). A jednak wracano, by posłuchać ich po raz kolejny.

Niepowtarzalną dyspozycją paryskich artystów kabaretowych była ich gotowość do łączenia różnych funkcji: autora tekstu, muzyki i wykonawcy. Ta właściwość mieści się w nazwie chansonnier 'szansonista', w polskiej kulturze odnoszonej przede wszystkim do osoby śpiewającej na scenie i to raczej miernie. Jeśli zajrzymy do stworzonej przez jednego z poetów Montmartre'u, Leona de Bercy, kroniki Montmartre et ses chansons: poètes et chansonniers / Montmartre i jego piosenki: poeci i chansonnierzy (de Bercy 1902) oraz pracy Horacego Valbela charakteryzującego channsonierów La Butte (Valbel 1885-1905), to odsłoni się przed nami niebywała rozmaitość ukierunkowań tematycznych i stylistycznych utworów paryskich pieśniarzy kabaretowych.

Młodziutki Mac Nab (de Bercy 1902: 7) pisał piosenki inspirowane twórczością Baudelaire’a i Poego, czarując słuchaczy makabryczną elegijnością, czego zapowiedzią jest początek choćby takiej strofy:

Un jeune homme venait de se prendre

Dans la forêt de Saint Germain

[Pewien młody człowiek właśnie powiesił się

W lesie Saint Germain]. (Boy 2004: 151)

a oprócz tego składał reklamowe kuplety przeznaczone dla fabryki produkującej piecyki grzewcze; Hector Ganier (de Bercy 1902: 8-9) specjalizował się W „odświeżaniu” starych prowincjonalnych piosenek; mający niebanalnie brzmiący głos Hector Sombre (de Bercy 1902: 10-11) trwonił go, dostosowując styl wykonania do marnych utworów, byle tylko zaspokoić oczekiwania publiczności; René Ponsard, podobnie jak Aristide Bruant, Jean Richepin czy Jehan Rictus, pisząc w języku argot, mieszał szyderstwo z sentymentalną słodyczą (de Bercy 1902: 11); Vincent Hyspa, egzotycznie ubrany w tureckie pantalony i perski surdut, śpiewał „stłumionym głosem” piosenki parodystyczne w tonacji burleskowej (de Bercy 1902: 84-87); Paul Paillette, o twarzy rabelaisowskiego proboszcza, niezmiennie prowokował hasłami anarchistycznymi (de Bercy 1902: 91-95); akompaniując sobie na pianinie, Léon Xanrof wykonywał swego Fiakra w duecie z papugą — amazonką (de Bercy 1902: 91-95; Valbel 1885-1905: 
34, 36); Georges Fragerolle własne kompozycje podawał wibrującym, metalicznym białym głosem (de Bercy 1902: 41-44), a Antoine Brun czarował ciepłym, przejmującym, niskim brzmieniem, zaskarbiając przychylność publiczności romansami: Fou, Amor, Nos Démons, czy Ma Promise (Valbel 1885-1905: 126-127); konkurencją dla tego ostatniego był śpiewający równie głębokim barytonem Marcel Legay, który zanim stał się chansonnierem Czarnego Kota, dał się poznać mieszkańcom Montmartre’u jako uliczny śpiewak, akompaniujący sobie na harmonii (de Bercy 1902: 19-30; por. Poole 1994; Bertrand 2015).

To zestawienie, potwierdzające, że istotnie Le Chat Noir „dławił się od talentów" (Boy 1964a, t. 21: 220), nie jest pełne, ale daje wyobrażenie o tym, co wyeliminowała polska legenda. Nie znalazł się w niej również „śpiewający nikłym suchotniczym głosikiem" (Boy 1958: 82) Paul Delmet (de Bercy 1902: 68-72; por. Valbel 1885-1905: 199-205), autor rzewnych, sentymentalnych melodii do wierszy Henri Bernarda, Théodore’a Botrela (de Bercy 1902: 180-185; por. Valbel 1885-1905: 217-229), Armanda Silvestre'a. Jednak to walory jego muzyki wykorzystywane były najczęściej przez twórców polskiego kabaretu. Tadeusz Boy-Żeleński do melodii piosenki Petit chagrin stworzył w roku 1907 zielonobalonikową persyflażową Piosenkę przekonywująca (Boy 2004: 195-197; por. Adrjański 1997: 220), melodię Les petit pavés przydał piosence Kaprys (Boy 2004: 87-88), prymką Exil d'amour posłużył się w dwugłosie filozoficznym Piosenki megalomana (Boy 2004: 89-90), natomiast na kanwie melodycznej Envoi de fleurs ${ }^{10}$ zbudował Piosenkę sentymentalna, której nie trzeba brać zanadto serio (Boy 2004: 184-185), a znów do programu Momusa w roku 1909 włączono jego Piosenke wzruszajaca (Boy 2004: 209-211; por. Adrjański 1997: 221-222) do melodii Fleurs et pansées ${ }^{11}$. Podobnie kontrafakturowo wykorzystał melodię Delmeta Lucjan Konarski w piosence: Czy kochasz mnie? - wykonywaną w kabarecie Momus w 1911 roku (Karwacka 1982: 70, 150) ${ }^{12}$. Na tej samej zasadzie zwią-

\footnotetext{
${ }^{9}$ Słowa do piosenki Petit chagrin / Smuteczek napisał Maurice Vaucaire - patrz Chansons de Paul Delmet b.d: 14-20.

${ }^{10}$ Stowa piosenki - Henri Bernard.

${ }_{11}$ Piosenka opublikowana w zbiorze: Vingt chansons d'amour et de bohême par Paul Delmet 1907 [Ta violette. Parisienne, Berceuse d'amour, Chanson du matelot, A tes yeux, Tu me disais!, A la chanson méchante, vous le savez bien!, Fleurs et pensées, Noël d'amour, Ce que j'aime, Chanson de folle. Quand tu s'ras grand [...], Les Becs salés, Mon aimée, Le Vieux prunier, L'Amour à travers les âges, Chemin fleuri].

12 Wydaje się, że za Boyem autorka podaje słynny Biaty pokoik Konarskiego jako piosenkę do muzyki Delmeta; a może badaczka niewłaściwie zinterpretowała słowa publicysty Stefana Krzywoszewskiego, który charakteryzując repertuar Momusa („Świat” 1909) napisał, że piosenka ta „sentymentem najlepsze utwory Delmeta” przypomina (?) — patrz Rudzki, red. 1957: 159; przypisanie przez Boya Biatego pokoiku Delmetowi próbował dementować Arnold Szyfman w artykule Momus warszawski (Rudzki, red. 1957: 146) — por. Adrjański 1997: 222.
} 
zano muzykę Leona Xanrofa z momusową piosenką Wspomnienie autorstwa Leona Choromańskiego (Karwacka 1982: 130) .

Jaką funkcję pełniła piosenka w Le Chat Noir i Le Mirliton? Była niewątpliwie kroniką środowiskową i żywym „komentarzem egzystencji we wszystkich jej przejawach"13. Między innymi służyła rejestrowaniu kabaretowego życia w śpiewanych scenkach rodzajowych i portretach. W wierszowanych nuconych komplementach celował Gaston Sécot, to przedstawiając Delmeta jako pieśniarza o wybornym głosie, to zachwalając Trimbouillete’a jako twórcę „bez skazy”, podkreślając u Xaviera Privas ciekawe połączenie drapieżnego wykonania z elegancją opowieści miłosnych, w Georges'u Tiercy’m dostrzegając zaś „profesora mimiki” (de Bercy 1902: 18-19). Obok zwięztych charakterystyk proponowano też bardziej szczegółowe a uszczypliwe wizerunki, podobne temu, który miał być odpowiedzią na wzniosłość soliloquiów Jehana Rictusa, a wyszedł spod pióra spółki: Theodor Botrel, Dominik Bonnaud i Numa Blés. W zaproponowanej przez nich autoprezentacji sceniczny Rictus przeciwstawiał się tym, którzy ośmielali się nazywać go „Jésus Christ dentiste” (de Bercy 1902: 175).

W twórczości pierwszych polskich kabaretów: Zielonego Balonika, Figlików czy Momusa nie brakuje podobnych śpiewanych portretów, w większości sytuacyjnych. Takim utworem była parodiująca Kanconę Dyla Sowizdrzata, autorstwa Nowaczyńskiego, piosenka komentująca powstanie Figlików (1907), a odnosząca się do działań dwu ważnych dla życia teatralnego postaci: Arnolda Szyfmana i Ludwika Solskiego ${ }^{14}$. Słynne były też kuplety Noskowskiego zatytułowane Nie widziat kto Karola Frycza gdzie?, w których autor dworował z niesłowności i braku punktualności świetnego zielonobalonikowego scenografa ${ }^{15}$. Nie sposób jednak udowodnić, że owa analogia wynika z bezpośredniego wpływu paryskich kabaretów.

Oprócz piosenek rejestrujących kabaretową codzienność, Montmartre śpiewał, co przewidywalne, o miłości i miłostkach. Skala odcieni nastrojów tego typu utworów była nader bogata: od tonacji czysto sentymentalnej kompozycji Delmeta, przez zmysłowość piosenek Montoi (de Bercy 1902: 96-102), o którego tekstach pisano, że nie ma w nich niczego poza kwiatami, perfumami, wietrzykiem, błękitem nieba, westchnieniami i pocałunkami, ale kwiaty są odurzające, a pocałunki namiętnie bolesne (Valbel 1885-1905: 114); przez

${ }^{13}$ Stwierdzenie Borisa Viana — cyt. za: Dutheil Pessin, 2004: 27 (tłumaczenie L.I.).

${ }_{14}$ Balladę o Kasztelanie i Sowizdrzale, autorstwa Boya i Nowaczyńskiego, odśpiewał Teofil Trzciński w Drugiej Szopce Zielonego Balonika — patrz Karwacka 1982: 60; por. Kuchtówna 2004: 93-94.

${ }^{15}$ Linia melodyczna piosenki pochodziła z przeboju Antona Ronachera, dyrektora wiedeńskiego teatru Varieté Haben Sie den kleinen Kohn nicht gesehen? — patrz Kuchtówna 2004: 89-91. 
frywolność kupletów w rodzaju: „Kiedy król Grecji po swawoli opuszcza buduar damy z półświatka, nie warto ścielić łóżka — król Leopold przychodzi zaraz po nim"16; po gorzką, złą, melodramatyczną miłość przedstawioną choćby w Sercu matki Richepine' ${ }^{17}$.

Obok chanson d'amour występowała chanson sociale. Piosenkami atakowano niesprawiedliwości systemu i historii, wykorzystując do tego wszystkie rejestry stylistyczne: od sentymentalnego, przez melodramatyczny, satyryczny, po odmianę - którą Catherine Dutheil Pessin (zgadzając się w tym względzie z André Velterem) uzna za najbardziej oryginalną i charakterystyczną dla kabaretów XIX wieku - operującą makabrycznym humorem, będącym środkiem frenetycznego ośmieszania (Dutheil Pessin 2004: 33; por. Velter 1996: 11). Według diagnozy A. Veltera, wisielczy śmiech i obelga słowna były ucieczką przed strachem wyzwolonym i spotęgowanym przez zdarzenia Komuny Paryskiej, były sposobem na przetworzenie egzystencjalnych lęków (Velter 1996: 11). Przykładem kontestującego autora, którego Léon de Bercy nazwał „królem pieśniarzy”, był Jules Jouy. Ten współpracownik paryskich gazet socjalistycznych chętnie wykorzystywał formę piosenki jako pamflet społeczno-polityczny, czego przykładem może być, dedykowana Emilowi Zoli, piosenka La Terre ('Ziemia'), czy inna, zatytułowana La Veuve (w argot: 'Szubienica'), będąca przejmującym wystąpieniem przeciwko karze śmierci (Dutheil Pessin 2004: 33).

Takiej powagi i pasji we wskazywaniu mankamentów systemu, czy manifestowaniu anarchistycznych poglądów, jakie zaprezentują artyści Le Chat Noir i Le Mirliton (wymieńmy tu: Paillette’a czy Rictusa), nie znajdziemy w piosenkach pierwszych polskich kabaretów.

Ale też od tego rodzaju otwartych rozliczeń uchylał się nie kto inny jak Aristide Bruant. Niegdyś butnie rzucający w tłum słowa: „Jam republikanin, socjalista, / zwolennik skrajnej lewicy, / Rewolucjonista, anarchista” (cyt. za: Appignanesi 1990: 34) stopniowo przyjął poglądy konserwatywne, tonując

${ }^{16}$ Quand le roi de Grèce après une fredaine

Quitte le boudoir d'une demi-mondaine,

Ça ne vaut pas la peine de refaire le lit -

Le roi Léopold arrive après lui...

Piosenkę śpiewano „na starą operową nutę” o inc. „T’en souviens-tu, quand t'étais prince de Galles” („Pamiętasz, jak byłeś księciem Galii”), która to melodia znana była Polakom w czasach międzywojnia za sprawą połączenia jej z niemieckim tekstem Tysiąc walecznych — patrz Boy 1965: 165 .

${ }^{17}$ Ta stylizowana na bretońską balladę piosenka powstała w 1883 roku, a stanowi finał powieści Jeana Richepina $L a$ Glu, muzykę napisał do niej Charles Gounod (była też wersja dramaturgiczna tej historii) — patrz Richepin 1881: 344-345. Piosenkę tę wykonywano też w repertuarze Le Chat Noir, ale z muzyką Georgesa Fragerolle’a. Utwór ten do swojego repertuaru włączyła Yvette Guilbert — patrz Oberthür 2007: 164, 166. 
swoje kabaretowe wystąpienia. Nie oznacza to jednak, że ballady śpiewane przez gospodarza Le Mirliton nie odsłaniały rewersu La Belle Ėpoque, przekonywała Louise Rypko-Schub. Badaczka analizując pojawiające się w piosenkach Bruanta motywy tematyczne, łącznie z językowym kształtem utworów, doszła do wniosku, że przy wszelkich uproszczeniach wynikających ze skrótowości prowadzącej do stereotypizacji obrazu, piosenki Bruanta są — jak zalecał Zola — dokumentacyjną opowieścią o tych, którzy w sposób niezawiniony zostali wykluczeni ze społeczeństwa (Rypko Schub 1976: 196). Jest to zaproszenie do świata - co doceniali także polscy artyści, tacy jak Adolf Nowaczyński — „tych bez ogniska domowego, bez spokoju, bez szczęścia, bez etyki mieszczańskiej, tych spoza solidnego obywatelskiego parkanu, tych żyjących z dnia na dzień wykolejeńców, filistrów próżniactwa, stoików bulwarowych, alkoholików” (cyt. za Kiec 2004: 9). Catherin Dutheil Pessin podkreślała, że są to bohaterowie, w których nigdy nie dojrzeje oczyszczający bunt. Dlatego otoczeni są sentymentalnym autorskim współczuciem, które będzie podstawą słowno-muzycznego mitu środowiska szumowin społecznych (Dutheil Pessin 2004: 36).

Boy z podziwem konstatował, że z piosenek Bruanta, takich jak $\mathrm{Na}$ ulicy, $\mathrm{Na}$ gościńcu, W Lasku w Vincennes można ułożyć swoisty atlas La Butte, bowiem ich autor, nie pomijając żadnej dzielnicy Paryża, utrwalał w nich „i szynk podmiejski, i więzienie, i szpital, i kolonie karne, i ostatni etap tych egzystencji — gilotynę" (Boy 1964a, t. 21: 220; por. Frey 2004).

Polscy artyści kabaretowi próbowali przybliżyć ten nurt piosenki społecznej najpierw publiczności Momusa (1909), włączając do programów parafrazy Leona Schillera: Starego żebraka Paula Delmeta i Nóż / Balladę o wtóczędze Theodora Botrela (Karwacka 1982: 133); później w roku 1918 widzom kabaretu Miraż, dla którego z kolei Julian Tuwim przygotował tłumaczenia piosenki Aristide'a Bruanta Na szubienicy ${ }^{18}$ i ballady bretońskiej Jeana Richepine’a Serce matki ${ }^{19}$. Czyniąc to mieli jednak świadomość, że wszczepienie paryskiej piosenki in crudo do polskiego repertuaru kabaretowego byłoby krokiem fałszywym, ponieważ znalazłaby się ona wobec publiczności, dla której formy słowno-muzyczne nie potwierdzają jakości życia zbiorowego, jak ma to miejsce w kulturze francuskiej.

${ }_{18}$ Tekst wydrukowany w „Estradzie” 1918, nr 8 (Utwory Jana Wima i innych), s. 18-20; przedrukowany w: Groński 1994: 15-16.

${ }^{19}$ Tekst opublikowany w „Estradzie” 1918, s. 9-10; piosenka przypomniana w czasie Koncertu dawnych utworów rozrywkowych z okazji 50-lecia ZAiKS-u w wykonaniu Hanki Skarżanki — patrz Głowacka, red. 1981: 40; włączona na stałe w krwiobieg teatralny jako element sztuki Witkacego Matka — prem. 20 VI 1970 r., Warszawa, Teatr Współczesny, reż. Erwin Axer — program teatralny:http://www.witkacologia.eu/teatr/Witkacy_na_scenach_polskich_2. html\#rok1970; archiwumhttp://www.e-teatr.pl/pl/programy/2013_11/52206/matka_teatr_wspolczesny_warszawa_1970.pdf [dostęp: 8.01.2017]. 
Arnold Szyfman przekonywał - podobnie jak przed nim robił to Jan August Kisielewski (Kisielewski 1966: 120-124), że ponieważ „dla nas piosenka nie jest chlebem powszednim" tak jak we Francji, dlatego polski kabaret powinien rozwijać się przede wszystkim na rodzimym gruncie (Szyfman 1909: 51).

Jeśli więc korzystano w kształtowaniu repertuaru kabaretowego ze wzorca Le Chat Noir i Le Mirliton, to najczęściej przetwarzając go parodystycznie, jak zrobił to Schiller w swoich miniaturach słowno-muzycznych: Brzydkiej kochance, Wiatr za szybami czy Piosence ${ }^{20}$.

Nawet wówczas, gdy w kabaretach wykorzystywano środki obrazowania, które były typowe dla piosenki paryskiego fin de siècle'u, nawet gdy piosenką kabaretową przypominano o sprawach ostatecznych, jak choćby w naturalistycznym Tańcu brzucha Bogusława Adamowicza:

W trupie szpik wyżre śmierć, próchno zje kości.

Robak w stęchłym szkielecie stoczy wnętrzności. (Rudzki, red. 1957: 122);

czy w bachicznej strofie noir (Wiatr za szybami):

Co chcesz, świętoszku, sobie twierdź -

My chlajmy do finału dramy,

Aż gasząc światło krzyknie śmierć:

„Fajerant” — lokal zmykamy. (Rudzki, red. 1957: 120);

albo w wykorzystującym motyw danse macabre refrenie: „zasypie wam źrenice piach”, piosenki Władysława Nawrockiego, wzorowanej na utworze Marcela Legay $^{21}$ (Karwacka 1982: 100), brzmią już one z pewnego dystansu narzuconego teatralną stylizacją, stając się melancholijną reprezentacją przeszłości pierwszych paryskich kabaretów, tak w historycznym, jak i mitycznym wymiarze.

\section{Podsumowanie}

Wydaje się, że tylko pierwszych dziesięć lat XX wieku było czasem owych praktycznych usiłowań, by pieśniarską tradycję kabaretu francuskiego wykorzystać w tworzeniu repertuaru polskich nadscenek. Już wówczas jednak można wskazać pewne interpretacyjne nieścisłości świadczące o tym, że sporo racji kryje

${ }^{20}$ Ich obecność w repertuarze Momusa zarejestrowała Helena Karwacka (Karwacka 1982); teksty można znaleźć w: Rudzki, red. 1957: Wiatr za szybami 119-120; Brzydka kochanka / Brzydula 169-170; Piosenka 170-171.

${ }^{21} \mathrm{H}$. Karwacka zwraca uwagę na to, że była to piosenka wykonywana w Momusie przez Alfreda Lubelskiego, a jej tekst i melodia szczepione były na motywach utworu Marcela Legay. Dzięki badaniom M.E. Poole nad twórczością tego montmartryjskiego artysty można ustalić, że naśladownictwo dotyczyło piosenki, do której słowa napisał Maurice Boukay, Le grand voyage ou Tu t'en iras les pied devant! (Poole 1994: 512). 
się w ironicznym komentarzu Ryszarda Marka Grońskiego, który uważał, iż „przyznawanie się do wpływów francuskich złożyć trzeba na karb nie wygasłych snobizmów i prób uszlachetnienia genealogii poprzez znalezienie godnych antenatów" (Groński 1987: 20). Często bowiem porównania polskich wykonawców do paryskich artystów kabaretowych były raczej umowne. Momusowy pieśniarz Alfred Lubelski zestawiany był z Aristidem Bruantem, „mimo że styl i charakter uprawianego przez niego pieśniarstwa różnił się od francuskiego pieśniarza" (Karwacka 1987: 1822). Nie próbowano objaśniać, dlaczego w tak odmiennych stylistycznie artystkach jak Adolfina Zimajerer3, Mary Mrozińska (Michalski 2007: 210; por. Kiec 2004: 30; 2014: 53), czy później Hanka Ordonówna (Michalski 2007: 130, 142-143) widziano następczynie Yvette Guilbert ${ }^{24}$.

Wielu z tych, którzy rozsmakowali się w dawnej paryskiej stylistyce wykonawczej, nie potrafiło się jednak pogodzić ze stopniowym, nieuchronnym przeobrażaniem się polskich nadscenek, tym bardziej dotkliwym, gdy sięgano po francuski repertuar. Boy pamiętający, że w Le Chat Noir „kult słowa sięgał tak daleko, iż w stylu ówczesnym wykluczano prawie mimikę; stojąc nieruchomo, z nieubłaganie poważną twarzą" (Boy 1963b, t. 20: 478), nie mógł przystać na to, co zobaczył na scenie Małego Qui Pro Quo w roku 1937. Towarzyszące wykonaniu francuskich piosenek "prysiudy” wydały mu się zaprzeczeniem estetyki pierwszych paryskich kabaretów, wzorca, którego — miał tę świadomość — nie można było już odzyskać (Boy 1970: 330).

Odczuwany przez Boya rozdźwięk między stylistyką dawnej paryskiej piosenki i jej wykonaniem w polskich kabaretach czasów międzywojnia okazał się mniej istotny dla nieubłaganie komercjalizującej się publiczności. Dla niej

22 To porównanie Lubelskiego z Bruantem przenosi do swojej pracy Dorota Fox (Fox 2007: 22).

${ }^{23}$ D. Michalski uważał to porównanie za całkowicie chybione (Michalski 2007: 210).

${ }^{24}$ Wydaje się, że szybciej zatarł się ślad pieśniarskich umiejętności Bruanta, pozostawiając w pamięci przede wszystkim wizerunek barwnie, ekscentrycznie ubranego artysty z plakatów Toulouse-Lautreca. Natomiast wspomnienia o kunszcie scenicznym Yvette Guilbert ożywały jeszcze w czasach powojennych. Choćby we wspomnieniach Bronisława Horowicza, który zapamiętał występ Madame w paryskiej Alhambrze, gdy ta „starsza pani, w skromnej domowej długiej sukni” zaprezentowała utwory właśnie z Le Chat Noir (m.in. Xanrofa, Donnaya) obok pieśni ludowych, ballad i kolęd. „Mogłem stwierdzić, jak trwałe były podstawy jej sztuki, jak bardzo muzykalność i poczucie smaku szły w niej w parze z kunsztem aktorskim" — wspominał Horowicz (Horowicz 1974: 60).

Niezwykłej trwałości legendy tej pieśniarki — przekonuje C. Dutheil Pessin — należy upatrywać w tym, że porzuciła ona kabaret dla estrady wymuszającej zmianę stylu prezentowania piosenki. Przejąwszy repertuar krążący niegdyś w intymnej przestrzeni kabaretów, występowała z nim w cafés-concerts i music-hallach, wypracowując nowy kanon gestów i scenicznych rytuałów zmieniających charakter słów dawnego kabaretowego repertuaru, który niegdyś odnosił się do realiów, a przywołany poza pierwotnym kontekstem, mógł być tylko elementem scenicznego imaginarium współczesności (Duthail Pessin 2004: 38). 
wzorzec paryski pozostał sentymentalnym mitycznym ornamentem programów kabaretowych, które nadal korzystały „z importowanych pomysłów i koncepcji” z Paryża, przetwarzając jednak pożyczony materiał tak dalece, że w rezultacie trudno było w nim odnaleźć pierwotny estetyczny wzór. Przekonują o tym wnioski R.M. Grońskiego odnoszące się do sposobu funkcjonowania polskich teatrzyków kabaretowych w dwudziestoleciu międzywojennym:

Poglądem bez pokrycia jest twierdzenie, jakoby kabaret polski zawdzięczał najwięcej nadscenkom paryskim. Te dostarczały co najwyżej motywów tematycznych. Z kabaretu francuskiego, a i to via Berlin i Wiedeń, przywędrował apasz, sentymentalny włóczęga, panienka lekkiego prowadzenia o złotym serduszku [...]. Największe nasilenie tłumaczeń i przeróbek z francuskiego przypada na okres Czarnego Kota i Mirażu, by później ustać niemal całkowicie. Były to bowiem refleksy kultury wyższej: pozostałości gustów i upodobań salonowej publiki, wśród której znajomość języka France’a była towarzyskim obowiązkiem. [...] W programach pojawiały się od czasu do czasu montaże francuskich piosenek. Zarówno dawnych jak i najnowszych. Nie oddziaływały one jednak znacząco na stylistykę polskiego kabaretu. Rodzaj interpretacji odbiegał całkowicie od paryskich pierwowzorów (Groński 1987: 18-19).

\section{BIBLIOGRAFIA}

Adrjański Zbigniew. 1997. Ztota księga pieśni polskich. Warszawa: Wydawnictwo Bellona.

Appignanesi Lisa. 1990. Kabaret. Przeł. Adam Kreczmar. Warszawa: Państwowy Instytut Wydawniczy.

Avenel Henri. 1890. Chansons et chansonniers. Paris: C. Marpon et E. Flammarion Éditeurs.

Bayard Jean Émile. 1925. Montmartre hier et aujourdhui. Paris: Jouve.

Bercy Léon de. 1902. Montmartre et ses chansons. Poètes et Chansonniers. Paris: H. Daragon.

Chansons de Paul Delmet. B.d. Paris: H. Tellier.

Chansons nationales, nouvelles et autres par Émile Debraux. 1826. Paris: Galerie de Bois.

Deleuze Gilles, Guattari Félix. 2015. Tysiąc plateau. Przedm. Michał Herer. Warszawa: Fundacja Bęc Zmiana.

Delvau Alfred. 1862. Histoire anegdotique des cafés et cabarets de Paris. Paris: E. Dentu.

Donnay Maurice. 2014. Autour du Chat Noir. Paris: Grasset.

Duboul Axel. 1901. Les deux siècles de l'Académie des Jeux floraux. Toulouse: Eduard Privas. 
Dutheil Pessin Catherine. 2004. Chanson sociale et chanson rèaliste. „Cités. Philosophie, Politique, Histoire” 3, nr 19. S. 27-42.

Fox Dorota. 2007. Kabarety i rewie międzywojennej Warszawy. Katowice: Wydawnictwo Uniwersytetu Śląskiego.

Frey Julia. 2004. Toulouse-Lautrec. Przeł. Joanna Andrzejewska. Warszawa: Państwowe Wydawnictwo Naukowe.

Głowacka Helena, red. 1981. Wspomnienia o Kazimierzu Rudzkim. Warszawa: Czytelnik.

Goudeau Émile. 1893. Paris qui consomme. Tableaux de Paris. Paris: Henri Beraldi.

Groński Ryszard Marek. 1987. Jak w przedwojennym kabarecie. Kabaret warszawski 1918-1939. Warszawa: Wydawnictwo Artystyczne i Filmowe.

Groński Ryszard Marek. 1994. Taki byt kabaret. Warszawa: Wydawnictwo PTWK.

Herbert Michel. 1967. La chanson à Montmartre. Paris: La Table ronde.

Horowicz Bronisław. 1974. Nim przeminie z wiatrem. Warszawa: Wydawnictwo Artystyczne i Filmowe.

Ignaczak Lidia. 2016. Tęsknota za Chat Noir i Mirliton. Wokót legendy paryskich kabaretów. „Acta Universitatis Lodziensis. Folia Litteraria Polonica” 3 (33). S. 279-308.

Imbert Eugène. 1880. Galerie de chansonniers: Noël Mouret. „La Chanson: revue mensuelle: archives de la chanson: écho des sociétés lyriques” 19 juin 1880 . $\mathrm{Nr} 6$. Rédacteur en chef: L.-Henry Lecomte. Paris: Librairie ancienne et moderne A. Patay. S. 42.

Imbert Eugène. 1873. La Goguette et les goguettiers, Étude parisienne. Paris: L. Bryois.

Jeske-Choiński Teodor. 1889, Teatry paryskie. „Echo Muzyczne, Teatralne i Artystyczne” nr 308. S. 233-235.

Karwacka Helena. 1982. Warszawski Kabaret Artystyczno-Literacki Momus. Warszawa: Państwowe Wydawnictwo Naukowe.

Kiec Izolda. 2014. Historia polskiego kabaretu. Poznań: Wydawnictwo Poznańskie.

Kiec Izolda. 2004. W kabarecie. Wrocław: Wydawnictwo Dolnośląskie.

Kisielewski Jan August. 1966. Panmusaion. W: Myśl teatralna Mtodej Polski. Wybór: Irena Sławińska i Stefan Kruk. S. 120-127.

Kuchtówna Lidia. 2004. Karol Frycz. Warszawa: Oficyna Wydawnicza Errata.

La goguette, chansonnier de table et de société, par MM. Béranger, Désaugiers, Armand Gouffé, Em. Debraux, L. Festeau, J. Cabassol, Piton, Saint-Gilles, Moreau, Panard, A. Jacquemart, Ch. Le Page, etc., etc. 1834. Paris: Chez tous les marchands de nouveautés. La Goguette ancienne et moderne, choix de chansons nationales, guerrières, bachiques, philosophiques, joyeuses et populaires. 1865. Deuxième édition. Paris: Garnier Frère.

Level Brigitte. 1988. À travers deux siècles, le Caveau, société bachique et chantante, 1726-1939. Paris: Presses de l'Université de Paris-Sorbonne. 
Lorentowicz Jan. 1924. Boy. „Świat” nr 40. S. 1-2.

Lugnier Antonin. 1913. Histoire de la Société lyrique les Enfants du Caveau. Paris: H. Daragon.

Makuszyński Kornel. 1909. Kabaret paryski. „Tygodnik Ilustrowany” nr 1. S. 6-7.

Manfredonia Gaetano. 1997. La chanson anarchiste en France des origines à 1914. Paris: L'Harmattan.

Meusy Victor, Depas Edmond, red. 1900. Guide de l'étranger à Montmartre. Préface d'Emile Goudeau. Paris: J. Strauss.

Michalski Dariusz. 2007. Powrócmy jak za dawnych lat... Historia polskiej muzyki rozrywkowej. Warszawa: Wydawnictwo Iskry.

Montorgueil Georges. 1899. La vie à Montmartre. Paris: G. Boudet, C. Tallandier.

Mościcki Tomasz. 2008. Kochana stara buda. Teatr Qui Pro Quo. Łomianki: LTW.

Nisard Charles. 1867. Des chansons populaires chez les anciens et chez les Français; essai historique suivi d'une étude sur la chanson des rues contemporaine. Paris: E. Dentu.

Nowaczyński Adolf. 1906. Cabaretiasis. W: Wczasy literackie. Warszawa: nakł. Jana Fiszera. S. 153-178.

Nowaczyński Adolf. 1966. Literackie teatrzyki rozmaitości. W: Myśl teatralna Mtodej Polski. Wybór: Irena Sławińska i Stefan Kruk. Warszawa: Wydawnictwo Artystyczne i Filmowe. S. 103-109.

Nowaczyński Adolf. 1918. Rozmirażowanie. „Teatr” nr 2. S. 30-31.

Oberthür Mariel. 2007. Le cabaret du Chat Noir à Montmartre (1881-1897). Genève: Slatkine.

Paris chantant: romances chansons et chansonnettes contemporaines (1845). Texte de Marc Fournier, Fertiault... [et al.]. Musique de Festeau, Scudo, A. Harquerie... [et al.]. Paris: Lavigne.

Pillet Elisabeth. 1992. Cafés-concerts et cabarets. „Romantisme” 1992, nr 75. S. 43-50 [online]. http://www.persee.fr/docAsPDF/roman_0048-8593_1992_ num_22_75_6000.pdf [dostęp: 8.01.2017].

Paris et ses quartiers. Chansons par les membres du Caveau. 1883. Paris: Dentu.

Poole Mary Ellen. 1994. Chansonniers and chanson in Parisian Cabarets Artistique, 1881-1914. University of Illinois at Urbana-Champaign.

Przesmycki Zenon. 1966. Nadsceny. W: Myśl teatralna Mtodej Polski. Wybór: Irena Sławińska i Stefan Kruk. Warszawa: Wydawnictwo Artystyczne i Filmowe. S. 109-120.

Richard Lionel. 1991. Cabaret, cabarets — Origines et decadence. Paris: Plon.

Richepin Jean. 1881. „Y avait un' fois un pauv' gas...” (Serce matki). W: La Glu. Paris: M. Dreyfous. S. 344-345.

Rudzki Kazimierz, red. 1957. Dymek z papierosa, czyli wspomnienia o scenach, scenkach i nadscenkach. Warszawa: Wydawnictwo Iskry. 
Rypko Schub Louise. 1976. La Chanson naturaliste. Aristide Bruante, ou le revers de la Belle Époque. „Cahiers de l'Association internacionale des etudes françaises” nr 28. S. 195-212.

Szyfman Adolf. 1909. Trzeci polski kabaret. „Tygodnik Ilustrowany” nr 3. S. 51.

Thompson Sophy, red. 2012. Autour du Chat Noir. Arts et plaisirs à Montmartre (18801910). Préface Kléber Rossillon, Skira Flammarion. Paris: Musée de Montmatre.

Trihoreau Michel. 2010. La chanson de proximité. Caveaux, cabarets et autres petits lieux. Paris: L'Harmattan.

Utwory Jana Wima i innych. „Estrada” 1918, nr 8. S. 9-20.

Valbel Horace. 1885-1905. Les chansonniers et les cabarets artistiques. Paris: E. Dentu.

Velter André. 1996. Les Poètes du Chat Noir. Paris: Gallimard.

Weiss Tomasz. 1987. Legenda i prawda Zielonego Balonika. Kraków: Wydawnictwo Literackie.

Bertrand Yves. 2015. Le Chansonnier Marcel Legay, Le son d'une belle âme. Paris: L'Harmattan.

Zapolska Gabriela. 1892. Listy paryskie, „Przegląd Tygodniowy” nr 11. S. 135-136.

Żeleński Tadeusz (Boy). 1958. Felietony. W: Pisma. T. 16. Warszawa: Państwowy Instytut Wydawniczy. Śladami piosenki. S. 82-89. «Xenofobia». S.140-146.

Żeleński Tadeusz (Boy). 1963a. Flirt z Melpomena. Wieczór pierwszy i drugi. W: Pisma. T. 19. Wyd. 1. Warszawa: Państwowy Instytut Wydawniczy.

Żeleński Tadeusz (Boy). 1963b. Flirt z Melpomeną. Wieczór trzeci i czwarty. W: Pisma. T. 20. Wyd. 1. Warszawa: Państwowy Instytut Wydawniczy.

Żeleński Tadeusz (Boy). 1964a. Patriarcha piosenki. W: Flirt z Melpomena. Wieczór piąty i szósty. W: Pisma. T. 21. Wyd. 1. Warszawa: Państwowy Instytut Wydawniczy.

Żeleński Tadeusz (Boy). 1964b. Flirt z Melpomeną. Wieczór siódmy i ósmy. W: Pisma. T. 22. Wyd. 1. Warszawa: Państwowy Instytut Wydawniczy.

Żeleński Tadeusz (Boy). 1965. Xanrof i Chancel "Książe matżonek”. W: Flirt z Melpomena. Wieczór dziewiąty i dziesiąty. W: Pisma. T. 23. Wyd. 1. Warszawa: Państwowy Instytut Wydawniczy.

Żeleński Tadeusz (Boy). 1966. Okno na życie. Ludzie i bydlątka. W: Pisma. T. 24. Wyd. 1. Warszawa: Państwowy Instytut Wydawniczy.

Żeleński Tadeusz (Boy). 1968. Reflektorem w serce. Romanse cieniów. W: Pisma. T. 25. Wyd. 1. Warszawa: Państwowy Instytut Wydawniczy.

Żeleński Tadeusz (Boy). 1969. Perfumy i krew. Krótkie spięcia. W: Pisma. T. 26. Wyd. 1. Warszawa: Państwowy Instytut Wydawniczy.

Żeleński Tadeusz (Boy). 1970. Murzyn zrobit.... Wrażeń teatralnych seria siedemnasta. W: Pisma. T. 27. Wyd. 1. Warszawa: Państwowy Instytut Wydawniczy.

Żeleński Tadeusz (Boy). 2004. Stówka. Warszawa: Wydawnictwo Iskry. 
Lidia Ignaczak

\title{
FROM THE LES GOGUETTES TO CABARETS - ABOUT THE RELATIONSHIP BETWEEN A FRENCH AND POLISH CABARET SONG IN THE YEARS 1881-1911
}

\author{
(summary)
}

The article deals with the problem of the historical transformation of French and Polish cabaret songs at the turn of the $20^{\text {th }}$ century and the consequent changes in relations between the two cultural circles. The work is focused not only on a comparative analysis of the text and music material from Parisian and Polish cabarets, but also takes into account the sociological context of their functioning. This allows the reader to understand similarities and differences in the creation and development of cabaret life in France and Poland. The article analyzes in detail a unique method used to disseminate songs in France (by the societies of singers called les goguettes, les cafés chantants, les cafés-concerts and cabarets) and the absence of such the phenomenon in Poland. It is shown that these cultural incompatibilities may be one of reasons for the gradual movement of Polish authors and artists away from the conventional and aesthetic style, adopted initially from the Parisian cabarets that were perceived as model ones in Europe (eg. Le Chat Noir or Le Mirliton).

\section{KEYWORDS}

history of the nineteenth- and twentieth-century theatre; nineteenth-century Paris; fin de siècle; cabaret; modernism; literature of the nineteenth century; song 

Prace Polonistyczne, seria LXXII, 2017

ISSN: 0079-4791; e-ISSN: 2450-9353

DOI: $10.26485 / \mathrm{PP} / 2017 / 72 / 11$

Cécile Bocianowski

\section{MISE EN CORPS DES « GUEULES » DE « FERDYDURKE » : LE BALLET GROTESQUE D'ANNA HOP À LA LUMIĖRE DE L'CEUVRE DE GOMBROWICZ}

\section{SŁOWA KLUCZOWE}

taniec; balet; groteska; Witold Gombrowicz; Ferdydurke; ciało; pantomima

Les œuvres de Witold Gombrowicz constituent une source d'inspiration pour nombre d'artistes polonais et étrangers qui produisent films, opéras, happenings, ballets, pantomimes, spectacles de marionnettes, opérette électronique ou autres productions destinées à un public adulte comme aux plus jeunes. Une grande partie de ces œuvres pour la scène se base sur les pièces de théâtre de l'auteur polonais en les mettant en scène telles quelles, en les adaptant ou encore en s'en inspirant librement. D'autres, de plus en plus nombreuses ces quarante dernières années, ne s'appuient non pas sur l'œuvre dramatique, mais sur la prose de Gombrowicz. Ces spectacles sont pour la plupart construits autour d'un choix de thèmes et de motifs tirés de ses œuvres, et combinent souvent dans leur création les textes gombrowicziens à d'autres textes, qu'il s'agisse de prose ou de textes dramatiques. Pour créer La Classe Morte (Umarta klasa) en 1975, Tadeusz Kantor puise son inspiration à la fois dans Ferdydurke, dans des nouvelles telles que Le Retraité (Emeryt) et Le Traité des mannequins (Traktat o Manekinach) de Bruno Schulz, mais aussi dans la pièce Tumeur Cervykal (Tumor Mózgowicz) de Stanisław I. Witkiewicz. Pour son récent spectacle au Théâtre Wilam Horzyca à Toruń (2014), Mikołaj Grabowski s'est quant à lui inspiré à la fois des Journaux, de Ferdydurke, du Mariage (Ślub) et de L'Histoire - Opérette (Operetka) de Gombrowicz, de la pièce Wyzwolenie

Cécile Bocianowski — dr, Faculté de Lettres, Traduction et Communication, Université Libre de Bruxelles, Avenue F.D. Roosevelt 50, 1050 Bruxelles (Belgique); e-mail: cecile.bocianowski@ulb.ac.be 
(Libération) de Stanisław Wyspiański et de l'ouvrage d'enseignement dramatique Mimika (La Mimique) de Wojciech Bogusławski.

On note un certain engouement du monde de la scène pour les textes non dramatiques de Gombrowicz, phénomène qui témoigne d'une double distanciation vis-à-vis de la forme proprement théâtrale : d'une part, les productions théâtrales se détournent des textes dramatiques pour leur préférer des textes narratifs ou intimes, et d'autre part, cet intérêt donne naissance à une expression dénuée de paroles, des œuvres chorégraphiques où le corps prend la place du mot. Double éloignement, donc, où le lien direct entre écriture dramatique et théâtre est délaissé au profit d'une exploration plus libre de l'œuvre en prose ; où le mouvement est préféré aux mots. Pour le chorégraphe et danseur Leszek Bzdyl, qui a monté deux spectacles inspirés de Gombrowicz, il n'est pas de meilleur auteur pour le théâtre du mouvement, de la danse et de la pantomime. (Oczak-Stach 2016). Nous verrons que cette affirmation est particulièrement vérifiée avec l'œuvre qui nous intéresse.

Parmi les adaptations polonaises de Ferdydurke figurent de nombreuses adaptations pour le théâtre, mais aussi plus récemment pour le théâtre radiophonique, le théâtre de marionnettes, ainsi que pour la danse contemporaine. Parmi ces derniers types d'adaptation pour des arts que d'aucuns pourraient qualifier de "mineurs ", citons le spectacle pour acteurs et marionnettes Ferdydurke de Radosław Kasiukiewicz au Théâtre de Marionnettes de Wrocław en 2013, le spectacle de danse/ballet Gombka F. destiné aux plus de 12 ans de Krzysztof Lubka à la Philharmonie de Szczecin en 2014, ou encore le ballet contemporain Pupa d'Anna Hop du Ballet National Polonais, présenté à l'Opéra National en 2015 et que nous examinerons ici.

Si la présence de l'œuvre de Gombrowicz au théâtre ou à l'opéra a déjà fait l'objet d'études, dans les arts chorégraphiques ce sujet reste un territoire encore peu exploré. Cet article propose d'examiner non pas la façon dont le ballet « illustrerait " ou mettrait en scène le texte de Gombrowicz, mais, une fois révélés les points de convergence entre écriture du corps et écriture littéraire, de voir quel éclairage la danse apporte au texte pour tenter de saisir la spécificité chorégraphique du regard sur l'œuvre de Gombrowicz, et dans un mouvement inverse, le rôle de la danse dans l'écriture gombrowiczienne.

\section{Un ballet ferdydurkien}

Pupa (Cucul) est un ballet en un acte, fruit de la collaboration de la chorégraphe Anna Hop avec le compositeur Stanisław Syrewicz, la scénographe Małgorzata Szabłowska (auteur également des projections), Katarzyna Rott, créatrice des 
costumes, et Maciej Igielski, auteur des lumières. La chorégraphie est basée sur le livret créé par Klara Syrewicz. La musique, qui a constitué le fondement de la création, avait en partie été composée pour le film 30 Door Key (Ferdydurke) de Jerzy Skolimowski en 1991, et a en partie été créée spécialement pour le spectacle. La danseuse et jeune chorégraphe Anna Hop a été choisie par le directeur $\mathrm{du}$ Ballet National pour mettre en corps et mouvements les compositions de Syrewicz. Connue pour ses ateliers chorégraphiques Kreacje (Créations) caractérisés par l'ironie, l'humour et l'absurde, Anna Hop est l'auteur des mouvements scéniques du spectacle Zrób sobie raj (Chacun son paradis), spectacle inspiré du recueil de reportages littéraires éponymes de Mariusz Szczygieł, mis en scène par Olga Chajdas et Kasia Adamik en 2012. C'est ainsi une jeune chorégraphe au travail marqué par l'ironie et par l'humour qui s'est attelée à la mise en corps et en mouvements du texte écrit par le jeune Gombrowicz.

Le ballet se compose de huit tableaux aux titres faisant référence à des thèmes et motifs centraux dans Ferdydurke, mais aussi dans d'autres ouvrages de l'auteur : Forme ; Démembrement ; Nudité ; Cuisse ; Maturité ; Słowacki ; Patrie ; Moi. La forme, problématique centrale du texte de Gombrowicz, est abordée dans le genre même choisi pour le spectacle, et subit un traitement similaire à celui qu'elle connaît dans le roman de Gombrowicz. Le ballet, forme chorégraphique définie, est souvent perçu comme schématique et rigide. À l'instar de Gombrowicz dans Ferdydurke, Anna Hop fait éclater la forme du ballet, en adoptant une esthétique grotesque pour composer sa chorégraphie.

La subversion de la forme du ballet est manifeste dans la parodie à l'œuvre dans "Maturité ». Le cinquième tableau s'ouvre sur l'entrée de danseurs emplis d'aisance, de prestance et de légèreté tels des danseurs de ballet classique qui, torse bombé, un bras sur la hanche et l'autre tendu, pointe en avant, se placent au centre de la scène et entament, sur le rythme des premières notes de violons, des sauts et pirouettes classiques. L'entrée de ces interprètes contraste avec la gestuelle à l'œuvre dans les quatre tableaux précédents, où le corps des danseurs est soumis à l'emprise de la forme, du démembrement et de la cuisse, autrement dit où le mouvement, loin de suivre le style classique du ballet, place d'emblée le spectateur face à un anti-ballet. Cette séquence classique au centre du plateau alterne avec les entrées et passages de couples de danseurs dans lesquels la danseuse, soutenue par le danseur, évolue sur la pointe d'une seule jambe à laquelle sont fixées des roulettes clignotantes. Les danseuses, soutenues par un ou deux danseurs qui les font rouler sur le plateau, dessinent des cercles, courbes et arabesques. Elles entrent et sortent de scène, tournent sur leurs roulettes clignotantes telles des figurines mobiles ou des poupées. Ce ballet dans le ballet use de la caricature et de l'humour, notamment lorsqu'un danseur soutenant la jambe arrière tendue 
d'une danseuse joue à l'abaisser comiquement sur le rythme de deux notes aigües répétées. La forme du ballet est ainsi fissurée par le burlesque ; le ballet classique est pour ainsi dire "ferdydurkisé ", dans le sens où, tel Gombrowicz se jouant des conventions du roman, Anna Hop se joue des conventions du ballet pour livrer un spectacle grotesque dans sa forme même. Pour le compositeur Stanisław Syrewicz, le "ferdydurkisme " du ballet réside non seulement dans sa forme, mais également dans son académisme : "le ballet, en tant qu'institution, est très „ferdydurkien”. C'est une école où l'on forme l'homme, il y a des professeurs Pimko : tout cela était évident pour moi. » (Syrewicz 2016: 12).

Outre sa forme subversive, Pupa emprunte à Ferdydurke une série de ses thèmes centraux, comme le souligne Klara l'auteur du livret :

La construction de ce spectacle, plutôt que de suivre la narration de Ferdydurke, est une réponse à des motifs évoqués dans le roman, comme l'impossibilité de s'exprimer, la platitude des traditions culturelles, l'oppression ou la solitude. [...] à chaque instant, l'individu ou le groupe est confronté à "l'enfer de la forme " gombrowiczien : la discipline scolaire, le rapport ankylosé à la culture et la patrie, l'accomplissement du rôle qui nous est attribué au sein de la famille, l'adaptation aux canons de beauté en vigueur, le conformisme des relations romantiques, etc. Les divers tableaux du spectacle révèlent l'impossibilité de s'extirper du corset de la personnalité qui nous est imposée. (Warszawa 2015)

D'un côté, les huit tableaux décrits par le livret rattachent le ballet à l'usage traditionnel du littéraire dans l'histoire du ballet. Si l'œuvre ne suit pas la structure narrative - ou plutôt antinarrative — de Ferdydurke mais répond à une construction thématique, elle inscrit toutefois l'œuvre dans un traitement du littéraire traditionnel qui entretient un rapport de proximité avec le texte de Gombrowicz en organisant la chorégraphie selon les thèmes du roman. D'un autre côté cependant, la rencontre entre danse et littérature dans Pupa va au-delà du simple mimétisme et s'inscrit dans l'usage moderne du littéraire en danse, qui déplace

le curseur de l'intérêt chorégraphique pour l'art littéraire bien au-delà de la béquille narrative, à l'endroit d'un échange possible de "paysages intérieurs ", de sensations poétiques, implicites, invisibles mais fondamentales, capables de mettre le corps en mouvement. (Godfroy 2015: 24)

Avant de procéder à l'analyse des interactions entre les espaces intérieurs des créateurs de Pupa et de ceux de Gombrowicz, il convient de déterminer la nature d'un autre type d'interaction entre texte et danse, plus concret, à savoir la présence ou l'absence littérale du texte dans l'œuvre chorégraphique. Lucille 
Toth distingue trois catégories de mise en corps et mise en voix du texte sur la scène contemporaine, trois types de "délivrance du littéraire en danse " (Toth 2015: 18) qu'elle détermine en fonction de l'énonciateur du texte : danseur parlant, danseur $v$ s récitant et absence de texte. Pupa s'inscrit dans le troisième type, dans la mesure où il n'est ni danseur, ni acteur qui déclamerait le texte même de Gombrowicz sur scène.

Cependant, le ballet recèle un autre type de présence du texte qui se manifeste à travers la voix de Gombrowicz lui-même, les créateurs du spectacle ayant pu bénéficier de l'accord de Radio Free Europe pour l'utilisation de l'enregistrement de la voix de l'auteur dans le spectacle. Ainsi, le spectateur entend de la bouche de l'auteur polonais deux fragments tirés de son Journal : «Poniedziatek Ja. Wtorek Ja. Środa Ja. Czwartek Ja » (Gombrowicz 2007: 9) ainsi que « Nie można przez cały tydzień być nicością, aby w niedzielę zaistnieć ». (Gombrowicz 2007: 59) La voix et le texte de l'auteur sont insérés dans la dernière partie du ballet, intitulée " Moi ». Un portrait de Gombrowicz est projeté à ce moment-là sur le mur en arrière-plan, un dessin aux couleurs patinées, à l'image brouillée et déformée. Et lorsque le texte est déclamé, toute sa mâchoire inférieure se détache de façon à mimer l'ouverture de la bouche, comme chez ce qu'on appelle les " marionnettes à gueule ", mimant ainsi l'acte de parler.

On distinguera, à ce stade de l'analyse, des interactions de nature différente entre le ballet Pupa et le texte de Gombrowicz. Tout d'abord, le spectateur se trouve face à une certaine quantité de signes qu'il associe directement au texte. Le paratexte que forment les titres et le résumé des divers tableaux du ballet dans le programme constitue le premier de ces signes dans la réception du spectateur. À cela s'ajoute la déclamation à la lettre du texte du Journal dans le tableau final, mais aussi des insertions pantomimiques de scènes empruntant à certains passages narratifs du roman. Ainsi, le tableau "Słowacki » met clairement en scène des élèves et leur maître, ainsi que le rapport de domination qui renvoie au premier épisode de "cuculisation" subi par le narrateur dans le roman. Face aux références directes ou échos intertextuels, le spectateur fait appel à sa mémoire de lecteur. Ce mécanisme est d'autant plus présent dans la réception du ballet que l'œuvre de Gombrowicz constitue désormais un classique de la littérature polonaise.

Mais le ballet d'Anna Hop ne se résume pas à une gestuelle concrète destinée à être associée au texte de Gombrowicz. En effet, la chorégraphe s'est attachée à livrer une réécriture corporelle du texte, soutenue par des accessoires, une scénographie et une musique qui en font une création par moments dissociée du texte. Anna Hop a ainsi fait le choix d'une œuvre marquée par le présent, notamment pour rendre l'idée gombrowiczienne du « moi » à l'aune de la contemporanéité. 
"La technologie moderne a créé de nombreuses possibilités de manipulation de l'identité ", comme le souligne le compositeur. (Syrewicz 2016: 12) Ce choix se manifeste le plus concrètement par l'usage d'accessoires technologiques issus du quotidien, notamment dans le tableau intitulé "Cuisse ", où sont exploités des tapis de course évoquant le culte de la performance, du corps et de l'image, et surtout dans la partie intitulée " Moi » où des smartphones, tablettes et selfie sticks sont employés comme accessoires. Insérés dans le ballet de façon ingénieuse, ces appareils ont à la fois pour rôle d'éclairer le visage des danseurs d'une lumière bleue - ou plutôt le masque qui recouvre leur visage, à mi-chemin entre le masque d'escrimeur et celui d'apiculteur — et renvoient à l'image du miroir dans lequel les danseurs pourraient contempler leur image. Leurs mouvements sur scène sont guidés par l'appareil qu'ils tiennent devant eux. Avançant en cadence, au rythme de la musique et des "Lundi. Moi. Mardi. Moi. " prononcés par la voix de Gombrowicz, les danseurs invitent les spectateurs à envisager la pensée de l'auteur d'une perspective différente, actuelle, qui prenne en compte la problématique du " moi » et de la forme dans un monde ultraconnecté, où la forme ne concerne plus seulement les contacts interhumains, mais aussi la présence et les interactions sociales sur Internet.

Ainsi, même s'il est matériellement absent sur scène, le texte demeure " le moteur " de la chorégraphie. Lucille Toth, dans son analyse des spectacles de Tatiana Julien et Maguy Marin, souligne le rôle de moteur du texte, qui opère grâce à la présence fantomatique du texte dans le lecteur-spectateur. Selon Toth, les chorégraphes Julien et Marin

s'adressent toutes les deux à un spectateur érudit hanté par une lecture devenue spectrale. L'absence physique, matérielle de l'écrit — « hantologie " derridienne s'il en est - n'enlève en rien l'aura du littéraire qui envahit la danse. Le texte ne manque pas à la danse, il en est le moteur et s'insinue dans l'œil du regardeur. (Toth 2015: 21)

Pupa puise ainsi tant dans une logique intertextuelle que dans celle d'une réécriture où « la trace littéraire est digérée par la chorégraphe et régurgitée par les mouvements de son corps, qui devient le palimpseste de cette écriture " (Toth 2015: 21). C'est là que réside la perspective la plus intéressante dans l'étude des interactions entre danse et littérature, entre

d'un côté, l'art littéraire, art du geste de la trace qui passe par la médiatisation du langage verbal et s'inscrit dans un objet survivant détaché du corps; de l'autre, l'art chorégraphique, art du geste sans trace qui s'est retiré en bloc de l'univers du verbal pour déployer, sans autre médium que le corps, un langage en deçà de la signification. (Godfroy 2015: 23) 
Le texte, physiquement incarné par le danseur, voit son sens " régénéré par le corps, par la voie des sens " (Godfroy 2015: 27), et la prose gombrowiczienne, hantée par le corps et le geste, se prête particulièrement à cette réécriture corporelle.

\section{La mise en corps, ou la mise en pièces du corps}

Le corps et la corporéité sont omniprésents dans l'œuvre de Gombrowicz. Expression matérielle de la forme avec le geste, le corps est au cœur de l'attention du narrateur qui non seulement lui accorde une place prépondérante dans la narration, mais appréhende le monde en termes de corporéité. La gueule et le cucul, symboles de l'infantilisation et de l'imposition d'une forme par les autres, prennent une telle importance dans le roman, à la fois sur le plan narratif que sémantique, qu'ils fonctionnent, comme l'a souligné Hélène Włodarczyk, comme des métasignes créés par leur répétition au fil du roman. "C'est par la répétition, par la répétition qu'on crée le plus facilement n'importe quelle mythologie! " écrit Gombrowicz dans Ferdydurke. (Gombrowicz 1995a: 104) Les mollets, symboles de la modernité, atteignent le statut de langage pour le narrateur, ils expriment à eux seuls la forme moderne que s'attachent à afficher Zuta et sa mère :

Après avoir bien réfléchi, j’ai réussi à traduire en langue intelligible la strophe que voici :

\section{LE POÈME}

Les horizons éclatent comme des bouteilles

Une tache verte gonfle sous les nuages

Je reviens à l'ombre des pins -

d'où

j'aspire d'une bouche avide

mon Printemps quotidien.

MA TRADUCTION

Mollets, mollets, mollets, mollets,

Mollets, mollets, mollets, mollets,

Mollets, mollets, mollets -

mollet,

mollet, mollet, mollet,

mollets, mollets, mollets. (Gombrowicz 2015: 230)

Soulignons que le corps se substitue aux mots non seulement sur la scène du ballet Pupa, mais déjà dans l'œuvre même de l'auteur. Gombrowicz se sert 
du corps pour l'appréhension du monde et de ses formes, mais aussi pour celle de l'écriture et de la lecture. Dans Introduction à "Philidor doublé d'enfant ", le narrateur justifie la présence de cette partie par le lien entre paroles et parties du corps, et présente la construction de son roman comme un corps dont le cucul serait le fondement et certaines parties du corps des ramifications, parties qui subissent " des métaphores subtiles et artificieuses ». (Gombrowicz 1995a: 102-103) Quant à la partie Philidor, c'est " un boyau, un boyau sans lequel je ne pourrais jamais passer au mollet gauche ", nous dit Gombrowicz. (Gombrowicz 1995a: 103) Ces considérations sur les parties de son texte se développent à cet endroit du roman pour s'étendre à la lecture qui est inévitablement partielle, puisque le lecteur n'absorbe la totalité de l'œuvre que parcelle par parcelle, interrompu qu'il peut être par une sonnerie de téléphone ou une mouche. (Gombrowicz 1995a: 105) Et c'est à une philosophie des parties que le corps conduit le narrateur :

Voilà donc les raisons essentielles et philosophiques qui m'ont conduit à construire cet ouvrage sur la base de parties séparées, en concevant l'œuvre comme une partie d'œuvre, l'homme comme un groupement de parties, l'humanité comme un mélange de parties et de morceaux. (Gombrowicz 1995a: 109)

Car c'est bien plus de parties du corps que de corps en soi qu'il est question dans le roman, où cette philosophie des parties séparées et autonomes imprègne la réalité au point de rendre matérielle la manipulation de la forme, de donner littéralement corps à la pensée. Dans Philidor doublé d'enfant, l'Anti-Philidor décompose les corps à coups d'énumérations. (Gombrowicz 1995a: 130) Par exemple, lorsqu'il prononce "L'oreille ! L'oreille ! » à l'attention de l'épouse de Philidor, "sous l'influence de ces paroles, l'oreille se dévoile de façon inconvenante. " (Gombrowicz 1995a: 132)

Si le duel de paroles des deux savants illustre la matérialisation des mots par le corps, l'épisode de la danse du narrateur est un exemple on ne peut plus intéressant pour notre analyse :

Mais c'est seulement quand je me fus mis à danser tout seul moi aussi que mes pensées prirent corps et se transformèrent en acte, ridiculisant tout à la ronde, et en extrayant le mauvais goût. Je dansais, et cette danse sans partenaire dans le silence et la solitude se chargeait d'une folie qui m'effrayait. Quand j'eus dansé devant les essuie-mains des Lejeune, leurs pyjamas, leur pâte à raser, leurs lits et leurs autres ustensiles, je me retirai en vitesse et fermai la porte derrière moi. Je l'avais bien arrangé avec ma danse, leur intérieur moderne! Et maintenant, maintenant, à la chambre de la lycéenne, pour la danser et la gâcher aussi ! (Gombrowicz 1995a: 222) 
Dans cette scène, le corps et, à travers lui, la danse matérialisent non seulement la pensée du narrateur, mais réalisent l'acte de vengeance destiné à déstabiliser les Lejeune et leur forme si parfaitement moderne. Solitaire, silencieuse, destinée à enlaidir et ridiculiser les Lejeune à travers les objets de leur intimité, effrayante, frisant la folie (le texte polonais parle de danse sautillante, "pląs ") et révélant le mauvais goût, c'est bien une danse grotesque à laquelle se livre le narrateur. Une danse détournée de ses intentions et significations usuelles, que l'emploi inusuel du verbe "danser » dans la traduction française - création du traducteur - illustre de façon idéale : le narrateur danse la chambre.

Anna Hop a construit son ballet sur les parties du corps qu'elle a su mettre en valeur tant par le choix des costumes que par la chorégraphie, la scénographie, la projection vidéo et les lumières. Tout d'abord, les costumes collants dont sont enveloppés les danseurs des pieds à la tête révèlent, par un jeu d'ombres marqués par la couleur ocre-rouille, la forme des muscles et des parties du corps. Les formes des mollets, des fessiers, des bras, des jambes, etc. sont ainsi mises en exergue.

Dans la partie intitulée " Nudité », la vidéo-projection permet de mettre en scène un corps constitué d'une multitude de parties. Plongée dans le noir au début du tableau, l'arrière-scène s'anime de délicats groupes de points lumineux qui, au rythme de la danse, se multiplient jusqu’à passer, de conglomérats de points, à la forme d'une silhouette humaine. Les points lumineux recouvrent et illuminent un danseur allongé au sol. S'ensuit alors une séparation entre le corps du danseur et les points lumineux qui viennent former une silhouette humaine sur le mur $\mathrm{du}$ fond de la scène. Un duo débute entre le corps réel et le corps virtuel, celui-ci n'étant autre que l'être intérieur du danseur. La confrontation des deux êtres se traduit par des gestes d'abord mimétiques, la silhouette reproduisant les gestes du danseur, puis par une interaction non mimétique. La forme évanescente constituée d'une multitude de points se dilue puis se reforme, passant d'une forme à une autre, puis grandit, jusqu'à devenir un géant à l'échelle du danseur. Dans cette position de supériorité, la silhouette se penche et enferme le danseur dans ses mains pour ensuite le libérer. Le jeu entre la vidéo-projection et la danse constitue l'une des modalités que la chorégraphe a choisies pour l'expression du problème de la forme. Dans le tableau précédent, intitulé "Démembrement ", c'est cette fois au jeu des lumières sur les danseurs qu'a recours la chorégraphe pour mettre littéralement en corps et mouvements les parties du corps chères à Gombrowicz.

Dans ce tableau, le corps démembré évolue dans une scène à la fois humoristique et délicate où seules dansent des parties du corps : les interprètes, plongés dans l'obscurité, sont vêtus d'un costume collant entièrement noir à l'exception 
d'une partie du corps de couleur chair et aux muscles accentués. C'est ainsi que surgissent de l'obscurité, éclairés le temps d'une note de cuivres, une jambe côté cour, une main côté jardin. S'ensuivent les apparitions d'autres parties du corps exécutant des mouvements au rythme de la musique. Ces gestes et parties détachés du corps produisent un effet très réussi de mise en mouvement des parties du corps gombrowicziennes. Les gestes exécutés empruntent à ce qu'on appelle la gestualité " quotidienne " ou "familière ". (Febvre 1995: 37) Ainsi, au fur et à mesure, les pantomimes reproduisent acquiescements de la tête, mouvement du doigt invitant à s'approcher, mais aussi gratouillis au menton et coup de pied aux fesses. La mise en scène d'une jambe seule donnant un coup de pied au fessier met en corps ce que Gombrowicz décrit dans Ferdydurke lorsque Zuta donne un coup de pied dans le tibia du narrateur : "Le coup de pied qu'elle m'avait donné ne me facilitait pas la tâche car c'était un coup isolé, infligé par une jambe sans la participation du visage ». (Gombrowicz 1995a: 172) Les parties du corps mises en scène dans cette séquence reprennent par moments les mimiques et autres gestes enfantins, notamment quand des mains surgissant de derrière une tête en frottent les yeux avec les poings ou quand une tête tire la langue, ou encore par des gestes singeant et détournant des gestes du quotidien, comme un pied qui sert de combiné de téléphone à une tête qui approche l'oreille. Cette séquence laisse place à un tableau collectif où toutes les parties du corps, toujours éclairées individuellement, s'adonnent à un ballet en effectuant chacune un geste singulier, formant ainsi un tableau collectif de parties du corps dansantes, se transformant progressivement en un tas, un enchevêtrement de parties du corps qui finissent, dans un tourbillon, par écraser une tête. La vision obtenue rappelle la mêlée des Lejeune décrite par Gombrowicz dans le chapitre "Déchaînement de jambes et nouvel attrapage " ainsi que celle des élèves dans « Attrapage et suite du malaxage».

On pourrait distinguer, dans la réécriture corporelle de Ferdydurke, deux types de mouvements, qui s'appuient d'un côté sur la pantomime et de l'autre sur le geste "dé-sémantisé » de la danse contemporaine. (Godfroy 2015: 27) La corporéité du texte de Gombrowicz et le problème de la forme poussent naturellement le geste chorégraphique vers la pantomime qui est très présente dans le roman lui-même. La pantomime participe de la farce et du grotesque des scènes décrites par Gombrowicz. Sur scène, la chorégraphe l'exploite dans des séquences s'inspirant de scènes du roman, comme nous l'avons vu plus haut, ainsi que dans une réécriture des rapports de force présents dans le texte. Ainsi, dans la première partie du ballet intitulée " forme " apparaît un danseur au costume différent des autres, aux détails plus marqués, qui porte un masque. Son entrée sur scène est marquée par une allure menaçante qu'accompagne une musique dissonante et 
inquiétante. Au cours du premier tableau, cette domination se matérialise dans une scène où il manipule les autres danseurs, tel un marionnettiste : muni d'une sorte de harnais auquel sont fixés des fils rétractables, il accroche chacun de ces fils au corset dont est muni chaque danseur dans le premier tableau. Ceux-ci se retrouvent à la merci de leur manipulateur qui les empêche d'évoluer librement, les fait sautiller, les redresse, les fait tomber au sol. La chorégraphe emploie ici l'un des procédés de l'esthétique grotesque théâtrale du XX $\mathrm{X}^{\mathrm{e}}$ siècle, dans laquelle la marionnettisation des personnages joue un rôle important. (Bocianowski 2016: 237-256).

Les scènes de pantomimes, qu'elles soient une référence directe au texte de Gombrowicz ou non, alternent avec des séquences plus abstraites où le geste n'est pas chargé d'une signification que l'on peut directement associer au texte. Le ballet repose sur un enchevêtrement de ces deux types de gestualité, superposant le langage chorégraphique au langage littéraire, superposition qui, selon Lucille Toth,

oblige le spectateur à faire appel à sa mémoire de lecteur, à retrouver parfois de lui-même le littéraire dans le chorégraphique et, surtout, à sentir physiquement, à incorporer la lecture passée. [...] Plus encore qu'au cinéma (friand de littérature), le vis-à-vis avec le danseur créé une forme d'intimité singulière, puisque chaque spectacle est performé de manière unique et augmente la fragilité du spectateur qui se voit investi mentalement autant que physiquement. Car c'est en lui, en son corps et en son âme, que le sens se fera. Pour Jerzy Grotowski, le spectateur doit « se laisser investir par la « corporéité » de l'acteur. Par son regard, son haleine, sa sueur. " L'idée d'un même présent, un présent physique, s'éloigne de la posture du lecteur en sécurité face à l'objet-livre. La mise en corps du livre ne s'opère plus uniquement sur l'espace scénique, elle résonne également dans le corps du regardeur qui assimile et peut-être réconcilie par là même les deux écritures littéraire et chorégraphique. (Toth 2015: 21-22)

La rencontre entre danse et littérature s'accomplit plus que pour tout autre auteur, à travers et dans le corps, et n'investit ainsi pas seulement le corps du texte et celui des danseurs, mais aussi celui du spectateur, selon Lucille Toth. Ce qui l'amène à formuler l'idéal de la rencontre entre danse et littérature faisant de l'artiste et du regardeur "un même corps pensant dans une pensée en mouvement ». (Toth 2015: 22) Cette vision semble particulièrement pertinente dès lors que, comme nous l'avons dit plus haut, Gombrowicz avait fait le récit de sa pensée prenant corps dans la danse.

Poussons encore l'idée du corps danseur-auteur-spectateur à laquelle nous avons abouti pour revenir à l'écriture littéraire et l'examiner à l'aune de l'acte de danser. Et portons la question de l'émergence du geste non plus sur la création chorégraphique, mais sur la création littéraire, pour aboutir au « noyau commun 
à l'acte de danser et à l'acte d'énoncer ». (Godfroy 2015:28) Nous avons souligné le rôle important de la danse dans Ferdydurke : le narrateur danseur, dansant la chambre des Lejeune. Ne pourrait-on considérer non plus le narrateur, mais l'auteur de Ferdydurke comme un danseur virtuel et associer son acte d'écrire à celui de danser ? Alice Godfroy, dans le développement de sa théorie de la " dansité ", décèle, dans l'écriture littéraire :

Une microkinesis, une chorégraphie du dedans que l'écriture a en charge de convoyer sans pour autant la consigner, et qui s'imprime dans le mouvement des textes, leur procurant une certaine «dansité ». [...] Il ne s'agit pas de prétendre ici que l'écriture serait une chaire dédiée à la pure exposition des corps (elle ne le peut), mais de constater, dans ses entreprises les plus poétiques, et bien au-delà du genre appelé "poésie ", que ses couches sémantiques s'étayent sur un champ de sentis pré-verbaux fortement potentialisés, et tant condensés qu'ils transpirent par-delà le sens et nous touchent directement, empathiquement. (Godfroy 2015: 28-29)

C'est en remontant aux sources de l'expressivité, " quand l'articulation de la langue et celle du corps sont encore noués l'une à l'autre "(Godfroy 2015: 29), qu'Alice Godfroy élabore l'idée de la "dansité » de l'écriture. Cette idée ouvre une perspective intéressante quant à l'écriture de Ferdydurke : puisque l'auteur pense la construction de son œuvre en termes de corps, qu'il associe volontiers à la musique, comme lorsqu'il emploie la métaphore de la coda ou du trille pour parler d'une partie de son roman, il ne reste qu'un pas à franchir vers l'idée de l'écriture en tant que danse, une mise en mouvement de toutes ces parties du corps - boyaux, mollets, doigts, dents, talons qui constituent les parties de l'œuvre. Et celle de Gombrowicz danseur. Danseur d'une danse hybride, répétitive, déformée, déconcertante, comique — une danse grotesque.

\section{BIBLIOGRAFIA:}

Bocianowski Cécile. 2016. La marionnettisation des personnages dans le théâtre francophone et polonais du vingtième siècle. „Prace Polonistyczne” 2016, nr 71. S. 237-256.

Febvre Michèle. 1995. Danse contemporaine et théatralité. Paryż: Chiron.

Godfroy Alice. 2015. Pourquoi la littérature mobilise-t-elle le corps dansant? W: Danse contemporaine et littérature, entre fictions et performances écrites. Red. Magali Nachtergael i Lucille Toth. Pantin: Centre National de la Danse. S. 23-30.

Gmys Marcin. 2004. Gombrowicz w rytmie danse macabre. O operowych adaptacjach Iwony, księżniczki Burgunda oraz Ślubu. „Pamiętnik teatralny” 2004, nr 1-4 (209-212). S. 102-117.

Gombrowicz Witold. 1995a. Ferdydurke. Tłum. Georges Sédir. Paryż: Gallimard. 
Gombrowicz Witold. 1995b. Journal 1953-1958. Tłum. Allan Kosko. Paryż: Gallimard.

Gombrowicz Witold. 2007. Dziennik 1953-1958. Kraków: Wydawnictwo Literackie.

Gombrowicz Witold. 2010. Ferdydurke. Warszawa: Wydawnictwo Literackie.

Kuharski Allen J. 2007. Improvisation à partir d'un cadavre. W: Witold Gombrowicz: entre l'Europe et l'Amérique. Red. Marek Tomaszewski. Villeneuve d'Ascq: Presses Universitaires du Septentrion. S. 29-49.

Oczak-Stach Dorota. 2016. „Pustka. Pustynia. Nic.” Gombrowicz we Wroctawskim Teatrze Pantomimy. „Gazeta Wyborcza - Wrocław” z dnia 8.03.2016 r.

Syrewicz Stanisław. 2016. Gombrowicz rozpisany na partyturę, rozmowa z Maciejem Ulewiczem. W: Program baletu Pupa. Warszawa: Teatr Wielki - Opera Narodowa.

Toth Lucille. 2015. Mise en corps, mise en voix : le texte et ses apparitions sur la scène chorégraphique contemporaine. W: Danse contemporaine et littérature, entre fictions et performances écrites. Red. Magali Nachtergael i Lucille Toth. Pantin: Centre National de la Danse. S. 17-22.

Van Buuren Maarten. 1982. Witold Gombrowicz et le grotesque. „Littérature” [online]. Protokół dostępu: http://www.persee.fr/doc/litt_0047-4800_1982_num_48_4_2177 [10.11.2016].

Warszawa: Polski Balet Narodowy - wkrótce premiera: „Pupa” w choreografii Anny Hop, [online]. Protokół dostępu: http://www.taniecpolska.pl/aktualnosci/show/3351 [10.11.2016].

Włodarczyk Hélène. 2003. Gombrowicz et les signes ou la sémiotique comme méthode littéraire. „Revue de littérature comparée” 2003/3, nr 307. S. 293-303.

Cécile Bocianowski

\section{THE GROTESQUE BALLET OF ANNA HOP IN LIGHT OF GOMBROWICZ'S WORKS}

(summary)

This article examines Anna Hop's 2015 ballet, based upon Witold Gombrowicz's novel Ferdydurke, created at the National Polish Ballet, analysing the interaction between the choreography and literary language to demonstrate the choreographic specificity of Hop's treatment of Gombrowicz's text.

KEYWORDS

dance; ballet; grotesque; Witold Gombrowicz; Ferdydurke; body; pantomime 

NA MARGINESACH LEKTUR 

Prace Polonistyczne, seria LXXII, 2017

PL ISSN: 0079-4791; e-ISSN: 2450-9353

DOI: $10.26485 / \mathrm{PP} / 2017 / 72 / 12$

Piotr Bitos

\section{TADEUSZ BOY-ŻELEŃSKI : UNE CRITIQUE LITTÉRAIRE ENGAGÉE DANS L'EXPLORATION DE LA VIE ET DE L'AUTONOMIE DE L'ART}

\section{SŁOWA KLUCZOWE}

Żeleński Tadeusz (Boy); krytyka literacka; krytyka immanentna; oralność

\section{L'oralité}

Malgré leur aspect quelque peu unilatéral, les analyses de Walter Jackson Ong ${ }^{1}$ sur la différence entre l'oralité et l'écrit, qui scrutent les répercussions de celle-ci sur les maillons successifs de la chaîne communicationnelle, restent précieuses. J'en rappelle ici quelques traits essentiels. Le passage de l'oral à l'écrit entraîne la transformation du signifiant sonore originel en signe visuel. Ainsi, une expérience, à l'origine auditive et physique, devient spatiale. Avec le passage à l'écrit, nous avons réifié le signe visuellement. C'est en tant que signe visuel que le signe écrit, puis imprimé, est décodé ; ce n’est que dans un second temps qu'il peut être éventuellement rendu à sa dimension sonore au moyen de l'imagination.

L'écrit procède ainsi d'une métamorphose technologique de l'oral. Celle-ci se marque en particulier par la coupure et la distanciation entre l'interprète, son

Piotr Biłos - dr hab. prof. INALCO, Institut National des Langues et Civilisations Orientales, 65 Rue de Grands Moulins, 75013 Paris, France; e-mail: piotr_bilos@hotmail.fr

1 À l'époque où je rédigeais ce texte, les textes de Ong n'étaient pas encore disponibles en français. J'ai donc retraduit à partir de deux recueils d'articles et d'essais eux-mêmes traduits vers le polonais. Voir bibliographie à la fin de l'article. 
texte et l'auditoire, chose que la performance orale, ancrée simultanément dans ces trois instances, ne connaît pas. Or, la littérature, c'est-à-dire les textes écrits dotés du statut d'œuvre d'art, possèdent une préhistoire orale dont le mode de fonctionnement ne coïncide pas avec celui de l'écrit. La performance orale, quant à elle, suppose une interaction vivante entre l'orateur et son auditoire; elle appelle nécessairement une double participation (l'orateur est perméable aux réactions du public et le public réagit en effet directement au récit). Ce que dit l'orateur se règle d'une manière ou d'une autre sur les réactions et l'attitude de l'auditoire.

Le discours oral est compris comme s'intégrant pleinement à la vie réelle où les hommes, les femmes et les enfants vivent, mangent et grandissent en discutant de questions existentielles et en prenant des décisions pratiques. Avec l'apparition de l'écriture et de l'imprimerie la question de savoir qui parle, à qui il s'adresse et ce qu'il dit devient beaucoup plus complexe et souvent ambiguë. Personne ne se parle à soi-même trop longtemps et s'adresser à un absent comme s'il était présent ne va pas de soi, or telle est précisément la situation dans laquelle se retrouve tout scripteur : en feignant de s'adresser à quelqu'un qui n'est pas là, il tient pour soimême un discours dont la longueur atteint à des proportions impressionnantes. Mais il y a plus. Ce que l'auteur écrit, va vivre indépendamment de lui, et peu importe, à partir de là, s'il est présent physiquement, voire mort. La plupart des textes que nous lisons ont été écrits par des gens qui ne sont plus vivants, certains depuis des siècles. Toute forme écrite constitue ainsi un tombeau et une épitaphe, empreinte de celui qui l'a créée. Cette absence de l'auteur au sein d'un texte qu'il a pourtant produit lui-même fait que l'écrit par opposition à l'oral repose sur une certaine coupure, une distance, un écart entre l'auteur, le texte et le public. Le texte écrit tend, par une pente naturelle, à être considéré comme un objet autonome, séparé aussi bien de son amont que de son aval :

L'imprimerie a poussé à sa plus extrême limite la transformation de la sonorité éphémère des mots en espace visible quasi-ineffaçable. (Ong 2009: 96)

Au départ, certes, le texte écrit n'était encore que la transposition à l'écrit d'un discours conçu sur un mode plus ou moins oral : l'auteur s'y adressait à des auditeurs imaginaires dans le cadre d'un discours qui se voulait encore oral bien qu'il fût transposé à l'écrit. Ce n'est qu'ensuite qu'apparaissent les véritables écrivains, hommes de lettres, lesquels sont fondamentalement des scripteurs, eux qui ne conçoivent la production de leurs textes qu'à l'écrit et qu'au moyen de l'écriture. Le contact ne se produit plus avec un auditoire mais avec du papier, plus tard, sur une feuille tapée à la machine, aujourd'hui, un écran d'ordinateur. Même si l'écrit continue d'intégrer des résidus d'oralité originelle, il répond à des questions nouvelles et incarne un nouveau modèle de conception verbale. 
La psyché humaine, qui a intégré le modèle de l'écrit renforcé par l'impression, subit donc une profonde transformation.

Car les conditions qui président à la production d'un texte écrit et d'un discours oral diffèrent assez sensiblement. Le mot écrit est isolé du contexte à l'intérieur duquel prend naissance le mot parlé, il se détache de la situation existentielle réelle tandis que les mots parlés, jamais, n'apparaissent tout seuls, c'est-à-dire dans un contexte qui ne serait fait que de mots. On peut dire qu'il ne fait pas bon aux mots parlés d'être tous seuls :

De plus, au cours d'une lecture silencieuse, devenue la norme, mais jadis exceptionnelle, le lecteur lui aussi se trouve isolé, solitaire. L'absence parle à l'absence. (Ong 2009: 133-134)

Très souvent l'auteur avec lequel le lecteur entre en communication est un auteur mort. Le discours oral, lui, provient nécessairement d'une personne vivante.

\section{Entre biographisme et poétique immanente de l'ouvre}

Indéniablement, Tadeusz Boy-Zelenski est d'abord et avant tout un polyscripteur. Dans le bloc des écrits qui relèvent des études littéraires, se profilent au moins trois sous-genres. Leur objet, bien qu'il se range dans la catégorie générale du fait littéraire, change assez radicalement de nature. Ainsi, les esquisses philologiques et critiques concernent avant tout la littérature française (Boy les adjoignait à titre de préface à ses traductions). La plupart de ces auteurs étaient morts et Boy ne pouvait donc pas les connaitre. Les études sur des auteurs polonais tels que Mickiewicz ou l'auteur de comédies, le comte Aleksander Fredro, entendent quant à elles déconstruire la tendance à l'élévation mystico-patriotique à laquelle une certaine histoire littéraire polonaise sacrifiait alors : le ton du critique devient ici polémique. Quant aux "feuilletons littéraires ", ils se rapportent, pour la plupart, à un milieu (La bohème littéraire), un lieu (Cracovie) et un courant littéraire (la Jeune Pologne) dont Boy fit l'expérience durant sa jeunesse. L'une des figures de proue de ce courant, Stanisław Przybyszewski, comme il le rapporte lui-même, écrivit que c'était bien Boy qui avait vocation à écrire cette histoire ${ }^{2}$.

C'est surtout ce Boy-là que je me propose d'explorer aujourd'hui (auquel on aurait pu adjoindre le critique de théâtre). Un Boy qui est à la fois historien de la littérature, critique et chroniqueur-témoin et - last but not least - écrivain-critique.

2 Les citations des feuilletons de Boy proviennent essentiellement du volume Reflektorem $w$ mrok ["Aves des phares dans les ténèbres »]. Je traduis toutes les citations. 
Ici ou là on continue à entendre dire que ce type de critique littéraire est aujourd'hui anachronique. L'argument ? Boy pratique le biographisme, à l'instar d'un Sainte-Beuve ou d'un Hyppolite Taine, il ferait dépendre l'œuvre de facteurs qui lui préexistent et gravitent autour d'elle. Dans cette approche, c'est l'homme qui est censé expliquer l'œuvre, et il faudra attendre le structuralisme pour que celle-ci se voie conférer une légitime autonomie.

Rappelons que Sainte-Beuve, en effet, s'éloigne radicalement de la poétique immanente de l'œuvre. Un peu par tempérament, un peu parce que son système de pensée l'y poussait, le pape de la critique littéraire française d'alors considérait le texte comme très largement tributaire de la situation existentielle et sociale entourant sa venue au monde. Pour lui, un texte, de tous côtés, subit la pression de la vie.

«La littérature n'est pas pour moi distincte ou, du moins, séparable du reste de l'homme et de l'organisation. " (Marcel Proust 1987: 126) "Un homme, écrivait-il, c'est-à-dire autre chose qu'un pur esprit. » (Marcel Proust 1987: 126) Dans cette conception, l'écrivain ne vit pas enfermé dans une tour d'ivoire, et sans cesse lui parviennent les échos de la vie sociale tandis que son individualité particulière imprègne directement le moindre atome du texte qu'il est en train de concevoir.

À chaque fois, il faut se poser " un certain nombre de questions " sur l'auteur et son époque, "quand même ces questions sembleraient les plus étrangères à la nature de ses écrits. " (Marcel Proust 1987: 126) Sur le rapport que l'écrivain entretient à des phénomènes tels que la religion, la nature, les femmes, l'argent, son statut matériel, social, son comportement moral, son emploi du temps quotidien etc.

La méthode beuvienne, c'est le reproche qu'on lui adressera, Proust en tête, aboutit à réduire comme une peau de chagrin la part proprement littéraire de l'œuvre, sa poétique propre, et grossir en proportion celle du monde environnant. Pour le dire un peu crûment, dans l'optique beuvienne, l'œuvre est assimilée à un pot-pourri passoire comme cela ressort de cette formule révélatrice :

Si ce n'est pas un traité de géométrie pure, si c'est surtout un ouvrage littéraire, c'està-dire où il entre de tout. (Marcel Proust 1987: 126)

Et ce " tout " qui " entre " dans l'œuvre, finit par intéresser davantage le critique que l'œuvre elle-même. Car l'étude de l'œuvre devient un prétexte à l'étude de l'homme qui la produite. Ainsi, Sainte-Beuve nous entraîne dans une structure circulaire dont la force motrice réside non pas dans l'œuvre et la littérature, mais dans la personne de l'écrivain : juger l'homme permet de juger 
le livre, quant au livre, on ne le lit que pour remonter à l'homme. Cet homme, comme l'exprime sans ambages le critique, on veut : "Etre sûr de le tenir tout entier. » (Marcel Proust 1987: 126)

Pierre Brunel rappelle que Sainte-Beuve cherchait l'homme dans l'écrivain ; les Portraits littéraires dépeignent avant tout des hommes et des époques : en se renseignant sur ces éléments extérieurs, le critique vise à saisir « le tic familier, le sourire révélateur, la gerçure indéfinissable, la ride intime et douloureuse qui se cache en vain sous les cheveux déjà clairsemés » (Sainte-Beuve 1950: 867), et, en dernière instance, par delà l'œuvre, censée être l'objet véritable du critique, c'est l'esprit responsable de sa production qui finit par occuper la première place : "l'analyse disparaît dans la création, le portrait parle, on a trouvé l'homme. " (Sainte-Beuve 1950: 867)

Hippolite Taine, pour sa part, considérera Sainte-Beuve comme un précurseur ayant importé dans l'histoire morale les procédés de l'histoire naturelle et il inventera la science que ce dernier appelait déjà lui-même de ses vœux. Cette science, à travers l'étude des conditions de vie d'un écrivain, aura pour visée de dresser l'inventaire des grandes familles d'esprit et les principales divisions de celles-ci. A travers l'étude des œuvres est menée en réalité une analyse de type botanique ayant pour but de dégager les grands types humains.

La critique que Proust fait de cette méthode est connue. Je rappelle simplement qu'elle repose sur l'idée fondamentale que l'homme social ne coïncide pas avec le moi profond responsable de la production de l'œuvre et qu'il est nécessaire de séparer l'homme de l'œuvre. De même, le milieu n'explique rien, car chaque écrivain doit réinventer "de toutes pièces" (Proust 1987: 127) une vérité personnelle, distincte de la monnaie courante des jugements que l'on émet lorsqu'on est porté par un groupe, une ambiance générale où l'on n'est pas soimême ; c'est sur cette vérité-là qu'il bâtira son œuvre. A partir de là, toute critique véritable se doit de s'appuyer «sur ce qu'il y a de réel et d'indépendant de toute science dans l'art. " (Proust 1987: 124)

Boy remonte-t-il lui aussi à l'homme par delà l'œuvre en laissant celle-ci de côté ? Refuse-t-il de la considérer comme un organisme producteur d'une logique propre, appartenant essentiellement au domaine de l'art ? Se désintéresse-t-il lui aussi du «moi » profond ? Enfin, sa méthode est-elle aussi déterministe et scientifique que celles prônées par ces prédécesseurs positivistes français?

Que Boy s'intéresse à la vie de l'auteur cela ne fait pas de doute, quant au lien entre la vie et l'œuvre il le postule et réclame son exploration sans la moindre ambiguïté. "On ne peut séparer la littérature de la vie » (Boy-Żeleński 1978: 49), écrit-il par exemple ou encore : "l'histoire de la littérature n'existe pas sans le climat, la couleur d'une époque donnée ", car, lorsqu'elle est privée 
de ces éléments, elle " est inéluctablement comme suspendue dans le vide. " (Boy-Żeleński 1978: 49).

Cela dit, même une simple lecture des feuilletons littéraires dédiés à la Jeune Pologne, où le biographisme risque d'apparaitre comme une sorte d'évidence, puisque Boy y parle d'auteurs qu'il a fréquentés personnellement, nous avertit qu'il faut éviter de forger des conclusions hâtives.

Tout d'abord, parce que cet appel à ne pas tenir pour quantité négligeable les petits faits de la vie des écrivains, leur ancrage dans une réalité matérielle et sociale précise, intervient dans une polémique où Boy s'en prend à la posture " à genoux " adoptée face aux écrivains, intervenant d'ailleurs surtout après leur mort, dans laquelle, selon lui, se complaisent ses compatriotes. Lui voudrait qu'on s'intéresse un peu plus aux écrivains quand ils sont en robe de chambre, non juchés sur des socles telles des statues. A la canonisation il préfere ce qu'il appelle le ragot ("plotka »), un terme sur lequel je reviendrai lorsqu'il s'agira de parler du lien à l'oralité postulée par cette critique et qui contribue le plus puissamment à la singulariser.

Pour Boy il s'agit de compenser l'excès de pathos et de sérieux en se référant à l'aspect comique qui se dégage aussi bien de la vie des écrivains, les plaisanteries auxquelles ils se sont adonnés, mais que l'on préfere garder muettes, comme on détruit des documents jugés à tort susceptibles de ternir leur légende. Comme si, ainsi que le dit cette formule révélatrice : « le sourire n'était pas une forme parfaitement naturelle de communion entre les esprits ». (Boy-Żeleński 1978: 51).

L'autre raison pour laquelle le rappel des détails biographiques et contextuels parait utile au critique est tout simplement mémorielle : lui qui a participé à l'aventure de la Bohème fin de siècle ne veut pas que l'oubli s'empare de ce passé, que le temps efface ses traits les plus saillants. Mais cela ne veut pas dire qu'il conteste l'autonomie de la littérature en tant que telle, ni qu'il considère la biographie et le milieu dans lequel a évolué l'écrivain comme responsables de la production de l'œuvre... Son approche est marquée par son ouverture et sa polyvalence : que Boy s'intéresse aux éléments extérieurs au texte ne prouve pas qu'il élève ceux-ci au rang de facteurs déterminants, mais simplement que, pour lui, la littérature s'intègre à un ensemble dont les autres dimensions sont aussi dignes d'intérêt.

Car Boy a parfaitement conscience du caractère parfois inessentiel de la collecte de renseignements biographiques et contextuels. "En effet, si l'exploration minutieuse des éléments qui ont accompagné la venue au monde d'une œuvre donnée, semble être une débauche historico-littéraire inoffensive, il lui arrive en même temps d'être assez stérile » (Boy-Żeleński 1978: 121), écrit-il dans son étude sur Les noces de S. Wyspiański. Néanmoins, il est des cas, précise-t-il 
dans la foulée, où " il faut faire des exceptions ». Cela ne veut pas dire que l'utilisation des renseignements liés à la genèse de l'œuvre, mais qui restent néanmoins extérieurs à elle, doive être réclamée systématiquement, ni même — comme on le verra - qu'elle constitue une clé permettant de déchiffrer le sens véritable de l'œuvre. Il se trouve simplement que dans le cas précis des Noces de Wyspiański, plusieurs facteurs s'associent pour faire de cette exploration une étape importante, qu'il serait dommageable de ne pas entreprendre, quand bien même on continuera à la considérer pour ce qu'elle est, à savoir un travail accompagnant la lecture de l'œuvre.

Ces facteurs s'ordonnent en deux séries dont la seconde entraîne la première. Tout d'abord, il y a le fait que Boy a été le témoin actif de ces circonstances :

[...] aujourd'hui, alors que la tradition orale commence déjà à s'étioler, mais que les acteurs de cette époque restent suffisamment nombreux, sans doute le temps est-il venu que quelqu'un accepte d'accomplir ce que dans le cadre de cette esquisse, je n'ai pas l'ambition bien sûr de réaliser, à savoir rassembler toutes les preuves matérielles permettant de comprendre de façon adéquate les Noces. (Boy-Żeleński 1978: $120-121)$

Mais si, dans le cas des Noces, ces preuves matérielles vont s'avérer utiles, c'est parce que cette pièce elle-même a été conçue d'une façon particulière. Car Wyspiański a tiré la substance de sa pièce de ce que Boy appelle «la réalité effective $^{3}$ ", ce qui veut dire que dans le cas des Noces, c'est la facture même, l'organisation interne de l'œuvre qui entretiennent une relation privilégiée aux circonstances réelles, historiques, ayant accompagné leur éclosion :

Le rapport du poète à la réalité dans les Noces s'écarta de la règle habituelle : l'anecdote ne fut pas un point de départ, mais le matériau le plus essentiel de la création. Rarement une telle occasion nous est donnée de jeter un regard aussi fécond dans l'atelier du poète. (Boy-Żeleński 1978: 121)

Plus loin, Boy écrit que " ce ne sont pas seulement les personnages des Noces qui sont tirés de la réalité mais aussi les détails de l'action » (Boy-Żeleński 1978: 135). De plus, ici comme ailleurs, l'attention portée aux circonstances par définition extérieures à l'œuvre réduit le risque d'analyses tombant dans des généralisations abusives et qui s'intéresseront davantage à ce que Boy nomme l'idéologie tirée de l'œuvre qu'à sa matérialité poétique, c'est-à-dire son organisation formelle concrète, ce qu'un penseur contemporain de la traduction littéraire, Antoine Berman, nomme " la lettre " (Berman 1999) — et qui précisément constitue la ligne de mire du critique polonais.

3 Ce motif est égrené tout au long de l'essai. 
De plus, chez Boy, l'attention aux circonstances extérieures s'allie de manière paradoxale bien que tout à fait logique à la mise en lumière d'une spécificité proprement littéraire des forces engendrant l'œuvre. Déjà, lorsqu'il regrette que son intérêt pour le contexte soit perçu comme un acte sacrilège, Boy écrit :

Le rappel de cette réalité, dont la conscience ne fait qu'augmenter le sentiment d'admiration que j'éprouve pour l'œuvre géniale de Wyspiański et que je considère comme indispensable pour une compréhension adéquate de celle-ci, a semblé constituer pour certains une profanation, une attaque contre son charme etc. (Boy-Żeleński 1978: 48)

Cette phrase, qui vise surtout à dissiper un malentendu montre que, dans l'esprit du critique, l'étude de la réalité sert à mieux mesurer comment l'écrivain, en concevant son œuvre, s'est détaché de celle-ci. Car entre la réalité et l'œuvre géniale Boy perçoit un écart et c'est précisément cet écart qu'il entend mettre en lumière par le rappel des circonstances prosaïques, matérielles de la genèse de l'œuvre. L'étude sur les Noces déjà évoquée, ne laisse aucun doute à ce sujet. On y voit comment une transmutation se réalise de la réalité à l'œuvre géniale, impulsée par le génie poétique, élevé au rang d'une entité autonome et mystérieuse. Au détour d'une phrase, Boy y fait voler en éclats la conviction positiviste selon laquelle c'est au sein de la réalité extérieure qu'il faut chercher les puissances ayant engendré l'œuvre :

On peut supposer que Wyspiański, en s'emparant de la plume, avait pour intention de composer un pamphlet satirique de ses amis; durant le processus d'écriture, le génie de la poésie l'a attrapé par les cheveux et les murs du manoir de Bronowice se sont élargis - tel un nouveau Soplicowo — devenant ainsi le symbole de la Pologne contemporaine. (Boy-Żeleński 1978: 122)

Ainsi, Boy distingue nettement la réalité sociale, collective, les circonstances matérielles, du génie ou de la fantaisie poétiques, responsables de la transfiguration de celle-ci en un objet inattendu, inscrit dans une dimension autre. Et s'il s'intéresse aux éléments extérieurs au texte, c'est pour resituer le texte dans le contexte vivant d'où celui-ci émerge et duquel, précisément, il va se détacher pour acquérir sa spécificité poétique. Or si la pièce de Wyspiański, incarne un type de littérature qui se caractérise par une proximité du texte et de la vie, il n'empêche que le texte obéit à des lois immanentes : il invente une poétique qui entraîne une rupture par rapport à la réalité dont il s'est pourtant inspiré.

Les Noces, écrit Boy plus loin, illustrent:

ce sens de l'observation extrêmement développé que possédait Wyspiański, lequel, à partir du bruissement d'une conversation, était capable de reconstruire la scène 
entière, exactement dans le style des personnes qui y avaient participé, et qui, tout en utilisant ces traits authentiques, les élevait haut dans les contrées de la poésie. (Boy-Żeleński 1978: 132)

La réalité n'exclut donc pas l'autonomie de la poésie, au contraire elle permet de mieux la mettre en valeur. S'il s'avère utile de collecter des informations et autres anecdotes sur les faits entourant la genèse d'une œuvre, c'est parce qu'ainsi est rétabli le lien entre la littérature et la vie même si chaque sphère préserve son autonomie. Mais c'est aussi pour mettre en lumière la façon dont la poésie opère une transmutation des éléments de départ qui lui ont été donnés. Ce jugement, qui nous éclaire tout autant sur les Noces que sur la méthode employée par Boy, le confirme :

que j'aie conscience que cet ouvrage devenu presque aussitôt un symbole est lié de façon très forte à la réalité ne peut que nous le rendre plus vivant, et en même temps rendre ce moment d'émotion unique en son genre que nous éprouvâmes, nous qui étions proches de la naissance des Noces, lorsque nous vîmes quasiment sous nos yeux s'opérer cette miraculeuse transsubstantiation de la vie en art, en poésie. (Boy-Żeleński 1978: 138)

Ainsi, que Boy s'intéresse à la vie de l'auteur cela ne fait pas de doute, mais gardons-nous d'en conclure hâtivement qu'il considère la biographie et le milieu dans lequel a évolué l'écrivain comme une clé qui expliquerait tout, en particulier le mystère de l'art, et qui autoriserait à faire l'impasse sur une étude de la poétique immanente des œuvres. Boy ne fait jamais dériver directement l'œuvre de ces circonstances extérieures, c'est-à-dire de l'homme, de sa biographie et du milieu dont celui-ci faisait partie.

\section{Des niveaux contradictoires qui coexistent}

De plus, sa critique ne se place pas sous l'obédience exclusive de la science. Les méthodes scientifiques, en particulier lorsqu'il s'agit de trouver des preuves matérielles (" materialy rzeczowe») (Boy-Żeleński 1978: 121), elle ne se prive pas de les utiliser, mais elle se veut surtout impliquée, participative, idiosyncrasique à l'occasion, et sensible, par quoi elle s'éloigne et s'émancipe du modèle positiviste. D'une façon générale, on remarquera que Boy enquête sur la réalité précisément pour mettre en lumière l'écart qui sépare l'homme, la vie de l'œuvre : un écart qu'il met en avant aussi bien dans le cas d'un Stanisław Przybyszewski que dans celui d'Henri Beyle dont la vie semble contredire ce que laisserait supposer celle d'un Stendhal.

Ces disparités, ces antinomies pourrait-on dire, ces discordances interviennent entre plusieurs niveaux de personnalité, des tranches de vie qui coexistent de 
manière contradictoire chez le même individu. Finalement, il semblerait qu'aussi bien par rapport à lui-même qu'aux écrivains, Boy adhère à une conception extrêmement moderne, axée sur le clivage interne, l'éclatement du moi et de la vie, laquelle tranche nettement avec le schéma déterministe fondé sur la continuité des causes et des effets propre au positivisme. La vie ne se laisse pas réduire à la science, elle déborde de tous côtés ses catégories univoques — de plus, elle manifeste des tensions, des contradictions entre ses différentes sphères.

Par exemple, alors que l'œuvre littéraire de Stanisław Przybyszewski ne connaît que le pathos et le dithyrambe, sa vie, qui était triste et tragique, contient, ainsi que le principal intéressé en est convaincu lui-même, une dimension profondément comique, et c'est la raison pour laquelle Przybyszewski lègue à l'humoriste qu'est selon lui Boy la tâche d'écrire à l'avenir l'histoire de la Bohème de Cracovie. Car lui seul sera capable de montrer que cette vie tragique était aussi une farce macabre. Bien sûr, il ne s'agit pas de le prouver par des moyens scientifiques, mais d'user d'une sensibilité particulière, capable de déceler le potentiel comique contenu dans ce qui passe pour avoir été la réalité de cet épisode de la vie culturelle de la Pologne d'alors.

De même, dans l'étude sur Bernardin de Saint-Pierre, auteur français du XVIII siècle qu'il n'a donc pas pu connaittre, Boy insiste sur la distance qui sépare le modeste fils d'un fonctionnaire de la poste, qui sa vie durant a accablé les ministères de ses doléances financières, et l'extraordinaire peintre de la nature, qui invente un langage capable de rendre de manière concrète ce que l'œil et non la pensée voit ${ }^{4}$.

Boy recourt aussi à l'antinomie quand il s'agit de se présenter soi-même, et il évoque, non sans une pointe de malice, d'un côté le bourreau de travail, traducteur infatigable des chefs-d'œuvre de la littérature française vers le polonais, de l'autre - le poète paresseux et bon vivant, sybarite et voluptueux.

A cela ajoutons que cette conscience aiguë des disparités déstructurant et structurant à la fois les vies humaines conduit le critique vers une conception de la littérature qui, dans le prolongement de ses remarques sur le génie poétique, fait d'elle une structure parallèle à la réalité se mouvant selon une logique parfaitement immanente, engendrée par le royaume de l'art, non celui de la vie. Ecoutons à ce propos la façon dont Boy conçoit la littérature française :

La littérature française est peut-être la seule où tout se tient par les mains et reste lié sur quatre siècles au moins : impossible de bien la comprendre si on ne la connaît pas dans son entier, au moins à travers ses manifestations les plus typiques. (Boy-Żeleński 1978: 38)

4 Voir Szkice o literaturze francuskiej [« Etudes sur la littérature française »] (Boy-Żeleński 1956 : 143-160). 
Létude sur Stendhal ${ }^{5}$ est révélatrice à cet égard. Certes, Boy rappelle d'abord dans ses grands traits la vie de l'écrivain avant de se demander quel fut le caractère de l'homme. Mais, très vite, il en vient à enquêter sur la dette des mouvements fraîchement éclos à l'égard de l'auteur du Rouge et le noir : Zola, Bourget, soit des conceptions très opposées qui toutes se réclament pourtant de Stendhal, chacune selon un autre biais. A ce moment-là, Boy aborde la question de l'œuvre. Il analyse celle-ci en tant qu'entité dotée d'une structure et d'une dynamique propres. D'abord sous l'angle du roman social autour du pivot que constitue un héros, porte-parole du peuple, Julien Sorel et son «fanatisme de l'honneur ». Or que se passe-t-il ? Boy voit-il dans ce personnage un reflet déformé, idéalisé ou tout simplement transposé de l'auteur, Henri Beyle devenu Stendhal ? En aucune façon. Ce qui intéresse le critique est la dynamique propre, autonome, structuraliste avant la lettre, du roman français en tant qu'il élabore son évolution autour de cette figure d'hommes du peuple : Julien Sorel apparaît comme la résultante d'une longue évolution partant de Jacques le fataliste et dont le maillon intermédiaire s'est appelé Figaro. Boy rappelle qu'alors que Figaro avait pour lui le talent, l'énergie, l'intelligence et le cœur, il était dépourvu de dignité sociale, puisqu'il n'était encore que le valet de son maitre et donc le lointain cousin du vilain des fabliaux et des anciennes comédies. C'est sous cet angle que Boy mesure l'originalité de Stendhal ayant conféré à son héros, jeune homme issu lui aussi du peuple, un sentiment de sa propre dignité paroxystique, ce qui le rend capable de toutes les folies, y compris de commettre un meurtre.

Ensuite Boy passe à l'analyse du second aspect structurellement déterminant selon lui : l'amour. Ici on voit poindre la possibilité d'une transposition entre l'homme et l'œuvre, car — comme le rappelle le critique — l'amour était la principale préoccupation de Stendhal. Doit-on par conséquent chercher à expliquer Julien Sorel par les expériences de l'auteur en la matière ? Eh bien, détromponsnous : certes Boy indique la pertinence du lien s'établissant entre la fiction et la vie de ce point de vue, mais il se garde soigneusement de tirer entièrement Julien Sorel du côté de la biographie de son auteur. Sa démarche est autrement plus subtile, car elle est au moins double. D'une part, Boy souligne la position qu'occupe Julien dans une galerie d'êtres de papier déjà produits ou allant être produits par la littérature : cet enfant du plaisir annonce Bel-ami et, surtout au cours de l'épisode du séjour au Palais de Mole, il évoque le Valmont des Liaisons dangereuses tout en semblant être un avatar des favoris et des courtisans des époques passées.

5 Dans Stendhal i Balzac (Boy-Żeleński 1958 ; voir en particulier les pages 7 à 50, la perspective comparatiste évoquée dans les lignes suivantes de cet article se trouve p. 23). 
Et, dernière estocade portée à une conception biunivoque par laquelle la littérature est amenée à n'être qu'un simple reflet de la vie : si Stendhal représente les mécanismes d'ascension sociale d'un façon aussi abstraite, idéalisée et donc improbable, c'est parce que sa conception du roman est tributaire du XVIII ${ }^{e}$ siècle et n'a pas encore été fécondée, et pour cause, par le roman balzacien : Balzac, lui, saura que l'amour d'un plébéien, d'un homme du travail, emprunte d'autres voies, que les individus subissent l'influence de la grande ville, ce que l'épisode du Palais de la Mole, bien que se déroulant à Paris, ne laisse même pas pressentir. Or la révolution balzacienne qui pointe déjà le bout du nez va bouleverser les modes de représentation littéraire. Désormais, qu'un jeune précepteur à peine dégrossi puisse devenir le gérant efficace de l'une des plus grosses fortunes de France semblera une improbabilité. Chez Balzac, l'enjeu se trouve ailleurs. Il n'empêche, ajoute Boy, comparé à Stendhal, Balzac même s'il connaît à fond les arcanes des mécanismes sociaux, les rouages incarnés par ces hordes d'avocats, de courtiers, de notaires dont ses romans font entendre le grondement, semble presque plat. Balzac auquel pourtant Boy voue une véritable adoration.

\section{Une critique littéraire nourrie par l'oralité}

J'en viens ainsi à la dernière partie où j'entends montrer que ce qui fait l'originalité de la critique telle qu'elle est pratiquée par Boy et qui en même temps contribue à la rendre moderne tout en lui conférant cet air d'éternelle jeunesse, est la conception que Boy se fait du texte littéraire, lequel est par définition écrit, mais qui, pour lui, ne laisse pas de plonger ses racines dans une préhistoire marquée par son oralité originelle vivante.

J'ai été surpris de remarquer à quel point Boy se montre sensible à la double sphère des sons et de l'oralité vivante originelle. C'est de là sans doute que lui vient cet intérêt connexe pour le bouillonnement des échanges interhumains car celui-ci est propice à l'affleurement d'un discours oral fécondant. Ces écrits regorgent de passages rapportant ce qui se disait quelque part, ce qui s'est dit. Dans les appartements où la Bohème se retrouvait, ses cafés, au cours des promenades nocturnes à travers la ville. Tout cela, le texte le dit, en usant abondamment du style direct, en rapportant des anecdotes. C'est que, pour Boy, le mot vivant, le mot qui fuse dans les contacts directs constitue une force qui féconde l'esprit.

Boy écrit de telle sorte que quelque chose des éclats de cette oralité originelle, et, plus largement, de la sphère des formes acoustiques, à laquelle le critique se montre extrêmement sensible, transparaisse dans son texte. Qu'il s'agisse des sons d'instruments de musique, d'échos et de bruits divers, des paroles prononcées à l'occasion de discussions menées à bâtons rompus ou de répliques brillantes, 
toute cette sphère du son et de l'oralité irrigue en profondeur le texte du critique. A cet égard, les écrits critiques portent la marque visible d'une éducation de l'oreille à laquelle Boy s'est livré lui-même et à laquelle il convie à présent son lecteur. Ainsi le texte remplit une fonction de double transmission : dépositaire de la réalité vivante du passé, il transmet, à son tour, cette réalité à ses lecteurs, mais aussi à ses auditeurs directs, car Boy entreprend de faire déborder la compréhension intime qu'il a acquise des textes sur un public auprès duquel il se rend physiquement, sillonnant la Pologne en long en large et en travers, pour y donner des conférences, ce qu'il rapporte lui-même, comme lors de la tournée qu'il consacre à François Villon.

C'est que l'esquisse littéraire ne doit pas être faite seulement de mots qui s'engendrent eux-mêmes, dans une coupure nette avec la réalité, ce qui - comme l'écrit James Walter Ong - constitue la marque distinctive du discours écrit par rapport au discours oral. A travers le texte de Boy, retentit la symphonie des puissances acoustiques fécondantes, séminales ayant jadis donné vie et souffle aux relations interhumaines qu'il évoque.

Parler d'un auteur signifie pour lui évoquer le bouillonnement verbal ayant accompagné physiquement la production des œuvres, c'est-à-dire l'oralité de la place publique et celles des intérieurs grouillant de monde où se rencontrait la Bohème littéraire de Cracovie. Ainsi, le texte critique n'est pas clos sur lui-même, mais charrie avec soi les échos et les éclats oraux de toute cette époque, véhicule cette fois-ci, peut-être, d'une sorte de genius loci.

A un premier niveau, le son vivant constitue un élément physique, sensible qui permet de se sentir plus proche de l'œuvre. Or Boy veut pratiquer une critique fondée sur la proximité tout autant que la distance critique. Cette proximité avec l'œuvre, nous la découvrons d'abord à l'occasion du rappel de la découverte de Paris où Boy nous raconte comment étourdi par la richesse sensible et spirituelle de la métropole, il décide finalement de s'enfermer dans la chambre de son petit hôtel et d'y passer ses journées entières, couché dans le lit et plongé dans la lecture de la totalité de la Comédie humaine (Boy-Żeleński 1978: 30-31). Cette expérience repose sur la proximité, car Boy lit Balzac à Paris tandis que son enfermement dans la chambre d'hôtel n'est que partiel, puisqu'à travers la fenêtre, de la rue avoisinante, lui parviennent les échos de la ville. Plus tard, cette proximité, Boy la réinventera en décidant de recréer dans son cabinet ainsi qu'il le dit luimême une France artificielle par le biais de la traduction des chefs d'œuvre de la littérature française. Et le premier auteur traduit sera Balzac.

Une autre expérience auditive initiatrice, elle aussi parisienne, résultera de la découverte d'un cabaret parisien fréquenté essentiellement par un public autochtone, «Le Grillon » où il peut entendre des mélodies à la fois simples et porteuses 
des tentations charriée par la vie parisienne chantées par Paul Delmet, Gabriel Montoya ou Numa Blès ${ }^{6}$.

Cette soirée est à l'origine d'une émotion et d'un sentiment esthétiques durables et profonds chez le critique. Pour désigner ces phénomènes Boy parle de fluide, ailleurs de télépathie. Certaines formes sensibles, en particulier acoustiques, possèdent chez lui la capacité de dilater l'esprit, de faire éclater les carcans qui l'enserrent, élargissent son champ de rayonnement, ses facultés sensibles. Grâce à elle, le sujet neurasthénique surmonte sa mélancolie et reconquiert la capacité de transmuer la réalité.

Aussi, n'est-on pas surpris de voir que même lorsqu'il analyse des textes écrits, proprement littéraires, il ne perd pas de vue le lien que ces textes peuvent préserver avec une oralité originelle. Ainsi, dans son étude sur Bernardin de Saint-Pierre, le thème de la bonté supposée innée de l'homme est assimilé à une "chanson " (Boy-Żeleński 1956: 153). De même, Boy écrit que c'est à l'auteur de Paul et Virginie que l'on doit le plus bel hymne en l'honneur des femmes qu'un homme ait jamais " chanté " par le biais de la littérature.

Cela prouve sous un autre angle que Boy ne conçoit pas la littérature sur le mode d'une coupure avec la vie : il l'envisage comme une création souveraine autonome qui tout en obéissant à des lois appartenant au domaine de l'art, distinct de la réalité, n'émerge qu'à travers une lutte devant rester à jamais mystérieuse que le poète livre surtout avec lui-même, mais aussi avec son milieu, avec la réalité sociale, physique avec laquelle il est en prise.

Ainsi, les esquisses littéraires de Boy, en particulier celles relatives à la Jeune Pologne, regorgent de passages où affleure une oralité débridée et fécondante. Je me contente de citer quelques exemples. Dans les évocations du personnage de Stanisław Przybyszewski, on relèvera la permanence et la variabilité du paradigme sonore et musical. Tout d'abord, il est dit que le bouillonnement artistique cracovien a été préparé par ce que les jeunes gens «tendaient l'oreille aux échos venus d'Europe » (Boy-Żeleński 1978: 55). Ensuite, sont évoquées les discussions endiablées menées dans les cafés : ce déferlement oral s'explique par le fait que le débat d'idées "remplaçait pour une part le football et la boxe " (Boy-Żeleński 1978: 57), car à l'époque, le sport restait un phénomène à découvrir. Enfin, l'attention du critique se concentre sur Stanisław Przybyszewski, et à partir de là, instantanément, le lecteur est convié à rejoindre un univers à dominante sonore. Ainsi, Przybyszewski est-il représenté en train de frapper les touches d'un piano, quant aux beuveries de la bohème, elles ont lieu dans un magasin de pianos à queue où ceux-ci sont rangés par dizaines. Les fenêtres sont ouvertes et

\footnotetext{
${ }^{6}$ Voir Mózg i pteć [" Le cerveau et le sexe »] (Boy-Żeleński 1957 : 25-30).
} 
la musique coule au loin vers la place du marché et jusqu'aux tertres de Krakus et de Wanda qui s'élèvent à la périphérie de la ville. La polonaise de Chopin se marie à l'appel du clairon de l'Eglise Sainte-Marie. "Il est révélateur, écrit Boy, que le premier meuble qu'eut possédé Przybyszewski fût un piano à queue " (Boy-Żeleński 1978: 70). A un autre moment, on entend, durant des heures, le jeune médecin Szyszka jouer du violon. Il interprète la mélodie de Moniuszko "Connais-tu ce pays ? » et lorsque la fatigue le prend ou lorsqu'elle s'empare du maître, alors c'est Stasinek Sieroslawski qui prend le relais. Par ailleurs, Przybyszewski est moins évoqué dans une posture d'écrivain, que dans celle d'un discutant infernal qui n'a de cesse de faire éclater un rire sarcastique, en particulier lorsqu'on vient lui parler littérature, car :

il méprisait tout ce qui relevait d'un langage de l'intellect, tout ce qui affichait la prétention à être de la pensée à ces moments où il se contentait de refléter ces rayons ultraviolets. Le bruit des mots seulement, un bruit répété sans discontinuer telle une phrase musicale, un mot élevé à la dignité d'une épigraphe pour l'alcool. Car Stach ne buvait jamais sans recourir à une épigraphe. (Boy-Żeleński 1978: 74-78)

Ce même Szyszka est le personnage principal d'une anecdote qui illustre la fonction séminale du mot-slogan :

je me souviens d'une épigraphe qui s'était collée à nous pour longtemps. Szyszka revenait d'un manoir où le propriétaire était paralysé et son épouse gravement malade. Szyszka devait surveiller la comtesse tandis que le comte, devenu un vieux croûton, se faisait assister par un valet qui ne le quittait pas une seconde, Joseph, sans lequel il n’aurait pas pu se débrouiller dans les situations les plus banales. Un jour, des cris éclatèrent dans la maison, tout le personnel se précipita dans la chambre de Madame. Szyszka déboule en annonçant : "Monsieur le Comte, madame la Comtesse agonise. » Sur ce, le comte lui répond d'une voix irritée et impuissante : "C'est pon! C’est pon! mais moi, je me suis chié dessus, et Joseph qui n'était pas là, n'est toujours pas là. » Przybyszewski est devenu fou de cette exclamation : "C'est pon! C'est pon!" Pendant un temps, on vida cul-sec tous les verres à ce signal : "C'est pon! C'est pon »! (Boy-Żeleński 1978: 79)

Enfin, la vie de Przybyszewski est comparée à une sonate où l'épisode cracovien fait office de scherzo.

De même, l'essai intitulé de façon révélatrice, marquée par l'oralité, " " un ragot " concernant Les Noces de Wyspiański » est entièrement traversé de références à l'oralité. Certaines en occupent l'arrière-plan comme les évocations des mots d'ordre " couleur ", "lumière ", "plein air " qui bruissent tels des slogans révolutionnaires, des vieilles mélodies polonaises improvisées par Włodzimierz Tetmajer, ou encore l'incontinence bavarde proverbiale du poète Lucjan Rydel 
à propos de laquelle Boy cite une antienne née sur le pavé varsovien fondée sur la répétition monotone du prédicat lui-même redoublé : «bavarde, bavarde ». Mais c'est le point central de cet essai qui insère le texte écrit dans une dimension à la fois sonore et orale. Il s'agit du moment où Boy évoque la façon dont Wyspiański se tint debout durant toute la durée de la noce, plongé dans l'écoute des bruits et des sons qui retentissaient tout autour :

Je me souviens de lui comme si cela avait lieu aujourd'hui, lorsque, sa redingote noire boutonnée jusqu'au cou il se tint toute la nuit debout contre le chambranle de la porte, en regardant de ses yeux d'acier extraordinaires. Tout autour la noce battait son plein, les danses bourdonnaient et sans cesse des groupes de plusieurs personnes entraient dans la pièce, sans cesse à ses oreilles parvenaient les lambeaux d'une conversation. Et c'est là-bas qu'il aperçut et entendit sa pièce. (Boy-Żeleński 1978: 129)

Quant à Boy lui-même, par delà les nombreux passages au style direct, il émaille son propre texte, narratif et argumentatif, de formules caractéristiques du discours oral. Que ce soient des apophtegmes : "La littérature ne doit pas être isolée de la vie » (Boy-Żeleński 1978: 49), des adages "Une histoire sans anecdotes, c'est de la cuisine sans sel " (Boy-Żeleński 1978: 51) ou encore des formules sapientiales "Les amants des dieux meurent jeunes " (Boy-Żeleński 1978: 60), toutes ces constructions adoptent une modalité fortement expressive, ce qui se traduit par l'usage répété du point d'exclamation comme dans la sentence métadiscursive et auto-référentielle : "L'individualisme, voilà un slogan!» (Boy-Żeleński 1978: 55).

La logique de Boy n'est donc ni binaire ni fusionnelle ; elle est critique, c'està-dire diérétique, analytique et plurielle, elle alterne les points de vue et établit des séparations mais de façon à les réunir en un tableau vivant où elles continuent à exister séparément tout en laissant apparaître une dynamique d'ensemble. Cette pluralité que Boy dégage dans ses esquisses vise à produire un jugement critique qui jamais n’apparaîtra comme la résultante mécanique des observations collectées, mais qui, quoi qu'il arrive, vise à dégager la dynamique propre de l'œuvre, fruit de forces relevant du processus de développement de l'art lui-même...

\section{BIBLIOGRAFIA}

Berman Antoine. 1999. La traduction ou la lettre ou l'auberge du lointain. Paris: Éditions du Seuil.

Boy-Żeleński Tadeusz. 1956. Szkice o literaturze francuskiej. Warszawa: Państwowy Instytut Wydawniczy.

Boy-Żeleński Tadeusz. 1957. Mózg i pteć. Warszawa: Państwowy Instytut Wydawniczy. 
Boy-Żeleński Tadeusz. 1958. Stendhal i Balzac. Warszawa: Państwowy Instytut Wydawniczy.

Boy-Żeleński Tadeusz. 1978. Reflektorem $w$ mrok. Warszawa: Państwowy Instytut Wydawniczy.

Ong James Walter. 2009. Osoba, świadomość, komunikacja, antologia. Warszawa: Wydawnictwo Uniwersytetu Warszawskiego.

Ong James Walter. 2011. Oralność i piśmienność. Warszawa: Wydawnictwo Uniwersytetu Warszawskiego.

Proust Marcel. 1987. Contre Sainte-Beuve. Paris: Gallimard. Folio essais.

Sainte-Beuve Charles-Augustin. 1950. CEuvres, T. 1. Paris: Gallimard, La Pléaide.

\title{
Piotr Bitos
}

\section{TADEUSZ BOY-ŻELEŃSKI: A LITERARY CRITICISM COMMITTED TO THE EXPLORATION OF LIFE AND THE AUTONOMY OF ART}

\author{
(summary)
}

The aim of this article is to demonstrate how the Polish literary critic and translator Tadeusz Boy-Żeleński achieved two contrasting goals in his work. The author shows how important the context, external to the ground of the literary work itself, is for Boy, (and he reflects on the specific reasons why Boy adopts this attitude), while also describing the way Boy refuses simultaneously to consider it as a clue which could allow us to decode the meaning and deeper senses of a literary work. Moreover, Boy emphasizes the means great writers used to invent in order to transform reality in his own art and to insert the figures they created into an immanent dynamic evolution of literary patterns.

The author sets forth a thesis that Boy's method of digging out the genuine form of the works he analysed was due to the careful attention he gave to the oral and, more broadly, the sonic dimension of human experience, which to him was a source of constant fertilization. At the same time, the article explores the way this sensibility to sounds was deeply rooted in Boy's direct life experiences — his relationship both to Paris and to the modernist literary movement called Young Poland "Młoda Polska" led by such outstanding figures as Stanisław Przybyszewski and Stanisław Wyspiański with whom Boy frequented Cracow's various cafés and theatres as a young man.

\section{KEYWORDS}

Żeleński Tadeusz (Boy); literary criticism; immanent criticism; orality 



\section{NOTKI O AUTORACH}

Monika Bednarczuk - doktor habilitowany, literaturoznawca. Obecnie wykłada w Instytucie Slawistyki Uniwersytetu w Bochum. Główne obszary jej badań to: kultura w polu wpływów polityki (antysemityzm, konserwatyzm i nacjonalizm w publicystyce i literaturze), konstelacje genderowe, pisarstwo kobiet oraz transfer kultury i nauki na przełomie wieku XVIII i XIX. Autorka monografii: Obraz hiszpańskiej wojny domowej lat 1936-1939 w piśmiennictwie polskim (2008) i Kobiety w kręgu prawicy międzywojennej: idee, sylwetki, strategie pisarskie (2012) oraz artykułów poświęconych kobietom pióra, relacjom polsko-niemieckim i polsko-żydowskim, polskiej percepcji Ukrainy, Bałkanów, Kaukazu i Rosji oraz Uniwersytetowi Wileńskiemu w XIX wieku i jego absolwentom. Współautorka książki Znani, Nieznani, Nierozpoznani (z Ewą Pogonowską, 2009) oraz syntezy Estetyka dyskursu nacjonalistycznego w Polsce 1926-1939 (red. Ulrich Schmid, 2014).

Laurent Béghin - doktor nauk humanistycznych Uniwersytetu w Louvain (l'Université catholique de Louvain, Louvain-la-Neuve). Autor licznych publikacji na temat recepcji literatury słowiańskiej we Włoszech, m.in. Da Gobetti a Ginzburg. Diffusione e ricezione della letteratura russa nella Torino del primo dopoguerra (Bruxelles-Rome 2007); Slavia. Catalogo storico [współpraca: Francesca Rocci] (Turin 2009) oraz książki poświęconej poecie, powieściopisarzowi i tłumaczowi belgijskiemu Robertowi Vivier - Robert Vivier ou la religion de la vie (Bruxelles, 2013). Wykładowca języka i kultury włoskiej na uniwersytetach belgijskich: l'Université Saint-Louis Bruxelles, l'Université Catholique de Louvain.

Piotr Biłos - doktor habilitowany profesor INALCO, kieruje polską sekcją w Institut National des Langues et Civilisations Orientales INALCO (Instytut Języków i Cywilizacji Wschodnich) w Paryżu, gdzie również wykłada teorię literatury i jest współodpowiedzialny za katedrę studiów translatologicznych. Dzieciństwo spędził w Polsce, Algierii i Maroku. Autor książek Exil et modernité: vers une littérature conçue à l'échelle du monde (Wygnanie a nowoczesność - ku 
literaturze w skali światowej) oraz Les jeux $d u$,je”, construction et déconstruction du récit romanesque chez Wiestaw Myśliwski (Gry z „ja" - konstrukcja i dekonstrukcja $w$ fabule powieściowej Wiestawa Myśliwskiego). W Polsce ukazały się jego Powieściowe światy Wiestawa Myśliwskiego, Znak, Kraków 2017.

Cécile Bocianowski - jest asystentką na Wolnym Uniwersytecie w Brukseli (Wydział Języków i Literatur). Obroniła na Sorbonie doktorat poświęcony dwudziestowiecznym europejskim dramaturgom groteski. Zajmuje się literaturą polską i frankofońską w perspektywie komparatystycznej, związkami między literaturą a sztuką oraz translatologią (specjalizuje się w tłumaczeniach z języka polskiego na język francuski). Opublikowała francuski przekład sztuki Nasza klasa Tadeusza Słobodzianka, współredagowała dwujęzyczny tom La Morale de Madame Dulska wydany przez Wydział Polonistyki Uniwersytetu Warszawskiego.

Małgorzata Domagalska - doktor habilitowany, pracuje w Zakładzie Literatury Pozytywizmu i Młodej Polski UŁ. Autorka dwóch monografii: Antysemityzm dla inteligencji? Kwestia żydowska w publicystyce Adolfa Nowaczyńskiego na tamach „Myśli Narodowej” 1921-1934 i „Prosto z mostu” 1935-1939 oraz Zatrute ziarno. Proza antysemicka na tamach "Roli” (1883-1912). W swoich badaniach zajmuje się przede wszystkim problematyką relacji polsko-żydowskich.

Maria Gołębiewska - profesor nadzwyczajny w Zespole Filozofii Kultury Instytutu Filozofii i Socjologii PAN; zainteresowania badawcze - filozofia współczesna (fenomenologia, filozofia egzystencji, strukturalizm i poststrukturalizm), nowożytne źródła filozofii współczesnej, zagadnienia teoriopoznawcze, językoznawcze i aksjologiczne; obecnie zajmuje się szczegółowo problematyką receptywności i performatywności, rozpatrywaną w odwołaniu do fenomenologii. Wybrane publikacje — książki: Między wątpieniem a pewnością. O związkach jezyka $i$ racjonalności $w$ filozofii poststrukturalizmu (Kraków 2003); Demontaż atrakcji. O estetyce audiowizualności (Gdańsk 2003); Rzeczywistość i przedstawienie. O tezach filozoficznych Karola Irzykowskiego (Warszawa 2006); Wiedza egzystencjalna. O trzech koncepcjach poznania w filozofii egzystencji (Warszawa 2008); L’homme démocratique. Perspectives de recherche, red. Maria Gołębiewska, Andrzej Leder, Paul Zawadzki (Frankfurt am Main 2014).

Lidia Ignaczak - pracownik Zakładu Literatury i Tradycji Romantyzmu Instytutu Filologii Polskiej UŁ. Prowadzi badania interdyscyplinarne dotyczące rozpoznawania związków między literaturą i muzyką w konkretnych scenicznych realizacjach, sposobów funkcjonowania form słowno-muzycznych w teatrze 
XVIII-XX wieku, możliwości partyturowego zapisu projektów spektaklu i rejestrowania kolejnych jego realizacji; podobieństw i różnic w wykorzystaniu materiału literackiego w obrazku śpiewającym, wodewilu, operetce, śpiewogrze, operze, widowisku kabaretowym. Jest autorką monografii pt. W podróży po Szpargalii. Palimpsestowe czytanie śpiewników teatralnych Józefa Cybulskiego (Łódź 2007) oraz prac komparatystycznych z dziedziny dramatu i teatru, np.: „Na przyczepkę", czyli Konstantego Ildefonsa Gatczyńskiego przygody z kabaretem („Prace Polonistyczne”, seria LXVII, 2012); Drogi ku świętości. Dzieje Tomasza Becketa $w$ dramaturgicznej interpretacji Thomasa Stearnsa Eliota i Jeana Anouilha (w: Dramat $w$ historii. Historia $w$ dramacie, pod red. K. Latawiec, R. Stachury-Lupy, J. Waligóry, przy współprac. E. Łubieniewskiej, Kraków 2009); Teatralne Boyowanie (1). Miejsce francuskiej farsy $w$ polskim teatrze międzywojennym z perspektywy recenzenta - Tadeusza Żeleńskiego (Boya) („Prace Polonistyczne”, seria LXX, 2015); Tęsknota za Chat Noir i Mirliton. Wokót legendy paryskich kabaretów, pod red. K. Badowskiej i K. Kołodziej. „Acta Universitatis Lodziensis. Folia Litteraria Polonica” 3(33), 2016.

Stanisław Jasionowicz — doktor habilitowany, profesor Uniwersytetu Pedagogicznego w Krakowie. Pracownik Instytutu Neofilologii UP w Krakowie, kierownik Pracowni Badań Porównawczych nad Współczesną Kulturą Zachodnią. Autor dwóch monografii (Roland Barthes - Gilbert Durand. Wizje pluralizmu kultury, Kraków 1999; Pustka we wspótczesnym doświadczeniu poetyckim, Kraków 2009) oraz kilkudziesięciu publikacji w języku polskim, francuskim i angielskim o tematyce literaturoznawczej, ujmowanej często w kontekście komparatystycznym, także w odniesieniu do sztuki współczesnej. Autor przekładów poezji francuskiej na język polski i poezji polskiej na język francuski. Zainteresowania badawcze: teorie wyobraźni twórczej, komparatystyka literacka oraz transdyscyplinarna, europejska i amerykańska poezja nowoczesna (XIX-XXI wiek), literatura podróżnicza.

Marzena Karwowska - doktor habilitowany nauk humanistycznych, literaturoznawca, pracownik Uniwersytetu Łódzkiego (Zakład Literatury Polskiej XX i XXI wieku). Prowadzi badania z zakresu mitokrytyki i antropologii wyobraźni twórczej. Autorka książek: Prapamięć uśpiona. Świat wyobrażeń Bolestawa Leśmiana, Warszawa 2008; Symbole Apokalipsy. Studia z antropologii wyobraźni, Warszawa 2011; Antropologia wyobraźni twórczej w badaniach literackich. Świat wyobrażony Brunona Schulza, Łódź 2015.

Magdalena Lubelska-Renouf - doktor literatury polskiej (Sorbona - Paris 4), professeur agrégée du polonais. Wykładała na uniwersytecie w Caen, w Lille 3, 
aktualnie jest zatrudniona jako pracownik naukowy na Sorbonie (Paris 4). Prowadzi badania nad polską poezją współczesną w perspektywie komparatystycznej. Opublikowała wiele artykułów na ten temat w czasopismach polskich i międzynarodowych. Autorka książki Czestaw Mitosz en quête du réel i tomiku poetyckiego Stany ptywania.

Dorota Samborska-Kukuć - profesor doktor habilitowany, UŁ; historyk literatury wieku XIX; zajmuje się przede wszystkim zjawiskami heterogenicznymi pogranicza na dawnych kresach Rzeczypospolitej, autorka kilku książek i kilkudziesięciu artykułów naukowych o tej tematyce.

Marta Szymor-Rólczak - doktor nauk humanistycznych, literaturoznawca i edytor, adiunkt w Pracowni Edytorstwa Uniwersytetu Łódzkiego. Prowadzi badania z zakresu literatury XVIII wieku i jej związków z paremią, literackiej ramy wydawniczej, a także nad liberackością dzieł literackich oraz współczesnym rynkiem wydawniczym. Opublikowała m.in.: edycję F. Zabłocki, Wybór poezji (Łódź 2010); monografie pod red. przy współudziale M. Poradeckiego Wtadca, wtadza. Literackie doświadczenia Europejczyków od antyku po wiek XIX, (Łódź 2011); Wtadca, wtadza. Literackie doświadczenia Europejczyków. Wiek XX i XXI (Łódź 2011). Wykonawca zbiorowego projektu badawczego „Czytanie poetów polskiego oświecenia. Krasicki - Naruszewicz — Trembecki — Karpiński” zatwierdzonego przez MNiSW w ramach konkursu Narodowego Programu Rozwoju Humanistyki pod kierunkiem dr hab. Bożeny Mazurek. 